\title{
Remains in Peace: American Military Remains and Memory Diplomacy in France, 1918-1972
}

Richard A. Hulver

Follow this and additional works at: https://researchrepository.wvu.edu/etd

\section{Recommended Citation}

Hulver, Richard A., "Remains in Peace: American Military Remains and Memory Diplomacy in France, 1918-1972" (2015). Graduate Theses, Dissertations, and Problem Reports. 5837.

https://researchrepository.wvu.edu/etd/5837

This Dissertation is protected by copyright and/or related rights. It has been brought to you by the The Research Repository @ WVU with permission from the rights-holder(s). You are free to use this Dissertation in any way that is permitted by the copyright and related rights legislation that applies to your use. For other uses you must obtain permission from the rights-holder(s) directly, unless additional rights are indicated by a Creative Commons license in the record and/ or on the work itself. This Dissertation has been accepted for inclusion in WVU Graduate Theses, Dissertations, and Problem Reports collection by an authorized administrator of The Research Repository @ WVU.

For more information, please contact researchrepository@mail.wvu.edu. 
Remains in Peace: American Military Remains and Memory Diplomacy in France, 1918-1972

\author{
Richard A. Hulver
}

Dissertation submitted to the Eberly College of Arts and Sciences at West Virginia University in partial fulfillment of the requirements for the degree of
Doctor of Philosophy in History

\author{
James Siekmeier, Ph.D., Co-Chair \\ Joshua Arthurs, Ph.D., Co-Chair \\ Melissa Bingmann, PhD. \\ Jason Phillips, Ph.D. \\ Kurt Piehler, Ph.D.
}

Department of History

Morgantown, West Virginia 2015

Keywords: American Battle Monuments Commission, War Remains, World War I, World War II, Collective Memory, $2^{\text {th }}$ Century FrancoAmerican Relations, Anti-Americanism, Graves Registration Service, Memory Diplomacy, American Military Cemeteries 


\title{
ABSTRACT \\ Remains in Peace: American Military Remains and Memory Diplomacy in France, 1918-1972
}

\section{Richard A. Hulver}

\begin{abstract}
Although often not viewed as such, a nation's collective memory has use in international relations. The United States left some one-hundred thousand military remains interred in European soil following World War I and World War II, the majority of these in France. Instead of resting in a symbolic void, the memory of American military dead abroad became a means for the living to articulate contemporary foreign policy goals. Elements of the American war memory abroad remained consistent through the twentieth century: sacrifice for a free Europe, fear of radicalized revolutions, and Franco-American friendship. Yet, beneath the formulaic memory lingered evolving motives for remembering. The memory also reflected both American and French domestic politics. Memories of military remains became safe ground for Americans and French to engage with each other in times of peace and conflict. Thus, analysis of the evolving memory assigned to American military bodies abroad helps inform broader diplomatic strategies. In the absence of U.S. military abroad following WWI, the United States strategically chose locations to leave a military presence abroad through war remains. The bodies signified a commitment to Western Europe and the similar ideals of the American and French Revolutions. Following WWII, the memory of aspiring power was replaced by a memory of real power. Through the Cold War, the tone of America's war memories in France changed as French perceptions of U.S. power altered.
\end{abstract}


In memory of Allen Barb, Lisle Hulver, Donald Hulver, Robert Hulver, Carroll Himelright, and J.R. McInerney. Each of you provided support and inspiration for this project in your own way. You all are greatly missed. 


\section{ACKNOWLEDGEMENTS}

The many demands of a doctoral program often brought emotional lows, stress, and feelings of isolation. The positives far outweighed these negatives. This process brought many joys and helped me appreciate how fortunate I am to have the love and support of so many. Providing thanks to everyone who contributed to this long endeavor would be impossible. For anyone who may read this, please know that no favor, thought, or gesture went unnoticed.

As the topic of this dissertation suggests, I must first show my appreciation for the sacrifices of the past generations commemorated in ABMC sites abroad. Thank you to the ABMC for allowing me assist in your important commemorative projects for a few summers. Secretary Max Cleland is a terrific individual and an inspiration to those who pass through his life. I also thank my undergraduate advisor, Dr. Mark Snell, for introducing me to this topic and for years of high expectations, challenges, and friendship.

I offer the upmost thanks to my dissertation committee. My co-chairs, Dr. James Siekmeier and Dr. Joshua Arthurs mentored me through my entire graduate program providing their expertise on U.S. diplomacy and collective memory. I thank you both for allowing me to think outside of the box in seminar papers, for reading all of my chapter drafts, and giving me vital suggestions. To Dr. Melissa Bingmann and Dr. Jason Phillips, thanks for consistently challenging me to view my topic from different perspectives. Dr. Kurt Piehler, although we did not work together within the same program, you have been central to this project. Your scholarship inspired me to research the American memory of wars and your support of my work gave me faith in my own ideas. I also want to give special thanks to my M.A. advisor, Dr. Peter Carmichael. Your graduate seminars and historical methodology caused me to mature intellectually and completely changed my perspective on how history is written. Dr. Bradley Coleman, you have shown me the work ethic that a good historian must have. I thank you for the opportunity you gave me with USSOUTHCOM and for turning me into a skilled archival researcher.

I thank my parents, Terry and Brenda Hulver, for always being examples of the type of person I want to be. I could have never completed this degree without your unwavering love and support. You never questioned my decision to pursue an advanced degree in history and showed nothing but optimism even during my lows. I cherish the warm home you have created for our family. To my brother, Matt, thanks for always being a friend and for our many fireside conversations. I consider myself lucky to have gained wonderful in-laws, Craig and Carolyn Spurlock. You have both shown me nothing but love and instantly made me feel like a valuable addition to your family.

West Virginia University will always hold a special place in my heart. The history department continually showed me support through teaching opportunities, scholarships, and research funding. I am particularly thankful for continuous support from my department chair, Dr. Elizabeth Fones-Wolf. Several individuals in WVU's history department deserve a special thanks. I can never thank Joel Christenson enough for all of the advice he has given me. I am glad that you ended up as my partner on the 
Manifest Destiny discussion in my first graduate class, Joel. You have been someone that I have looked up to ever since. Karina Faria Garcia Esposito and Joe Rizzo, it was a pleasure learning to teach with you. Josh Esposito, Jake Ivey, and Joe Snyder thanks for the office talk and for sharing teaching resources. Josh Howard, I will never forget our fun times in the 304 and on the town in Morgantown. Joe Phillips, Jamie Blake, and Beth McMullen-our late-night exploration of the Rail Trail will always stand out as one of my fondest Morgantown memories. Thanks to Graham Godwin for always offering a fresh perspective on anything and everything-there are too many good memories of our year at Beechurst to comment on here. Allison Finkelstein, I enjoyed working with you at the ABMC and consider you a great friend and scholar. Justin Arner, Curtis \& Marcy Dean, and Brett Zirkle-you are a special, and irreplaceable, group of friends.

To my beautiful and talented wife, Caitlin Spurlock Hulver, I thank you the most. Meeting you at the Blue Lot of a WVU football game and earning your love was by far my greatest accomplishment in Morgantown. I am more proud of your achievements than any of my own. I only hope that the support I gave you through dental school measured up to the support you gave me through my program. Freeing time to spend evenings with you made my comps studying more efficient and my dissertation writing more productive. We work in very different fields, but you edit, research, and challenge me to clarify my ideas like a historian. I value you more than words can express. 


\section{TABLE OF CONTENTS}

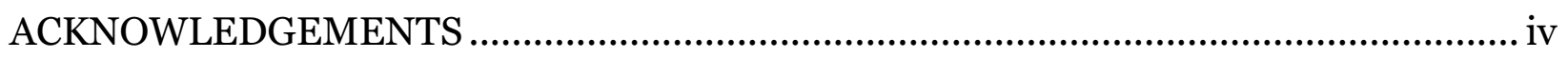

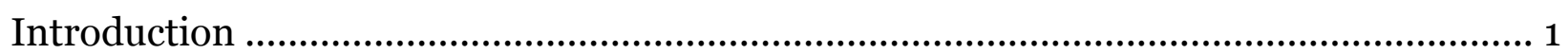

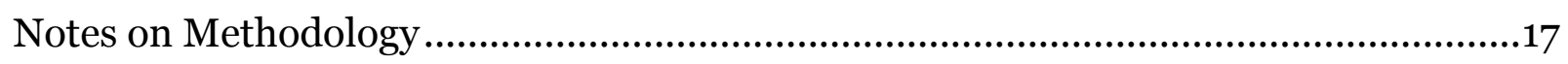

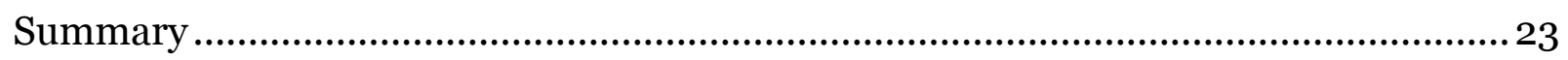

I. Becoming Instruments of Foreign Policy: Utility of American WWI Remains in

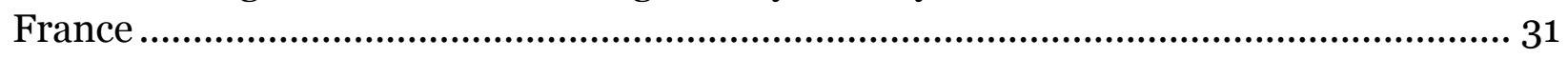

Origins of Memory as a Diplomatic Tool ………....................................................... 39

American Bodies in French Soil?................................................................................

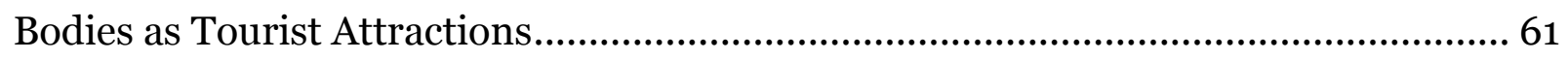

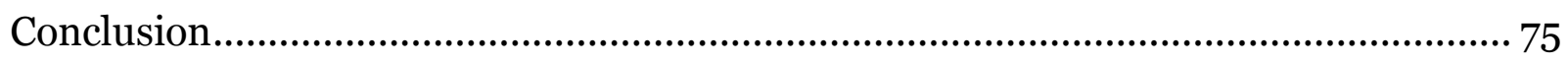

II. Politicizing God's Acres in 1920s France ……....................................................... 79

Rising Tensions: War Debt and American Enslavers .................................................... 87

Using Memory to Address the Red Menace ……………..............................................99

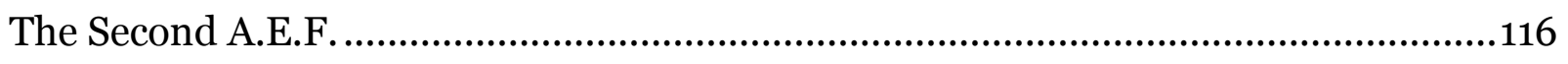

Conclusion.................................................................................................................... 125

III. Remains of Peace: U.S. Remains and the Coming of World War II .....................127

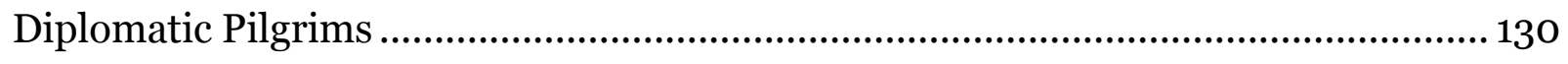

The Discourse of Peace ………………………..................................................... 149

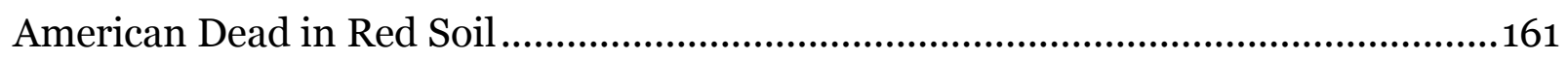

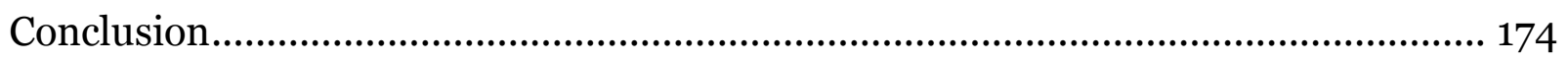

IV. Memory Diplomacy and the Second World War.................................................. 176

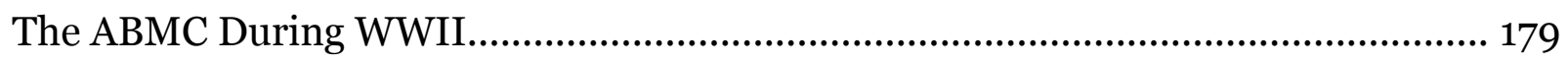

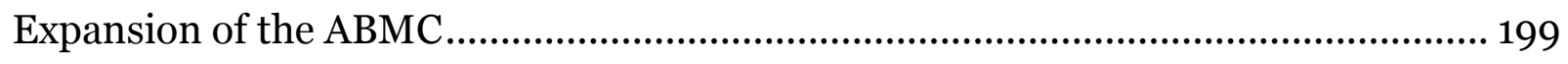

The Dishonorable Dead of Plot E ........................................................................... 210

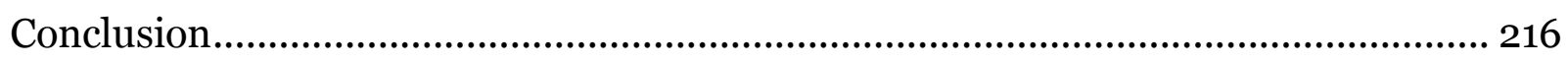

V. Guardians of Friendship: American Military Remains in Early Cold War France 218 Militant Undertones in God's Acres .....................................................................222

Will the French Fight? French Participation in American WWII Memory ................229

Yankee Go Home!: Memory as a Cold War Weapon...................................................248

Conclusion........................................................................................................... 274 
VI. Emissaries of Goodwill: Memory Diplomacy in the Post War Era ...................... 276

New Relations with the Fifth Republic...................................................................... 280

France Leaves NATO ..........................................................................................289

Thawing Tensions: A Return to Positive Memories ........................................................ 301

The ABMC on the Offensive ………………….................................................... 312

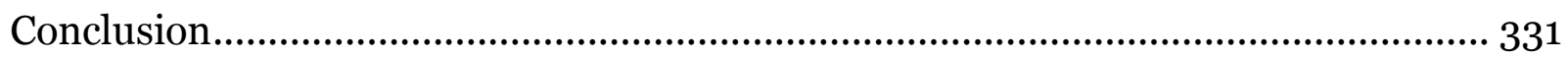

Conclusion: Contemporary Uses of U.S. Memory Abroad .............................................. 334

Dishonorable Barricades ........................................................................................ 347

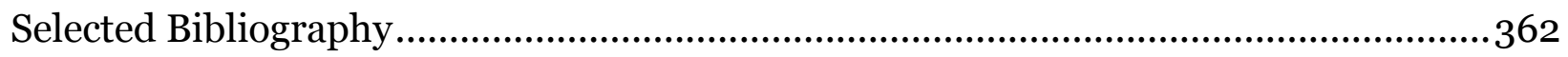

\section{List of Photographs}

Intro.1: Meuse-Argonne American Cemetery ...................................................... 4

1.1: Memorial Day at Suresnes American Cemetery, 5/30/19........................... 31

1.2: Wilson delivers Suresnes Speech, 5/30/19 .............................................. 34

1.3: French children wave U.S. Flags, Suresnes 1921 ........................................ 53

1.4: French soldier inscribing French headstone, 1915 ..................................... 56

1.5: Pershing leading ABMC battlefield tour, 1920s ............................................ 69

1.6: Pershing on Montfaucon, 1920s................................................................ 75

2.1: Ambassador Hugh Wallace at Trench of Bayonets, 1920 ........................... 87

2.2: Ambassador Myron Herrick at Suresnes, 5/1928 ....................................... 109

2.3: Pershing, Savage, Foch at Suresnes, 9/1927............................................ 119

2.4: West Virginia Legionnaires in Paris Parade, 9/1927.................................. 125

3.1: French laborers at Meuse-Argonne American Cemetery, 1928................... 130

3.2: Gold Star Mother passport photograph ...................................................... 134

3.3: Officer briefing Gold Star Mothers ............................................................. 147

3.4: Gold Star Mother at Arc de Triomphe ......................................................... 148

3.5: Speakers' podium at Montfaucon dedication, 8/1/37 …….......................... 160

3.6: Aerial view of Montfaucon dedication, 8/1/37 …....................................... 160

3.7: U.S. graves in Northern Russia, 1918 ……................................................ 167

4.1: U.S. soldiers before burial in France, 1944 …............................................ 195

4.2: Proposed U.S. memorial at Okinawa ........................................................ 210

5.1: French worker cleaning headstones at Suresnes, 1952 ............................. 218

5.2: U.S. Honor Guard at Suresnes dedication, 9/14/52 ................................... 227

5.3: Allied Parade through Paris, 8/25/44 ………........................................... 232

5.4: Marshall and Ridgway at Suresnes dedication, 9/14/52 ............................ 262

5.5: Marshall's Suresnes speech, 9/14/52 ..................................................... 266

6.1: Ambassador Shriver at Normandy, 6/6/69 ……….................................... 310

6.2: ABMC Secretary Cleland at Honolulu Memorial, 11/11/12 ........................ 331

Conclusion.1: Suresnes gates closed, 10/10/13 …............................................. 352 


\section{Introduction}

I first arrived at the Meuse-Argonne American World War I Cemetery in Romange-sous-Montfaucon, France in the pre-dusk hours of an unseasonably cool August day. A summer internship with the American Battle Monuments Commission (ABMC) brought me to this remote village in eastern France where U.S. soldiers fought in the Great War's final offensive. As part of a research team, my task was bringing to life the battlefield experiences of American soldiers buried within this cemetery for the ABMC's Great War Centennial projects. Tired from travel, I caught only a passing view of the white marble headstones before turning onto the access road to the superintendents' houses. These bungalow-style living quarters and the visitor center of the cemetery would be home for the next ten days. Hopes of walking the expansive memorial grounds that first evening diminished as daylight faded while unpacking and adjusting to new surroundings. Following a late dinner, I returned to quarters well after midnight to rest for the busy week ahead. A look out the window after darkening the room revealed that my introduction to the cemetery grounds could not wait until sunrise.

The Meuse-Argonne cemetery grounds create a sort of valley. A large memorial highway runs through its central low point. Fourteen thousand graves span the hill to the side of the road leading up to the memorial and chapel at its crest. To the other side of the road, is a large green field with a visitor's center and houses for the two American superintendents at its peak. My room was above the visitor's center, which directly aligned with the chapel on the distant opposing hill. Looking out into the darkness my 
first night in the cemetery it appeared that the memorial chapel was ablaze. In each loggia, and before the chapel doors, large flames shot into the night sky and faint shadows moved before them. Having heard nothing in orientation that might explain this occurrence, my colleagues and I hurriedly walked to the house of the superintendent. "I thought that might get your attention," was the greeting he offered waiting for us on his porch. He then explained that a French military regiment from nearby Verdun had asked to use the American cemetery as the site to initiate its newest members. It had slipped his mind that the initiation was that night. Not aware that the ceremony involved flames, he invited us to accompany him to the chapel for assessment of the situation. Together, we all walked in the darkness toward the distant fire. When we reached the asphalt road between the slopes, the sound of approaching boot steps caused us to pause. Through the darkness emerged a unit of camouflaged French soldiers leading a smaller group of men bound together with a large rope and sacks over their heads. Not seeing us, the soldiers turned and marched up the hill through the center of the burial grounds towards the flames. We silently followed, now more intrigued by what was taking place than the fires. The reflective glow of the moon off the field of white marble tombstones helped us see the way. The armed French soldiers became aware of our presence as we neared the chapel and their commander rapidly approached. After a short discussion, we learned that the flames were safely contained and that the hooded soldiers were the ones to be initiated. They had just completed their final twenty-five mile forced march, had been blindfolded, and unknowingly led into the cemetery. In thanks of allowing them to use this sacred American site, the French commander afforded us the rare opportunity to watch this initiation ceremony. 
The new soldiers were marched onto the chapel steps with their heads still covered and positioned to face the American graves. Once all were in place, the hoods were dramatically removed from the soldiers' heads. Shock of being in a large cemetery was evident on several faces. The commander let the moment sink in for a few heavy seconds. He then told the soldiers that they owed their freedom to American and French soldiers who sacrificed their lives in the Great War. His cadenced words echoed through the cemetery. He explained to them that they must be thankful for the sacrifice of American soldiers. This large American cemetery was chosen because it represented the inherent risk of their chosen profession. Each of the initiated was urged to understand the necessary willingness to make the same sacrifice for France as Americans did nearly a century ago. Following the speech, the soldiers received pins then sang their regimental song and the French national anthem. It was in this surreal moment of standing in a massive American World War I cemetery at 1:30 am, watching a secret military ritual, and listening to French soldiers sing La Marseillaise in torchlight that the idea for this dissertation took root. Although this site was the final resting place for American soldiers, it was far more than a cemetery. It was a sacred site that protected an American memory, but also elevated that memory into the realm of diplomacy. The presence of American military bodies, and their commemorative shrine, 
offered a gateway for French and Americans to articulate cultural ties.

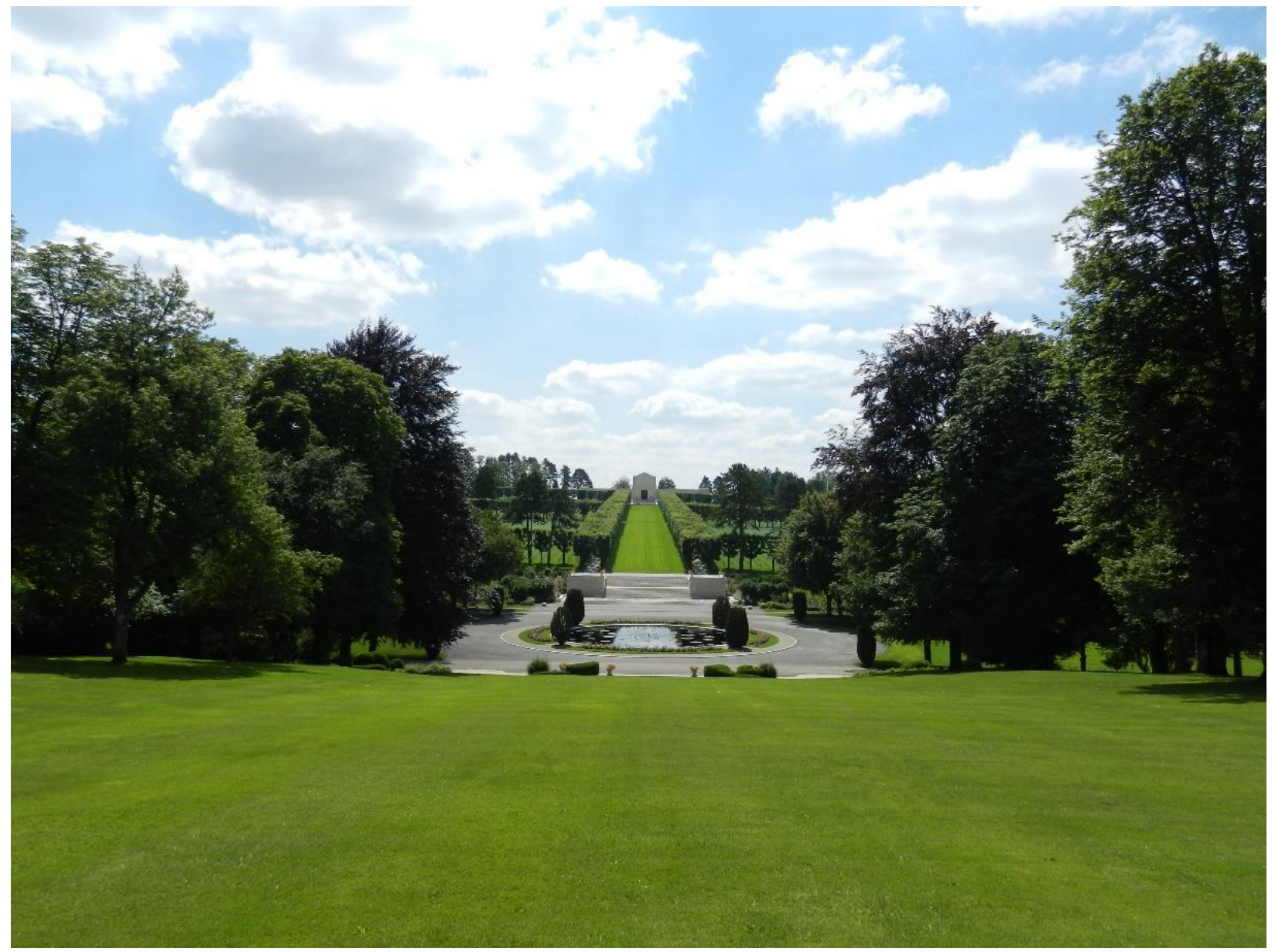

Intro.1: View from author's living quarters at Meuse Argonne American Cemetery with memorial chapel in far distance. Source: Taken by author August 2012.

Spread across six Western European countries, in 1,098 acres, are the remains of 104,113 American military personnel from World War I and World War II. ${ }^{1}$ Of this total, 60,510 American remains occupy 647 acres of French soil-28,544 in five World War I cemeteries, 30,401 in five World War II cemeteries, and 1,565 in the dual-war Suresnes

\footnotetext{
${ }^{1}$ Figures calculated from numbers maintained by the American Battle Monument Commission at http://www.abmc.gov/cemeteries/cemeteries.php, accessed April 15, 2014. The countries are: France, Belgium, England, Italy, Luxembourg, and Netherlands.
} 
American Cemetery outside of Paris. ${ }^{2}$ This study focuses on the American military remains in France and seeks to explain why those American bodies are there, and the utilitarian uses of their resting places. Remains cannot move themselves. So, why were so many American military dead left in France following World War I and II? Why, since 1918, has the U.S. government annually spent considerable sums of money to maintain those graves? How does the American government decide in what soil American military remains should rest, and in what soil they should not? Are the resting places of American dead present in France only to commemorate America's role in both world wars, or do they serve other purposes? How do Americans and French, at all levels of society, interact with these American resting places? Do memories of American military dead in France remain static, or evolve with time? These are the central questions that this work answers.

Although often not viewed as such, a nation's collective memory has use in international relations. The United States left some one-hundred thousand military remains interred in European soil following World War I and World War II, the majority of these in France. Congressional legislation created the American Battle Monuments Commission in 1923 to perpetually care for those remains and articulate their memory to the public. Even before this agency came into being, American and French leaders saw the important diplomatic uses that American remains possessed. Instead of resting in a symbolic void, the memory of American military dead abroad became a means for the living to express contemporary foreign policy goals. Elements of the American war memory abroad remained consistent through the twentieth

${ }^{2}$ Figures calculated from numbers maintained by the American Battle Monument Commission at http://www.abmc.gov/cemeteries/cemeteries.php, accessed April 15, 2014. 
century: sacrifice for a free Europe, fear of radical political revolution, and FrancoAmerican friendship. Yet, beneath the formulaic memory lingered evolving motives and commemorative assertiveness. Memories changed with international situations, as did the aggressiveness of the memory to address them. The memory also reflected both American and French domestic politics. Memories of military remains became safe ground for Americans and French to engage with each other in times of peace and conflict. Thus, analysis of the evolving memory assigned to American military bodies abroad helps inform broader diplomatic strategies. The shared collective memory of American war dead facilitated France and the United States in working together to eliminate or contain mutual threats and also allowed the United States a means to project power in Europe. These two outcomes did not always function cooperatively.

Historians have looked at the architectural rhetoric of American military cemeteries abroad, but generally, analysis halts here. ${ }^{3}$ American military dead are largely an untouchable piece of American culture. Questioning the uses, or motives, of leaving military remains abroad is not well received by the American public. Posts on the ABMC's Facebook page following the 2013 shutdown of the Federal Government, and temporary closure of cemeteries in France, impart the veneration that segments of the public still hold for remains killed long ago. One poster commented that "even the dead are disrespected by our politicians, outrageous." Another responded to a family that was turned away from visiting an uncle's grave that "If I was there, I would demolish the gate for you so you can visit your relative's grave, and then leave a blank

\footnotetext{
3 Ron Robin, Enclaves of America: The Rhetoric of American Political Architecture Abroad, 190o-1965
} (Princeton University Press, 1992). 
check in their office drop box to provide the money for damages caused." 4 The emotional nature of these posts reveal why some hesitation might exist among scholars to critically analyze non-commemorative uses of American military remains.

Historian Kurt Piehler offered the suggestion in his 1995 work Remembering War the American Way, that "overseas cemeteries served to symbolize U.S. global military commitments undertaken after 1945." 5 This implies an understanding that the location of American military cemeteries coincides with military alliances. More recently, Dutch historian Peter Schjrivers showed in The Margraten Boys how the Dutch people embraced the American WWII military cemetery at Margraten by adopting graves, and frequently using the cemetery to articulate their relationship with the United States. Schrijvers sees much more than military commitments in the locations of the American military cemeteries. He views them more as sites of "memory diplomacy.”6 Schrijvers never completely defines his conception of memory diplomacy, yet his work shows how the presence of American military remains in the Netherlands provides the Dutch a location to demonstrate commitment or displeasure with U.S. foreign policy by engaging with the memory of American dead. Memory diplomacy is a useful way to approach the topic of American military cemeteries. The current work weds Piehler's idea of military memory with Schrijvers' nascent conception of memory

\footnotetext{
4 Shelly Neidich, Facebook, last modified September 30 at 6:07pm, accessed October 1, 2013, https://www.facebook.com/abmcpage and Robery Rumsby, Facebook, last modified September 30 at 4:44pm, accessed October 1, 2013, https://www.facebook.com/abmcpage. Responses were from the ABMC's September 30, 2013 post: "In the event of a U.S. government shutdown beginning tomorrow, October 1, 2013, ABMC cemeteries and memorials will be closed to the public for the duration of the shutdown, and the ABMC Facebook page will not be available. We regret and inconvenience these temporary actions may cause. ABMC will resume normal operations when a new funding measure is passed by the U.S. Congress and signed by the President of the United States."

5 Kurt Piehler, Remembering War the American Way (Washington, DC: Smithsonian Press, 1995), 132.

${ }^{6}$ Peter Schjrivers, The Margraten Boys: How a European Village Kept America's Liberators Alive (New York: Palgrave MacMillian, 2012), 61.
} 
diplomacy. It argues that the memory of American military sacrifice embodied in ABMC cemeteries in Europe reflect aspects of American culture capable of transfer to a foreign audience for diplomatic purposes.

What is termed memory diplomacy in this work is not the first priority of leaders. No ambassador holds the title of "memory diplomat." Nor, is memory diplomacy a term defined by leaders and actively carried out, instead it tends to happen organically. Memory diplomacy is best viewed as one step toward achieving a desired political goal. Close attention to the rhetoric of memory and its usages indicates the trajectory of foreign policy aspirations. If one studies foreign policy goals and then analyzes the many steps taken by leaders to achieve those goals, the methods will reveal themselves in a variety of ways. Throughout the twentieth century, engaging with the memory of military dead consistently showed itself to be an avenue to champion foreign policy objectives. American cemeteries are as much sites of memory diplomacy as military relics. The living make annual pilgrimages to these sites and use the memory of American military dead to provide meaning to present international situations and see evidence of an amicable relationship. It is understood that American foreign leaders do not immediately turn to military cemeteries to influence foreign policy in the direst of situations. Yet, the rhetoric of leaders on special occasions in military cemeteries and in the midst of developing international situations effectively reveals a snapshot of a broader foreign policy goals. In other words, American military cemeteries are not the ends to achieving a policy goal, but a means to articulate bigger goals and comment on contemporary inter-state relations.

The American soldiers buried at Meuse-Argonne died nearly a century ago, yet their bodies remained on French soil in a space designated as sacred by the American 
government. This space was not merely to commemorate American sacrifice, but had utilitarian value. It is a site that shows American bonds with its host country. Similarly, it allows the living from all nationalities to gather and provide a voice for those long gone. American military bodies permit sites like this to have meaning. Without the feeling of humanness, vocalizing a memory becomes difficult. The remains of these soldiers continue to serve their country. They tell visitors of key elements in American culture: military sacrifice, commitment to a Franco-American partnership, JudeoChristianity, social equality, democracy, and capitalism-all things the remains supposedly died for. The human sacrifice represented by the graves give validation to the messages imbedded in the chapels, memorials, landscaping, and commemorative speeches. Without remains, the meanings of the sites would be greatly diminished.

This work seeks to bridge multiple historiographic gaps. It will tie together the American and French memories of both world wars using the resting places of American military remains as a meeting place of Franco-American culture. It will look at the way citizens of France and the United States view themselves, and one another, through the memory of American military remains. Diplomatic history is the primary lens through which these American military cemeteries are analyzed. Historian Ron Robin effectively showed that ABMC sites serve U.S. public diplomatic needs. A nation's public diplomacy is a form of "soft power," a method of projecting power abroad through more peaceful cultural channels as opposed to the blunt physical force of military intervention. ${ }^{7}$ Although military cemeteries certainly present a memory of violent international periods, they predominately transfer more peaceful cultural messages

\footnotetext{
7 Joseph Nye, Soft Power: The Means to Success in World Politics (New York: Public Affairs, 2004).
} 
between nations. Public diplomatic sites are easily accessible to the general public and intended to be present in everyday life. These locations convey well thought out messages intended to "impress, but not annoy" foreign audiences, showing them what makes American culture appealing. The most successful public diplomatic sites should tactfully draw on the heartstrings of foreign audiences to create mental ties between nations. ${ }^{8}$

The spread of military memory through remains primarily falls under the broad umbrella of cultural diplomacy. A nation's collective memory is a cultural product just as capable of transfer to bolster international relations as more studied cultural exchanges like consumerism: Levis, Coca-Cola, Wrigley gum, and Hollywood films. ${ }^{9}$ Because the collective memory transferred for a diplomatic purposes is one of military sacrifice, this work also incorporates military history into the analysis of the diplomatic uses of memory as well.

The centennial of the Great War's beginning and the seventieth anniversary of the Second World War's end are approaching as this study is written. Scholars have exhaustively covered these conflicts from almost every angle-motives for fighting, military strategies, biographies, and studies of both wars' legacy. Studying the collective memory of the conflicts proves a worthy analytical approach as well. These memory

\footnotetext{
${ }^{8}$ Ron Robin, Enclaves of America, 52 and Schrijvers, Margraten Boys, 61.

9 For similar studies of anti-Americanism and cultural transfers between Europe and the United States see For examples of cultural transfer studies see works like Peter Schrijvers, The Crash of Ruin: American Combat Soldiers in Europe During World War II (New York: New York University Press, 1998), Reinhold Wagnleitner, Coca-colonization and the Cold War the Cultural Mission of the United States in Austria After the Second World War (Chapel Hill: University of North Carolina Press, 1994), Richard H Pells, Not like Us : How Europeans Have Loved, Hated, and Transformed American Culture Since World War II (New York, NY: Basic Books, 1997), Victoria De Grazia, Irresistible Empire : America's Advance Through Twentieth-century Europe (Cambridge, Mass.; London: Belknap Press of Harvard Univ. Press, 2006), Richard Kuisel, Seducing the French: The Dilemma of Americanization (Berkeley: University of California Press, 1993).
} 
studies not only teach us about the past, but also reveal trends in contemporary cultures. For scholars looking at American memory of both wars, the central questions seem to center on the public amnesia of the Great War and the demystification of the Second World War's 'greatest generation.' European scholars, on the other hand recognize that the Great War is very much alive in their collective remembrance and in many ways outshines their WWII memory. European scholars of the Second World War using memory as their analytical approach tend to focus on the search to find a usable memory among landscapes of atrocity and guilt. Much of this focuses on the dichotomy of victims and perpetrators, in hopes of healing wounds and moving forward.10

Almost always, memory is associated with the past, or manipulation of the past to affect the present. Diplomacy, on the other hand, seldom triggers connection with the past. Diplomacy takes place in the present. It deals with the current relations between nations and offers solutions for the future. The past certainly is not totally absent in diplomacy, however. Good diplomatic relations heed history. ${ }^{11}$ Still, memory and

\footnotetext{
${ }^{10}$ Stephen Trout, On the Battlefield of Memory: The First World War and American Remembrance, 1919-1941 (Tuscaloosa: University of Alabama Press, 2010), Lisa Budreau, Bodies of War: World War I and the Politics of Commemoration in America, 1919-1933 (New York: New York University Press, 2010), Mark Snell ed., Unknown Soldiers: The American Expeditionary Forces in Memory and Remembrance (Kent, Ohio: Kent State University Press, 2008), Kurt Piehler, Remembering War the American Way (Washington, DC: Smithsonian Press, 1995), Michael Adams, The Best War Ever: American and World War II (Baltimore: The Johns Hopkins University Press, 1994), Kenneth Rose, Myth and the Greatest Generation: A Social History of Americans in World War II (New York: Routledge Press, 2008), Timothy Snyder, Bloodlands: Europe Between Hitler and Stalin (New York: Basic Books, 2010), Tony Judt, Postwar: A History of Europe since 1945 (New York: Penguin Press, 2005), Lothar Kettenacker and Torsten Riotte, The Legacies of Two World Wars: European Societies in the Twentieth Century (New York: Berghahn Books, 2011), Robert Moeller, War Stories: The Search for a Usable Past in the Federal Republic of Germany (Berkeley: University of California Press, 2001), Luisa Passerini, Fascism in Popular Memory: The Cultural Experience of the Turin Working Class (Cambridge: Cambridge University Press, 1987), Henry Rousso, The Vichy Syndrome: History and Memory in France sine 1944(Cambridge, Massachusetts: Harvard University Press, 1991), J.M. Winter, Sites of Memory, Sites of Mourning: The Great War in European Cultural History (Cambridge: Cambridge University Press, 1995).

${ }^{11}$ Richard Neustadt and Ernest May, Thinking in Time: The Uses of History for Decision Makers (New York: The Free Press, 1986).
} 
diplomacy are on different planes. The history of the future offers a remedy for this disjuncture. Roxanne Panchasi's study of interwar France shows how societies temper their memories of the past according to their anticipation of the future. Panchasi suggests that because individuals have little control over how their future unfolds, they create a nostalgic past as a proactive measure to make the uncertainty of what might come more bearable. ${ }^{12}$ The public memory of the past that is visible effectively reveals what a society hopes for in the future. This idea explains how memory diplomacy functions in American military cemeteries. The memory of the World Wars represented in American military cemeteries reflects American desires for a future of diplomatic power and dominance in the Old World. The American memory of both World War I and World War II reflected this anticipation of the future. Following World War I, the United States failed to fully commit itself to European politics. Yet, the memory of its remains in Europe reflected an aspiration of a strong American presence abroad. Following WWII, this aspiring American memory was replaced with a more aggressive memory reflective of real international power.

War remains, their symbolic importance, and the livings' interaction with them are the core of this study. Scholarly attention to the significance of remains in forging a collective memory and national identity is currently popular in memory studies and public history. ${ }^{13}$ Memory is such an important mode of analysis because contemporary society still struggles to remember a version of the World War era that is politically

\footnotetext{
12 Roxanne Panchasi, Future Tense: The Culture of Anticipation in France Between the Wars (Ithaca: Cornell University Press, 2009), 6, 161.

13Michael Sledge, Soldier Dead: How We Recover, Identify, Bury, and Honor our Military Fallen (New York: Columbia University Press, 2004); Katherine Verdery, The Political Lives of Dead Bodies: Reburial and Postsocialist Change (New York: Columbia University Press, 1999); Wright, "Where are the Bodies? In the Ground," Public Historian, No. 1, Vol. 32, (2010), 96-107.
} 
usable. Additionally, the rapid disappearance of historical actors from this era has caused an anxiety to record their memories while possible. In a recent past rife with victims and perpetrators, it is necessary to heal wounds, seek forgiveness, and move in a forward direction. Accomplishing this generally requires efforts from the state to manipulate narratives, focusing on the good and pushing aside the bad. Successful manipulation of memory requires tools, and ways to package memory for the public. Bodies of historical actors killed during specific periods serve as some of the most usable instruments of memory transfer. Instead of focusing on the obvious logistical questions regarding war remains: recovery, identity, ownership, and repatriation, more focus on the political and cultural uses that governments find in war remains is needed. The messages that the living assign to remains are not as static as the decomposing matter they are. Anthropologist Katherine Verdery's analysis of the politics of human remains in post-Soviet Eastern Europe has informed this project greatly. She posits that because bodies reflect an image of complex lived life, humans assign more symbolic meaning to them than other lifeless relics such as brick, mortar, or art. The complexity of remains makes them artifacts that are both "concrete and protean."14 Leaders are able to capitalize on the powerful connotations that the living attach to them, and put words into mouths of the deceased. These words create a message that fulfills a societal need of the living. In short, it is easier for governments to "rewrite history with dead people than with symbols that never spoke."15 American scholar Michael Sledge made similar observations about political uses of American military dead in his 2005 work, Soldier Dead. Sledge contended in his work that "a soldier's body is the physical representative,

14 Verdery, Political Lives, 28.

15 Ibid., 29. 
or envoy, of his nation and, as such, embodies its ideology, political beliefs, and culture."16 For the American government to retain legitimacy and support of the American people, it needs to care for those that serve it in life and death. Sledge argued that the government's ability to care for the corpses of its soldiers became indicative in the public mind of the government's ability to care for the living. ${ }^{17}$ Sledge failed to grasp the larger implications of leaving American remains overseas. In his view, the ABMC caretaking is reflective more of an inconvenient burden that Washington had to undertake when hundreds of thousands of American soldiers died abroad because to not do so would have caused public mutiny. ${ }^{18}$ He does not acknowledge the presence of other government motives in the decision.

A nation's capacity and aspiration to care for its war dead reveals much about its cultural and political priorities. The fact that the United States Congress appropriated over fifty-seven million dollars to the ABMC in 2013 to care of American soldiers' graves killed abroad in the era of World Wars shows that Americans place both emotional and monetary value on their war dead. ${ }^{19}$ This sum has remained relatively unchanged for the past several years despite a faltering economy and multiple wars in the Middle East. If the billion dollar marker has not been reached in caring for these dead since 1923, it soon will. Although U.S. policy since the Korean War has been to repatriate all American service members killed, and recovered, this was not so for the World Wars. Next-of-kin received a choice from the federal government to decide the final resting place of their soldier dead in these conflicts. A little fewer than half of the families of

\footnotetext{
${ }^{16}$ Michael Sledge, Soldier Dead, 26.

17 Ibid.

18 Ibid.

19 This figure came from the ABMC's "Fiscal Year 2013 Annual Report,"

http://abmc.gov/commission/ABMC 2013 Annual Report.pdf, accessed January 23, 2014.
} 
deceased Americans in each World War, respectively, opted to leave the dead where they fell. These families did so with the promise of their government that "time will not dim the glory of their deeds.” ${ }^{20}$ Ensuring the perpetuity of this promise requires a steep price tag. Still, this bill is one that a majority of American deem worthy of paying. The service provided not only commemorates the dead, but also ensures that the cemeteries and monuments displaying American culture remain immaculate and open for public diplomacy on all days except federal holidays. Americans seldom ask what other value these cemeteries possess. Are they purely the self-evident sites of commemoration that they appear as? Or, does the American government spend so much money on these sites to fulfill more practical needs of statecraft?

Death is a universal human experience. Civil War historian Drew Faust argues that even when dying, humans are active, not passive participants. They spent a lifetime preparing for their final moment, "imagining it, risking it, enduring it, and seeking to understand it." ${ }^{21}$ The living must find their identity and alter their lives according to the persistent "annihilation" of their fellow man. ${ }^{22}$ Human remains universally connote deep meanings with the living. This is evident in a variety of ways. They elicit thoughts of mortality and a spiritual afterlife in many religions and cultures. ${ }^{23}$ Indigenous groups and politically weak nations use their dead as one of the few available political weapons. They actively seek to repatriate their remains that powerful enemies took for trophies or scientific experimentation. They consequently want the remains of enemies

\footnotetext{
${ }^{20}$ This is a quote from General John J. Pershing following WWI, and serves as the official motto of the American Battle Monuments Commission of which Pershing was its first chairman.

${ }^{21}$ Drew Faust, This Republic of Suffering, Death and the American Civil War (New York: Knopf, 2008), $\mathrm{XV}$

22 Ibid.

23 Gary Laderman, The Sacred Remains: American Attitudes Toward Death, 1799-1883 (New Haven: Yale University, Press, 1996), 5 .
} 
removed from their own land, along with the victorious memories assigned to them. Sometimes they use the presence of their remains in soil to legitimize claims of land ownership. In all of these cases, control of your own dead represents ownership of your past, and a balance of power. ${ }^{24}$ Groups who lack political power are not the only ones who leverage their dead. Powerful national governments, like the United States, "glorify the remains of figures who significantly reflect the principles and mission of the nation," they "confer immortality on particular national heroes" to consecrate sacred spaces. 25 The ability to care for its own dead and be accountable for the wrongful death of others also rectifies a nation's power. ${ }^{26}$ When a collective group of remains possess substantial cultural meanings to a people, they become even more powerful. In the United States, military sacrifice represents one of the most sacred cultural traits. ${ }^{27}$ Thus, writing about American military remains is a difficult subject. Hyper-patriotism throughout the United States makes questioning the use of military remains somewhat controversial. This is particularly true when dealing with any engagement of the dominant narrative of the American military's noble sacrifices in the World Wars. ${ }^{28}$

The twenty-four ABMC sites abroad are capable of assigning different meanings to each individual. Some might see the thousands upon thousands of headstones as a message of peace where others see a message of American military might. This varied message comes from American leaders themselves. Throughout the twentieth century,

\footnotetext{
24 For this type of argument see Andrew Gulliford, "Bones of Contention: The Repatriation of Native American Human Remains," The Public Historian, Vol. 18, No. 4, (Fall 1996), 119-143 and Vedery, The Political Lives of Dead Bodies.

${ }_{25}$ Laderman, The Sacred Remains, 6.

${ }^{26}$ The Public Historian: Where are the Bodies? A Transnational Examination of State Violence and its Consequences, Vol. 32, No. 1 (February 2010).

${ }_{27}$ Faust, This Republic of Suffering.

28 The politicization of the WWII monument on the National Mall in DC during the late 2013 government shutdown provides contemporary evidence of this.
} 
and into the twenty-first, leaders gave multiple voices to the soldier dead. The only constant variable in these sites has been a discourse of American sacrifice for the broad ideals of democracy, liberty, and freedom.

\section{Notes on Methodology}

America's military cemeteries are divided by a distinct chronological barriereight are from the Great War and sixteen from World War II. While sharing many similarities, analysis of these sites of memory from different wars requires some separation. Similar difficulties arise due to geographic considerations. Although the vast majority of the cemeteries are in Western Europe (Manila, Carthage, Corozal, and Mexico City being the exceptions), it would be irresponsible to lump them all into an overbroad categorization of Western Europe.29 Each cemetery has a unique history determined by local factors. For instance, the feeling of the Suresnes American Cemetery on the outskirts of Paris is quite different than the much more isolated MeuseArgonne American cemetery in eastern France. Engagement of locals in the cemeteries also varies by location. Historian Peter Schrjivers shows a storied past of Dutch citizens reverently adopting American military graves in Holland. Grave adoption programs exist at other ABMC cemeteries, but none quite reach the scope or thoroughness of the Dutch example. $3^{30}$ Conversely, while it is not useful to broadly frame all cemeteries in a Western European mold, it is also not useful to view them as isolated locations with no connection to one another. America's military cemeteries are standardized

\footnotetext{
29 Corozal in Panama and the cemetery in Mexico City are markedly different than other ABMC sites. ${ }^{30}$ Peter Schrijvers, The Margraten Boys.
} 
representations of American sacrifice created by a federal commission as part of an overarching plan to assert an American presence in Europe. Essentially the only difference from cemetery to cemetery is size, memorial design, and the secondary language of text. All of the ABMC's WWI and WWII cemeteries were respectively built as the same house with different paint. Still, this does not mean that foreigners treat each cemetery the same way, or that the American government uses each site in a completely standardized fashion. It was impossible to know in the early 1920 s how a town where an ABMC cemetery was located might look in the distant future. For instance, at Meuse-Argonne American cemetery a grand highway connecting Romangesous-Montfaucon to neighboring towns was optimistically built through the American cemetery. The town never grew however, and the large highway remains bookended by small country roads.

An additional obstacle placed in front of scholars of this subject is the number, and quality, of sources available regarding each site. At its moment of conception, the ABMC was a historically minded commission dedicated to not only to building and maintaining cemeteries and monuments, but to writing accurate histories of the American Expeditionary Forces. Its founders rightly understood that good commemoration and history went hand-in-hand. The appointment of Major Xenophon H. Price as the commission's first administrative secretary attests to this. His capacity as chief mapmaker on Pershing's personal staff during the war made him the expert on American military positions in the Great War. ${ }^{31}$ Much of this historical mindedness

\footnotetext{
${ }^{31}$ Hearings Before the Committee on Foreign Affairs, House of Representatives, Sixty-Seventh Congress, Second and Third Sessions on H.R. 9634 and H.R. 10801 for The Creation of an American Battle Monuments Commission to Erect Suitable Memorials Commemorating the Services of the American Soldier in Europe, March 15-20, November 28, December 7-9, 1922 (Washington, D.C.: Government Printing Office, 1922), 49, 52.
} 
began leaving the ABMC once its cadre of WWI leadership faded away. At the conclusion of WWII, the greatly expanded military machine of the United States took over much of the historical part of the ABMC's mission. Where the ABMC created the official history of the A.E.F. following the Great War, the U.S. Army's historical section compiled the official WWII history. Thus, following World War II much of the ABMC's institutional commitment to produce historical products to accompany its commemoration began to diminish. The commission became an agency less concerned with telling a story, and more concerned with keeping the grass green and the headstones white. This system worked while the World Wars remained fresh in the American consciousness. As the WWII generation aged and began to die, this lived memory also dissipated. Americans no longer needed an ABMC that served as a mere caretaker of graves and memorials, but one capable of historical interpretation. Thankfully, more of a historical mind seems to be returning to the commission at the start of a new century.

This recent institutional return to history does not help historians writing the history of the ABMC, however. Records of the commission's early work are rather comprehensive at the National Archives, but as the twentieth century progressed, the quality of archival material devolved into little more than administrative minutiae. Historical records of individual ABMC sites vary with each location. Some of the WWI records stored within buildings on cemetery sites vanished during Nazi occupation of Europe, or during the transition of administration between the Graves Registration Service and the ABMC. ABMC sites in Europe also vary greatly by leadership. Many cemeteries are in remote locations and are cared for by an American superintendent who lives on site with their family. An administrator is always on duty to meet with 
guests and direct a staff of workers from the host-country. They often take residence at a specific cemetery for several years, and then move on to oversee another. With only moderate direction from ABMC headquarters in Washington or Paris, these administrators can set an agenda and use spare time depending on personal discretionso long as they fulfill the commission's mission. Some administrators are more historically minded than their counterparts and make an effort to chronicle the lives of remains buried within the walls they tend, record interactions with visitors, etc. As a result, some cemeteries have much more complete historical holdings than others depending on the caretaker. $3^{2}$

My goal with this work is to walk the analytical tightrope, trying to bring specificity while not losing focus on broader connections. In the following pages, much focus is given to the Suresnes American Cemetery and the Meuse-Argonne American Cemetery. These two cemeteries, one in France's main metropolis, and the other in its remote eastern frontier, are indicative of my focus on Franco-American relations through the twentieth century. France is the primary receptacle of American military dead from the World Wars, and one of America's closest allies throughout the past century. Aside from the historic democratic alliance borne from each nation's revolution, Franco-American relations are also historically strained. Twentieth-century Franco-American relations are best characterized by allegiances built out of necessity. Feelings of mistrust, misunderstanding, and animosity are the norm. I focus on Suresnes and Meuse-Argonne out of the need to limit my sample. Of the eleven American World War cemeteries in France, Suresnes deserves attention because it is the

$3^{2}$ These observations on the historical assets of the ABMC are made from exposure to ABMC archives as a graduate student and from two summers interning as a historian with the commission. 
only cemetery with burials from both World Wars, and because of its proximity to Paris. Meuse-Argonne is noteworthy because it is the largest American military cemetery in Europe and represents the main American sacrifice in the Great War. The two very different cemeteries allow for a strong conceptualization of American military cemeteries in France. Still, focus on these locations does not mean I am binding myself to one cemetery from eastern France and one from the west. Chronologically, I intend to show the continuity of change in ABMC sites from their inception into the present. While I would like my vision to be a perfect tapestry, it is not so. The narrative of American commemoration in Europe is riddled with holes that must be mended to see its entirety. Many of these gaps will be filled by relevant examples found in cases from other cemeteries. Put simply, this is not a case study of Suresnes or Meuse-Argonne, nor is it an attempt tell the story of every ABMC site in Europe. It is a study that understands its limits and creatively seeks to find answers. Time and place create many different stories, but a common thread runs through all. This thread shows that ABMC cemeteries are more than depositories for American military dead and isolated lighthouses spread throughout continental Europe. Instead, they are cultural representations of the United States strategically placed for political and diplomatic use. The dead within their walls do not always rest in peace, but are frequently summoned to aid the living.

As sites of public diplomacy, American military cemeteries have had mixed success depending on time and international situations. Immediately following World War I and World War II, American cemeteries had near-unanimous support from host nations. American remains represented liberation from period of oppression still in recent memory. Shifting international politics altered these positive images. During the 
interwar years, war debt policies and radicalized political movements on the left and right increased French animosity towards the United States. Following World War II, virulent anti-communism, control of nuclear weapons, and unpopular proxy wars eroded American popularity in Europe. American military cemeteries were not immune to the changing diplomatic situations. As sites strongly representative of American culture, cemeteries became possible targets for the French to protest against the perceived U.S. overtaking of the Old World. Both World War I and World War II are what some scholars consider two glimmering periods in a century of Franco-American relations mostly characterized by tension. French historian Philippe Roger notes that "brotherhood in the trenches was replaced by a new, uncomprehending transatlantic dialogue." 33 The period of misunderstanding began shortly after WWI and then again shortly after WWII. Members of the American armed services left in European soil during these times of uncomprehending were called upon to bring reason and understanding to current American intentions. Sometimes the voice of the dead alleviated misunderstandings between nations and strengthened bonds between nations - the eve of WWII stands as a great example of this. At other times, the voices failed to resonate with the host nation, and only served to reaffirm cultural differences.

The pages that follow will show both the fluidity and consistency in American political uses of military remains from the World Wars. This work largely flows chronologically to reveal to the evolution of the discourse of war dead. The discourse of the dead is not a one-sided American construction, but defined and redefined by Americans, the French, and other Europeans as international situations evolved over the

33 Philippe Roger, The American Enemy: The History of French-Anti-Americanism, trans. Sharon Bowman (Chicago: University of Chicago Press, 2002), 259. 
twentieth century. Research for this project draws primarily from State Department Records, U.S. Consular Post Records, U.S. Army Quartermaster Records, Records of the Joint Chiefs of Staff, American Battle Monuments Commission Records, and Commission of Fine Arts Records. The personal papers of ABMC staff and U.S. Ambassadors to France during specific time periods have also invaluably shown how American leaders used cemeteries to achieve diplomatic goals. Because this work is not concerned only with the decisions of top level officials, efforts have been made to uncover the voices of American and French tourists and visitors to U.S. cemeteries. Newspaper archives, letters in burial files, War Department surveys, and State Department correspondence have provided this personal perspective. Published memoirs of French and American tourists and diplomats have also contributed to this work.

$\underline{\text { Summary }}$

The American memory of its sacrifice abroad fluctuated between liberal and conservative world views through the twentieth century. Chapter I explains how President Woodrow Wilson first cast the memory of American WWI dead in France as a sacrifice for a liberal world dedicated to open borders, free trade, collective defense, and self-determination. This memory generated positive expectations among decimated European allies and debate within the United States. Wilson articulated his liberal view in a dedication speech given at Suresnes American Cemetery outside of Paris during Treaty of Versailles meetings. To him, doughboys died to pave the way for a League of 
Nations and its goal of collective security. American leaders and the public split on this memory and debated whether their bodies should stay in Europe as reminders of this sacrifice, or come home. Some thirty-thousand remains stayed abroad in European soil under the care of the new ABMC led by General of the Armies John Pershing. The commemorative system created by the ABMC abroad established strategic locations for American and French leaders to use American memories of the war as commentary on contemporary issues. During the interwar years, the American memory on French soil reflected U.S. diplomatic aspirations more so than real power.

A decade of conservative leadership revised U.S. memory abroad following Woodrow Wilson's presidency. The roaring twenties, popularly perceived as a time of growing U.S. prosperity and cultural relevance, also represented a period when U.S. policymakers rejected the tenets of the League of Nations. Distancing the United States from European political and military entanglements was a primary American foreign policy goal. The desire to stay out of European problems coincided with the growing influence of left-wing and right-wing political movements abroad. Communists offered Europeans an alternative to democratic capitalism and growing fascist movements vocalized disenchantment over war reparation policies. Chapter II shows that with no U.S. military presence in Europe, the memory of American remains became a viable platform for U.S. policymakers to respond to anti-American protest stemming from these groups. The optimistic memory that Wilson assigned to American dead evolved into a reactionary memory attacking political radicalism. Maintaining its traditional policy of freedom of action regarding political and diplomatic engagements, the United States faltered on fully committing to European problems. But, through its memory of doughboys in French soil, articulated a continued investment in the free world. The 
memory of American soldiers buried in France increasingly focused on positive similarities imbedded in the 'good' revolutions of France and the United States. There was no American military presence in Europe, but the memory crafted for American remains suggested that so long as European countries adhered to democraticcapitalism, American force might come to their aid in future conflict. Some of the most visible uses of U.S. memory working to improve Franco-American relations came in the wake of war debt manifestations and Sacco-Vanzetti protests in the streets of Paris.

Franklin Roosevelt assumed power at the height of the Great Depression and fascist leadership in Italy and Germany. Chapter III shows that through the 1930s, the memory of American military dead abroad harkened back to Wilson's peaceful designs instead of retroactively responding to social unrest. The message of peace associated with American memory abroad came from leaders in the United States and citizens travelling as pilgrims. The U.S. Congress funded pilgrimages for mothers and wives who lost loved ones in World War I to visit graves abroad. These women traveled as public diplomats through the 1930s. Grieving American women showed Europeans the continued U.S. investment in international stability. In the late 1930s, as fascist governments initiated aggressive foreign policy, the United States and France turned to memories of American remains to bring peace to the continent by containing nationalist aggression. A wave of official ABMC dedications in Europe in 1937 created a timely platform for U.S. and French leaders to espouse public messages of peace. In this period where U.S. memory abroad offered hope for peace in Western Europe, the United States also attempted to remove its dead from Soviet soil who died fighting Bolsheviks in the years after the Great War. This recovery mission came in the first year that the United States gave the Soviet Union diplomatic recognition. It attempted to not only 
recover American remains for grieving families, but also to erase a negative memory from Soviet soil.

Peaceful memories of American military remains in Europe failed, of course, to stop the European economic and diplomatic crisis of the 1930 from becoming a second world war. Yet, the diplomacy of collective memory surrounding remains continued to tie France and the United States together during the war and proved especially important in the post-war era. Chapter IV analyzes the expanding utility of American military memory during World War II. After France's capitulation to Nazi Germany, and prior to U.S. entry into the war, the French retained hope that the United States might come to their aid and showed continued commitment to America. One sign of this commitment was the French government's circumvention of the Vichy regime to maintain U.S. WWI graves. Once the United States entered into World War II, its war presence abroad entirely dwarfed the scope of its WWI contributions. Throughout the war, U.S. military leadership and leaders in the ABMC took measures to ensure that its new war memory abroad reflected the increased American sacrifice and commitment to a free world. Efforts were made to ensure that a majority, or all, new U.S. military dead might be left abroad. Not all dead remained abroad, but approximately 100,000 didmost in France. These dead entered into the same U.S. WWI commemorative system, but one on a much larger scale. The ABMC's commemorative boundaries following WWII encompassed the globe. This expanded sphere of memory overlapped with increased U.S. influence abroad in the new Cold War.

Through the first two decades of the Cold War, the United States increasingly used the memory of its military remains as a means to project U.S. power abroad and make Europeans view the U.S. in a favorable light. Positive memories of American 
sacrifice in the World Wars helped pave the way for America's twentieth century ascension, more so than other cultural influences that generated European scorn, like U.S. consumerism. The more assertive uses of memory as a diplomatic tool stemmed partially from the volatile ideological battle between the United States and the Soviet Union. It also came in response to growing anti-Americanism in France regarding growing U.S. dependency. Discontent manifested in France in the form of widespread communist protest of U.S. and French policies in Korea and Indochina. When communist protestors attacked NATO and other symbols of U.S. dominance in France, U.S. leaders and conservative French leaders turned to popular memories of U.S. soldier dead to ease tensions. Chapter V demonstrates how American dead in this early Cold War period became weapons and reminders to France of the significant sacrifices that the United States made for France in the recent past. French and American leaders conceptualized American dead from the World Wars as extensions of shared FrancoAmerican battles against communists in the Far East in the very early stages of the Cold War.

Chapter VI asserts that the aggressive uses of U.S. military memory through the 1950 s became more reserved during the liberal presidencies of JFK and LBJ. Throughout Kennedy's brief presidency, he and his diplomatic appointees focused less on using American remains in France as weapons. Instead, more emphasis went towards highlighting positive memories of the centuries old Franco-American partnership and the future. The sentimentality of U.S. memory did little to improve Franco-American governmental relations through the 1960s. Much of the barrier came from realist French President Charles de Gaulle's leadership of the Fifth Republic. General de Gaulle strove to reassert France as a major international power independent 
from the United States. The United States' withholding of nuclear technology from France, escalation in Vietnam, and insistence on France trusting NATO as its primary defense all increased French anti-Americanism. The low-point of twentieth century Franco-American relations came in 1966 when President de Gaulle withdrew France from NATO and demanded all U.S. military personnel leave French soil. This briefly turned U.S. remains back into diplomatic weapons and caused the U.S. Congress to consider removing all U.S. military bodies from France. By 1968, the American memory of its remains in France had moderated again because of international protest against the U.S. war in Vietnam. Washington ordered U.S. diplomats to avoid Vietnam references in public speeches and the U.S. military memory in Europe became a less militarized than ever before. The ambassadorship of Sargent Shriver epitomized the toned down rhetoric of American memory in this period. Decreased public attention to ABMC sites in the late 6os and Congressional debates to abolish the Commission also indicated the diminishing value Americans placed on military memory abroad.

In large part due to the mounting death toll in Vietnam, coupled with faltering support amongst the U.S. and European public, President Richard Nixon reinvigorated the ABMC. The final portion of Chapter VI explains the aggressive politicization of the ABMC by conservatives. Nixon believed in the power of ABMC sites to instill nationalism in Americans, and became an advocate of the ABMC. Leaders in the ABMC capitalized on Nixon's support, emerged from Congressional attacks intact, and reinvigorated their public affairs program. The ABMC became a conservative ally of the Nixon administration. It sent its commissioners to the battlefields of Vietnam to improve troop morale and created a video for public television explaining the importance of American military sacrifice for international stability. This shift in the 
early 1970 s towards a clearly politicized ABMC and military memory abroad marked the start of a new era in U.S. memory diplomacy. By the end of Vietnam, it was clear that no Cold War remains would be interred in old or new ABMC sites. ABMC sites were effectively frozen in time, but the memory assigned to them continued to change with new administrations and altered international situations. As American military interventions abroad became more controversial at home and abroad from the end of the Cold War through the present, positive memories of American remains from the "good" wars of World War I and World War II continued to serve as a point of entry for scholars to study American foreign policy objectives.

Jay Winter stressed in Sites of Memory, Sites of Mourning, a groundbreaking study of European World War I memory, that historians over stress the political character of war commemoration.34 According to Winter, political studies are useful for improving our general understanding of the symbolic exchanges between the living and the dead, however, overemphasizing the politics of these places erases the true historical meaning of war monuments and cemeteries. Nations, communities, and individuals erected such sites of memory for mourning. Above all else, they served as places the grieving could visit and confront the "brutal facts of death in war." 35 This is a fair assessment. Too much emphasis on the politics of sites of memory does potentially mask the impetus for their creation. But, from an American perspective there is arguably more political motivation behind erection of its commemorative sites abroad than the pragmatic explanation of mourning. The number of Europeans killed and affected by the World Wars dwarfs the United States. Europeans also live much closer

34 Jay Winter, Sites of Memory, Sites of Mourning, 93.

35 Ibid. 
to the actual killing fields. War memorials and cemeteries for European nations surely witnessed larger volumes of grievers. For many Europeans, these pilgrimages are day trips. American cemeteries and memorials abroad harbored and continue to harbor mourners. These sites of mourning are thousands-of-miles away from most grieving Americans, however. Critical analysis of American military cemeteries abroad-from inception to uses-brings Winter's dismissal of political analysis into question. It seems that, while mourning certainly factored into the creation of American cemeteries in Europe, the resources devoted to sites of memory so far from home indicate other motivations. This work acknowledges the mourning factor of American cemeteries, but seeks to explain the something more that they provided the United States. 


\section{Becoming Instruments of Foreign Policy: Utility of American WWI Remains in France}

"These women of France he came to save

Had never known his face or heard his name,

But when they saw the funeral file they came"1

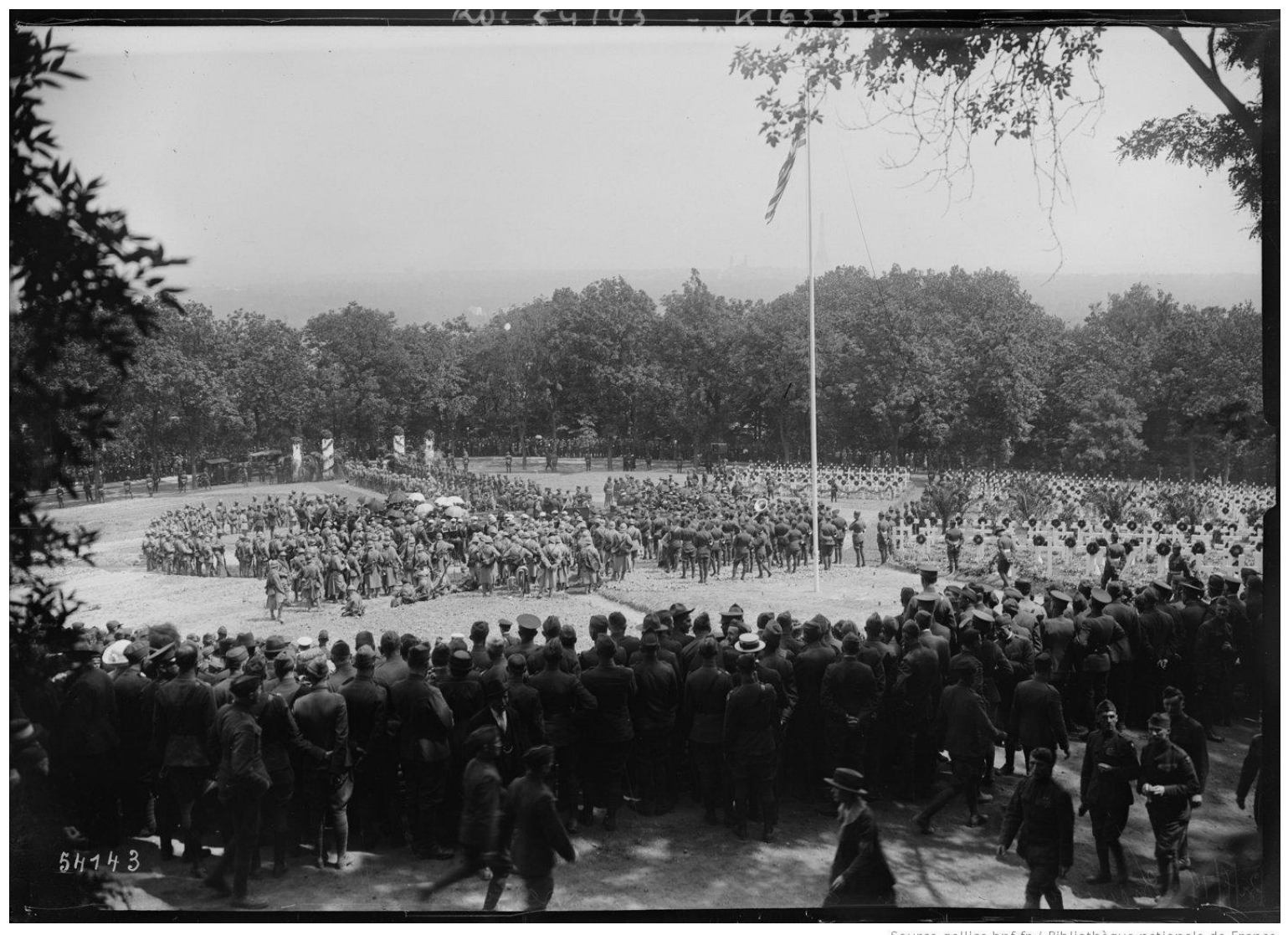

Photo1.1: Memorial Day at Suresnes Cemetery, May 30, 1919. Source: Bibliothèque nationale de France, département Estampes et photographie, online archives.

${ }^{1}$ Ralph Hayes, The Care of the Fallen: A Report to the Secretary of War on American Military Dead Overseas (Washington, 1920), 18. 
On Memorial Day 1919, United States President Woodrow Wilson stepped to the speaker's podium erected at a small American military cemetery in the Parisian suburb of Suresnes cut into Mount Valerien to the city's west. Behind him stood ancient ruins of a French fortress that once defended Paris from invading forces. In the far distance ahead, Wilson saw the Sacré-Cœur Basilica on the heights above Montmartre and the prominent Eiffel far to its right. This commanding view of the city on America's Memorial Day likely seemed fitting to Wilson. He was Commander-in-Chief of the American Expeditionary Forces that tipped the military balance in favor of the Allies and he was the first president to step foot on European soil while in office. Large crowds welcomed him as a hero as he toured the country between meetings with leaders from France and Great Britain to ensure that his Fourteen Point plan might pave the way for a liberal world order of collective security, free trade, and democratically elected governments. Having ended just six months ago, remnants of the Great War remained fresh in the minds of those present. Reminders stood all around. A metallic looking observation balloon used on the Western Front floated nearby; armed French soldiers on horseback formed a perimeter around the ceremony, American doughboys created a sea of khaki before Wilson, and French mothers who found solace caring for American graves wept in the crowd. The most important reminder, however, were the thousand neatly organized white wooden crosses marking American war remains. These dominated the space. ${ }^{2}$

A summer sun, hot enough to cause several female spectators to faint during the ceremony, beat down on Wilson's bare head as he delivered his well-honed thirty-

2 "Soldiers Hear President," New York Times, May 31, 1919, in Proquest Historical Newspapers. 
minute speech. 3 It is possible that the deeply religious and idealistic Wilson felt that this was his foreign policy pulpit to deliver a modern Sermon on the Mount. In the moments before taking the podium, Premier of France George Clemenceau promised the sea of spectators that the French would never forget the memory of Americans who sacrificed all for their country, and that the French would take care of Americans' final resting places "as piously and gratefully as the tombs of our own soldiers." 4 This commitment to remembering American dead was central to Wilson's oration. The site of this speech and presence of American remains held particular significance to Wilson's message. Just days before, the official covenant of Wilson's beloved League of Nations was finalized. It seemed, at last, that the great nations of the world finally established willingness to unite in collective security and enter an era of peace. American remains buried at Suresnes gave Wilson the capital he needed to defend the ideals of the League to the world for the first time.

Throughout Wilson's speech, American remains and the memory of their sacrifices drove his argument for a League of Nations and continued partnership with Western Europe. His speech began by casting the American bodies before him as selfless warriors who entered into a noble crusade, not for the benefit of America, but for all of humanity. He acknowledged Premier Clemenceau's promise and affirmed his belief that "though buried in a foreign land, they [American remains] are not buried in alien soil. They are at home, sleeping with the spirits of those who thought the same thoughts and entertained the same aspirations." 5 He explained that American

3 Cary T. Grayson, "Crusaders, "Peace Conference Diary Entry," May 30, 1919, Cary T. Grayson Papers (digitized), Woodrow Wilson Presidential Library.

4 Ibid.

5 “Soldiers Hear President," New York Times, May 31, 1919, in Proquest Historical Newspapers. Wilson's speech was printed in its entirety the following day in the New York Times. 
servicemen died to give the world the foreign policy "instrument" of the League of Nations to deter future conflicts. Wilson then figuratively called upon the souls of dead Americans to leave their bones and mingle in the audience to pass on an understanding that they sacrificed for "continued liberty and peace." ${ }^{\text {Th }}$ The speech ended with great applause and flowing tears, but initiated a firestorm of controversy within the United States that foretold the ultimate failure of the League. Americans at the time questioned if their soldiers really died for the cause Wilson defined, and if America had any place in the future affairs of France. Even in the present, historians still ponder if the abstract ideas of friendship and shared culture between France and the United States justified an entrance into a conflict that took thousands of American lives.

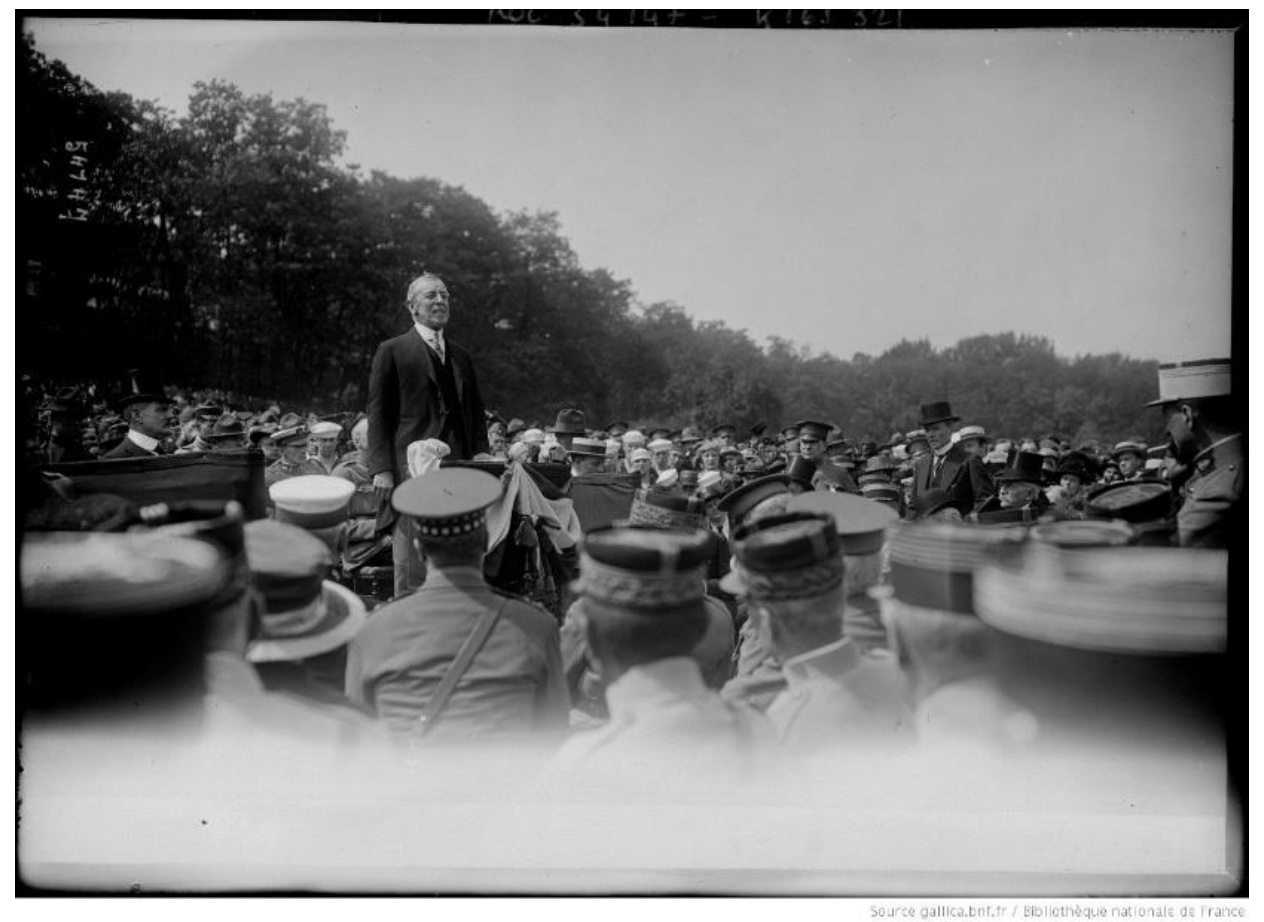

Photo 1.2: Wilson Delivers Suresnes Speech], May 30, 1919. Source: Bibliothèque nationale de France, département Estampes et photographie, online archives.

${ }^{6}$ Ibid. 
On the same day as Wilson's speech, Secretary of War Newton Baker, similarly addressed newly returned American service members at Camp Merritt, New Jersey. Baker also resurrected American bodies buried abroad. He informed the gathered veterans that Memorial Day was partially theirs', but belonged more so to those who remained only as memories. On this first Memorial Day after the Great War, Baker stressed that the dominant characteristic of sacrifice for Americans came from a love for liberty. The prime example of sacrifice was encapsulated by the remains "scattered over the hillsides of France" who, according to Baker, "surrendered their lives gladly and with a smile" for a cause "as high and bold as any man ever died for."7 Baker clarified this cause more clearly as the League of Nations in the upcoming months, telling an audience that if the American dead in isolated graves on the front lines might walk the earth they would surely "march in solid phalanx to Versailles and demand that arrangements be made to forever prevent the possibility of their children ever having to make the same sacrifice as them." 8 The decision of Wilson and Baker to tie the controversial League of Nations so closely with sacred military dead revealed their feelings that the dead possessed the ability to draw support to important foreign policy initiatives.

Republican politicians at home, under the leadership of Senator Henry Cabot Lodge, resented Wilson for excluding them from the Paris peace talks and felt that it was in the best interest of the United States to maintain an isolationist foreign policy. To them, Wilson's League of Nations was a dangerous engagement and not the cause for

\footnotetext{
7 Newton D. Baker, "Memorial Day Address at Camp Merritt, NJ," May 30, 1919, Speech Files, Baker Papers, Box 245, Library of Congress (hereafter LOC).

${ }^{8}$ Newton D. Baker, “A League of Nations: The Demand of the World's Fighting Men" (Chicago: League to Enforce Peace), 10-11. Quoting, "Address of Newton D. Baker at League of Nations Mass Meeting, Tremont Temple, Boston, Saturday Night,” February 8, 1919, Speeches, Baker Papers, Box 245, LOC.
} 
which American soldiers died. Wilson incorrigibly stood up to this opposition, however, and brought the ghosts of Suresnes back to the United States. In a whirlwind national speaking tour from late 1919 through early 1920 Wilson tried to pull American support toward the League by recalling to audiences the presence of the American ghosts in cemeteries abroad. ${ }^{9}$ Wilson's stubbornness to compromise, coupled with a debilitating stroke, dashed all hope of swaying the public and America failed to join his League. Still, the tactics of Wilson's administration opened up a discourse of American sacrifice abroad that entwined France and the United States for the foreseeable future. This discourse of the dead defined American remains as sacred and set the parameters for how American and foreigners should engage with the dead. American military dead became an official symbol, and constant reminder, of America's commitment to France and Western Europe. American and French leaders affirmed this discourse of the dead throughout the interwar years, constantly strengthening it. By the mid 1920s, the discourse was a viable means for activists to level attacks against the governments of France and the United States. American military remains in France, and their memory, seemed forevermore attached to international relations.

Woodrow Wilson's choice to deliver his first public speech defending the League of Nations in an American military cemetery revealed the emergence of collective memory as a serious diplomatic tool, the role of the federal government in commemoration, and new American strategies for creating cultural ties between nations. His remarks at Suresnes initiated a complicated century long relationship

9 Woodrow Wilson, "Wilson's Address in Pueblo, Colorado," September 25, 1919, http://www.firstworldwar.com/source/wilsonspeech league.htm (accessed April 20, 2013). 
between the United States and nations that held its dead. The ways that both Wilson and Clemenceau mutually flaunted their care for the legacy of war dead demonstrated the ability of corpses to link nations together culturally. American soldiers defended France because of shared cultural values-democracy, capitalism, liberty, equality, and Christianity. French soil therefore could hold American military dead because it fostered the same ideologies as America. Mustering support for the League of Nations was the primary objective of Wilson's Suresnes speech. This small moment also provided an effective snapshot of how the United States would place its war remains at the center of commemorative plans and use them as vehicles of foreign policy ideology in the upcoming century.

The scene at Suresnes demonstrates several key elements of this work. First, the event was not wholly American. It was a ceremony rife with cultural transfersrequiring participation of both French and Americans. French cavalry created a perimeter and formalized the event while French mothers mourned in the crowd alongside Americans. One Frenchwoman approached Wilson as he laid a commemorative wreath at the close of his speech and asked him if she might lay her flowers on top of his "as a tribute to the American dead, who, in sacrificing their lives, saved the lives of thousands of Frenchmen."10 Wilson obliged this request while Field Marshal Foch stood by his side visibly moved by the woman's request. ${ }^{11}$ These strong symbols gave validity to French Prime Minister Clemenceau's promise that the French would care for all American military graves as their own. President Wilson then acknowledged this promise on behalf of the predominately American crowd. He went

10 “Soldiers Hear President," New York Times, May 31, 1919. ${ }^{11}$ Ibid. 
on to articulate how a strong French-American relationship might look in the upcoming years. The ceremony established the idea that American military cemeteries acted as sites that bound both countries together. Second, and most importantly, the message delivered by Woodrow Wilson at Suresnes reanimated the American bodies interred in French soil. Wilson's words did not allow the remains to rest in a symbolic void. He resurrected their ghosts and assigned his own meaning to their sacrifice. In Wilson's interpretation, all Americans buried in French soil sacrificed for collective security and love for democracy. Thus, it was the mission of WWI's victors to honor their sacrifice and work together to make sure it was not fruitless. American leaders after Wilson continually assigned meaning to American military dead, as did the French.

Wilson's reanimation of bodies at Suresnes revealed the necessity of manipulating reality for his message to resonate. Familiarity with the Suresnes cemetery shows the artificiality of Wilson's story. He only spoke of the men who rested before him and sacrifices made in the popularly remembered trench fighting. In actuality, Suresnes was one of the worst cemeteries to narrate in this manner. The American remains in Suresnes were the most varied composition of any American military cemetery in Europe. Many were not battle casualties, but victims of Spanish influenza convalescing in hospitals around Paris before ever stepping foot onto the front lines. Among the dead were nurses, civilians, infants, and even suicides. Perhaps the most notable example being twin sisters Dorothy and Gladys Cromwell. Heiresses to millions, the Cromwell sisters forfeited their high society New York City lives to serve as Red Cross nurses in the Great War. Unable to mentally recover from continuous months of service in some of the war's worst battles, the twenty-eight year old sisters held hands and jumped to their deaths in the Garonnes River from their transport vessel 
home. ${ }^{12}$ Wilson completely overlooked the mixture of stories present and created a homogenous narrative of manly combat sacrifice in a holy crusade. ${ }^{13}$ This manipulation of memory, and use of remains, foreshadowed policies that the U.S. government established as it asserted itself within a new international system. The U.S. government meticulously constructed the American commemorative system in which overseas remains eventually went to tell one story of American sacrifice. Ultimately, the memory of U.S. remains abroad reflected aspirations of U.S. foreign policy more so than real international power. This memory would transform from a reflection of aspiration to real power as the century progressed.

\section{Origins of Memory as a Diplomatic Tool}

Assurance that the federal government had American war dead to vocalize required several phases of Congressional legislation. First, the American public needed to decide if they wanted their soldiers' bodies left in Europe. This phase involved heated political and public debate among the many factions within America's diverse democratic society. In this "Progressive Era," a period of broad social reform, the expansion of democratic participation, and government regulation-the final disposition of American bodies was not a unilateral decision of the federal government. Within this debate, some of the biggest issues came down to intentions of the French, economic

\footnotetext{
${ }_{12}$ Maury Paul, “Cromwell Clan Trailed by Jinx," The Milwaukee Sentinel, December 24, 1939.

13 There are many fine international relations studies that use gender as the primary analytical tool. See Kristin Hoganson, Fighting for American Manhood and Consumer's Imperium, Emily Greenberg, Manifest Manhood and the Antebellum American Empire, and Robert Dean, Imperial Brotherhood: Culture Politics, and the Cold War.
} 
costs of repatriation, tourism, and the role of the American and French governments in commemoration. Once evident that considerable numbers of American war remains were staying abroad, an official commemorative plan took shape. Multiple plans came before Congress prior to the creation of an official vision.

For American bodies to retain the symbolic importance that Wilson alluded to in his 1919 Memorial Day address, they needed to remain in France. This was not a foregone conclusion at the time Wilson spoke. Americans who sent loved ones abroad to make the world safe for democracy fully understood that they might not survive the endeavor. Worried families found some solace in the fact that Americans killed on islands of the Caribbean and Pacific Basin during the War of 1898, in the Filipino Insurrection, and the Boxer Rebellion came home for burial. Even more comforting was a promise by Secretary of War Newtown Baker in September 1918 that the United States government would ensure a home burial to all who died in its foreign service. ${ }^{14}$ Baker surely did not anticipate the heated debate that his promise eventually brought. American participation in the Great War dwarfed all other American foreign engagements. Dead American service members quickly became a problem for high command. Filling up precious cargo space with corpses, caskets, and burial equipment on the transatlantic voyage while waging war was not feasible. To the likely dismay of many American families, General Pershing ordered the interment of all dead Americans in European soil until hostilities ended. ${ }^{15}$ The end of hostilities still did not bring a quick return of remains. Because most of France's infrastructure and industry was

\footnotetext{
14 Ralph Hayes, Care of the Fallen: A Report to the Secretary of War on American Military Dead Overseas (Washington, DC: 1920), 11. See also Lisa Budreau, Bodies of War, 21 and "Bring Back Our Dead," New York Times, September 5, 1918, in Proquest Historical Newspapers.

${ }^{15}$ Hayes, Care of the Fallen, 20.
} 
destroyed in the war, and from fear of spreading infectious diseases, the French government passed a law prohibiting all exhumations of war dead in France for three years. Many Americans viewed the French denial of their loved one's remains as the ultimate treachery and threatened Washington of taking repatriation matters into their own hands unless immediate action was taken. A mother from Brooklyn made the following demand to the State Department in 1920: "No matter what happens I want my dead son brought home to me at once even if I have to go over and get my son myself." 16 Other mothers took the opposite stance and felt that their deceased bodies should continue to serve America. Mathilda Burling, a grieving New York mother and vocal advocate for state sponsored pilgrimages for mothers to visit their son's graves, took a stance quite opposite of the Brooklyn mother. Burling initially wanted her son's remains brought back from France, but claimed that former President Theodore Roosevelt swayed her opinion by personally writing her with a plea to "leave your boy where he fell" because that is what all soldiers wanted. ${ }^{17}$

The forced delay of repatriation had profound effects on both the French and Americans. In the aftermath of World War I, American sentiment divided on the question of repatriation. Many Americans held Newton Baker to his promise and waited for the return of their loved one so they might find closure. Yet, as time passed and the American government assessed its repatriation policy, feasible alternatives to total repatriation emerged. Removing all American soldier dead from Europe was a logistical

\footnotetext{
${ }_{16}$ Margaret Vascinini (sp?) to Robert Lansing, March 1, 1920, Box 4202, Bring Home the Soldier Dead Folder, Department of State, Decimal Files, 1910-1929, RG 59, NARA.

17 Testimony of Mathilda Burling, "Hearing Before A Subcommittee of the Committee on Military Affairs United States Senate, Seventieth Congress, First Session, on H.R. 5494, Bill to Enable the Mothers and Unmarried Widows of the Deceased Soldiers, Sailors, and Marines of the American Forces Interred in the Cemeteries of Europe to Make a Pilgrimage to these Cemeteries," February 12, 1929 (Washington, DC: Government Printing Office, 1928), Part II, 25.
} 
nightmare projected to cost the United States millions of dollars. ${ }^{18}$ The high cost of repatriation was not the only cause of reconsidered policy. American leaders, backed by the views of General Pershing, realized that the repatriation of all American dead meant the possible erasure of American sacrifice from mankind's memory of the Great War. France's hero of Verdun, Marshal Pétain, helped show Pershing a vision of American military cemeteries shortly after the war when he wrote to Pershing that American "fields of honor" should be established in France and that "France would be happy and proud to retain the bodies of American victims who had fallen on her soil."19 Pershing knew that, although of great importance, American participation in the war dwindled in comparison to European nations. He also saw the unfolding British policy of leaving all its soldier dead in battlefield cemeteries, and the French erection of national cemeteries. Physical reminders needed to stand alongside those of associated partners if the world was to remember American sacrifice in WWI. Not long after the war Pershing cabled Washington with his thoughts on where his soldiers should rest. If the dead Americans "could speak for themselves, they would wish to be left undisturbed with their comrades," Pershing opined. ${ }^{20} \mathrm{He}$ added that remains could serve as "a perpetual reminder to our allies of the liberty and ideals upon which the greatness of America rests." ${ }^{21}$ The final recommendation from the victorious general was that "none of our dead be removed from Europe.”22 Immediately following the war Pershing assigned

\footnotetext{
18 The final bill was around thirty-million dollars.

19 Hayes, The Care of the Fallen, 23.

${ }^{20}$ Ibid., 24.

${ }^{21}$ Ibid.

22 Ibid.
} 
members of his staff to begin recording the official history of America's part in the Great War, and ordered them to begin forming an American commemorative plan. ${ }^{23}$

Pershing understood the power that physical reminders played in securing the legacy of sacrifice in war. He envisioned a memorial landscape in the immediate aftermath of the war characterized by European and American sites of memory standing side-by-side. Pershing was dismayed to see American units haphazardly placing their own rudimentary memorials on the French landscape. He often felt that these memorials overly exaggerated the role that small units played in combat, diminished the memory of a unified American military effort, and offended local inhabitants. To combat this, Pershing wrote the U.S. Army Chief of Staff in 1919 asking that the federal government take steps to control designs of U.S. monuments so that they not risk giving “diplomatic offense.”24 Diplomatic offense was a very real concern. In 1921, a private American organization raised funds to purchase thirty-square feet of Parisian realty across from the Arc de Triomphe for the purpose of placing a billboard with the words, "We are it." 25 This American arrogance and "belittling" of a sacred French site thankfully never reached fruition. ${ }^{26}$ Ironically, evidence shows that Pershing's draconian measures actually offended the French more than the memorials themselves. As the American government, through the War Department initially, attempted to control American commemoration in France, French communities often protested. The

23 "Memorandum to Chief of Staff regarding marking of battlefields in Europe from Assistant Chief of Staff Major General Haan," May 16, 1921, Box 1, Records of the ABMC, Final Report of Battle Monuments Board, RG 117, NARA.

24 "Cablegram from Pershing to the Chief of Staff," June 18, 1918, Box 1, Entry 1, Final Report of Battle Monuments Board, RG 117, NARA. Original emphasis.

${ }^{25}$ Hearings before the Committee on Foreign Affairs House of Representatives Sixty-Seventh Congress on H.R. 9634 and H.R. 10801 for the Creation of an American Battle Monuments Commission, March 15-20, November 28, December 7-9, 1922 (Washington, DC: Government Printing Office, 1922), 14. ${ }^{26}$ Ibid., 15 . 
removal of American monuments that Washington deemed undesirable to the national narrative from small French towns often angered inhabitants. A small village in the Meuse region of France protested against General Pershing in 1930 when he ordered the removal of a memorial placed by the American $361^{\text {st }}$ Regiment in their town. The villagers lodged a complaint with the French government to resist Pershing's demands because they felt pride for their memorial and their American comrades. ${ }^{27}$ Episodes like this were common and often complicated. Many French towns came to view their small American memorials fondly and felt a duty to maintain them, even long after memorial maintenance funds from privately backed monuments waned.

The notion of diplomacy in the construction of memorials is not empty rhetoric. A key element of good monumentation is its ability to withstand the rigors of time. The men assigned to General Pershing's initial Battle Board, which became the American Battle Monuments Commission, understood the permanency of monuments and the reality that Americans would engage with the monuments on tours, but the French would live among them. Therefore, careful thought needed to go into the selection of each American monument. The monuments had to tell a balanced story of all American participants in the war, needed to show the unity of the American people, and needed to be inoffensive to the French. Different perspectives on these sentiments came in the Congressional hearings leading up to the creation of the ABMC.

Much of the testimony before Congress from proponents of a permanent memorial commission addressed the need to stop states and private individuals from working with the French outside of official American diplomatic channels to place

27 "French Group Resists Pershing on Memorial," New York Times, August 12, 1930, in Proquest Historic Newspapers. 
monuments on American battlefields. These monuments created an unbalanced interpretation of American service in WWI-one that mainly reflected the depth of one's pocketbook. In this modern era, the federal government possessed the ability to stop the oversaturation of memorials in France. American battlefields of the future would not resemble the monument fields of Antietam or Gettysburg. Members of Pershing's commemoration board extensively toured Antietam battlefield in Sharpsburg, Maryland to learn what to avoid on America's WWI battlefields. Going even further, Congress felt that, in modern America, "the public should not be bothered" about erecting monuments because it was now "clearly the duty of the Government to erect suitable memorials to its soldiers." 28 This sentiment reflects the gradual increase in power of the federal government following the Civil War into the industrial age.

Another prominent feature of testimony for a monuments commission dealt with the international nature of such a commission's work. Many of the participants in the hearings stressed Pershing's early view that monumentation of the Great War was primarily a diplomatic undertaking. In order to prevent American donors from creating "disreputable, belittling, or hideous" monuments, the new commission needed among its membership at least one individual with an understanding of French culture. ${ }^{29}$ Several speakers in the Congressional hearings called on Congress to show prescience and accept the inevitability of "contentions" between France and the United States as lengthy memorial construction projects began. $3^{30}$ Fear of contentious periods compelled several testifiers to call for inclusion of the Secretary of State Robert Lansing and the

\footnotetext{
${ }^{28}$ Sentiments of Stephen G. Porter, House Chairman of Committee on Foreign Affairs, from ABMC Hearings, 10-11.

29 Ibid., 15-16.

30 Ibid., 13.
} 
American ambassador to France, Hugh Wallace to work on the commission. These men had the best chance of understanding French tastes and knew how to engage in the diplomatic negotiations required in the acquisition of French land, labor, partnerships, and approval. $3^{1}$

These prominent diplomatic officials never joined the commission. Their absence is likely explained by Pershing's chairmanship of the commission. Being a career soldier, Pershing kept membership primarily in the realm of veterans. Also, Pershing was as a Francophile who spent nearly half of each year of his retirement in France socializing with the country's premier citizens and his much younger French companion. Pershing's commission also maintained a Paris office in the interwar years that was first within the American embassy itself, and then in property owned by the embassy. This arrangement kept the ABMC in close contact with American diplomatic channels. By all accounts, the ABMC's World War I memorial plan succeeded at not offending French sensibilities. The Commission worked closely with the Commission of Fine Arts to contract reputable American architectural firms, who appointed trusted sculptors. Among the ABMC's closest advisors during World War I construction was respected American architect Paul Cret. ${ }^{2}$ ABMC commissioners, Cret, and the Commission of Fine Arts reviewed the plans of all architects, voted their approval, and offered their revisions. The ABMC's sites of memory and shrines to the dead indeed "impressed, but did not annoy" foreign hosts. 33 Some argue, however, that the ABMC's

\footnotetext{
${ }^{31}$ Ibid., 13-17.

${ }^{32}$ Cret believed that monuments should retain "imperious overtones of classicism" while avoiding facsimile of Athens and Rome. Essentially, Cret was an architect of comprise, meshing tradition with modernism. Some of his most noted works are the Folger Shakespeare Library, Federal Reserve Building, and Bethesda Naval Medical Center.

33 Ron Robin, Enclaves of America: The Rhetoric of American Political Culture Abroad, 19oo-1965

(Princeton: Princeton University Press, 1992), 53.
} 
efforts to erect diplomatically suitable shrines masked the true United States. Instead of depicting a diverse, politically fractured, industrialized, and mass culture society, the ABMC put forth a representation of an anachronistic, preindustrial, and traditional America unrecognizable to Americans almost immediately after construction ended. 34

Shortly after WWI it was discovered that the most effective monuments, in terms of emotional power and desirability to visit, were the dead themselves. The testimony of Walter McCoy, Chief Justice of D.C.'s Supreme Court, demonstrated the importance of American remains in the Congressional hearings to establish the ABMC. McCoy accurately foretold the centrality of U.S. cemeteries in the war commemoration effort and warned Congress that present care for military cemeteries lagged far behind other allied powers. Citing a recent report from the U.S. Commission of Fine Arts regarding the state of U.S. cemeteries in Europe, McCoy brought focus to the importance of cemeteries in commemoration. The report told of the flagging condition of U.S. soldiers' final resting places in France. As it were, cemeteries appeared as "handkerchief's spread out on the grass to dry," their small white spot making no "vital relation to the great expanse of rolling country.”35 Visitors to American cemeteries, thus, had no chance of putting context to the visual sacrifice before them. The cemeteries lacked connection to their nearest towns, the white cross tombstones sat in dull squares, and the cemeteries possessed a feeling of temporariness. ${ }^{36}$ McCoy urged the future ABMC to catch up with

\footnotetext{
34 Ibid., 57-60. Robin argues that the ABMC's push to portray America as a romanticized anachronistic society in order to not displease its allies ultimately made its Great War monuments incapable of resounding with Americans in subsequent generations.

35 "Hearings Before the Committee on Foreign Affairs, House of Representatives, Sixty-Seventh Congress, Second and Third Sessions on H.R. 9634 and H.R. 10801 for The Creation of an American Battle Monuments Commission to Erect Suitable Memorials Commemorating the Services of the American Soldier in Europe," March 15-20, November 28, December 7-9, 1922 (Washington, D.C.: Government Printing Office, 1922). 40.

${ }^{36}$ Ibid.
} 
Great Britain and France in regards to worthy commemoration. 37 Cemeteries, not battlefield memorials needed to be the priority of the U.S. government. Judge McCoy offered great foresight, stating that if "there is any monument in France that can ever be erected on the battlefields to compare for sentiment with a cemetery, then it will take a greater genius in art than I believe the world possesses. Those are the monuments in France, those cemeteries that will stand for most and be visited by the most people from this country." 38

Justice McCoy's friend, and gold star father, attorney Fred Bentley from Chicago furthered McCoy's cause during the next day's hearings. Bentley presented to the House Committee on Foreign Affairs amendments to the ABMC legislation framed on McCoy's argument. These amendments explicitly categorized "military cemeteries on foreign soil as battle monuments" in themselves. 39 As memorials, it ultimately fell upon the ABMC to "inspire in the people of Europe" the lofty and unselfish purpose of America in waging war" on their soil.40 Bentley went on to explain the evolution of cemeteries in the years immediately following the war. Some 52,000 Americans stimulated by "the fire of war" and patriotism chose to give the "ashes" of their fallen Americans to a "great European monument." ${ }^{41}$ Americans initially believed that all of the sacrificed remains were going to a single European cemetery-Suresnes was the likely frontrunner. Early reports from U.S. bureaucrats assessing permanent burial sites noted that the Suresnes cemetery was one of the "most conspicuous landmarks in the environs of Paris" and that

\footnotetext{
37 Ibid., 40.

${ }^{38}$ Ibid., 41, 42.

39 Ibid., 51.

40 Ibid.

${ }^{41}$ Ibid.
} 
it was "to be the gem among the American cemeteries." 42 Wilson had already shown the political uses a cemetery so close to Paris offered. Pershing's military team and Secretary of War Baker abandoned the single cemetery model rather quickly. A single depository of American dead slighted American military sacrifices in countries other than France. Cemeteries brought visitors, and the dead physically showed them American sacrifice. Cemeteries became the primary monuments of major battlefields and American remains were accordingly exhumed and distributed through eight cemeteries-six in France, one in Belgium, and one in England. 43

Classifying American military cemeteries as monuments is an important distinction. America's cemeteries from the Great War were, from the very beginning, considered monuments to mark battlefields. The resting places of American soldiers in Europe were certainly cemeteries, but it was the intention of the federal government for them to quickly elevate to more. Cemeteries often connote feelings of active spaces. Humans continually die and the living place them in cemeteries. The death of Americans abroad from wounds received in the Great War was more-or-less over within a year after the armistice. Additionally, once families decided on final resting places, interments ended. These factors made American military cemeteries completed projects. The placement of the final tombstone and planting of the final greenery transformed American resting places from cemeteries to monuments. Any person unfamiliar with the American Battle Monuments Commission likely has no idea what function they actually perform on behalf of the American public because their name is a misnomer. It is suggested nowhere in their name that remains or graves are cared for.

\footnotetext{
42 "Report by Mr. Charles Moore, Chairman of the Commission of Fine Arts, July-September, 1923," Box 4, Entry 17, RG 66, NARA. 43 Ibid.
} 
That is, unless it is understood that cemeteries are considered monuments. Although never explicitly stated, $\mathrm{ABMC}$ cemeteries are monuments, so are the graves that compose the cemetery.

\section{American Bodies in French Soil?}

The final disposition of American remains was not settled neatly when the ink on a military order or piece of legislation dried. Nor was the debate exclusively limited to Americans. French President Clemenceau's 1919 Memorial Day promise that opened this chapter indicated that American sacrifices would live in perpetuity in French minds, and that they would take care of Americans' final resting places "as piously and gratefully as the tombs of their own soldiers." 44 This might sound to some like the hollow rhetoric of a political leader looking for favorable treatment by America in a time of great French need. Yet, evidence shows more sincerity than emptiness in French hearts in the years immediately following war. Many French citizens living close to battlefields desired having small American memorials in their towns, but their reverence for American military remains dwarfed this. During the war, immediately after, and through much of the interwar period, a large portion of France venerated American graves. Numerous accounts exist in news stories and personal reminisces about how the French demonstrated their gratitude for American sacrifice through care for American remains. Americans frequently read stories of French school children visiting American military graves, or French women adopting graves and placing cards on American tombs

44 “Soldiers Hear President,” New York Times, May 31, 1919, in Proquest Historical Newspapers. 
that read "Adoptee par Madame ..."45 Even when French animosity towards America and Americans increased during the interwar years, as the next chapter shows, most of the French easily saw that dead American veterans had little to do with contemporary American policies-despite American officials' attempts to animate them to do so.

Ample evidence of French reverence towards American remains exists in records left by grateful Americans serving in various capacities overseas. They witnessed firsthand French adoration for American dead. Woodrow Wilson is himself an example of this. Upon returning from the Paris Peace talks, he frequently used his observations about French reverence for American dead as justification to leave remains abroad and as evidence that the U.S. belonged in the League of Nations. Wilson told crowds of a common practice he witnessed of Frenchwomen adopting American graves and making themselves "mothers of those dear ghosts by putting flowers everyday upon those graves, taking them as their own sons." 46 He reassured crowds that if Americans could see such care and allow the "thought that comes out of those graves to penetrate their consciousness," they would feel a moral obligation to take a place alongside other nations in a new world order.47 According to the first American cemetery superintendent at Suresnes, "the weather never became sufficiently stormy to stop the coming of the townsfolk, or their caring for the grave plots of Americans." 48

A similar observation came from Mary Watkins, an American nurse in wartime France. Watkins cited her firsthand experiences in Europe to The New York Times

\footnotetext{
45 Women in Paris Tend U.S. Grave," The New York Times, October 20, 1918, in Proquest Historical Newspapers.

46 Woodrow Wilson, "Speech at Peublo, CO," September 25, 1919,

http://www.firstworldwar.com/source/wilsonspeech league.htm, :accessed April 20, 2013).

47 Ibid.

${ }^{48}$ Hayes, The Care of the Fallen, 18.
} 
urging mourning Americans to consider leaving their fallen to the care of the French. While travelling through small French towns on the Western Front she witnessed an old man who returned to his ruined home to find the grave of three Americans in his garden. The impoverished farmer considered the Americans honored guests, decorated their gravestone with his rosary (the only possession he kept during his flight to safety), and prayed over their graves daily in thanks of their help liberating his small plot of land. He was devastated when the Graves Registration Service removed the bodies to another burial site. Similarly, Watkins told of a comrade who returned to one of her old aide stations the Memorial Day after the war to find a hillside of American graves looking like "one mass of blossoms" because the entire town uprooted every flower in their gardens to place on American graves. ${ }^{49}$ French children similarly showed veneration for American dead through their school curriculum. French schools submitted essays their children wrote to the Fraternite Franco-Americaine who then published them in America and France. A seven-year old French girl's essay appeared in the American press. She told of walking in the cemetery with her mother on Sundays and putting bouquets of flowers on American graves and pulling out any weeds she encountered." 50

In the final month of World War I, Secretary of War Newton D. Baker recounted to an audience of prospective American war loan buyers interviews with French children that he recently read in the magazine The Independent. Interviewers questioned French children about their feelings towards American soldiers for this article. Baker reported

\footnotetext{
49 Mary Watkins, "Our Dead In France,” New York Times, April 20, 1921, in Proquest Historical Newspapers.

50 "America as seen by French Children," New York Times, March 18, 1923, in Proquest Historical Newspapers.
} 
the following glowing examples of amicability: "he is large and brave...very generous, he helps cut the kindling wood, he draws water for us at our house, they are learning French from us, they have come across the water to help our country and we love them." ${ }^{11}$ Baker saw the viewpoint of a French child as the unfiltered and genuine view of all French people towards Americans. Baker obviously chose these example in hopes of selling war bonds, but the continuation of this perception from Baker after the war suggests genuine belief in Franco-American camaraderie. If the French showed such reverence for American doughboys in life, surely these sentiments could only grow in death.

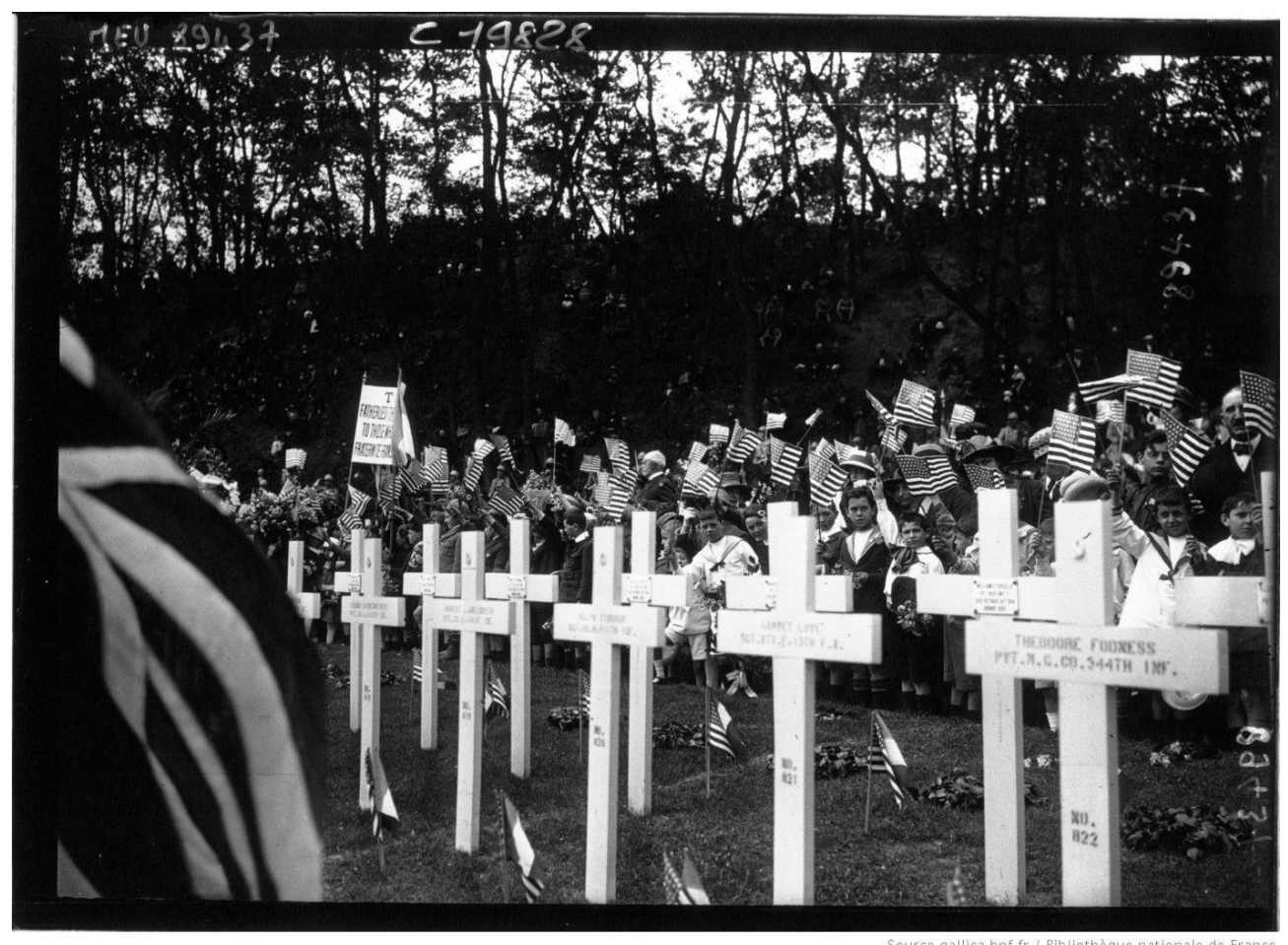

Photo1.3: French Children with American Flags in Suresnes American Cemetery, May 1921. Source: Bibliothèque nationale de France, département Estampes et photographie, online archives.

${ }^{51}$ Newton D. Baker, "Address Delivered by Secretary of War Newton D. Baker, Saturday October 19, 1918 at 13:30 P.M. at the Southern Hotel on the Occasion for a Meeting Held for the Fourth Liberty Loan," Box 245, Baker Papers, LOC. 
Some French historians argue that anti-Americanism went through its "golden age" during the interwar years. $5^{2}$ Evidenced by the fact that the "wreaths woven for the boys of the Argonne and Saint-Mihiel had hardly wilted when reproaches and accusations began shooting off in France." ${ }_{3}$ The spirit of cooperation to defeat the Central Powers gave way to transatlantic misunderstandings before the blood of the Western Front dried.54 This assessment holds some truth, although it needs slight amendment. Evidence shows that major animosities between the two countries did not take place until later in the 1920 s when unpopular American war debt policies and radicalized political protest became the norm in Paris. In the years immediately following the Great War, as America constructed its national memory and discourse of military dead on French soil, misunderstandings between nations remained minor. Misunderstandings that did exist frequently dealt with the remarkably different war experience of each country.

The devastation that World War I brought to France cannot be overstated. The most fighting was on French soil and France lost nearly five times the soldier dead in its lengthy battle of Verdun than the United States lost in the entirety of its WWI experience. The French economy was ravaged, the populous collectively grieving, and the government anxious to protect its borders from future invasion in the immediate aftermath of the war. Secretary of War Baker captured the melancholy of France in observations he made during his visit to the country in 1918 as the final offensive

\footnotetext{
$5^{2}$ Philippe Roger, The American Enemy (Chicago: University of Chicago Press, 2005), 214. 53 Ibid., 259.

54 Ibid.
} 
launched, "all the women wear mourning, and even the girls wear mourning, from about ten years old up. The country is draped in black. I cannot now remember that I saw a single dress of white, or any color, except black." 55 Still, he went on to note that "the spirit of the country is wholly unbroken." ${ }^{6}$ It is in this atmosphere of unremitting grief that the French government faced bombardment from Americans over their " 56,000 human lives instead of our 1,356,000." 57 France's most pressing goal was not to focus on the dead, but the living. President Paul Deschanel summed up his answer to France's post-war problems in 1920, "in order to solve our social, constitutional, educational, economic, and diplomatic problems, before anything else, we must live. Hence, France should fight against her low birth rate. Youth, happy youth, must lead the way." ${ }^{8}$ The

55 Newton D. Baker, "Making the Soldier Fit to Fight," December 5, 1918, Box 245, Baker Papers, LOC. Quote from page 16.

$5^{6}$ Ibid.

57 Roger, American Enemy, 263. Roger is quoting former Premier Georges Clemenceau, Grandeur and Misery of Victory (London: George F. Harrap, 1930), 165.

${ }_{58}^{8}$ The Independent, February 14, 1920, quoting French President Paul Deschanel,, "A Message from the French Republic,” Box 245, Baker Papers, LOC. Italics added by author. 
way to lift the black shroud covering the country was through living.

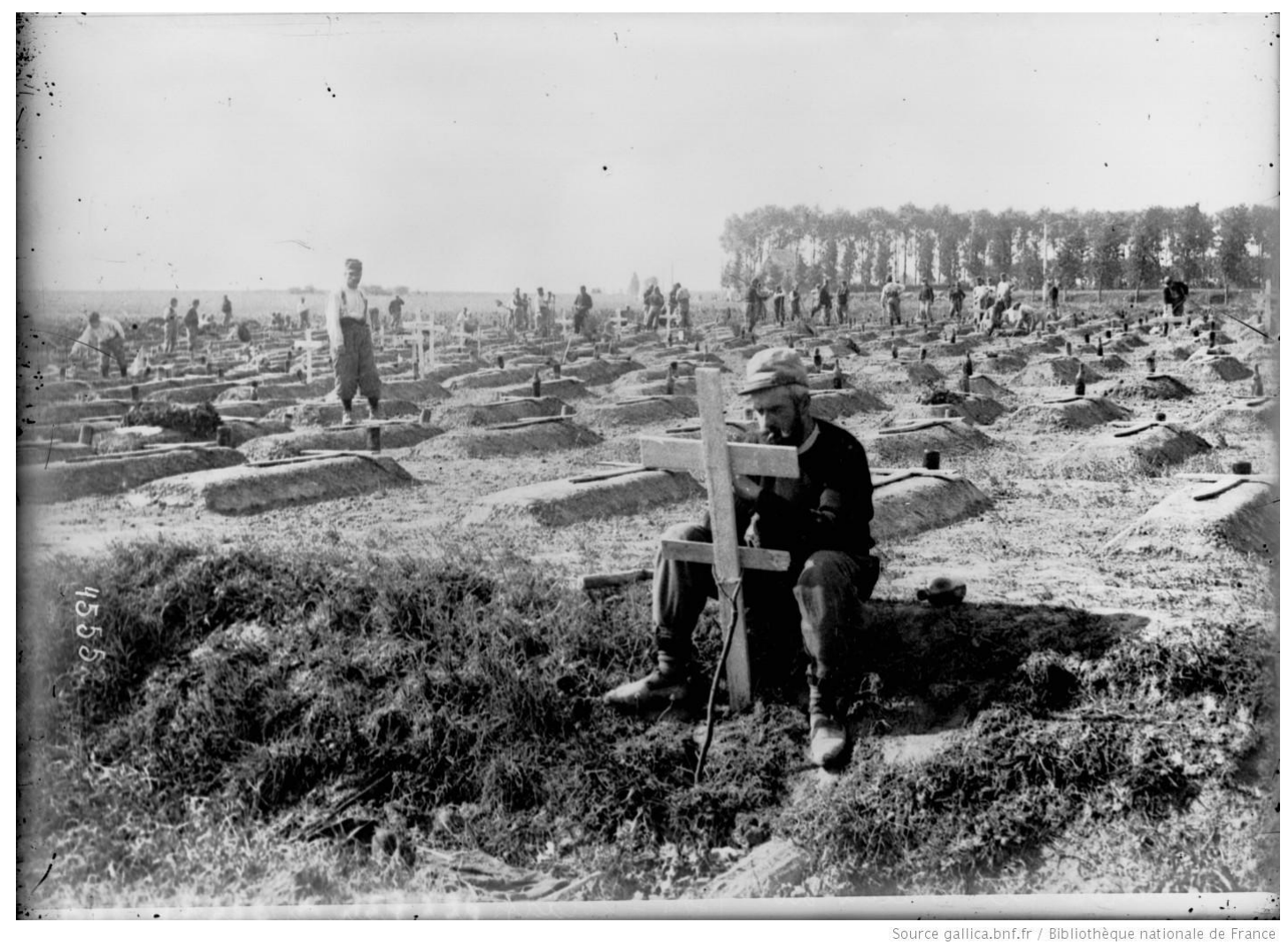

Figure1.4: French Soldier annotating cross at Cemetery de Villers-aux-Bois, 1915. Source: Bibliothèque nationale de France, département Estampes et photographie, online archives.

Looking at the French perspective in this light shows the rationality behind the nation's late 1918 decision to prohibit all exhumations from its soil for three years. The French government, at the war's conclusion, estimated that the bodies of some 4.5 million soldiers decomposed in its soil. French officials opted to keep these bodies where they rested for three years following January 1, 1919 for several reasons. First, after four years of French mourning throughout WWI, the immediate exhumation of corpses would only prolong emotional depression and prohibit reconstruction. French leaders felt that the constant movement of exhumation materials eastward and corpses westward would extinguish the flickering morale among the people. Second, large scale 
removal of fresh corpses posed immediate threat of epidemic and pestilence. And finally, it seemed unfair to French mourners to allow foreign nations to return their dead while France was in no position to do so itself.59 France was, however, willing to help other nations obtain permanent cemeteries for its dead on their soil while the three year ban existed. Accounts from ABMC officials showed a willingness of French landowners to give the $\mathrm{ABMC}$ fair land prices for monuments, even though negotiations required bribery with barrels of wine in some instances. ${ }^{60}$ France's reasoning for exhumation restrictions seems completely logical. Nevertheless, the reception of this news initiated outrage in many American households. ${ }^{61}$

Americans attacked France's exhumation policies vehemently and often with a complete lack of humility. How could the French nation, which owed its very survival to the American soldier, deny Americans their bodies? Enough American protest reached the departments of State and War to force Washington to direct American diplomats to sway the minds of French representatives. American diplomats appealed to the French government with tact. They argued that, unlike European belligerents, American mourners lacked easy access to battlefields and cemeteries. A grieving European mother's trip to a grave was a short ride by train or automobile, while a grieving American's involved weeks of expensive travel.62 American diplomats also offered the French government an explanation it might give to its people to rationalize repatriation

\footnotetext{
59 "France Bars Moving All Soldier Dead," New York Times, July 30, 1919, in Proquest Historical Newspapers.

60 Thomas North, One Soldier's Job, (American Battle Monuments Commission: unpublished, undated), I-16, I-18.

${ }^{61}$ For an excellent summation of France's postwar dealings with its dead see Part I of Jay Winter, Sites of Memory, Sites of Mourning: The Great War in European Cultural History (Cambridge: Cambridge University Press, 1995).

62 Hayes, The Care of the Fallen, 25.
} 
of American bodies. Of the 5,000,000 military dead in France, only a "small number were American soldiers."63 Allowing the removal of this small segment of dead surely could not "seriously embarrass the French government." ${ }^{4}$ America's appeals eventually swayed the French legislature and the three year exhumation ban was shortened.

Episodes of French care for American graves was already not adequate justification to many Americans for leaving war dead in alien soil even before France restricted exhumations. Some Americans bitterly opposed any attempts to keep American dead abroad and formed groups like the "Bring Home Our Soldier Dead League.” These associations viewed the French negatively and saw French antiexhumation legislation as despicable. Where proponents of leaving remains abroad saw genuine care, groups who wanted remains brought home saw exploitation. Members of the Bring Home the Soldier Dead League bombarded Secretary of State Robert Lansing with letters demanding the arrangement of return for all American dead. Ella Boyd of Pittsburgh attested that she only demanded "what rightfully belonged to her [her son's corpse]" and that their fallen soldiers should rest in the "country they fought so bravely for" not "France, where they never thought to lay." Mrs. Boyd lamented to Secretary Lansing that she could rest only when her son was home.65 Another mother from Pennsylvania provided a similar plea, "It is not so [that] they would wish their remains to lie on foreign soil could they speak for themselves. My own dear son who was but 17 years of age wrote (Mother, I'll be glad when we're all together again, just wait patiently,

\footnotetext{
63 Ibid., 25.

64 Ibid.

65 Ella Boyd to Robert Lansing, January 11, 1920, Box 4202, Department of State, Central Decimal 19101929, War Dead, RG 59, NARA.
} 
I'll be home)."66 The State Department was inundated with similar letters following France's exhumation stoppage. The standardized response to these parents was sympathy and assurance that Secretary Lansing had initiated "diplomatic negotiations" with Paris to get the corpses moving again. ${ }^{67}$

Many parents writing to the State Department requested only that their family member return home, providing no impetus. Perhaps just as many went a step further and vocalized their main motivation for repatriation. Many parents viewed France's exhumation stoppage as nothing more than an economically motivated measure to hold American corpses hostage as tourist traps. The mother of Lee Ackerman, a runner for the $319^{\text {th }}$ Infantry, wrote from Homestead, PA that her son had done all a human can do for his country. She begged the United States to "not allow France to make them [soldier dead] the attractions of tourists," and cruelly turn her son's resting place into a means to make money. ${ }^{68}$ In the same year, a grieving widow from Beardstown, Illinois castigated the State Department for bending to France's will. She informed Secretary of State Robert Lansing that it was “America's sacred duty" to keep the promise made to bring home all bodies and added that it was "not for France to dictate to America" the policy of their own soldier dead. ${ }^{69}$ Another Pennsylvania mother begged Lansing to "not allow France to have her Paul's body for sightseeing." She put her "trust in God that America may soon receive the bodies of our boys."70

\footnotetext{
66 Mrs. Laura May Beltz to Robert Lansing, January 11, 1920, Box 4202, Department of State, Central Decimal 1910-1929, War Dead, RG 59, NARA.

${ }_{67}$ Robert Lansing to Ella Boyd, March 25, 1920, Box 4202, Department of State, Central Decimal 19101929, War Dead, RG 59, NARA. 68 Mrs. Ackerman to Robert Lansing, January 11, 1920, Box 4202, Department of State, Central Decimal 1910-1929, War Dead, RG 59, NARA.

69 Name ineligible to Robert Lansing, March 2, 1929, Box 4202, Department of State, Central Decimal 1910-1929, War Dead, RG 59, NARA.

70 Mother of Paul E. Bills to Lansing, January 10, 1920, Box 4202, Department of State, Central Decimal 1910-1929, War Dead, RG 59, NARA.
} 
Multiple aspects of American animosity towards leaving American soldier dead abroad came from W.A. Beunle, a father from Pittsburgh. Beunle rhetorically posed the following question to Secretary Lansing, "he was an American with American blood running through his veins, why should he be deserted by us and our government and left sleeping on the other side?" He then indicted that American social inequality as the reason his son's body was stuck in France. It was wealthy Americans who sacrificed nothing in the war that wanted American corpses left abroad in Buenle's mind. "As the old saying of some of these birds (not men) who did not lose anybody in the war goes, 'Let them sleep where they fell.' This saying is not the truth.” Finally, Buenle's wrath turned to the greedy French. From his assessment, "the majority of the bodies have been removed and placed in a large plot where hotels are being built to accommodate the tourists." The majority of tourists being "the rich people who lost none but just for curiosity sake [go to France] to see the ruins and brave boys who lost their lives." In the meantime, Americans like Buenle, "the poor people (yes the poor) can stay at home and look at the picture and never have an opportunity to lay one flower on his or her grave." 71 This is a truly heartbreaking assessment of the repatriation issue that shows reverberations in people's lives. His letter reveals that Buenle felt helpless from his selfdescribed position as a poor man in a seemingly unforgiving domestic and international system. Thankfully, a coffin eventually made its way back to the Buenle's in Pittsburgh.

As moving as some of these American petitions to the State Department are, many of their attacks appear misplaced and driven by more emotion than rationality. It is certain that American corpses in French soil would bring Yankee dollars. A study by

\footnotetext{
${ }^{71}$ Mr. and Mrs. W.A. Buenle to Lansing, January 10, 1920, Box 4202, Department of State, Central Decimal 1910-1929, War Dead, RG 59, NARA.
} 
the War Department acknowledged the certainty that "extortion and profiteering might be found among merchants and innkeepers in the vicinity of some of the hundreds of American burial places in France." 72 The desire to make money when an opportunity showed itself was inherent in human nature. However, on the whole, the War Department found that it was "not true that there exists now in France any generally prevalent effort to capitalize financially on American burial places."73 If anything, the French had shown opposition to American tourism to battlefields and cemeteries because those excursions wasted coal and gasoline that was in short supply throughout France. 74 Archival evidence suggests that, if anyone was tying tourism to American cemeteries, it was the American government. American parents wary of having their boy's or daughter's body frequented by tourists largely had policies of their own government to blame.

\section{$\underline{\text { Bodies as Tourist Attractions }}$}

The desire to draw Americans into France to experience the sacrifice displayed in their military cemeteries commonly revealed itself in the early commemorative plans. The emergence of America as a modern-nation state largely explains this.

Industrialization in the United States brought rapid technological advancements. These advancements drastically altered traditional American culture. At the start of the

\footnotetext{
${ }^{72}$ Hayes, The Care of the Fallen, 15.

73 Ibid.

74 Ibid., 27.
} 
twentieth century, America rapidly evolved from a land of island communities into an integrated nation with a mass culture.75 Tourism emerged as an integral piece of this new culture. Throughout the early twentieth century a more powerful federal government, prosperity, and transportation developments brought improved infrastructure that drastically shrank Americans' world. Some consider the interwar years the birth of the modern American tourist industry. Tourism in this period went far beyond the modern phenomenon of paying for an experience that not everyone has access to. Americans viewed touring an essential part of discovering their nation and understanding their place within it. Touring was a "patriotic duty." 76 The demand to experience America through travel led to the creation of tourists' towns and attractions built around major highways and railways. Through tourism, Americans began to associate their democratic freedom with the ability to travel and experience all that their nation offered. 77 The nature of this new tourism was not as democratic as it appeared. It primarily was an experience created by private and public promoters for white, native-born, middle to upper middle class Americans to reaffirm American-ness through carefully produced landscapes. 78

Many Americans during this period chose to experience their own country rather than travelling abroad. Multiple factors led to this decision. Foreign travel required considerable financial resources and large amounts of time-luxuries that the average

\footnotetext{
75 Gabriel Kolko, The Triumph of Conservatism; A Re-Interpretation of American History, 190o-1916, (New York: Free Press of Glencoe, 1963), Alfred Chandler, The Visible Hand: The Managerial Revolution in American Business (Cambridge, Mass: Belknap Press, 1977), Alan Tractenberg and Eric Foner, The Incorporation of America: Culture and Society in the Gilded Age (New York: Hill and Wang, 1982), and William Leach, Land of Desire: Merchants, Power, and the Rise of a New American Culture (New York: Pantheon Books, 1993).

${ }^{76}$ Marquerite Shaffer, See America First: Tourism and National Identity, 1880-1940 (Washington, DC: Smithsonian Institution Press, 2001), 4.

77 Ibid., 6.

${ }^{78}$ Ibid.
} 
American did not have. Perhaps more important than finances, there was an overwhelming sense of American exceptionalism in the period. Americans wanted to see their own country. Why see the old world in Europe when you could see true roots of human civilization at home? Ancient remnants of native cultures, natural wonders, American battlefields, and sites where famous Americans lived and died were more sacred to a red-blooded American than anything available overseas.

American involvement in the Great War not only pushed America into the political world stage, but also increased the spread of Americans and their culture throughout the world. France particularly saw an influx of Americans following the Great War, specifically Paris. When American troops returned home from European battlefields the number of Americans permanently living in Paris stood at around 8,ooo. Through the early to mid-1920s, this swelled to between thirty and forty-thousand.79 Americans went to Paris for different reasons and were a far more varied group than the mythologized "lost generation" authors like Ernest Hemingway or F. Scott Fitzgerald. Some American intellectuals certainly did go to escape the choking hold of mindless American mass culture. A thriving African American community also embraced Paris for its social openness, creating a Harlem in Montmartre. ${ }^{80}$ Paris offered African Americans the ability to live as full citizens, something Jim Crow America did not. Others simply saw Paris as a place where their dollars bought more, alcohol flowed, and sex was readily available. By-and-large, Americans in Paris lived their lives as Americans. Although immersed in a different culture, they retained their own as well-

\footnotetext{
79 Brook Blower, Becoming Americans in Paris: Transatlantic Politics and Culture Between the World Wars (New York: Oxford University Press, 2011), 6.

80 William A. Shack, Harlem in Montmartre: A Paris Jazz Story Between the Great Wars (Berkeley: University of California Press, 2001).
} 
celebrating their own holidays, joining American clubs, frequenting American themed bars, and enrolling their kids in the organizations like the Boy Scouts. ${ }^{81}$

It is within this unique post-war environment that the American Battle

Monuments Commission initiated its commemoration efforts. Its possession of military remains gave the commission pieces of home that Americans abroad could travel to, fulfilling the same patriotic duty that domestic tourism presented at home. Leaders in the commission envisioned their sites in Europe as locations that Americans, and foreigners, alike would choose as the destination for travel plans. Attention to creating a tourist industry appeared in the initial testimony to establish the ABMC and came through in its early work.

A bill proposed to Congress as an alternative to what became the American Battle Monuments Commission encapsulates the tourism element of commemoration. Backed by members of the American Scenic and Historic Preservation Society from New York, the American Memorial Highway Commission proposed a WWI commemorative plan built around memorial highways in France and Belgium. ${ }^{82}$ This commission advocated working with the governments of France and Belgium to construct new, or use existing, highways in these nations that followed American military advances. These highways themselves would serve as memorials to American participation in the war, but also allow Americans to follow the advances of the American Expeditionary Forces from the comfort of an automobile. The commission also proposed to allow veterans groups to

\footnotetext{
81 Blower, Becoming Americans in Paris, 7.

82 The Memorial Highway Commission was proposed as H.R. 9634. Hearings Before the Committee on Foreign Affairs, House of Representatives, Sixty-Seventh Congress, Second and Third Sessions on H.R. 9634 and H.R. 10801 for The Creation of an American Battle Monuments Commission to Erect Suitable Memorials Commemorating the Services of the American Soldier in Europe, March 15-20, November 28, December 7-9, 1922 (Washington, D.C.: Government Printing Office, 1922).
} 
erect their own monuments along each road. The commission would do its part by placing interpretive markers at appropriate waysides. ${ }^{83}$ This bill failed, largely because of diplomatic concerns. Congress felt that America had no authority to dictate to France and Belgium where to build their own roads and how to use them. The upkeep of the memorial highways also seemed likely to generate significant financial burdens. Additionally, the likelihood of the French embracing major highways called "Lincoln Highway" or "Roosevelt Highway" through their country bordered on insanity. Representative Cockran from New York asked testifiers how Americans would feel if France or England came to the United States and demanded commemorative roads be built on their behalf? ${ }^{84}$ Another glaring absence in this bill was a plan for military cemeteries, which was featured prominently in the ABMC bill. Although the highway bill never passed, many of the ABMC's commemorative plans for WWI enticed pilgrims with highway tourism while en route to the cemeteries.

The officers of General Pershing's staff that pitched the idea of the ABMC to Congress felt that roads existed in France already sufficient for Americans to travel to battlefields. A colonel testified in 1922 that he assumed an "enormous number of Americans would visit the battle fields of France." ${ }_{5}$ French roads already permitted these Americans to travel from "Paris to the Rhine in a day and see all these things on the battle roads." 86 The ABMC envisioned travel to these battlefields functioning much like trails through National Parks in the United States. ${ }^{87}$ As stated earlier, the predicted increase in tourists correlated with expectations of visitations to remains. Cemeteries

\footnotetext{
83 Ibid., 7.

84 Ibid., 8.

85 Ibid., 18.

86 Ibid.

87 Ibid.
} 
were the top priority of the U.S. government, but it was forecast that the "people of America will not be satisfied merely with providing a God's acre for the bodies of the dead." 88 When Americans came, which they would, the ABMC felt they had to stand ready with an accurate history to share and travel suggestions. Finished American monuments in France would not be completed until the 1930s, but already Americans came to see graves and experience the battlefields where doughboys died. The only guidance these Americans had in most cases came from the guidebooks written from the perspective of the French and English. According to Pershing's men, "without accusing them [foreign guidebooks] of prejudice, they do not tell the correct details of what went on and what actually happened because of ignorance." 89 American passenger ship lines were similarly hiring French officers as tour guides for Americans seeking to visit the battlefields. These French guides often "regaled tourists with misinformation."9o Major Xenophon Price, who became the ABMC's first secretary, recommended that funding for accurate historical research to begin "as soon as possible" so that American participants of World War I, and their families, have an American narrative on hand for battlefield visits in their lifetime. 91

Much of the rush for an American perspective of the battlefields came from ongoing American tourist trips and from anticipation of large American tour groups

\footnotetext{
88 "American Cemeteries in Europe," Undated [Original Draft Version likely early 1920s], Box 5, Commission of Fine Arts, Entry 17, RG 66, NARA.

89 Hearings Before the Committee on Foreign Affairs, House of Representatives, Sixty-Seventh Congress, Second and Third Sessions on H.R. 9634 and H.R. 10801 for The Creation of an American Battle Monuments Commission to Erect Suitable Memorials Commemorating the Services of the American Soldier in Europe, March 15-20, November 28, December 7-9, 1922 (Washington, D.C.: Government Printing Office, 1922).

28.

90 Thomas North, One Soldier's Job (American Battle Monuments Commission: Unpublished, undated), I-20.

${ }^{91}$ Ibid., 30
} 
travelling to cemeteries in the future. In 1927, the American Legion planned a massive gathering in Paris, and in 1930, federally funded pilgrimages to cemeteries began for an estimated 17,00o Gold Star Mothers. ${ }^{92}$ The man tasked to write the ABMC's first guidebook was Dwight D. Eisenhower, a young major who had just missed overseas service during World War I. Eisenhower's job was to prepare a brief history of the A.E.F., provide information on American monuments, and to place detailed battlefield tours in the hands of American pilgrims. Eisenhower wrote in his preface that his work was "for the convenience of the tourists" and almost exclusively dealt with American forces (although he tactfully acknowledged the importance of allies).93 The guidebook offered not only a history, but also denoted a feeling of "pleasure touring," suggesting lodging, necessity of packing lunch, how to break up the day into manageable outings, travel times, and suggested priority for stops. 94 Eisenhower's guidebook was an instant success. The 20,000 copies printed sold out in less than a year-about three-percent of them purchased on American ships sailing to Europe. 95 Demand remained so high for the guidebook that an expanded and more widely circulated version was released several years after the original. In preparation of the updated guidebook, the ABMC's administrative secretary, Xenophon Price, tested the accuracy of information the ABMC

\footnotetext{
${ }^{2}$ John J. Pershing, "Our War Memorials in Europe, “ National Geographic Magazine 65, No. 1 (January 1934), 36. The article states that 6,700 Gold Star Mothers made the pilgrimage in the programs four years.

93 A Guide to the American Battle Fields in Europe (Washington, DC: Government Printing Office, 1927), $\mathrm{v}$.

94 Stephen Trout, On the Battlefield of Memory: The First World War and American Remembrance, 1919-1941 (Tuscaloosa: University of Alabama Press, 2010), xxi. And, A Guide to the American Battle Fields of Europe (1927 version), 131. The preface to Trout's book provides a superb overview of Eisenhower's service with the ABMC and a discussion of the implications that the guidebook had on American memory.

95 These statistics are taken from Lisa Budrea, Bodies of War: World War I and the Politics of Commemoration in America, 1919-1933 (New York: New York University Press, 2010), 275, endnote 6 for Chapter 17.
} 
provided tourists in 1927. Price personally followed the itineraries provided and was wholly disappointed with the product the ABMC offered tourists. He wrote to Pershing in 1928 that road directions needed to be completely re-written and that "errors were the rule rather than the exception.” Many of the mistakes he found inexcusable. Among the most glaring was the guidebook's marking of a German cemetery. Price travelled to the point on the road where the German cemetery should have been, but only saw a French "vineyard with clearly placed black posts." He was "highly suspicious" that the ABMC staffer who penned the itinerary lazily accepted grape vine stakes as headstones without close inspection. ${ }^{6}$ This instance shows the lack of attention initially shown to graves of former enemies.

${ }_{96}^{6}$ Price to Pershing, January 16, 1928, Box 7, Pershing Correspondence, RG 117, NARA. 


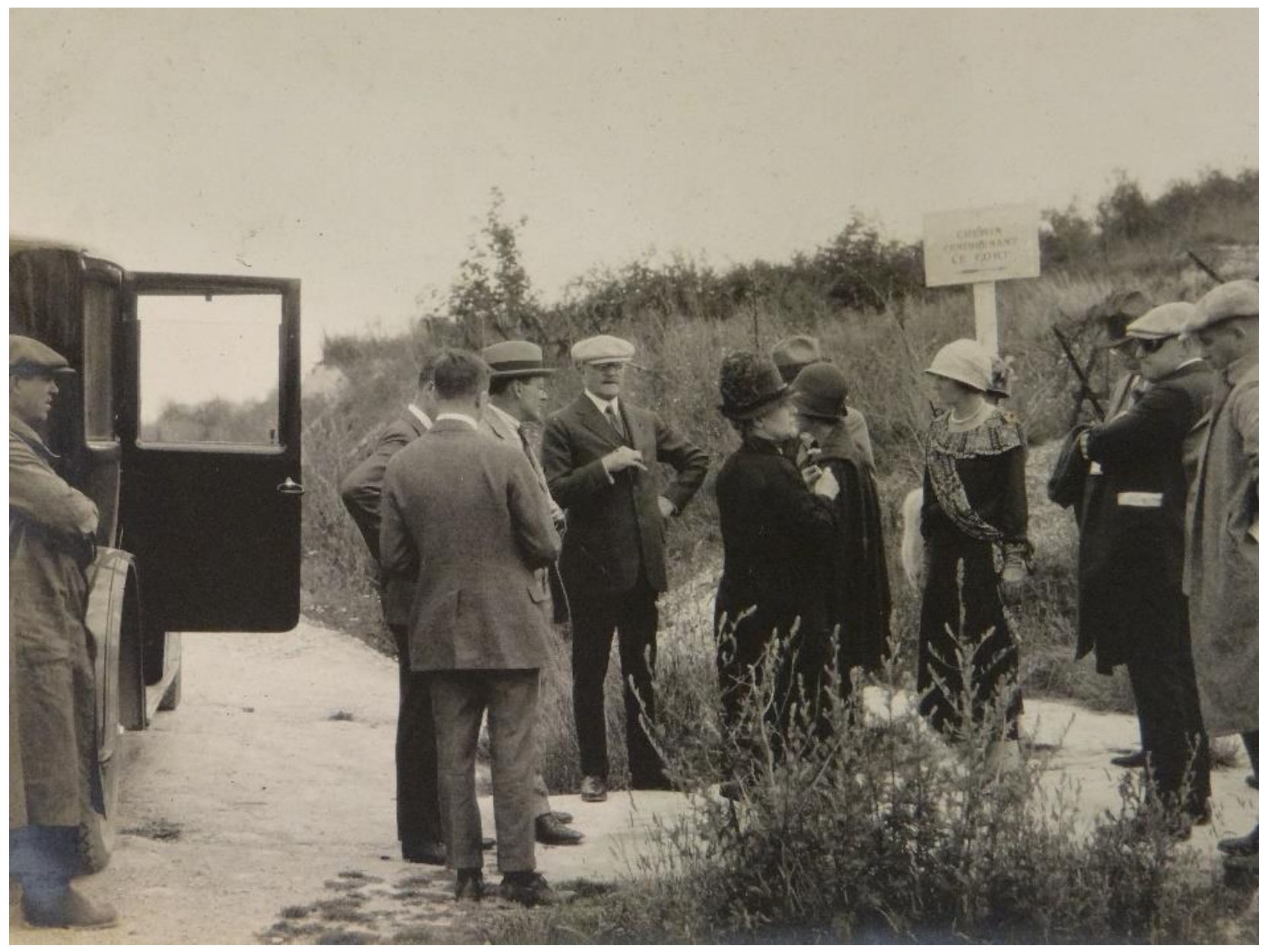

Photo 1.5: General Pershing giving ABMC Commissioners personal tour of Fort de la Pompelle in the early 1920s. Source: Thomas North Papers, U.S. Army Heritage and Education Center, Carlisle, PA.

Despite Price's criticisms of the early American guidebook, it gave American tourists an invaluable travel companion for World War I battlefield touring. It also stayed true to the goal of getting visitors to the American remains. Even though the cemeteries remained works in progress as tourists came to Europe, the guidebook reminded Americans of their patriotic duty. Everyone enjoyed leisurely tours, but "no American who travels to Europe should fail to visit” the sacred sites. If this message was not enough to incite guilt in Americans considering not going the cemeteries, the guidebook went further, assuring visitors that although spread out, the federal 
government "conveniently located the cemeteries near routes most tourists naturally follow."97 Suresnes proved to be a veritable tourist magnet. The Washington Star reported in 1927 that 26,000 Americans visited Suresnes as of September of that year. The paper concluded that the American military cemetery in Suresnes was an "attraction for American tourists which vies with the cabarets of Montmartre" and "shows how strong is the drawing power of this field of honor against the gay attractions of Paris.”98 ABMC sites further away from Paris apparently drew less visitors-surely because of difficulties securing travel and lodging. General Pershing likely felt little sympathy for American tourists complaining about ease of travel to more distant ABMC sites because cemetery pilgrimages were a patriotic duty. Apparently a duty which was not one to which sufficient Americans jumped to fulfill. In a 1934 National Geographic Magazine article attributed to General Pershing, he urged Americans to come see America's fallen and promised wary tourists of the "beautiful and comfortable" reception rooms built for the "convenience of visitors" that awaited them.99 Pershing's plea indicates that his ABMC's shrines to American remains were not drawing the visitors anticipated. One possible explanation for this is that the ABMC's commitment to diplomacy created commemoration much too traditional to capture the sensibility of a rapidly modernizing American society. ${ }^{100}$ The economic hardships suffered by Americans during the Great Depression also severely limited the ability for the average American to travel abroad.

\footnotetext{
${ }_{97}$ A Guide to the American Battle Fields in Europe (Washington, DC: Government Printing Office, 1927), 245.

98 “Tourists Visit Suresnes," The Washington Star, September 3, 1927, clipping from Box 6, Entry 17, Commission of Fine Arts, RG 66, NARA.

99 John J. Pershing, "Our War Memorials in Europe, "National Geographic Magazine 65, No. 1 (January 1934), 2. 100 Robin, Enclaves of Memory, 60.
} 
In addition to the attempts to bring American tourists abroad to visit American remains, the ABMC also sought to forge a specific memory of World War I by writing its official history. While a staff of Army officers worked to write the official guidebook and history for the ABMC throughout the 1920s, the ABMC also maintained a staff of historians to write official unit histories for each American combat division in World War I. The archival remnants of this project offers historians one of the richest collections of World War I memories in existence. The chief architect of the official histories was the ABMC's secretary Xenophon Price. Price was a scholarly man with intimate knowledge of all major A.E.F. military operations during World War I-he served as Pershing's chief mapmaker. The guidebook and unit histories were ABMC monuments in themselves, intended to stand the test of time and be the definitive sources for information in the future. Just as Price accepted no mistakes in the guidebook, and was angered when he found them, the unit histories needed the upmost accuracy.

Price and his team of historians acted as gatekeepers of memory when putting together the guidebook and unit histories. ${ }^{101}$ The ABMC's historical team used after action reports and other primary source documents to piece together as much of the complicated history of American combat operations as possible. The massive scale of American offensives in the Great War, and the near constant shifting of ground required the ABMC historians to go beyond the official reports. Correspondence with officers present during specific engagements became a necessity. As fragile as memories of chaotic fighting were, Price's team had to rely on veterans memories to verify their

${ }^{101}$ For the theoretical framework of this argument see Richard Hulver, "Ezra Carman: The Gatekeeper of Memory at Antietam National Battlefield (Morgantown, WV: WVU Master's Thesis, 2011). 
interpretations and fill in analytical gaps. When Price corresponded with A.E.F. veterans to receive their recollections, he took steps to guide their memories towards the heroic and controlled narrative of the Great War that the ABMC desired-the same narrative visible on its commemorative landscape in Europe. This was a narrative of order, control, and unified sacrifice. Price's historical team initiated a correspondence with veterans in a regimented fashion. They sent American veterans a standardized form letter that asked basic tactical questions. If the ABMC historian had already written a narrative of the event and only wanted confirmation, the completed narrative would be included along with a map of the terrain for the veteran to mark his movements on the field. A letter to Lieutenant Colonel Frank Burnett, an American officer who was present for the first German raid on American troops in the Great War, gives a good example of the ABMC's tactics. In this letter, Price included an essay written by ABMC historians entitled "The First Raid on American Troops" for the officer to read and comment upon. ${ }^{102}$ Burnett was "personally engaged in the encounter" and the ABMC wanted him to give "any comments or criticisms" the he cared to share about their essay. ${ }^{103}$ The ABMC also wanted him to make any appropriate marks on their "photostatic copy of the trench system present during the raid."104 Burnett was assured by Price that "no comment or criticism" would be "unimportant or not of interest in [their] research."105

Price's team corresponded with veterans with total respect, but took effort to keep his memory in the ABMC's realm. By including a written narrative of the

\footnotetext{
${ }^{102}$ X.H. Price to Frank Burnett, November 5, 1927, Box 184, Officer Correspondence, RG 117, NARA. 103 Ibid.

104 Ibid.

105 Ibid.
} 
engagement, the historians at the $\mathrm{ABMC}$ gave the veteran something that would interact with his memories and keep them on track. The inclusion of a map of Burnett's trench system helped bind his memory to one small section of one battlefield. Upon receiving the ABMC's inquiry Burnett immediately doubted his memory of events nearly a decade past and forwarded the ABMC inquiry to comrades for their memories and recollections so he could test the accuracy of his own memories. In the end those individuals that Burnett shared his memories with agreed that "in short, your memory serves you correctly..."106 This affirmation allowed Burnett to confidently make very slight alterations to specifics of company designations made in the ABMC's report, but ultimately confirm to Price that he "found no other errors in the summary." 107 This exchange shows a very efficient process adopted by the ABMC history section, but also gives some indication that the $\mathrm{ABMC}$ was pushing their own interpretation on veterans they spoke with.

Sometimes the ABMC's inquiries brought forth memories that did not remain within the framework that the government wanted. Other officers, involved in the same raid that Burnett was, chose to go into much more detail with their responses to Price. William McLaughlin, another participant of the raid, provided an incredibly detailed account that highlighted the inherent confusion of trench warfare and the lack of glory in battle. McLaughlin began his account of the German raid by describing their initial shelling of the American position: "the first shell came in. . .it was followed by two more in quick succession and these two were followed by three more, and then-CHAOS."108 The concussion of these exploding shells knocked McLaughlin to the ground and he

\footnotetext{
106 Kingman to Burnett, November 20, 1927, Box 184, Officer Correspondence, RG 117, NARA. 107 Burnett to Price, December 6, 1927, Box 184, Officer Correspondence, RG 117, NARA. 108 McLaughlin to Price, December 5, 1927, Officer Correspondence, RG 117, NARA.
} 
admitted to experiencing "violent spells of nausea."109 Once he was able to regain his composure he remembered becoming alert and "squirming out from under Corporal Gresham who had been killed by being shot between the eyes. ..," after this he took a drink from his canteen "which seemed to be the most important thing in the world at the time."110 He then began moving through the trench system to assess the situation, walking over American casualties. His memory then focused vividly on the violent scene in the trench. He recollected a stairway "red with blood, and American and German equipment scattered all over the place." ${ }^{111}$ One of the American rifles was broken at the stock and partially covered "with blood and hair."112

This account recreated the chaos of war effectively, and it appeared to be extremely accurate. McLaughlin still had his field message book from the night in his possession, and demonstrated in his narrative that he had communicated with other Americans involved in the raid to verify his memories. He also submitted a photograph of the American soldiers that the German's captured in the raid. This version of warfare was not totally represented in the ABMC's cemeteries-they acted more as shrines to peace than representations of actual warfare. While historically important, McLaughlin's account had little value to the ABMC's official history. They were courteous of his response nonetheless, stating that "your extremely interesting comments will make a valuable addition to the files [emphasis added] of the Commission and will be of material assistance in making final decisions on this matter."113 McLaughlin's message was both useful and powerful, but it strayed from the

\footnotetext{
109 Ibid.

${ }^{110}$ Ibid.

${ }^{111}$ Ibid.

112 Ibid.

113Price to McLaughlin, December 28, 1927, Box 184, Officer Correspondence, RG 117, NARA.
} 
established discourse of the dead. American tourists would not find McLaughin's version of the war in the ABMC sites, they found a much more sterilized and usable memory.

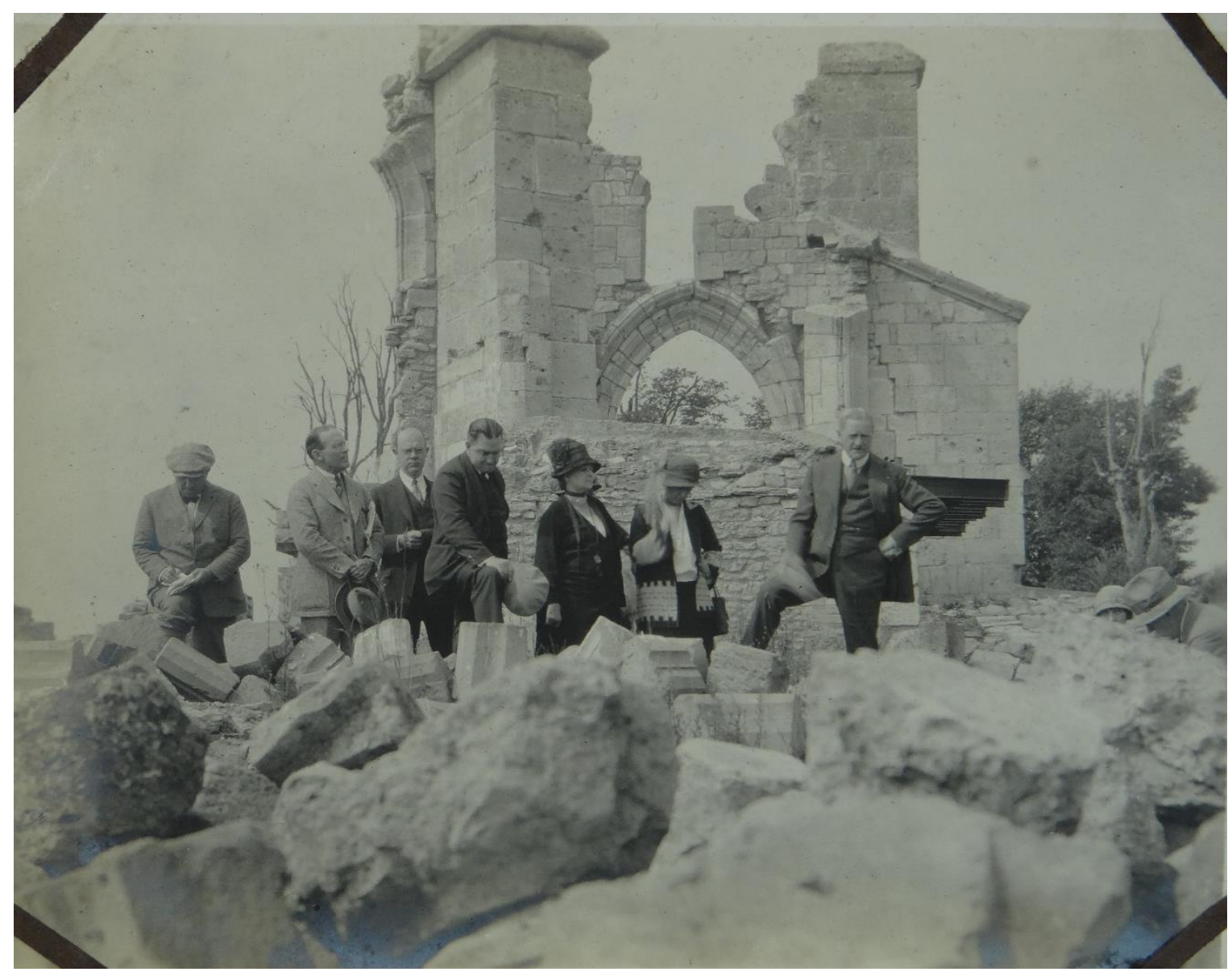

Photo 1.6: General Pershing giving ABMC Commissioners personal tour of ruins at Monfaucon in the early 1920s. Source: Thomas North Papers, U.S. Army Heritage and Education Center, Carlisle, PA.

\section{Conclusion}

All combatants of the Great War possessed large numbers of military dead at the end of hostilities and needed to establish disposition plans. The United States stood out 
among combatants as a unique case for the commemoration of its dead.114 When American families said their goodbyes to service members going overseas they expected to see them again someday, hopefully alive, but possibly as corpses. The wholesale return of American soldier dead never happened, however. Not wanting American sacrifice for Europe to be forgotten, American military and political leaders formulated ways to mark American exploits on European soil. Most of these plans involved the addition of military remains. Only with American bodies could a powerful vocalization of American sacrifice and plans for future relations be articulated. As American commemorative plans evolved, the modern American government asserted itself as the official architect of American memory. Demands of U.S. citizens forced the government to offer all grieving families a choice of final disposition of their dead. After final decisions, the American government maintained possession of approximately 31,000 bodies. These remains became a precious commodity distributed in ways deemed appropriate for commemorating the American war effort in its entirety. Cemeteries became indistinguishable from other monuments. The cemeteries and the bodies within served as the lure to attract visitors and stand as sites of diplomatic memory for the future.

The burial of American military remains abroad is not a story capable of telling with only Americans. American cemeteries and memorials on French soil required French assistance. The French played a major role in the establishment of these cemeteries. French promises to care for and respect American remains in their soil for the remainder of time, coupled with real displays of French care for American graves,

\footnotetext{
114 Jay Winter oversimplifies U.S. sentiments regarding its war dead in Sites of Memory, Sites of Mourning: The Great War in European Cultural History (Cambridge: Cambridge University Press, 1995), 27.
} 
moved many Americans to leave their bodies overseas. French reverence for American dead similarly gave American decision makers a platform to articulate diplomatic aspirations. Many Americans viewed French promises as hollow, however.

Organizations formed in the United States in response to widespread beliefs that France only wanted American dead for their own benefit. Dead American soldiers might bring tourists' money and ensure that if attacked again, the American military would not wait until the final hour to come to France's aid. American distrust of France seems somewhat displaced in this period. It was the American government that pushed for control of remains more so than the French. It was also the American commemorative machine that placed its WWI bodies at the center of tourism plans.

Once the permanency of American military cemeteries was established and a discourse of American sacrifice present in France, politicians in both France and the United States engaged the discourse to confront one another as relations changed throughout the twentieth century. The mid 1920s through the start of WWII saw some of the highest tensions between the two nations. During this period, both French and American politicians frequently navigated the discourse of American sacrifice created by American war remains to strengthen their arguments against one another and to demonstrate friendship. Foreign policy objectives and relationships between nations are not static and move through good times and bad. Corpses do not have the luxury of self-mobility, however. They remain interred whatever the current circumstance. The interwar years in France placed American war dead in one of the most chaotic and unfriendly periods in the Franco-American relationship. Wilson's death brought pause to the liberal world order he dreamed of achieving. Conservatives led the United States for most of the 1920s. Under this leadership, the memory of American dead abroad 
came to serve more as an aggressive means to combat the rising tide of socialist political thought on the European continent. 


\section{Politicizing God's Acres in 1920s France}

And wheresoe'er these white-cross shadows fall, There are our "Fields of Honor"; for when'er

Earth drew our dying soldiers to herself

Soldiers enlisted in Earth's cause of right She gave the ground they touched to their own land:

White acres added to America ${ }^{1}$

Once the final disposition of American military remains took place, and the erection of the official U.S. WWI commemorative program began, these sacred sites underwent further politicization. This chapter demonstrates the early political uses of American World War I dead in France through the volatile 1920s. It assesses the uses of American memory as a diplomatic tool by analyzing the utility of memory during times of anti-American protest. Looking at the way American memory was used to by leaders to address protest surrounding war debt and communist protest in France through the 1920 ultimately shows that the liberal memory that Wilson crafted for American dead evolved into a more proactive weapon for conservatives to wield in the $1920 \mathrm{~s}$.

Throughout the 1920 s various iterations of political protest thrived in France, most of them directed against the United States. When war reparation policies of the United States and Great Britain seemingly benefitted Germany more so than France, right-wing veterans groups in France mobilized in protest of the United States. These French veteran's groups occupied their sacred spaces in Paris in an effort to inspire American veterans to appeal to the leaders to change policies. The extreme right fascists groups in France engaged in less restrained protest and blatantly attacked Americans in Paris. Some leaders in the United States fabricated stories of French desecration of

${ }^{1}$ John Finley, "The White Acres in France," Current Opinion, Vol. LXXI, No. 3, (September 1921), 373. 
American graves in order to illicit more aggressive Congressional policies towards France.

In the first month of the Great War's final year, America's Consul in Paris, Tracy Hollingsworth Lay, telegraphed Washington his assessment of France's political and economic situation. Lay's analysis focused primarily on the different French political factions and the future stability of the nation. Nearing his conclusion, he aptly summarized the way America needed to approach France diplomatically moving forward. "Their country is the strategic heart of the allied cause and must be nurtured with corresponding tenderness and care," Lay said. Furthermore, the turmoil of war and recent Russian political upheaval created momentous changes in all segments of French society. Lay warned Washington that it would be unwise "should the allies fail to realize that they must in subtle ways so shape their acts as to win their cause before the unknown offspring of the spirit now germinating in the debris, rises forth to proclaim its birth" in France. ${ }^{2}$ Consul Lay saw the inevitability of significant changes in Europe following the Great War. French support for America was a prerequisite if Washington wished to involve itself in European affairs after aiding in victory. France was the gateway to continental Europe and there was little chance, from an American perspective, of sustaining a positive Franco-American diplomatic relationship if communist revolutionaries took control of Paris. Lay's plan to "shape their [French] acts through subtle ways" sums up America's diplomatic strategy towards France throughout the twentieth century. 3

\footnotetext{
${ }^{2}$ Consulate Tracy Lay, "Politico-Economic Tendencies in France," January 12, 1918, Box 1241, Department of State, Central Decimal File 10-29, RG 59, NARA. 3 Ibid.
} 
The transfer of America's memory of its sacrifice for Europe through military remains would fulfill Lay's hopes for subtle diplomacy in France. ${ }^{4}$ Memory proved itself a cultural product capable of transfer much less obtrusive to foreigners than other forms of culture such as consumerism or popular culture. While a concerted effort came from Washington to create a specific memory of American sacrifice on sites of memory abroad, there was also an organic draw to these cemeteries. American political and military leaders did not force French women to visit its military cemeteries and decorate graves. Nor were French spectators made to attend American memorial ceremonies. French came to these sites voluntarily to show thanks for American support in the war. It was reported on Memorial Day in 1921 that the "French took part in every ceremony, and in places where there was only a single grave." 5 Often American delegations could only send one representative to isolated burial sites, but in these instances, the French seemingly always supplied a crowd of mourners. In one French village a local priest led "the school children to an isolated American grave" that they had guarded and cared for as if it belonged to them."6 This kind of account replayed frequently throughout the twentieth century in France-and still does to this day. The natural draw of these cemeteries made them suitable locations for restrained diplomacy. American military

\footnotetext{
4 Most diplomatic historians focus on the transfer of American popular and consumer culture as the primary means for the United States to subtly enter European politics. This type of transfer often proven not so subtle, however, and sparked resentment from foreign countries. Memory proved a much more subtle cultural means to establish an American presence on foreign soil. To see examples of cultural transfer studies see Reinhold Wagnleitner, Coca-colonization and the Cold War the Cultural Mission of the United States in Austria After the Second World War (Chapel Hill: University of North Carolina Press, 1994), Richard H Pells, Not like Us : How Europeans Have Loved, Hated, and Transformed American Culture Since World War II (New York, NY: Basic Books, 1997), Victoria De Grazia, Irresistible Empire : America's Advance Through Twentieth-century Europe (Cambridge, Mass.; London: Belknap Press of Harvard Univ. Press, 2006), Richard Kuisel, Seducing the French: The Dilemma of Americanization (Berkeley: University of California Press, 1993).

5 "France Decorates our Heroes' Graves," The New York Times, May 31, 1921, in Proquest Historical Newspapers.

6 "France Decorates our Heroes' Graves," The New York Times, May 31, 1921, in Proquest Historical Newspapers.
} 
remains tempered French perceptions of Uncle Sam by utilizing the positive memories most French assigned to the American soldiers who sacrificed to save their nation. The continued presence of American military dead in French soil demanded treatment with the utmost tenderness and care. American military dead represented a fighting force when alive, but transformed into more peaceful representations in death. The aggressive memory of a fighting force was resurrected at times in the 1920 .

A Memorial Day ceremony on the grounds of Suresnes in 1921 showed the positive bond that American military dead forged in the early interwar period. It also confirmed understanding from an American diplomat that remains fulfilled the kind of bond that consular Lay espoused. American Ambassador Hugh Wallace, and France's heralded Marshal Pétain, concentrated most of their commemorative remarks on where American military dead should rest. The reason for this focus was the ongoing finalization of American repatriation decisions. This was Wallace's final Memorial Day speech abroad before Ohio politician Myron T. Herrick took over as his replacement. Wallace held little back in his address to an international audience. He lamented on the "mistake" America had made in allowing families to pull soldier dead from their "sleep in the soil of France."7 He understood a mother's desire to want her son back, however, feared that most chose repatriation out of grief without fully considering the larger implications of overseas burial. Could the mothers see France's willingness to perpetually keep American graves green through their love, they no doubt would leave them resting in France's "fields of honor."8 Marshal Pétain reiterated Wallace’s sentiments, expressing his “infinite regret” in seeing "American graves depart one by

\footnotetext{
7 “France decorates our Heroes' Graves," The New York Times, May 31, 1921, in ProQuest Historical Newspapers.

8 Ibid.
} 
one from the soil of France."9 It was the American remains, according to Pétain, that created the "basis of an eternal friendship." 10 Without graves to perpetually visit, the French could only guard fleeting memories of the common hope and fighting spirit they shared with America during the Great War. ${ }^{11}$ Physical corpses offered a reminder more tangible than lingering memories. The rhetoric of these two influential diplomatic figures bordered on the overdramatic. The cemetery was not emptying before their eyes and not all American bodies in the ground at Suresnes had a trans-Atlantic ticket tacked to their headstone. Still, the prospect of a future without American dead in French soil was undesirable to these influential speakers. On this Memorial Day, mourning took place not just for the dead, but for the loss of the dead. The words of Ambassador Wallace and Marshal Pétain showed that American corpses in France offered both nations a feeling of security. The presence of the dead indicated to Pétain an American investment in France's future. To Wallace, France's desire to entomb Americans verified an acceptance of America's presence in Europe.

French news indicates that many French attended American memorial ceremonies, but did not fully understand these aggressive foreign commemorative efforts. France itself was a culture that highly valued its past and dead, evident from its own post-war commemorative practices and in the overwhelming acceptance of American war dead. ${ }^{12}$ French news reporters covering the Suresnes ceremony, nonetheless, related the foreignness of America's Memorial Day practices. Conservative newspaper La Gaulois reported that Americans had the "highest degree of a cult of

\footnotetext{
9 Ibid.

10 Ibid.

${ }^{11}$ Ibid.

${ }_{12}$ For an explanation of French burial practices see Jay Winter, Sites of Memory, Sites of Mourning (Cambridge: Cambridge University Press, 1995), 22-28.
} 
remembrance," devoting an entire day to "the worship of their dead soldiers" each year. ${ }^{13}$ This practice was not new, Americans had worshiped military dead for half a century. It was perfectly reasonable for Americans to fervently participate in such a somber day in their own country. Yet, strangely, in the twentieth century this cultish ceremony appeared to be "celebrated with as deep a fervor" in France as in America. ${ }^{14}$ Americans had gone from a tourist presence to major cultural force in France in less than a decade. American devotion to its soldier dead seemed infectious to the French. Alongside the entire "American colony in Paris" that traveled to Suresnes to mourn each year stood countless French.15 French and American soldiers served in the honor guard, French and American flags adorned the American graves, and bands played both national anthems. It was clear why Americans traveled to these ceremonies, but more difficult to understand French participation. French reporters discerned that something about these ceremonies seemed to help French participants place themselves in the modern world. The resting places of American soldiers acted as spaces to espouse both Americanism and Frenchness. The two powerful democracies found common ground in the memory of American dead despite political or social differences.

Weekly reports from America's Paris embassy reveal that American holidays aside from Memorial Day broke into French culture also. It was reported that the first Fourth of July after the war was "celebrated in France with a brilliancy which is said had never before marked a foreign anniversary commemorated on French soil.” 16

\footnotetext{
${ }_{13}$ Memorial Day At Suresnes American Cemetery Speech of Marshal Pétain and Mr. Hugh C. Wallace, La Gaulois, May 31. 1921, in digital archives of Bibliothèque Nationale de France.

14 Ibid.

15 Ibid.

16 "Weekly Report to Secretary of State from Paris Embassy," July 5, 1919, Box 1241, Department of State, Central Decimal File 10-29, RG 59, NARA.
} 
Ceremonies in honor of America's birthday took place throughout Paris including the review of France-American troops by President Poincare on the Place De la Concorde. Several celebrations concluded with "pilgrimages to the tombs of Americans."17 American embassy officials saw French celebrating another nation's birthday as a "remarkable demonstration of French official and popular friendship for America."18 Although massive in itself, the French July $4^{\text {th }}$ celebration served mainly as a "prelude to the French celebration of victory on July $14^{\text {th }}$ to which 4 million francs had been appropriated for festivities." 19

Interacting with World War I memory in France was not wholly an American experience. A receptive audience of foreigners engaged with American sites of memory, and Americans engaged frequently with French sites of memory. Reciprocation was a crucial element of the commemorative machine. Americans also participated in French commemoration and venerated French soldier dead. American tourists, veterans, and government officials frequently laid wreaths at the Arc de Triomphe in respect of France's unknown poilu. American ambassadors participated in dedication ceremonies of French war monuments. France's Trench of Bayonets memorial to the $3^{\text {rd }}$ Company, $137^{\text {th }}$ French Infantry Regiment, a group of men collectively buried alive within an imploded trench during the Battle of Verdun, showed the functionality of memory in diplomatic relations. Private American banker, George F. Rand donated to the French government 500,000 francs to erect a fitting monument after he visited the French mass grave and saw that relic hunters had already begun looting the site. ${ }^{20}$ To Rand,

\footnotetext{
17 Ibid.

18 Ibid.

19 Weekly Report to Secretary of State from Paris Embassy,” July 5, 1919, Box 1241, Department of State, Central Decimal File 10-29, RG 59, NARA.

${ }^{20}$ Winter, Sites of Memory, 99.
} 
and the French, the remains at this site captured the essence of France's war experience. At the crucial hour of combat, France was not broken. The French soldiers killed in this trench stood forever ready to jump into battle. The bayonets of their still shouldered rifles sprung from the soil as proof. Although a French monument, American financial support made the site somewhat Franco-American. When the large, yet minimalist, monument protecting the burial trench underwent dedication in December 1920 many American dignitaries participated.

Ambassador Wallace served as America's primary representative during the day. Wallace's dedicatory address acknowledged that Verdun was France's own battlefield, that she "faced the Hun alone," and that the civilization saving victory could be "shared by none." ${ }^{21}$ Wallace continued his praise of France, yet humbly placed a token of America on the field in thanks - a memorial stone from America symbolizing "gratitude and eternal national friendship." ${ }^{22}$ This was the type of subtle gesture to nurture relations Consul Lay hinted to in the years prior. America could assert itself on the French memorial landscape in a respectful and non-threatening manner. French reporters indicated an understanding of the newness of dual Franco-American participation in each other's' memorial practices. ${ }^{23}$ The diplomacy of memory offered nations a medium to show powerful connections without the dominant undertones found in economic or military relations. The memory of war dead found at the Trench of Bayonets functioned as one type of diplomatic glue between the two nations, just as

\footnotetext{
${ }^{21}$ Hugh Wallace, "Speech given at the dedication of the Bayonet French Monument," December 8, 1920, from online edition of The Formal Address, (1922), http://www.oldandsold.com/articles28/publicspeaking-11.shtml( accessed February 12, 2014).

${ }^{22}$ Ibid.

23 Memorial Day At Suresnes American Cemetery Speech of Marshal Pétain and Mr. Hugh C. Wallace, $L a$ Gaulois, May 31. 1921, in digital archives of Bibliothèque Nationale de France.
} 
American dead had in Suresnes. As tensions between the United States and France increased over the following years sites of memory remained places to comment on mutual threats to their security.

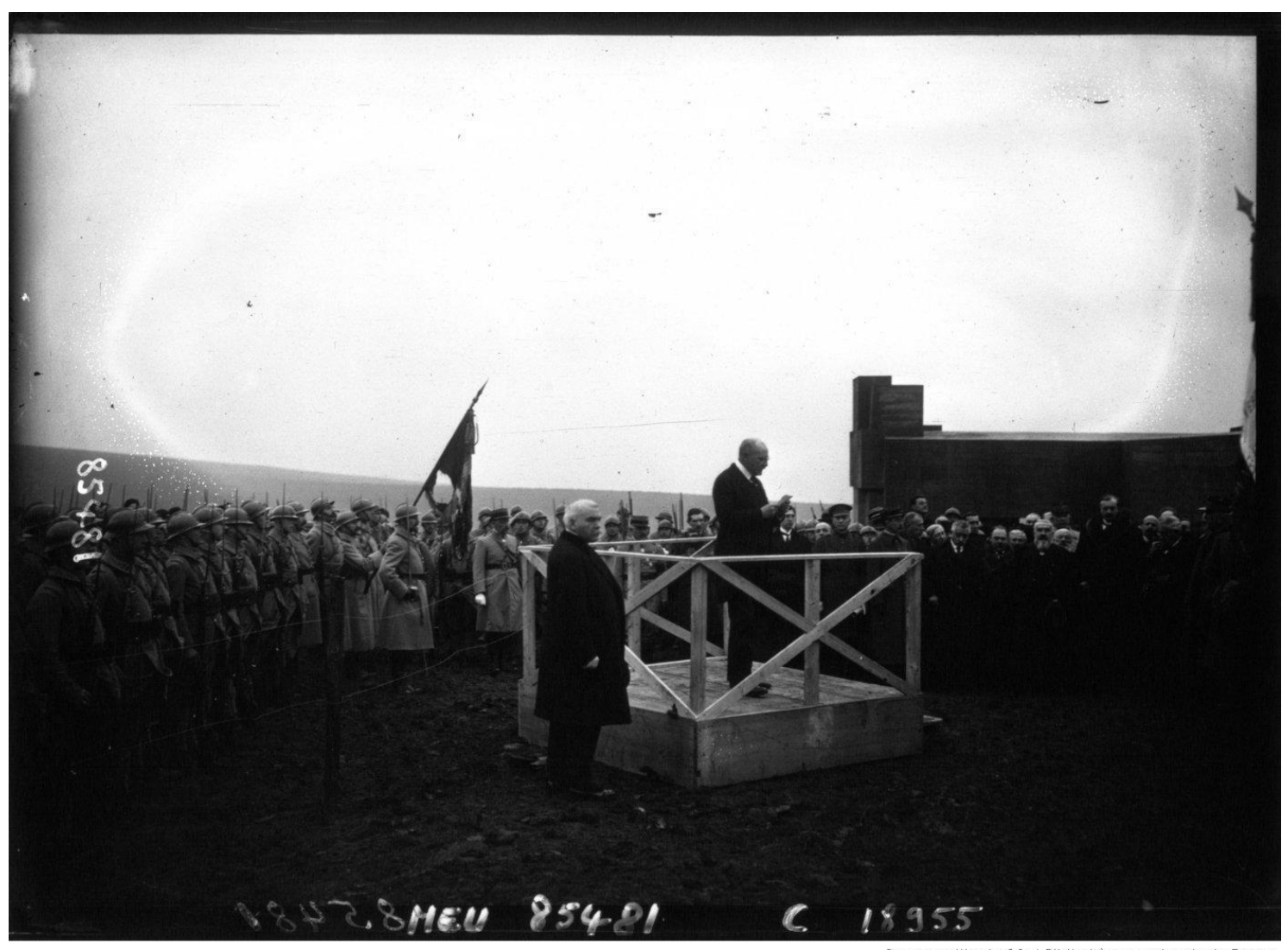

Photo 2.1: Ambassador Hugh Wallace delivering address at Trench of Bayonets, 1920. Source: Bibliothèque nationale de France, département Estampes et photographie, online archives.

Rising Tensions: War Debt and American Enslavers

American leaders, like Wilson, frequently cited the friendliness of French soil as justification for leaving American soldier dead abroad and maintaining positive relations. This idealistic comprehension of soil's friendliness in 1919 did not come with any guarantee. Despite critical French aid in the America's Revolution and American 
contributions to the World Wars, cultural misunderstanding and political disagreement dominated Franco-American relations. France's top diplomat in the United States during World War I, André Tardieu, dispelled the myth of American friendship in a 1927 publication. Tardieu wrote of the Franco-American relationship as one with "short periods of political cooperation-less than ten years in all, out of one hundred and forty-[that] were the result not of sentiment, but of interest; and that as soon as interest lapsed, sentiment did not suffice to maintain cooperation.”24 Both countries turned to one another for support only when their livelihood depended on it. Between brief interludes of friendship, a distrust festered between the nations that frequently erupted into heightened periods of anti-Americanism in France brought about by "exceptional" events. 25 It is during the exceptional periods of heightened FrancoAmerican tensions that the soft power of memory became more of a necessity in diplomatic relations.

Public memories of American military remains offered French and American leaders opportunities to rhetorically frame commitments to one another following World War I. Yet, the memory of remains proved somewhat apolitical in the years immediately succeeding the Great War. The rhetoric of the dead found an audience, but the relationship between France and the United States was stable enough that the memory of American dead served more as an articulation of foreign policy hopes and less as a weapon. Growing French anti-Americanism in the mid to late 1920s regarding war debt and treatment of left-wing ideology made U.S. leaders forcefully wield the

\footnotetext{
${ }^{24}$ Roger, The American Enemy, 263. Quoting Tardieu, France and America: Some Experiences in Cooperation (Boston: Houghton Mifflin, 1927), 294.

25 Ibid., 268.
} 
memory of U.S. sacrifice for France. A battle for a future of Old World or New World domination had begun. Because Americans represented the New World belligerent in the battle, all things American took on symbolic meaning, including the dead. Both American and French war dead turned into ways to engage with the other's culture. Perceived insults to the living was acceptable, because the living maintained an ability to defend themselves and right the wrong. The dead, however, had no capacity to defend themselves from desecration.

The interwar period in France was a period of political transformation and extremes. The initial problem for France was how to shift from mourning back to the realm of living. The millions of dead buried in their soil, broken families, along with countless veterans shattered both physically and mentally served as constant reminders of war losses. ${ }^{26}$ Alleviation of these burdens of grief required reconstruction of the economy and infrastructure. A large portion of working-class Parisians struggled to make ends meet, despite being on the winning side of the war. ${ }^{27}$ The United States stood in the best position to assist in France's recovery. Among the Allied powers, it emerged from the war almost totally unscathed. Consequently, the loans it distributed to its partners made it the main international creditor. American consular Tracy Lay predicted before the Great War ended that the "great weapon of the present war is economic power" and "the United States sits in control over the destinies of her Allies." ${ }^{28}$ Europeans had little power to control the outcome of their own war by time Americans entered in 1918. The United States could likely force any of its Allies "into

\footnotetext{
${ }^{26}$ Roxanne Panchasi, Future Tense: The Culture of Anticipation in France Between the World Wars (Ithaca: Cornell University Press, 2009), 5.

${ }_{27}$ Blower, Becoming American, 59

28 Tracy Lay, "French Socialism and the War," February 12, 1918, Box 1241, Department of State, Central Decimal File 10-29,, RG 59, NARA.
} 
immediate capitulation through an embargo which the President is empowered to proclaim."29 Although this notion was an undiplomatic way to conceptualize America's relationship with France, it was a realistic assessment. This unbalanced power relationship stood as a main point of contention between France and the United States following the war. Parisians struggling to live on incomes significantly less than pre-war came to resent spend-thrift Americans. A Parisian woman wrote the American ambassador the she felt "irritated and impatient" as well as "vanquished" when she saw everywhere "Americans filling restaurants and the hotels. .."invading all France, you who are so rich and prosperous and smiling." 30

By 1929 all Parisians realized that their lives forevermore would include Americans. Americans frolicked all around them, its soldiers came and went, and its dead remained in their soil. France's future, no doubt, included Americans. A thriving community of Americans resided in Paris, and visited France immediately following WWI. Paris was the tourist destination for Americans wishing to see Europe. It was a place to escape restrictive social policies in America, spend money freely, and consume high culture. The influx of Americans helped put money into the French economy and rebuild following the war. French businesses in areas frequented by Americans catered to the tourists embracing the use of English to lure them to their doors. ${ }^{3^{1}}$ Yet, this also created resentment among many French. The value of the American dollar in comparison to the franc was significantly higher, giving Americans access to excesses in France at the expense of the locals. By the mid-1920s, anti-Americanism sentiments

\footnotetext{
29 Tracy Lay, "French Socialism and the War," February 12, 1918, Box 1241, Department of State, Central Decimal File 10-29, RG 59, NARA.

3o Blower, Becoming American, 70. Quoted as "Herrick to Frank Kellogg, July 161926 in Myron Herrick Papers, folder 64.

${ }^{31}$ Blower, Becoming Americans in Paris, 45.
} 
reached a point so high in Paris that Americans needed to "sink into a state of denial" to not see it. $3^{2}$ Many of the Americans spending time in Paris acted as ungracious guests. American arrogance, drunkenness, recklessness, and ignorance proved themselves as consistent stereotypes. From the perspective of many Americans, being French meant ungraciousness, greed, deceit, and weakness. 33 Warrington Dawson, a writer and special assistant at the American Embassy in Paris wrote to the State Department in Washington that the rise of anti-Americanism was not as prevalent as indicated in the press. He reported that French newspapers were entirely biased, representing only the radicals and whatever party happened to be in power. Dawson assured Washington that the anti-Americanism was primarily a façade "since the mass of the French people have the most affectionate feeling towards America, and perfectly realize all that they owe to the United States in general and to President Wilson in particular.” 34

The attitude of many Americans was that France owed them a debt of gratitude for sacrificing American blood on their behalf. This sentiment was seen in the previous chapter from correspondence of the Bring Home Our Soldier Dead League. Americans who lost family members on the Western Front felt that France had no right to dictate any terms to Americans regarding its own war dead. The debt of gratitude that France owed was not as pressing of a debt as the monetary one, however. Had America shown its physical investment in France's future by joining the League of Nations and becoming part of France's security, French sentiments towards U.S. interwar policies

\footnotetext{
32 Ibid.

33 Harvey Levenstein, We'll Always Have Paris: American Tourists in France since 1930 (Chicago: University of Chicago Press, 2004), ix.

34 Warrington Dawson, "Dispatch Number 6978," January 19, 1919, Box 1241, Department of State, Central Decimal File 10-29, RG 59, NARA. In this dispatch Dawson quotes a conversation he had with an unnamed French Foreign Deputy.
} 
might have been less severe. To get Europe on the path to economic recovery American investors realized that Germany needed assistance, not harsh punishment. If Germany failed to readjust its economy in the post-war and defaulted on its reparation obligations, America and the rest of Western Europe could fall to communist revolutionaries.35 Avoiding economic panic in Europe required America to enact a series of unpopular debt repayment plans. The 1924 Dawes Plan became the most wellknown American repayment plan. The goal of this policy was to "revitalize the German economy with loans while withholding capital from allies to force them into a payment schedule for their war debts.” ${ }^{6}$ In practical terms, the plan only required Germany to pay France seventeen billion gold marks, yet required France to pay the United States twenty-seven billion.37 Many French felt that while Americans "fought the war with us; they make the peace against us." ${ }^{8} 8$ As the plan went into effect, it faced major protest from the French. July 1926 brought some of the most violent anti-American displays in France during the interwar period. This was due in part to the exchange rate reaching its highest point since the war. 39

One of the most politically vocal groups in France were working class laborers, among which many were veterans. 40 This group had sacrificed most for France's victory in the Great War. They carried with them the baggage of war and felt unjustly victimized by America's policy. These soldier laborers, with exposure to violence, called

\footnotetext{
35 Bentley Mott, Myron Herrick: Friend of France, An Autobiographical Biography (New York: Doubleday, Doran \& Company, 1929), 264.

${ }^{36}$ Blower, Becoming Americans 56.

37 "French War Veterans Plan Protest of Debt," New York Times, July 3, 1926, in Proquest Historical Newspapers.

${ }^{38}$ Blower, Becoming Americans 56. Quoted as "What the French Think of Us, $A M$, December 1925, 47986.

39 Blower, Becoming Americans, 56.

40 Ibid., 59.
} 
upon the "fourteen national bodies" of veterans and war victims to collectively demonstrate against the United States in Paris on July 4, 1926.41 This event on America's birthday was a stark contrast to festive July $4^{\text {th }}$ celebrations the year after the war. The French government stepped in to save the American holiday and postponed the veterans' movement for two weeks. When the protest took place, reports estimated that twenty-thousand French veterans mobilized. ${ }^{2}$ Once mobilized, the veterans placed a wreath on their tomb of the Unknown and then collectively gathered at the statue of George Washington in silence while holding memorial flags from veterans groups all over France.43 The protest did not take on a violent tone, yet they hoped the strong showing might be enough to move the American people, particularly, their American "comrades at arms" to stop Washington from "enslaving” France with impossible debt obligations. 44 This movement did not include a pilgrimage to American graves at Suresnes. It did, however, begin before French war remains and finish before the form of George Washington-the European symbol of the American Revolution. The obvious goal of French veterans was to improve Franco-American relations through shared memories of American and French soldiers who sacrificed similarly in combat.

Anti-American sentiments increased in France in the days following the veterans' protest. On the night of July 23, over one hundred right-wing French "Fascisti" descended a tourist company's convoy of six open topped charabancs filled with

41 "French War Veterans Plan Protest of Debt," New York Times, July 3, 1926, in Proquest Historical Newspapers.

42 "Paris Parade of the Mutilated on July Fourth Planned as Protest on War Debt Settlement," The New York Times, June 20, 1926, in Proquest Historical Newspapers.

43 "French War Veterans Plan Protest of Debt," New York Times, July 3, 1926, in Proquest Historical Newspapers.

44 Ibid. 
American, German, and English tourists paying to see "Paris by Night." 45 The mob attacked the cars near the Paris Opera forcefully removing passengers to specifically "berate the Americans." 46 The mob rapidly grew and Parisian police arrived. Unable to disperse the mob to get the cars moving again, they advised the Americans to "disappear" on foot. 47 The fascists remained well into the night "shouting against Americans and hurling epithets at passers-by whom they took for citizens of the United States." 48 A few fistfights broke out, but for the most part the American tourists remained reserved in the face of a large hostile crowd. An Italian fascist newspaper reported that the likely motive for their French counterparts was retaliation for American Senator William Borah's reaction to the veterans' march in the days before. Senator Borah dismissed the veterans protest against the United States as misplaced and blamed the French government's "domestic policy and imperialistic schemes" as the reason for economic hardship.49 Italian fascists felt that the French veterans' "austere and touching plea" deserved more than the "cynical and arid words" of a United States Senator. .0 $^{\circ}$ The United States was attempting to enslave the whole of European continent by "manipulating loans" from behind the safe "teller's window of banks." 51 Italians believed that American tourists thus deserved what the fascisti delivered. The reports of anti-Americanism in Paris alarmed President Calvin Coolidge enough to elicit an official statement to American tourists in the New York Times.

\footnotetext{
45 Edwin L. James, "Parisians Insult American Tourists, Single Out Our Citizens for Catcalls in Streets, Several Fights Resulting," The New York Times, July 24, 1926, in Proquest Historical Newspapers. 46 Ibid.

47 Ibid.

$4^{8}$ Ibid.

49 Ibid.

50 Ibid.

${ }^{51}$ Ibid.
} 
Coolidge wanted the French to know that he did not consider American tourists "blameless" in the recent incidents. Coolidge felt that there were two types of American tourists spending time in Paris, "bumptious uneducated" and "appreciative." ${ }^{2}$ The former failed to recognize that the French had gone through "a very dark and trying period and were even now facing serious difficulties" with mourning and economic hardship.53 The bumptious Americans often showed the French disrespect that justifiably caused resentment. Coolidge urged all American tourists to show greater reserve when interacting with the French. He also hoped that the French did not consider the few bad Americans as a representation of the "real America" because he did not take the manifestations of a few hostile French as a reflection of the French as a whole. 54

The 1926 protests did not specifically involve American military remains as means to prove French discontent with American policies. American politicians did turn to American military remains as weapons to respond to French protest, however. In the months following the veterans' and fascists' demonstrations against America, Arkansas Senator Thaddeus Caraway made incriminating comments against the French in the New York Times. Caraway was an ardent Wilson supporter, who happened to be travelling through Europe at the time of the July protests. Caraway reported to Americans that French protestors crossed sacred lines in their manifestations and attacked American dead. He explained that French hatred towards their former allies had reached despicable levels. According to Caraway, French protestors had left the

52 "Coolidge Cautions American Tourists," The New York Times, July 28, 1926, in Proquest Historical Newspapers.

53 Ibid.

54 Ibid. 
streets of Paris, entered into American cemeteries, and vandalized the tombstones of American soldiers with phrases like "To Hell With America." 55 The only respectable solution Caraway formulated as a remedy was extreme. He pushed Congress for the immediate passage of legislation funding the repatriation of the 30,000 American dead that the French had taken to insult on a daily basis. ${ }^{6}$ The dead once served as symbols of friendship, but now they represented a soured relationship. Caraway saw removal of American bodies as the ultimate punishment against France.

Senator Caraway's claims stirred emotions in Americans and the French. The problem with his assertion was its total lack of evidence. The day after his allegations against the French, the U.S. War Department publicly rebutted the Senator. The War Department assured Americans that the officers assigned to each American cemetery in France never reported any form of desecration to American graves.57 Additional public counters to Caraway came in the following days, the most powerful of them from Pennsylvania Senator, and ABMC commissioner, David Reed. Reed heard of Caraway's remarks while vacationing in Paris and reported to the American public that he had just toured the American cemeteries and witnessed no vandalism whatsoever. Reed suspected that in order to make a powerful political statement, Caraway opted to stretch the truth and cite a comment Reed himself had made the previous year about "irresponsible" French children disfiguring a private monument erected by the U.S. Twenty-Seventh Division. $5^{8}$ Reed went on to assure the American public that despite

\footnotetext{
55 "Says French Insult Graves of Our Dead," New York Times, September 15, 1926, in Proquest Historical Newspapers.

${ }^{6}$ Ibid.

57 "Denies Grave Desecration,” New York Times, September 16, 1926, in Proquest Historical Newspapers. 58 "Senator Reed Denies Grave Desecration," New York Times, September 20, 1926, in Proquest Historical Newspapers.
} 
recent anti-American protest, the French showed "nothing but respect and sympathy" for the dead Americans.59 Reed's overall assessment of the French was that, as a whole, they "make respect for their dead a veritable cult" and that he witnessed firsthand the shocked reaction the French had to Caraway's claims. ${ }^{60}$

Reed's assertion of French shock toward Caraway's attack against them was correct. The French government denied any such vandalism and demanded that Caraway offer proof before leveling such insults. ${ }^{61}$ Furthermore, a French native travelling on Caraway's boat during his return voyage wrote on op-ed for the New York Times discrediting the Senator. The Frenchman explained that, through multiple conversations with Caraway, he learned that the Senator spoke and read no French and exhibited total confusion toward French culture. ${ }^{62}$ As a French native, he felt betrayed by Caraway's remarks and explained to Americans that no matter how some French may feel toward living Americans; no matter how irritated they may get with American tourists, the French people respected and venerated the American soldiers who died in battle just as they do their own dead. ${ }^{63}$ Caraway's assertions undoubtedly represented assumption, not fact, in the Frenchman's assessment.

Caraway's commentary about the French desecration of American graves, and the heated reactions, reveals much about the sacredness of the memory surrounding American war remains and their sacrifice. Woodrow Wilson chose to frame his argument for collective security with his own memory of American war dead, and

\footnotetext{
59 Ibid.

6o Ibid.

61 "Paris Press Indignant at Caraway Charges," New York Times, September 18, 1926, in Proquest Historical Newspapers.

${ }^{62}$ Simone France, “Caraway Views Disputed," New York Times, September 20, 1926, in Proquest Historical Newspapers. 63 Ibid.
} 
Caraway similarly used their memory to make a stand against French war debt protest. Caraway publicly acknowledged afterwards that his claims of French desecration came from no personal observation. ${ }^{64}$ His choice to package anti-French sentiment in a baseless claim about disrespect for American soldier dead demonstrated how powerful the symbolism of American war dead was at the time. Caraway likely understood the deep convictions Americans held for their war dead and felt that a French breach of trust might push Congress to be tougher on the French regarding financial policies. Conversely, the overwhelming French feeling of insult towards Caraway's comments showed the high level of esteem and sacredness they felt towards American war dead. Clearly, French respect for American sacrifice defined by war remains was not challengeable, even during a time of great protest against the United States. This episode demonstrated how both France and the United States used the American dead to define their culture to the other. The United States viewed itself as a proud nation who sacrificed for another and thus demanded respect. Similarly, France portrayed itself as an honorable and grateful nation that understood the importance of sacred boundaries and self-control.

A 1929 article in The National Geographic Magazine written by France's former ambassador to the United States, J.J. Jusserand, addressed the French protest towards America regarding war debts that had garnered headlines for several years. Jusserand showed assurance to Americans that France remembered American sacrifice by quoting famed statesman Aristide Briand's address to the French Chamber over debt issues. Briand told the Chamber that it was their duty to "cry out to that great friendly people

64 “Caraway Says Reed Made Tomb Charges," New York Times, September 19, 1926, in Proquest Historical Newspapers. 
beyond the sea who played their part in an especially dolorous hours that France does not forget.” Furthermore, Briand promised Americans that "in spite of untoward remarks about the debts, France's gratitude remains intact, deep-seated in her heart."65

\section{Using Memory to Address the Red Menace}

The anti-American protest in the previous section involved French veterans and right-wing fascists groups. These groups certainly posed a threat to American dominance in Europe and the possible safety of American tourists. Still, the biggest perceived threat to Americans during the interwar years was communism. Fascist governments in Italy, and later Germany, eventually seemed too dictatorial and cultish to most Americans, yet their effectiveness garnered some respect through their early stages. Corporatist policies and decisive leadership reserved the bad fortunes of both Italy and Germany. During the Great Depression, American intellectuals looked fondly on Mussolini and Hitler for rejuvenating their nations while others faltered. Mussolini proved particularly appealing to Americans in the "roaring twenties." The theatrics of the "strutting dictator" whetted the appetite of Americans engrossed by mass spectacle.66 Many in America saw Mussolini's "determined action" as affirmation of the appeal that "traditional American common sense and human drive" had abroad. Mussolini was, to Americans, a hero because of his willingness to initiate the same "progress and efficiency" that made the United States great. ${ }^{67}$

\footnotetext{
65 J.J. Jusserand, "Armistice Day and the American Battle Fields," The National Geographic Magazine, Vol. LVI, No. 5, November 1929.

66 Costigliola, Awkward Dominion, 95.

${ }^{67}$ Ibid., 96.
} 
Towards the end of World War I, the American embassy in Paris took note of a "spirit of change in France" in which the "old molds are to be broken." 68 This break would likely come in the form of "rejuvenation, evolution, or revolution." 69 There was hope among both French and American diplomats to avoid "serious misunderstandings between the two" because they might drive a stake between the nations. ${ }^{70}$ Both nations needed to take proactive measures to diminish the voice of left-wing supporters and "limit discontent against America" to the small pro-Bolshevik supporters who inspired it. ${ }^{71}$ Swift action might assure the continuance of the "real friendliness and community of interests which exist in our hearts." 72 The American who primarily shouldered the burden of keeping Franco-American relations intact during the interwar years was Ambassador Myron T. Herrick. Herrick's time as American Ambassador to France included frequent engagement with the memory of both French and American war dead. He often sounded the bugle for American military dead to rise and teach their lessons to the living.

Myron Herrick was a Republican politician from Cleveland, Ohio. Before entering public life, he was a successful businessman. He served as Ohio's governor from 1904-1906. His next major public service role came in 1912 when President Taft appointed him to serve as America's Ambassador to France. Herrick resigned from this post immediately following Woodrow Wilson's assumption of the presidency, however,

\footnotetext{
68 Tracy Lay, "Politico-Economic Tendencies in France," January 12, 1918, 12. Box 1241, Department of State, Central Decimal File 10-29,, RG 59, NARA. 
he was not replaced until 1914. Herrick served in France during the initial stages of the Great War and became a symbol of hope to the French that America supported their cause. Herrick unsuccessfully ran for Ohio's senate seat after returning to the United States because of the Republican Party's inability to supplant Wilson's democrats. President Harding sent Herrick back to France as Ambassador in 1921, were he served with distinction until his death in Paris in 1929. Herrick was one of the most beloved American ambassadors to France, despite his service during the height of French antiAmericanism, being one of the few U.S. ambassadors to have a Parisian street named in his honor.

Herrick arrived to France on Bastille Day in 1921 to an inordinate amount of fanfare for a diplomat. The French remembered his vocal support for their fight in 1914 . Witnesses reported that it was as if "the seven terrible years that had intervened since his departure had not blurred their memory."73 Many in France saw in Herrick "a friend of France .... who will be the well-informed witness of our fears and our desires."74 Much of Herrick's popularity likely came from his uncanny ability to navigate the memories of the Great War and pull on French heartstrings through American military sacrifice. Herrick thrived in the role of ambassador. Despite his old age, he kept up a vigorous social schedule. His assistant reported that American holidays brought Herrick the heaviest workload. With the Great War not so distant a memory, each holiday required attention to the dead. "Memorial Day, the Fourth of July, Thanksgiving Day, etc., etc., involved not only a banquet and speech, but visits to our cemeteries, to the Unknown Soldier's grave [and] to the Tomb of Lafayette, according to

73 Mott, Friend of France, 259.

74 Ibid., 259. Quoting Le Intransigeant. 
Herrick's close associates."75 Herrick chose not to send a proxy to these events and yearly engaged in them "cheerfully, with unfeigned pleasure." ${ }^{6}$ His assistant reported that it was not only American holidays that demanded Herrick's attention. "He [Herrick] was asked almost every day of the year to preside at a banquet ... dedicate a monument ... or be present at some reunion; and always with the expectation that he would make a few remarks." 77 It was often during these pilgrimages to the dead that Herrick chose to make some of his most powerful speeches on the state of FrancoAmerican relations. Herrick seemingly understood that engaging with the sacred memory of the dead made for a more powerful message.

Herrick served as Ambassador to France for nearly eight years. Providing a complete account of all his commemorations to American dead would be both difficult and repetitive. His autobiography does, however, explicitly show the strategic uses Herrick saw in American war remains. As America's top diplomat in France during the peak of anti-American sentiments, Herrick needed to use every weapon in his arsenal. The war debt protest in France greatly disturbed Herrick. He felt that France was "bleeding and impoverished" and that it deserved America's aid and sympathy. ${ }^{78}$ At the same time, he was revolted anytime the French accused America of "forgetting the war and why it entered."79 Claims that America had "deserted an old friend and turned its sympathies towards her enemy" were intolerable. ${ }^{80}$ Herrick used a 1923 speaking engagement at the dedication of a monument to American soldiers killed in Champagne

75 Ibid., 294.

76 Ibid.

77 Ibid., 293.

78 Ibid., 270.

79 Ibid.

80 Ibid. 
to combat French assertions and awaken Americans of their present role in world economics. Herrick asked his living audience if they, the ones who profited from the sacrifice of the dead, could stand on their battlefield and assure them that they "faithfully executed the trust" which the dead placed in them? ${ }^{81}$ He felt that this was impossible. Americans died fighting Germany because it threatened the "commercial and physical welfare" of America, France, England, Belgium, and Italy. Their sacrifice was to stabilize the economic system. The current debates over debt repayment created a "European mess," which if assessed using "common sense and business judgment," almost replicated the atmosphere that brought Americans to the battlefields in 1917.82 Herrick was unanimously speaking for American dead, using them to show the French that America had not forgotten and was committed to fixing the problem. Furthermore, the dead in French soil showed Americans that they retained a stake in the European situation. Unwillingness of American politicians to rise above partisan politics and address the international economy not only "sullied the memory of American dead," but made their sacrifice in vain. ${ }^{83} \mathrm{He}$ articulated similar sentiments by co-opting the voices of American dead in speeches leading up to 1926.

Issues regarding war debts held the attention of American and French leaders, however, communism directed the memory of American dead during the interwar period. A major catalyst for this came from increasing international protest among communist, socialist, and anarchist groups throughout Europe over the American judicial system's treatment of Italian immigrants Ferdinando Sacco and Bartolomeo Vanzetti. Sacco and Vanzetti both openly claimed ties to the international anarchist

\footnotetext{
${ }^{81}$ Ibid., 271.

82 Ibid.

83 Ibid., 272.
} 
movement and were arrested in 1920 for association with a murder-robbery incident at a shoe factory in Braintree, Massachusetts. The evidence against the two men was nowhere near as strong as the Red Scare hysteria sweeping through the United States. The Massachusetts judge who tried the two immigrants openly showed bias toward them during trial and sentenced them to death. Supporters of Sacco and Vanzetti in France cited a statement by the Massachusetts' judge to prove American injustice. The judge reasoned that "although not having participated materially, in the crime which they are charged, [they] are morally guilty on account of their ideas." 84 A lengthy appeals process followed the first trial and the two men remained imprisoned for years awaiting their fate. It was not until August 1927 that their executions by electric chair finally took place. Left-wing groups throughout the world sympathized with Sacco and Vanzetti. Violent protest against the injustice shown by America sporadically erupted world-wide throughout the ordeal. The most violent protests came the year of their conviction in 1921 and their execution in 1927. Myron Herrick's ambassadorship in Paris, the location of some of the most heated Sacco-Vanzetti protest, forced him to confront the issue directly.

Herrick first became entangled in the Sacco-Vanzetti case when left-wing activists in Paris attempted to assassinate him in his Paris office in October $1921 .{ }^{85}$ Infuriated that Sacco and Vanzetti faced imminent death unless the Massachusetts Supreme Court granted an appeal, radicals organized demonstrations throughout the world to force presidential interference in the trial. Ambassador Herrick started

\footnotetext{
84 "Buisson to Herrick," May 22, 1926, Box 3674, Department of State, Central Decimal Files 10-29, SaccoVanzetti Files, RG 59, NARA.

85 "Cablegram from American Consulate in France to Secretary of State," October 27, 1921, 311.6521SaI, Box 3674, Department of State, Central Decimal 1910-20,RG 59, NARA.
} 
receiving mail protesting the Boston judge's verdict in the fall of 1921, but nothing to merit fear for his life. On the morning of October 19, 1921, a package from a well-known perfumery arrived at Herrick's Paris office. A busy day of meetings followed by an afternoon reception for General Pershing at the Hotel de Ville prevented Herrick from opening the package at work. Instead, his staff took Herrick's mail to his private residence. Herrick's valet noticed the package of perfume as Herrick arrived home for the evening and opened it up due to a recent request from his boss to purchase a similar item. When Herrick's valet opened the box, the pin of a grenade was pulled. It detonated and blew shrapnel into the valet's leg and severely damaged several rooms. It failed to kill its mark, however. American reporters immediately picked up the story and categorized the assassination attempt as a communist plot. A message from the leader of the French Communists in L'Humanité the following day calling for continued "protestation more and more vigorous on behalf of the two un-fortunates who have only a few days more to live if the proletariats of all the world do not come to their rescue" caused many to blame communists for the murder attempt. ${ }^{86}$ Herrick himself never explicitly targeted the communists as the guilty party, yet his public contestation of Bolshevism grew throughout his ambassadorship. Ultimately, the first Sacco-Vanzetti verdict underwent a lengthy appeals process that culminated with the Massachusetts Supreme Court's decision to uphold the original sentence. The rejected appeal unleashed a second surge of anti-Americanism abroad years later.

\footnotetext{
86 Edwin James, “Bomb for Herrick Wounds His Valet," The New York Times, October 20, 1921, in Proquest Historical Newspapers.
} 
When the Italian anarchists' appeal was denied, the New York Times reported that Herrick received multiple death threats from anarchists. ${ }^{87}$ Protest letters from various French organizations also inundated Herrick. Ferdinand Buisson, president of France's Human Rights League appealed to Herrick to speak with his government to overturn the injustice. Buisson believed that after five years in prison Sacco and Vanzetti had suffered enough, their case was forgotten, and such a delayed execution unnecessarily cruel. ${ }^{88}$ Herrick defended his government to Buisson, highlighting the Frenchman's ignorance of the American judicial system and appeals process. Sacco and Vanzetti faced a fair trial and had the best legal team available to them. ${ }^{89}$ As for the delay in their execution, Herrick attributed this to decisions made by the defense team and Sacco-Vanzetti supporters. Herrick also reminded Buisson that he was perhaps the wrong man to contact because Sacco-Vanzetti supporters had attempted to kill him not so long ago. 90 The French government and Myron Herrick took steps to prevent more violence against American diplomats in Paris once the inevitability of Sacco and Vanzetti's death became clear in 1926. Herrick put all embassy staff on alert and warned them not to leave embassy grounds in times of visible communist protest. $9^{1}$ Parisian police also sent extra men to guard the embassy throughout the hostile period. Herrick followed his common practice of using America military remains to take his strongest stance against communism. Since 1926, French and Americans had

\footnotetext{
87 "Coolidge Cautions American Tourists," The New York Times, July 28, 1926, in Proquest Historical Newspapers.

88 "Buisson to Herrick," May 22, 1926, Box 3674, Department of State, Central Decimal Files 10-29, Sacco-Vanzetti Files, RG 59, NARA.

89 "Herrick to Buisson," May 26, 1926, Box 3674, Department of State, Central Decimal Files 10-29, Sacco-Vanzetti Files, RG 59, NARA.

9o Ibid.

${ }_{91}$ Myron Herrick, "Telegram to the Secretary of State," June 1926, Box 3674, Department of State, Central Decimal Files 10-29, Sacco-Vanzetti Files, RG 59, NARA.
} 
engaged in "periods of petulant nagging and quarreling."92 In May of 1927, "providence imposed" and the charismatic Charles Lindbergh dropped from the sky.93 Within hours after Lindbergh's groundbreaking trans-Atlantic landing in Paris, French sentiments towards America improved dramatically. For the first time in quite a while, it seemed that more American flags adorned French buildings than Sacco-Vanzetti posters. Herrick capitalized on the spontaneous calming of the storm and delivered a frontal assault on communism during his Memorial Day address at the Suresnes American Cemetery on May 30, 1927, just over a month after the finalization of Sacco and Vanzetti's fate.94 Herrick's address repackaged and redefined the sacrifice of American soldiers in World War I. The same soldiers that Wilson once claimed had sacrificed all for collective security, now represented sacrifice against the "sinister" Bolshevik movement coming from Russia. 95 Herrick perceived these radicals as France's primary social disturbance.

Herrick's 1927 address aimed to undermine the rhetoric of Russian communist leaders and take legitimacy away from their revolution. "Either we believe in orderly society-or don't, "Herrick told his audience. ${ }^{96}$ Every nation of the world was at the point of choosing between "order and anarchy, between honesty and thievery, and between virtue and crime."97 The United States and France chose order, honesty, and virtue. The American graves at Suresnes, coupled with a large French audience, proved

\footnotetext{
92 Mott, Friend of France, 352.

93 Ibid.

94 Lindbergh was not present because he participated in Memorial Day ceremonies in England the same day.

95 "Urges the World to Fight Against Red 'Peril'," New York Times, May 31, 1927, in Proquest Historical Newspapers.

96 "Urges the World to Fight Against Red 'Peril'," New York Times, May 31, 1927, in Proquest Historical Newspapers.

97 Ibid.
} 
to Herrick that both nations had shared past committed to stopping "tyranny."98 Both France and the U.S. demonstrated in World War I that the spirit of their "revolutions" started in 1776 and 1789 still lived.99 Both nations still remained willing to fight for democracy and freedom, but many citizens in both nations failed to recognize the imminent threat of the communist disease within their borders. Russia's communist revolution promised a government in the "name of the people," but Herrick saw the revolution as a ruse. Instead of providing freedom of choice and happiness, it created the most oppressive government in human history. ${ }^{100}$ It was Herrick's hope that both France and the United States might see in American graves the sanctity of their revolutions, and dismiss the Russian revolutionary fervor as a disease that threatened a peaceful future. American military dead buried in France represented a direct link to American colonial militia from the eighteenth century. The doughboys died to stop tyranny just as colonists did, and communism represented the newest iteration of tyranny. ${ }^{101}$ The surge of radical left-wing protest against the United States signified that the communist cancer was eroding Franco-American democracy. Herrick summoned the memory of the American ghosts of Suresnes just as Wilson had in 1919. However, he now saw in them not a fight for collective security, but one to suppress cancerous revolution. In this instance, Herrick hoped that the French people might find themselves on the side of the Americans once more, and join in an international fight against the Red Menace.

\footnotetext{
$9^{8}$ Ibid.

99 Ibid.

100 Ibid.

${ }^{101}$ Ibid.
} 


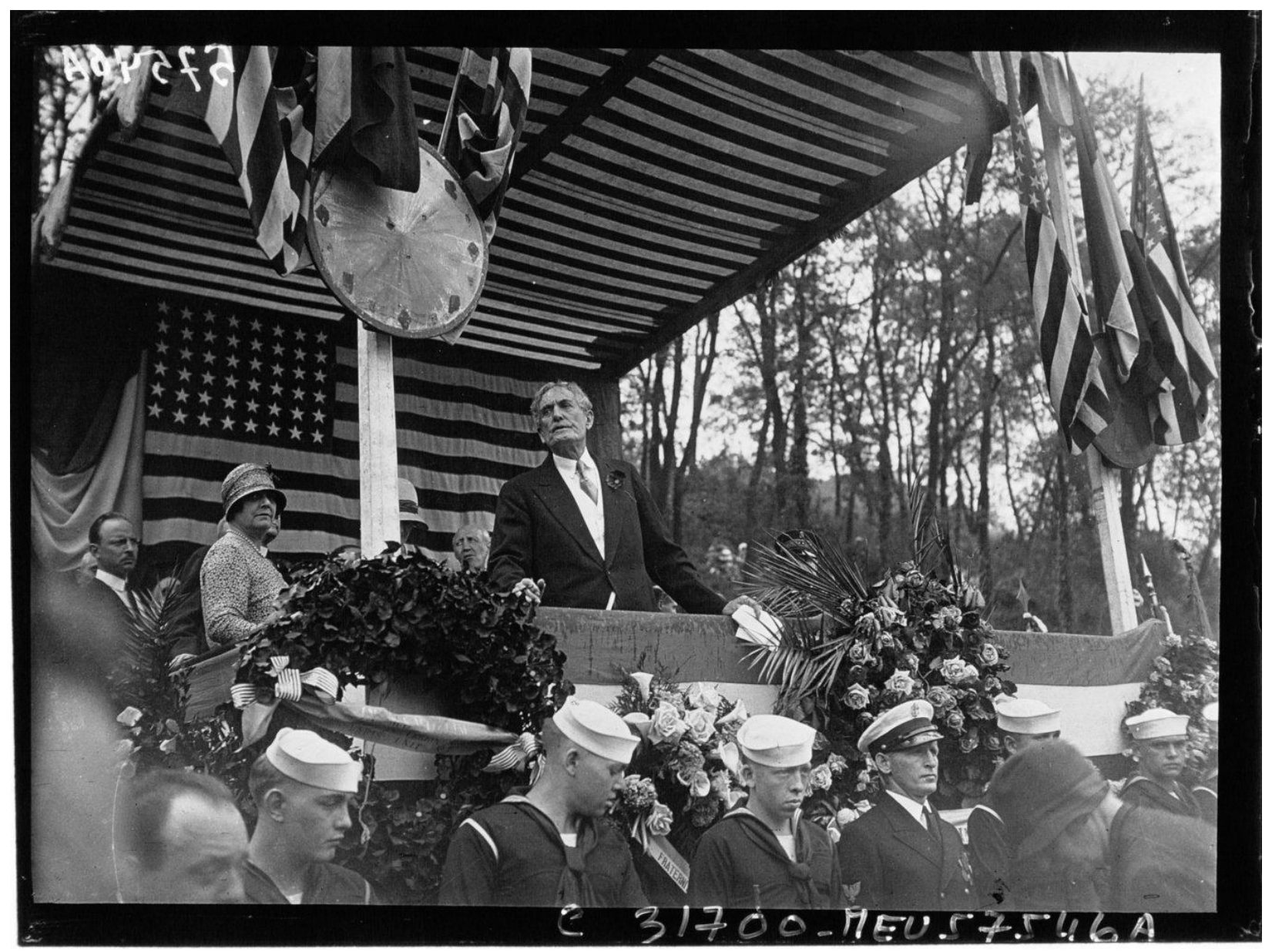

Photo 2.2: Ambassador Myron Herrick, Suresnes Memorial Day Address, May 1928. Source: Bibliothèque nationale de France, département Estampes et photographie, online archives.

In Herrick's biography, written by his close friend Colonel T. Bentley Mott, and based partially on Herrick's own dictations to Mott, he explained his motivations for the speech. Mott used Herrick's correspondence with Warren Harding to show Herrick's belief that the Republican Party needed to resist giving the official recognition of the new Soviet Union that other allied countries recently had, namely Great Britain and France. Herrick sympathized with the Russian citizens, despite thinking that their revolution was flawed, and understood the strong economic ties America had with 
Russia. Nevertheless, he felt his country needed to take the ideological high ground. ${ }^{102}$ Herrick's decision to attack communist Russia in his 1927 Memorial Day address was a calculated decision according to Mott. Ambassador Herrick witnessed an alarming number of poor working-class Frenchmen turning to communism and desired to do his part to reverse this without risking involvement in the French political system. The solution to Herrick's dilemma was to use the memory of American war dead through his station as ambassador. Herrick determined that if he chose a "strictly American occasion, held in an American cemetery" to address his compatriots and the French attendees through a message invoking memories of "his own dead," he could maximize the power of his speech. ${ }^{103}$

The calculated risk worked. Herrick's message created waves in France, the press carried excerpts of the speech for days, the French government was pleased about the American message, and Great Britain severed relations with the Soviets the following day. ${ }^{104}$ In no way did he succeed at keeping Franco-American relations at their postLindbergh high, however. While the most visible press coverage of Herrick's speech revealed positive reception, it initiated strong reactions by leftist groups. In the days following Herrick's speech, socialist French paper L'Humanité showed a strong dislike of Herrick. The paper reported that "the enemies of communism badly chose their champions. Myron Herrick, whose stupidity is a laughing stock in diplomatic circles, represents the United States in France, especially in the French cemetery where he is

\footnotetext{
102 T. Bentley Mott, Myron Herrick, Friend of France: An Autobiographical Biography (Garden City, New York: Doubleday, Droran \& Company, 1929), 322-330. It should be noted that T. Bentley Mott became the director of the ABMC's European office during WWII. 103 Ibid. 104 Ibid.
} 
accustomed to being photographed smiling."105 Herrick's enemies understood his tendency to use the dead to achieve a political goal, and particularly resented seeing him do so in sacred sites around France.

The electric chair ended the lives of Sacco and Vanzetti after midnight on August 23, 1927. The proactive security measures taken by Herrick and the Parisian police proved necessary. Leftists groups in Paris initiated the biggest riots of all major cities world-wide. They marched en-masse to sites well associated with Americans, including the embassy where police waited to push them back. The right-wing led police met the rioters with armed guards and large scale violence took place throughout the night. Police arrested hundreds of rioters and assaulted many more. ${ }^{106}$ At dawn the next morning, parts of Paris looked like a war zone with over 10,000,000 francs worth of damage recorded and over two hundred police officers recovering from wounds received during the rioting. ${ }^{107}$ The Sacco-Vanzetti riots of 1927 were widespread throughout Paris, but leftist groups traditionally faced difficulty trying to protest. Throughout the 1920s, the French government attempted to maintain order by limiting left-wing political manifestations. All processions within Paris except holiday celebrations, national holidays, or commemorations needed prior approval from the government. ${ }^{108}$ This policy specifically targeted leftist groups. The few permits granted went to rightwing organizations because these often included veterans' groups or other patriotic leagues. ${ }^{109}$ Leftist groups usually circumvented the non-protesting policies by staging

\footnotetext{
105 “Our Enemies,” L'Humanité, June1, 1927, in digital archives of Bibliothèque Nationale de France. ${ }_{106}$ Blower, Becoming American, 95.

107 Ibid. And, "French Sympathy Swings to Legion," New York Times, August 26, 1927, in Proquest Historical Newspapers. 108 Blower, Becoming American, 112. 109 Ibid.
} 
their movements in the suburbs of Paris where the government had less concern. The Sacco-Vanzetti riots openly challenged French laws and left-wing supporters and the conservative right fought for their public ground. In continued leftist protests after the initial night of riots, American sites remained a main target. Parisian police anticipated the inevitable anti-Americanism in the execution protests. In addition to providing extra security at the embassy, they also posted guards at American banks and other formal institutions. ${ }^{110}$ Leftists understood this obstacle and targeted more abstract American sites in Paris than tangible sites-primarily places where Americans spent money. ${ }^{111}$

Leftist protestors severely damaged their cause during the riots when they desecrated the French memory of their own fallen son. During the first night of violence, French communists were pushed from the American Embassy and marched to the nearby Tomb of the Unknown Soldier at the Arc-de-Triomphe. They occupied the space, sang the Internationale, disturbed wreaths, and overturned the chained barrier. ${ }^{112}$ This attack was likely based more on resentment of the leniency the government showed right-wing veterans groups than disrespect for the French unknown. Regardless of the motive, the communist protestors who attacked the resting place of France's most sacred body made a mistake. Over 10,000 French veterans reoccupied the space in silence the next day. Police did not involve themselves in this movement, hoping that the communist demonstrators might be rash enough to stand up

\footnotetext{
110 Ibid., 123.

111 Ibid.

112 "French Sympathy Swings to Legion," New York Times, August 26, 1927, in Proquest Historical Newspapers and Blower, Becoming American, 117.
} 
to the war veterans..$^{113}$ Americans viewed French veterans somewhat negatively due to their large Fourth of July protest the previous year, however, desecration of the Tomb of the Unknown prompted major support across the Atlantic. The American press widely circulated a report that the first person on the scene after communists desecrated the tomb was an American. According to the New York Times, an American veteran happened to be nearby while the communists engaged in their profanity. He "stood watching, his blood boiling, unable to intervene in the face of overwhelming numbers."114 He went to work replacing the wreaths and effacing the work of the communists as soon as they left. When French police arrived on the scene, he stopped his work long enough to report only that he "was a friend of France."115

In such massive riot against the United States, no damage happened at American military cemeteries in France, even at Suresnes on the outskirts of Paris. A couple of factors might explain the sparing of American cemeteries from the protest. It is quite possible that communist protestors anticipated a strong police presence at such a visible American site near Paris. Thomas North, an ABMC administrator in Paris during the riots, reported in his memoirs that much work went into distancing American cemeteries and memorials from political strife. North wrote that in dealing with local communities it was almost always pointed out to locals that the sites "concerned the host of American veterans who had nothing whatever to do with the Sacco-Vanzetti trials, and very little with the war debts." ${ }^{116}$ This preemptive branding of cemeteries as non-aggressive possibly made local protestors turn elsewhere to make a

\footnotetext{
${ }_{113}$ "Veterans Reply to Radicals," The New York Times, August 27, 1927, in Proquest Historical Newspapers.

114 Ibid.

115 Ibid.

116 Thomas North, One Soldier's Story, I-17.
} 
message. The advert political speeches that Myron Herrick gave at Suresnes during this period makes this explanation less satisfying. Another possible explanation is the strength of the discourse emanating from these sacred sites. The sacred divide separating the living and the dead of the Great War, American or French, was a line generally not crossed. The lack of reported vandalism in such a large protest is telling of the symbolic power of these sites.

American military cemeteries escaped communist protest unscathed and showed the power of the discourse that American policy makers had methodically bolstered since the closing of the Great War. Consequently, the communist attack on French military remains created a means for Americans to reciprocate French respect for their remains. In this period of great unrest, the diplomacy of American military memory thrived. Thousands more veterans joined the lone American who first arrived on the scene of the communist vandalism in the upcoming days. The day after the communist protest at the Arc, an American present for the French veterans' rebuttal reported that "those who saw the ceremony will not soon forget the impressive manner in which patriotic Paris repaired the insult to its unknown poilu."117 Large contingents of American Legion members stood in the crowd watching French veterans protect the tomb. The French press reported that the French felt honored that American veterans paid them such respect. American Legionnaires, present in France for a month long convention, furthered America's commitment to French memory by participating in the "purification ceremony" of the Arc and initiating a daily ritual of having American

117 "Veterans Reply to Radicals," The New York Times, August 27, 1927, in Proquest Historical Newspapers. 
legionnaires place flowers on the Tomb of the Unknown. ${ }^{118}$ The unified FrancoAmerican response to the communist defamation of the sacred memory brought the two cultures together and reaffirmed their commitment to shared democratic values. These reciprocal actions further advance the powerful bonds that war remains can perpetuate between nations.

Communist leaders also spoke out against the French communists actions at the Tomb of the Unknown. It was reported that Soviet chiefs in Moscow were quite disappointed in French communist leaders for allowing such a desecration to take place in the name of anti-Americanism. The displeasure stemmed from ongoing oil agreements between American companies and Russia. Moscow reportedly directed leaders in other nations to do "anything they liked against their own Government," so long as "no anti-American bias" was given in the protest. ${ }^{119}$ French communists failed this mission. Even though they attacked the memory of their own soldier, the manifestation was seen as an attack on the United States. The result of the protest was a more united front between the governments of France and the United States. A strong presences of French and American Great War memory around Paris provided both nations a means to engage positively with one another during the waves of antiAmericanism.

118 "Legion to Decorate French Tomb Daily," The New York Times, August 38, 1927, in Proquest Historical Newspapers.

119 "Veterans Reply to Radicals," The New York Times, August 27, 1927, in Proquest Historical Newspapers. 


\section{The Second A.E.F.}

The Sacco-Vanzetti riots came at an opportune time for American and French veterans to interact with each other through similar memories. The riots took place in August 1927. A few weeks later, on September 16, the start of the first large scale international meeting of American Legionnaires began in Paris. Many eager American veterans already walked the streets of Paris during the August riots. When the meeting commenced, some ten to twenty-four thousand American veterans descended on Paris representing every state in the Union. Although sacred, the pilgrimage certainly possessed elements of a leisurely vacation. American newspapers reported French preparations: "The Opera Comique and a dose of other theaters had gala performances for the former doughboys. Montmartre had laid in thousands of extra bottles of champagne and the more modest dancing establishments of the Latin Quarter were prepared for a record ten days." 120 The most important aspect of the meeting, however, was its spiritual and diplomatic meanings.

American soldiers fought with French and Italian veterans on European battlefields against Germans. French and American forces also united to fight Russian Bolsheviks in the Polar Bear Expedition at the conclusion of the Great War. Veterans groups shared a similar experience and similarly felt disillusionment at the outcome of their war. They also felt a continued obligation to protect their countries should a threat rise. This bond is evident in hopes of French veterans during their July 1926 protest that their American comrades in arms might come to their cause. The American

\footnotetext{
120 "France Welcomes Pershing at Head of Second A.E.F.," The New York Times, September 17, 1927, in Proquest Historical Newspapers.
} 
Legion's massive 1927 international meeting in Paris was a time when the bonds between veterans was strengthened.

American veterans planned to rekindle old friendships, visit battlefields, find comrades' graves, and also to show support to the French veterans they fought with during their 1927 meeting. France and America touted the event as the coming of the "Second A.E.F."121 Quite literally, former American doughboys came to reunite with those left behind. Howard Savage, the American Legion's National Commander, talked of the significance of the event after his warm reception in Paris. "When we [American veterans] go back France we will count among us Americans millions of friends whose friendship has been given that new life which all friendships need after the parties involved have been separated nearly ten years." ${ }^{122}$ Savage felt that the Legion's presence in France would remedy the sweeping anti-American sentiments of late. Savage had reason to believe that Legionnaires might find a positive experience. Throughout 1926, conservative voices in France assured Americans of their welcome in 1927, despite the negative press. Respect for the dead often acted as the vehicle to make this promise. French veterans groups largely looked forward to the pilgrimage. In 1926, the President of a disabled French veterans group called the "Broken Jaws," visited the United States to place a wreath on the Tomb of the Unknown Soldier in Arlington. Afterwards he invited all American veterans to make the pilgrimage next year "to the graves of our dead on the battlefields, to tell them not to believe lying tongues which say my country has received Americans badly and that peace henceforth will put an end to the

${ }^{121}$ Ibid.

122 Ibid. 
admirable comradeship of the war."123 Days later, French Minister of the Interior, Albert Sarraut, responded to inquiries from the Indianapolis News about the type of reception American veteran should expect in the upcoming pilgrimage. "The welcome they will receive will be as spontaneous and as enthusiastic as can be conceived," Sarraut assured. He went on to note that the recent anti-Americanism regarding debt and Sacco-Vanzetti was "entirely apart from our affection and admiration for the American soldier." 124 Anti-Americanism was "transitory," but respect for America's role in the Great War "permanent." 125 Sarraut ended his interview responding to "abominable fables" from "hostile propagandists" alleging the "desecration of the tombs of American soldiers in France." 126 When legionnaires visited American tombs in the upcoming years, Sarraut expected their experience to coincide with his personal observations in American cemeteries at Suresnes and Meuse-Argonne. "Frenchmen respect American graves to such an extent that they do not even walk on the grass, they visit with their heads uncovered and speak in whispers." ${ }^{127}$

The Great War dead of both France and the United States certainly served as a primary medium for the nations to engage one another during the Legion's 1927 pilgrimage. Within hours of arriving in Paris the leaders of the American Legionnaires, General Pershing, and Commander Savage, traveled to Arc de Triomphe to pay respects to France's Unknown Soldier. This moment was highly symbolic. The American delegation converged on the sacred French site to show that America had not forgotten

\footnotetext{
${ }_{123}$ "To Put Palm on Tomb of Unknown Soldier," The New York Times, October 2, 1926, in Proquest Historical Newspapers.

124 “Assures Big Welcome for Legion in France," Indianapolis News, October 11, 1926, in Proquest

Historical Newspapers.

125 Ibid.

126 Ibid.

127 Ibid.
} 
its ally. Pershing and Savage walked around the site in silence for several minutes after placing a bronze wreath on the tomb. This was a stark contrast to the communist protest that had taken place at the same spot only weeks ago. Thousands of French men and women surrounded the Americans throughout the somber moment. ${ }^{128}$

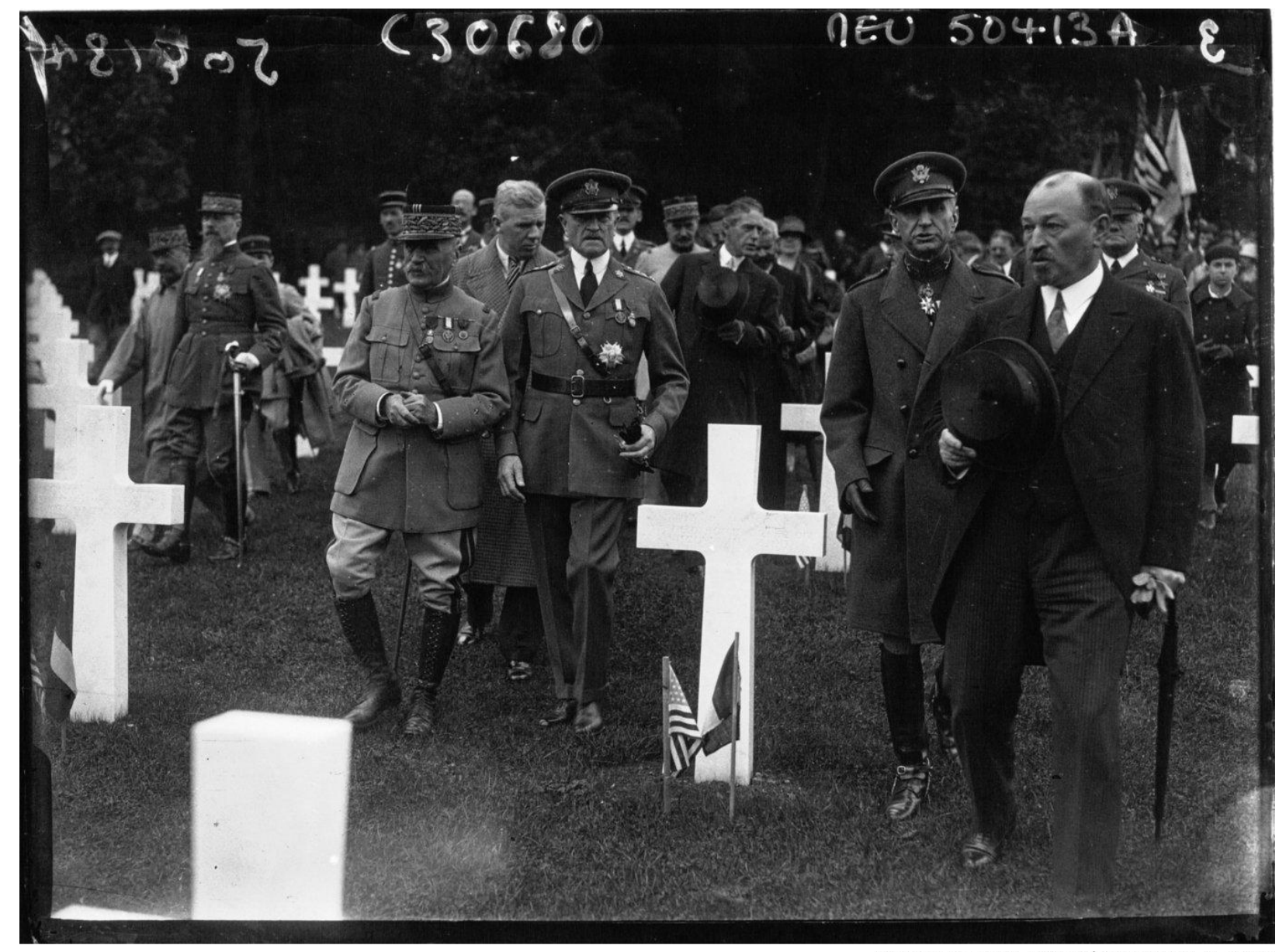

Photo 2.3: Foch, Pershing and Savage at Suresnes in September 1927, Source: Bibliothèque nationale de France, département Estampes et photographie, online archives.

Pershing, Savage and Marshal Foch then led the delegation to the American cemetery at Suresnes the following day to similarly pay respect for American remains prior to the commencement of festivities that marked the reunion's start. Pershing

128 "France Welcomes Pershing at Head of 'Second A.E.F.," The New York Times, September 17, 1927, in Proquest Historical Newspapers. 
began the ceremony, honoring the remains which he had commanded. Speaking as a soldier, and for his soldiers, Pershing noted that they could not "ask for a sweeter resting place than on the field of glory where they fell." He explained to the dead that they had "become a symbol of mutual gratitude" with "the people of two nations watching over them."129 Marshal Foch followed, addressing the crowd on behalf of France. His voice cracking with emotion, Foch stressed that thanks that France held for these young men who abandoned their lives to stand with France "defending an ideal which was alike their and ours." 130 The most moving speech of the day from Commander Savage followed. After several moments of fighting back tears, Savage began by telling the crowd his words were not for them. He addressed "his comrades in death," all 30,000 spread throughout France. ${ }^{131}$ Savage felt regret that he survived and left them for "nine years," albeit it "in the tender care of a sister nation. ${ }^{132}$ Savage then outlined that the Legion was in France to commune with the dead. American veterans should interact with the dead and reflect on their own lives. Through this introspection, each veteran could determine if their dead comrades approved of the life they lived. Savage felt assurance when he looked at the crosses. The dead wanted their grieving families cared for, a powerful nation able to stand up for mankind, and a just nation that retained international confidence. ${ }^{133}$ International events since the Great War showed that fulfilment of these wishes still had far to go. Nonetheless, he felt that the dead understood that their living "buddies" were doing all they could and "fighting the good

\footnotetext{
129 "Legionaires Honor on Eve of Reunion Comrades Who Died," The New York Times, September 18, 1927, in Proquest Historical Newspapers.

130 Ibid.

${ }^{131}$ Ibid.

132 Ibid.

133 Ibid.
} 
fight." 34 At the conclusion of the speech, Savage led the delegation back to the Tomb of the Unknown where he trimmed the wick of the eternal flame. This was a coveted assignment in French culture, and that he was allowed to perform it showed the "greatest token of friendship and confidence."135

The opening communions with military dead set a tone for the event. The American veterans' primary task was to serve as the face of American memory. In the upcoming days, they were supposed to keep in mind the comrades who could not join in the festivities. Likewise, their actions should respect the memory of the dead and improve relationships with the living. This proved somewhat difficult, however, because much of France divided on the American assembly. The split in France primarily coincided with political leanings. Right leaning French, namely veterans associations, welcomed their American counterparts. The American Legion's response to the attack on the Tomb of the Unknown improved this sentiment. Those French who supported the left, primarily communists, resented the American presence. Only weeks ago, they engaged in destructive anti-American protest. Parisian police had barred them from protesting in the public spaces of their own city and violently repelled them, yet they allowed the American foreigners to occupy the same space closed to them. ${ }^{136}$ Ideologies split Parisian perceptions on the American veterans, still apprehension likely resided in almost all French. The tone of the American presence was inherently militaristic. The veterans heralded themselves the second American Army, they literally intended to take over the city. The New York Times reported that "the city of Paris, the pride of all Frenchmen, is literally being given over to the American veterans for the next ten

\footnotetext{
134 Ibid.

135 Ibid.

${ }^{136}$ Blower, Becoming Americans, 179.
} 
days."137 Parisians had not forgotten animosity towards American debt policy and feared the encroachment of American culture. They also anticipated the inevitable American drunkenness, ignorance of French customs, arrogance, and advances on French women. The headline event of Legion's pilgrimage, a military style parade would be the ultimate test of French tolerance for the event.

The Legion's parade was set for the day after the speeches at Suresnes. The American veterans split based on their home states and marched through the most notable locations of Paris going through the Arc de Triomphe, and passing a review stand manned by Pershing, Foch, and Savage. At the end, they congregated near George Washington's statue and the American Embassy. ${ }^{138}$ The notion of such a political display infuriated communists. The French government continually denied them this type of manifestation to the left. Additionally, it seemed eerily reminiscent to the French veteran protests that the French government frequently allowed to take place. The communists' newspaper L'Humanité provided a scathing critique of the American parade. The communists viewed the legionnaires as a "Puritan and alcoholic fascist Legion," "a band of lynchers from the South," and "fascist ASSASSINS OF SACCO AND VANZETTI."139 The 30,000 American veterans would likely see great support and American flags during their parade, but only because they "concentrated in a few middle-class neighborhoods in the boulevards" of Paris where "work has no place." 140 The paper warned French communists to control their impulse to seek revenge for the

137 "France Welcomes Pershing at Head of 'Second A.E.F.,"” The New York Times, September 17, 1927, in Proquest Historical Newspapers.

${ }_{138}$ Blower, Becoming Americans, 179.

139 Vaillant-Couturier, "Legionnaires Assassins," L'Humanité, September 19, 1927, in digital archives of Bibliothèque Nationale de France. 140 Ibid. 
Sacco-Vanzetti executions. The right-wing French government wanted this to happen, and was using the parade to set up a "deadly ambush" of French workers. The American veterans marched through Paris "under the protection of batons, guns, and armored cars." ${ }^{41}$

The predictions in L'Humanité proved true. No major disturbances took place during the parade. Communists avoided the perceived ambush and set aside their own day in the future for protest. American flags did saturate the streets, even adorning the Eifel Tower. ${ }^{142}$ The biggest problem raised by the parade was the tone of the legionnaires. Instead of assuming the role of militant fascists, they thoroughly enjoyed the day and treated it as a celebration. ${ }^{143}$ Parisians stood shocked as American veterans embraced the uniqueness of their states and displayed local symbols. There were women dressed as the statues of liberty, Native Americans, cowboys, and sombrero clad veterans. ${ }^{144}$ The American memory diplomats marching in the parade showed the French their innocence, fun loving nature, and individuality. This likely had a somewhat negative effect on the French due to their own memory of the war. The Great War "had not been a grand parade or a circus in motion" and some found the lightness projected by Americans offensive. ${ }^{145}$ Still, in the turbulent 1920s, memory and care for Great War dead proved itself a viable means for France and America to interact.

Although the Legionnaires indulged in too much festivity at times during their occupation of Paris, the convention successfully continued the positive relations between the two nations-particularly between national governments and veterans'

\footnotetext{
${ }^{141}$ Ibid.

142 Blower, Becoming Americans, 195.

143 Ibid., 198.

144 Ibid.

145 Ibid., 199.
} 
groups. ${ }^{146}$ The New York Times reported that the "visit seems to have completely wiped out the anti-American sentiment which arose from the Sacco-Vanzetti agitation." 147 Many French at the start of the convention felt confused when the somber pilgrimages to U.S. graves that started the convention transformed into a "more joyous excursion" as the month progressed. ${ }^{148}$ The festive spirit of American veterans eventually won the French over and lifted the spirits of Paris. American veterans representing their government, and Parisians not associated with leftist groups, related to one another during the pilgrimage through their shared memories. Left-wing protest that attacked the memory of French soldier dead during the Sacco-Vanzetti riots actually served to bind the veterans from each nation. The success of the Legion's pilgrimage caused an international surge in battlefield visits to France. Part of this is surely due to the warm reception American veterans received abroad. Antics of American veterans also generated hostility among the French. ${ }^{149}$ The fun loving nature of Americans veterans in Paris stirred many Europeans into believing that memories of the war "were weakening or had become tainted by" American “cultural lightheartedness.” 150

146 “Anti-American Feeling Changed by Legion to Great Cordiality and Good Fellowship," The New York Times, September 22, 1927, in Proquest Historical Newspapers.

147 Ibid.

148 Ibid.

149 Lisa Budreau, Bodies of War, 190.

${ }^{150}$ Ibid., 190. 


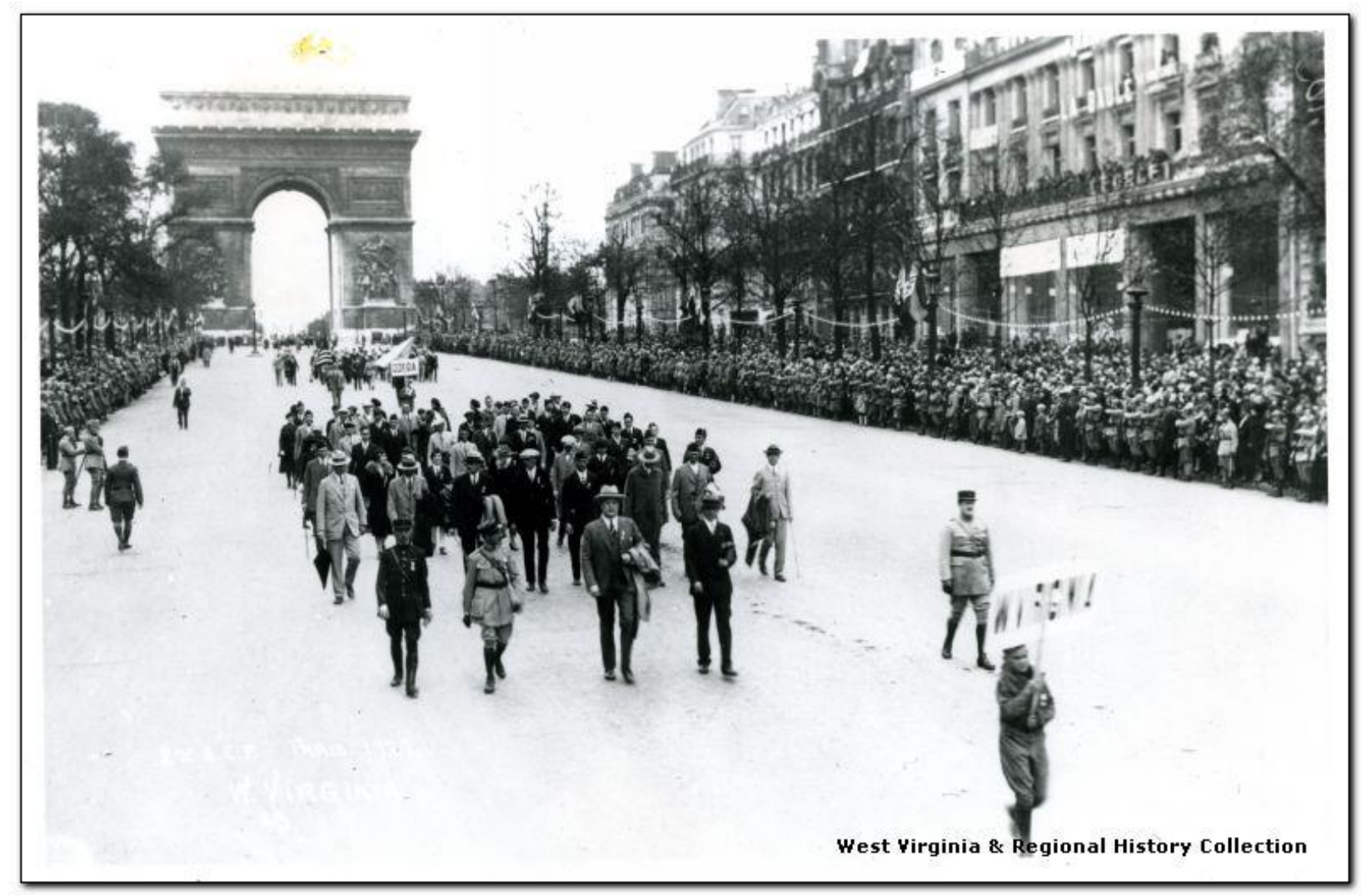

Photo 2.4: West Virginia's Delegation Marching in American Legion Parade, September 19, 1927. Source: West Virginia Regional History Collection, West Virginia University, Morgantown, WV. Note that the delegation was not in costume.

\section{$\underline{\text { Conclusion }}$}

Interaction with sites of French and American military dead allowed both nations to engage with each other during the first decade of the interwar. During this period of high anti-Americanism in France due to resentment over war debt policies and total disdain for leftist politics, sites of memory became platforms to assert future aspirations. American leaders used their sites of the dead to remind France that even though times were hard, America was committed to their longevity and France still owed them for sacrifice. The French government used these sites in a similar manner. 
American remains became a way for the government and average French person to distance themselves from radicalism. Care and reverence for American remains showed Americans that the French too were committed to a sustained relationship in the future.

It is telling that no real French desecration of American military graves or protest at American military cemeteries took place in France during this highly volatile period. Instead, French radicals chose to use the memory of their own military remains to make political statements. This in turn, allowed Americans to stand with French veterans and right-minded French to reciprocate amicable feelings. American and French military dead served as a bridge between a deep political gulfs between nations.

The French feared the repercussions of American culture coming to their shores. A future of a diminished Old World and powerful New World was a scary prospect. While American military remains represented that type of future in France, they somehow represented a less frightening part of that future. And, in the second portion of the interwar years, the future these remains represented provided a sense of comfort. The far from fascist American legion that some Parisians feared in 1927 was overshadowed by very real fascists legions from Italy and Germany in the 1930s. As the stability of the Treaty of Versailles eroded quickly though the 1930s, American military remains in France showed a shared commitment to preserving peace and offered the French hope that should another war come, living American soldiers would come again. 


\section{Remains of Peace: U.S. Remains and the Coming of World War II}

The companionship of sorrow is more enduring than the comradeship of victory. ${ }^{1}$

The aggressive domestic and foreign policy of Fascist Italy and Nazi Germany in the 1930 s forced American memory abroad to return to a more liberal Wilsonian vision of peace. The completion of American military cemeteries in France, and subsequent dedication ceremonies, coincided with the rise of European political unrest. Completed ABMC cemeteries became locations where the United States and France could invoke peaceful messages as needed. Finalization of ABMC cemeteries also coincided with increased drive from Washington to find new means to conduct international relations. Through the 1930s, it was evident that one of the most viable mediums for the United States to engage with other nations was through "public participation;" or letting ordinary citizens travel abroad and project America onto other landscapes. ${ }^{2}$ A visible example of

\footnotetext{
${ }^{1}$ Fiorella La Guardia, "Hearing Before A Subcommittee of the Committee on Military Affairs United States Senate, Seventieth Congress, First Session, on H.R. 5494, Bill to Enable the Mothers and Unmarried Widows of the Deceased Soldiers, Sailors, and Marines of the American Forces Interred in the Cemeteries of Europe to Make a Pilgrimage to these Cemeteries," May 141928 (Washington, DC: Government Printing Office, 1928), Part I, 13-14.

${ }^{2}$ Justin Hart, Empire of Ideas: The Origins of Public Diplomacy and the Transformation of U.S. Foreign Policy (New York: Oxford University Press, 2013), 6-10. Spreading a specific image of America for public consumption was not new in the 1930s. However, some scholars mark the 1930 s as the period when sophisticated cultural transfer programs, more commonly attributed to the Cold War, emerged in the United States. During the Great War, the Congress created the Committee of Public Information (CPI) to utilize new forms of mass media and spread messages of American capability both at home and abroad. The CPI functioned as the first federally sponsored propaganda machine of the United States. Through motion pictures, mass publications, and radio broadcasts the CPI attempted to improve foreign opinions of America and contribute to the war effort. While by most accounts effective, the CPI faced public backlash in the United States for its "heavy handedness." President Wilson discontinued the agency at the conclusion of World War I. Many Americans felt that a propaganda machine like the CPI had a place in democratic society only during times of war. The stoppage of the CPI also indicated that Washington did not yet grasp the importance of cultural perceptions in diplomatic relations following World War I. This does not mean an absence of American cultural transfer abroad. Americans citizens and businesses took their way of life to France throughout the 1920s. But, for the most part, the United States government
} 
this was the three-year long Congressional sponsored program that sent American mothers and widows of deceased doughboys abroad to visit their graves. These women effectively mobilized their new political power to gain not only a government sponsored mourning trip, but also a chance to serve their nation as public diplomats. Mathilda Burling, the mother of George Burling Jr., a deceased soldier from New York buried in St. Mihiel American cemetery, was one of the most vocal lobbyists for Gold Star Pilgrimages. Mrs. Burling pleaded with U.S. Senators in May 1928 to give her a visit the grave of her only son. ${ }^{3}$ Burling grieved for her son and understood that nothing could replace him. Still, she felt that she could serve her government through her son's memory. "What a wonderful peace mission it would be if such a group of mothers could be sent abroad... I believe it would bring the countries closer together than any act that could ever be suggested," offered Burling.4 As international stability deteriorated through the 1930s, U.S. bodies in Europe morphed into beacons of peace more so than ever before.

Getting Americans abroad to visit U.S. military remains served as only one example of working for peace. As the United States constructed a peaceful message of memory in France through pilgrims and dedications, it navigated a more sensitive memory situation with the Soviet Union. From the mid-1920s through the 1930s, officials

adopted a dismissive attitude towards the uses of propaganda to improve its image abroad during the decade after the Great War. This passive attitude towards cultural transfer changed in the early 1930 . Much of this shift came as a result of active propaganda campaigns from European nations. Great Britain and France aggressively projected messages of their culture abroad to colonial populations. Germany and Italy used propaganda to expand their imperial reach. The Soviet Union promoted its proletarian revolution. Vocal propaganda from international players forced the United States increase its own efforts to shape an official image to others. Also important to the increase in American propaganda was World War II. This conflict ultimately served as a watershed event for America's cultural transfer programs. American military cemeteries effectively served as a vehicle for the propulsion of American culture into Europe in the nascent period of public diplomacy. Washington's treatment of its World War I remains abroad in the interwar period helped focus the new effort to improve the American image in the build up to World War II.

3 Mathilda Burling, "Hearing Before A Subcommittee of the Committee on Military Affairs," May 141928 , Part I, 4 .

4 Ibid., 5 . 
in Washington maneuvered to get U.S. Army personnel on the ground in the Russian subArctic to remove the remains of American soldiers killed fighting Bolsheviks during the Polar Bear expedition of 1918-1919. While the presence of American bodies in French soil showed friendship, the strong desire to remove American bodies from Russian soil showed animosity. French soil was conceptualized as friendly, Russian soil as diseased. The final expedition to remove American remains from Russian earth in the 1930s illustrated the strained relationship between the United States and the Soviet Union. Yet, it also signaled some improvement in relations. Removing the bodies of American invaders from Soviet soil would help erase a negative memory from the Russian landscape. The mere fact that the governments in Moscow and Washington opened a dialogue to remove American bodies also showed improvement from the diplomatic silence of the 1920s. The final section of this chapter examines the diplomatic uses of this more negative U.S. memories in foreign countries. This is a useful contrast to the overwhelming positive rhetoric seen in U.S. memories on French soil. 


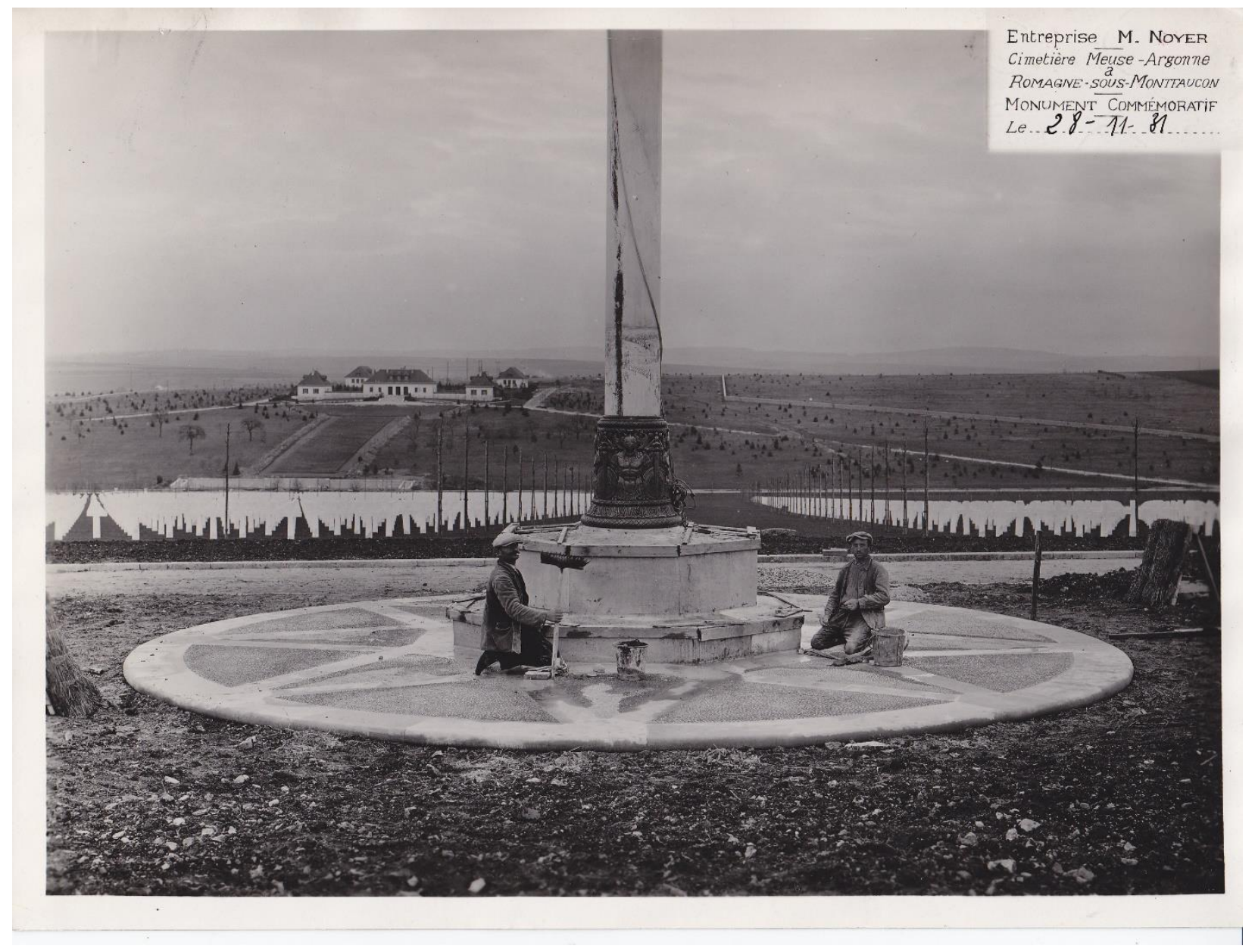

Photo 3.1: French Laborers completing masonry work on Meuse Argonne American Cemetery flagpole, November 1928. Source: RG 117 National Archives.

\section{Diplomatic Pilgrims}

The 1927 American Legion pilgrimage was not the only one of its kind that Americans partook in through the interwar years-although it was the one that incorporated considerable elements of martial manliness. From 1930 through 1933, contingents of American female mourners arrived in France on federally sponsored pilgrimages. At a cost of over five-million dollars, approximately 7,000 American mothers and widows, traveled to Europe to visit the graves of the dead they relinquished 
to their government.5 These Gold Star Mother pilgrimages stand out in American history. After no other American military conflict, including WWII, did the federal government take on the financial burden of sending American women to the graves of their sons, daughters, and husbands. The pilgrimages also happened during the height of the Great Depression. This was indicative of the importance that American society placed on catering to the needs of grieving American women. In this nascent period of female suffrage, American women effectively mobilized their political power to make their pilgrimages happen. Support for the pilgrimages rested mainly on long standing notions of republican motherhood present in the United States-meaning that the sacrifices of American women for their republic fostered national preservation just as much as martial manhood. 6

Historians have analyzed the Gold Star pilgrimages primarily through the lens of gender and race. At their most basic level, the pilgrimages do highlight the stereotypical twentieth century conceptions of female fragility and need for masculine care. Notions that grieving women, not men, deserved a pilgrimage to graves abroad showed the perceived delicacy of their sex. Male leaders in Washington planned for the female pilgrims' care at every step. Invitations went to the women the government deemed eligible, their travel was taken care of, and the month-long trip took place in luxury the majority of women had no experience with. Each pilgrim also had access to a team of nurses and guided tours by Army officers. American Gold Star Mothers received vigilant care, but certainly were not complacent in the pilgrimage process. They proved

\footnotetext{
5 Budreau, Bodies of War, 207.

${ }^{6}$ To see other examples of females engaging in international relations in this period see David Patterson, The Search for Negotiated Peace: Women's Activism and Citizen Diplomacy in World War I (New York: Routledge, 2008).
} 
particularly adept at equating the sacrifice their sons made to the sacrifice they made by allowing their son to fight. It was not merely that female mourners required a pilgrimage for closure more so than men, but they effectively argued that maternal loss garnered a "privileged status," deserving more empathy than sacrifices made by fathers, or even widows. 7 It was the pilgrims themselves that mobilized the political momentum to make the trips happen.

Race also played a visible role in the Gold Star pilgrimages. The American Battle Monuments Commission adopted desegregated burial practices, but American women visited those graves under the prevailing customs of Jim Crow. Congress ultimately decided that white pilgrims and black pilgrims should not travel together, but promised that "no discrimination whatsoever" would be made and that "each group would receive equal accommodations, care, and consideration." 8 This was primarily justified by the cultural inability of American passenger ships to accommodate both races equally on the same voyage. African Americans did receive hospitable treatment throughout their voyages, but it was far from equal. They traveled on less luxurious vessels, were kept off of white train cars in France (American policy), assigned special black nurses and guides, and inundated with white American typecastss-like being greeted by black jazz musicians and fed meals of fried chicken and imported watermelon. 9 Of the approximately 1,600 African American women possibly eligible for the trip, only a few

\footnotetext{
7 Lisa Budreau, "The Politics of Remembrance: The Gold Star Mothers' Pilgrimage and America's Fading Memory of the Great War," The Journal of Military History, Vol. 72, No. 2, April 2008, 393. Mothers and widows (who did not remarry) received top priority. Remarried widows were completely disqualified.

8 Budreau,"Politics of Remembrance," 401.

9 Ibid., 400. Also see "Gold Star Negroes Welcomed in Paris," The New York Times, July 22, 1930

inProquest Historical Newspapers.
} 
hundred met the requirements established requirements for the trip. ${ }^{10}$ Among the select few, even fewer opted to make the segregated pilgrimage.

Many refused to go because of the blatant racism and hypocrisy of the government. A petition from African American mothers to President Hoover stated that they felt "Jim Crowed, separated and insulted" by the "implication that we are not fit persons to travel with other bereaved ones."11 It made no sense that black and white soldiers sacrificed equally on the field, but American mothers with different shades of skin could not mourn over graves together. ${ }^{12}$ An African American soldier of Great War wrote the War Department to protest the segregation of Gold Star mothers. He asked "is not your dead colored soldier's grave worth as much as the white? Do you believe the Lord admitted these boys' souls into heave thru separate gates?"13 The ex-soldier feared what his government's racist segregationist pilgrimages might do to his country's international image. "When our country shows no respect towards us, what does she expect other countries to show towards us and our gold star mothers?"14 Despite this veteran's fears that black mothers might face racism abroad, African American mothers only encountered Jim Crow in France through the policies of their own government. Not all African American pilgrims felt hostility towards the segregated policies. Ellen Slaughter, a mother from Texas felt not shame towards her government, but "pride" that Congress allowed her to travel in "comfort," treated her "courteously," and maintained her son's

\footnotetext{
10 Ibid.

${ }_{11}$ "Capital Rebuffs Gold Star Negroes," The New York Times, May 30, 1930, inProquest Historical Newspapers.

12 Budreau,"Politics of Remembrance," 402-403.

13 Ex Soldier to Quartermaster General, March 10, 1930, "Colored Gold Star Mother Files," Quartermaster Records, RG 92, NARA.

14 Ibid.
} 
grave. ${ }^{15}$ Slaughter's gratitude toward her country could not even be contained until she returned home from the trip. She wrote her thanks while at sea, eagerly waiting to reunite with her son.

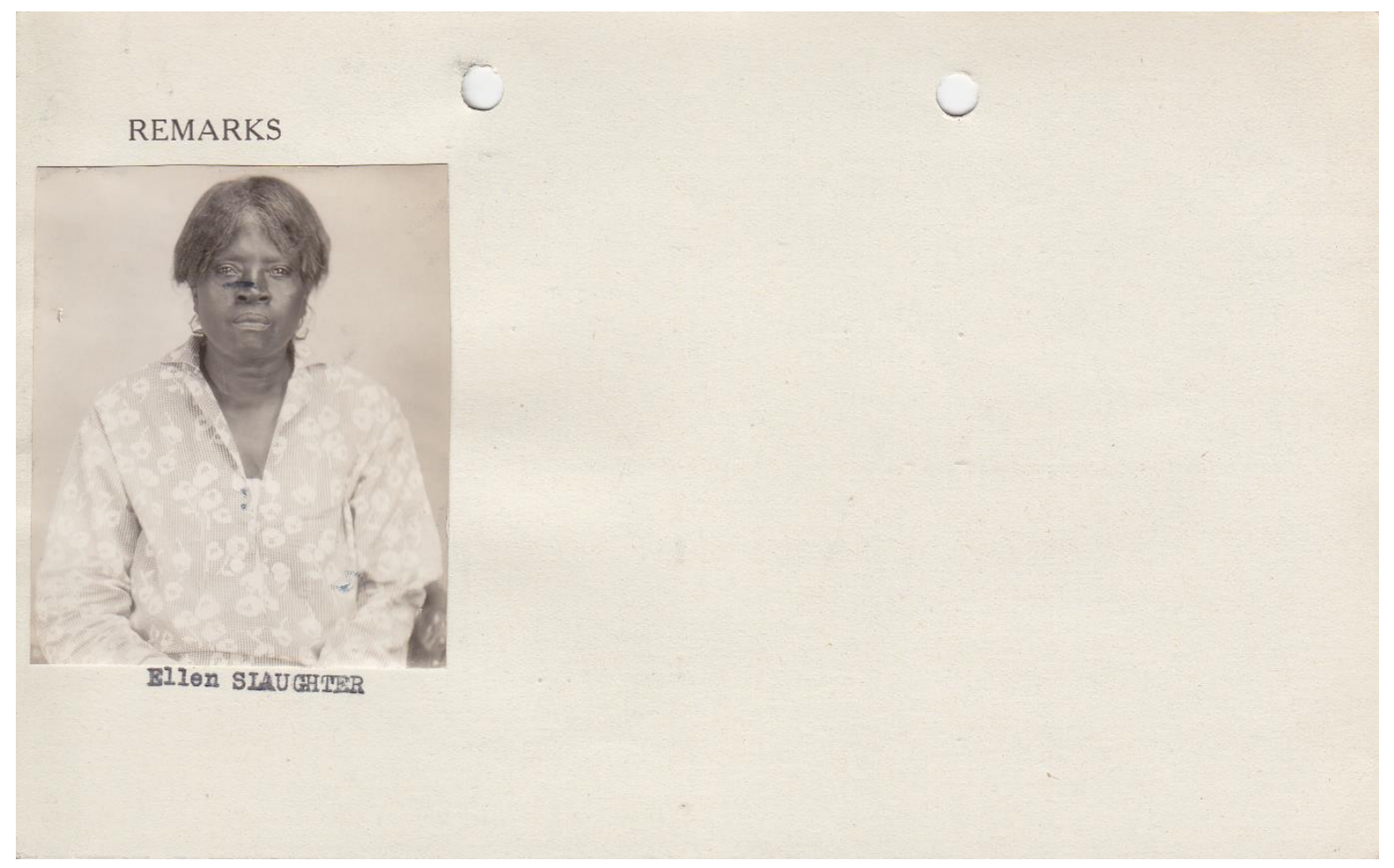

Photo 3.2: Passport Photograph of Gold Star Mother Ellen Slaughter. Source: RG 92, NARA. (From burial file of Jim Hughett, files now at National Personnel Records Center, NPRC, in St. Louis, Missouri). Gold Star Mothers who participated in the War Department's pilgrimages typically have a passport photograph like this included in their son's or husband's burial file.

From all accounts, the French treated black American mothers as equals, just as they had welcomed African American veterans following the Great War. ${ }^{16}$ When the African American Gold Star Mothers arrived at the Arc de Triomphe they were greeted by

15 Ellen Slaughter to Quartermaster Division, July 19, 1930, Box 2398, WWI Burial File of Jim Hughett, Quartermaster Records, RG 92, NARA (files now at National Personnel Records Center, NPRC, in St. Louis, Missouri).

16 "Gouraud Welcomes Gold Star Negroes," The New York Times July 23, 1930 in Proquest Historical Newspapers. 
a large crowd of French spectators and hundreds of African American expatriates from the United States. Despite the racism of their country, influential American leaders such as Ambassador Edge and General Pershing often dined with the black pilgrims after their arrival to Paris. ${ }^{17}$ African American pilgrims kept the memory alive of their sacred remains just as white women. The experience that they took from the European trip was fundamentally different than that of their white counterparts, however. In Europe, most African American women experienced their first taste of "true freedom."18 One African American mother returned home with an understanding that blacks could "live in the same hotels, eat in the same restaurants, travel in the same conveyances, and get along when they will with the same tranquility and the colored and the white dead laying side by side in the cemeteries they visited." 19 In the upcoming decades, American racism increasingly became an international issue. Some historians go so far to argue that the changes brought by the civil rights movements of the 1960 s moved more rapidly because of government fear of negative foreign perceptions of a hypocritical United States. ${ }^{20}$

The Gold Star Pilgrimages represent more in American history than an early example of American women asserting themselves politically. Furthermore, they were not just a case study of the fractured democratic American society in the interwar era. Taking a step back from these important issues and analyzing the basic function of the pilgrimages reveals diplomatic undertones. Part of the American government's intent with the pilgrimages was to get American women on the soil of Europe to mourn. This is

\footnotetext{
${ }_{17}$ Ibid. And "Negro War Mothers Welcomed in Paris," They New York Times, June 9, 1931 inProquest Historical Newspapers.

${ }^{18}$ Lisa Budreau, "The Politics of Remembrance", 403.

19 Ibid., Quoting Mrs. W.D. Rush of Atlanta, interviewed by the Afro-American, August 9, 1930; from Gold Star Pilgrimages Scrapbook, Gold Star Mother Pilgrimage files, NARA II, College Park.

${ }^{20}$ Mary Dudziak, Cold War Civil Rights: Race and the Image of American Democracy (Princeton, New Jersey: Princeton University Press, 2000).
} 
yet another example of memory as a diplomatic tool started immediately after the Great War. American women travelling on a gift from their government served the national interest of their country. The final destination for each pilgrim was a shrine of memory that the federal government had created. The participation of American women in a standardized pilgrimage validated these sites and demonstrated to the French that presence of American soldier dead in their soil indeed meant an everlasting bond. American dead demanded continued Franco-American respect despite antiAmericanism, economic depression, and growing European militarism. The Gold Star Pilgrims contributed to this narrative of diplomacy, which required continual attention. Public statements from French Prime Minister Édouard Marie Herriot at the end of 1932 showed the timeliness of the Gold Star Pilgrimages.

By the 1930s, French leaders started to question if they sufficiently paid their debt of gratitude owed to America in the two decades after the war. In an address to France's Chamber of Deputies regarding war debt, Herriot noted from the outset that his country would never forget America's contribution to victory. Nor would France forget their emotional dues because of the "silent testimony of those 75,000 [American] graves" serving as constant reminders. ${ }^{21}$ Although the reminder of the dead demanded thanks from the French, "gratitude for the past" should not "prevent free men from speaking frankly to free citizens," in Herriot's opinion. ${ }^{22}$ Herriot indicated that American leaders, and previous French leaders, hid behind the comfortable discourse of the dead instead of engaging in frank talk. ${ }^{23}$ The presence of American Gold Star mothers brought a renewed

\footnotetext{
${ }_{21}$ "Premier Herriot's Speech on War Debts and Reparations in French Chamber," The New York Times, December 13, 1932 inProquest Historical Newspapers.

22 Ibid.

23 Ibid.
} 
focus on the discourse of the dead at a time when French leaders attempted to move beyond its strict parameters.

Testimony before the Senate Subcommittee on Military Affairs about passage of Gold Star Pilgrimage legislation revealed an understanding among leading women that their mission had foreign policy merit. New York mother Mathilda Burling's diplomatically slanted appeal for pilgrimages opened this chapter ${ }^{24}$ Another Gold Star Mother, Ethel Nock, similarly saw any pilgrimage she might make to her sons grave as a mission. She urged the Senate to reconsider allowing the American Red Cross to administrate the pilgrimages. Nock saw the proposed voyages as "sacred pilgrimages" that ought to be carried out on "a high plane" as a "crusade that would not only benefit mothers but make better relations between France and America." ${ }^{25}$ While the Red Cross did excellent work, Nock feared that the organization lacked the power to give the pilgrimages legitimacy. Nock worried that if the Red Cross handled the pilgrimages the likelihood of them becoming a "junket" increased dramatically. ${ }^{26}$ Nock felt that the pilgrims should only include mothers because the majority of widows sought only a "pleasure trip" with thoughts only of Paris. ${ }^{27}$ In Nock's assessment, the best way to preserve the sacredness of the pilgrimages was to relegate them to U.S. Army Quartermaster supervision. The pilgrimages were strictly a government endeavor and the most efficient government entity to move people was the U.S. Quartermaster. The Graves Registration Service that had handled all of the burials also fell under the

24 Mathilda Burling, "Hearing Before A Subcommittee of the Committee on Military Affairs United States Senate, Seventieth Congress, First Session, on H.R. 5494, ," May 14 1928, Part I, 4.

25 Ethel Nock, "Hearing Before A Subcommittee of the Committee on Military Affairs United States

Senate, Seventieth Congress, First Session, on H.R. 5494," May 14 1928, Part I, 9-10.

${ }^{26}$ Ibid.

27 Ibid., 10. 
Quartermaster Department. Therefore, it could best get mothers to the right graves. Nock acknowledged that if the uniformed officers handled the pilgrimages they would likely be more spartan than a Red Cross run voyage. This was a good thing. A true American pilgrim did not need comfort and luxury. She needed a "high type of courage" reflective of a mother who birthed the courageous heroes buried in Europe. ${ }^{28}$ These women planned to go abroad, engage with the memory of their dead child, and use the universal language of motherhood to improve international relations.

The rhetoric of these leading Gold Star Mothers clearly alluded to an understanding that their pilgrimages represented more than the fulfillment of a mother's needs. New York Congressman Fiorello La Guardia, who reached the height of his political fame as New York's mayor during the New Deal, aided the Gold Star Mothers' cause by further articulating the diplomatic importance of the proposed pilgrimages. La Guardia had served in Italy during World War I and cared deeply about the preservation of American memory abroad. He proposed funding pilgrimages shortly after the war, however, the heated battle over repatriation stifled his bill. With the growing support for pilgrimages evident in May 1928, La Guardia saw an opportunity for the United States Government to "not only give mothers relief," but also to "do a great deal of good for world peace." ${ }^{29}$ America had not ratified the Treaty of Versailles and never joined the League of Nations, but did support the Kellogg-Briand Peace Pact. America's mothers could do more for international peace than any formal agreement the United States had accepted since the Great War ended. In La Guardia's assessment, American mothers would come in contact with Gold Star mothers of France while abroad. Together, they would create a

\footnotetext{
${ }^{28}$ Ibid., 8.

29 Fiorella La Guardia, "Hearing Before A Subcommittee of the Committee on Military Affairs United States Senate, Seventieth Congress, First Session, on H.R. 5494," May 14 1928, Part I, 13-14.
} 
"common understanding that would be far more lasting than any peace treaty." 30 The pilgrimages transformed mothers of France and the United States into public diplomats. During this period of international turmoil, La Guardia felt that mothers going to visit remains would be "the best representatives that the United States could send to France" because they alone could help the international community realize the "uselessness of war." ${ }^{31}$ La Guardia aptly summed up the diplomatic uses of memory at the end of his testimony. The "companionship of sorrow is more enduring than the comradeship of victory." 32 The American remains left in France represented the nations' collective sorrow. The American memory of the dead united with the French memory to create an everlasting bond that the arrogance of victory could only fog.

Members of the Senate Committee of Military Affairs debated the diplomatic implications sending grieving Americans to France, and attempted organize them in the most beneficial way for the United States. Senator Hiram Bingham from Connecticut feared that if too many mourning American mothers arrived to France in one large group the effect would be negative. Americans living in France wrote Congress opposing such large excursions. They feared that the French would "totally misunderstand" massive pilgrimages.33 Instead of improving relations, large pilgrimages would sour them. The French would see the "flaunting of grief," and "displays of celebration" instead of genuine American mourning.34 To avoid the risk of insulting the French, small contingents of

\footnotetext{
30 Ibid., 14.

${ }^{31}$ Ibid.

$3^{2}$ Ibid.

33 Hiram Bingham, "Hearing Before A Subcommittee of the Committee on Military Affairs United States Senate, Seventieth Congress, First Session, on H.R. 5494, Bill to Enable the Mothers and Unmarried Widows of the Deceased Soldiers, Sailors, and Marines of the American Forces Interred in the Cemeteries of Europe to Make a Pilgrimage to these Cemeteries," February 12, 1929 (Washington, DC: Government Printing Office, 1928), Part II, 18.

34 Ibid.
} 
American woman traveled abroad.35 This hopefully would make the French less skeptical of American intentions, and spread out the time period in which American mothers would be a presence on the European memorial landscape.

The federal government spent considerable money to send these women abroad to interact with sites of memory and serve as public diplomats. The intent was not for the women to stand out as individuals, but to represent American sacrifice as a whole-the same as the graves they visited. American remains had been in France for over a decade by the time the first pilgrims arrived on French soil. The standardization and formality of pilgrimages helped revamp memories of American soldier dead. For three years, the French saw a continuous flow of American women among them. They stood out among the crowd: wearing purple arm bands monographed with 'pilgrim', riding in large touring buses, and following uniformed officers. The presence of American women signified that America really had not forgotten the commitments promised through the discourse of the dead. It was not desired for Gold Star pilgrimages to function like the legionnaires' 1927 reunion in Paris. No "display of celebration" or "flaunting of grief" should come from Gold Star women, said U.S. Congressmen in deliberations for funding. ${ }^{6}$ America's friends in France needed to understand these excursions, and not feel the confusion of the 1927 Legionnaires strange mix of mourning and festival. "The ranks of mothers and sweethearts" might remedy the memory of the 1927 veterans. ${ }^{37}$ New York Senator Robert Wagner imparted his hopes of the pilgrimage to fellow New Yorker, Congressman John

35 Ibid.

${ }^{36}$ John Thomas Taylor, "Hearing Before A Subcommittee of the Committee on Military Affairs United States Senate, Seventieth Congress, First Session, on H.R. 5494," February 12, 1929, Part II, 18. 37 Senator Robert F. Wagner to Congressman John J. Boylan, "Hearing Before A Subcommittee of the Committee on Military Affairs United States Senate, Seventieth Congress, First Session, on H.R. 5494," February 12, 1929, Part II, 27. 
Boylan. Wagner envisioned the Gold Star trips as "holy pilgrimages" of a "new expeditionary force" defending peace and recasting French perceptions of Americans. Gold Star women would show France that America was not "fighting doughboys" or "gallant legionnaires," but a "nation of homes and families whose members were capable of the most pious sentiments." 38

The regimented nature of the Gold Star Pilgrimages causes some to dismiss their ability to project true American culture abroad. The female participants had their itinerary planned for them, and found limited "opportunities to mingle socially and challenge national stereotypes." 39 Pilgrims' exposure to France was certainly more insulated than an independent traveler. ${ }^{40}$ Still, the pilgrimage of a Gold Star Mother lasted approximately a month, giving them considerable time in a foreign culture. After a weeklong trans-Atlantic voyage, female pilgrims underwent a briefing by a male Army officer in Paris and then collectively traveled to France's Tomb of the Unknown where one woman laid a ceremonial wreath. This respect for French soldier dead initiated every pilgrimage. They then spent three days in Paris going on guided tours and shopping trips. Following the initial touring and acclimation to France, the women divided up according the burial location of their family member and traveled together to the appropriate cemetery. The American government gave the women four days for the actual pilgrimage part of their trip. On each day of the mourning expedition, they made visits to the graves and engaged in whatever local sightseeing was available. This often included visits to the

\footnotetext{
${ }^{38}$ Senator Robert F. Wagner to Congressman John J. Boylan, "Hearing Before A Subcommittee of the Committee on Military Affairs United States Senate, Seventieth Congress, First Session, on H.R. 5494,", February 12, 1929), Part II, 27.

39 Lisa Budreau, Bodies of War, 170-71.

40 Ibid.
} 
nearby battlefields to put the sacrifice in context.41 Congressmen feared that the assemblage of "large groups of grief-afflicted women" would produce dangerous mental effects. $4^{2}$ To prevent excessive "morbidness or hysteria" and protect what the U.S. government viewed as the fragile emotions of female pilgrims, the government took precautionary measures. The Army forbid elaborate ceremonies from taking place at cemeteries where women visited and reduced the somberness of the event by adopting three key features: a "prompt and accurate" trip to the grave, distribution of flowers, and a complementary photograph of the woman at the tombstone." 43 The government also planned for the physical and mental comfort of the women travelling to cemeteries in the countryside of France far away from the comforts of Paris. At several remote cemeteries, the Army constructed temporary "rest houses" decorated like an American parlor. These houses offered seating, refreshments, and restroom facilities. The purpose of the rest houses was to offer grieving women respite. Before, and after their trip to the graves, they could reflect in a comfortable space reminiscent of home. 44

Sources illustrating the French perspective of the pilgrimages show that the importance of the American pilgrimage transcended the spiritual well-being of American women. The Gold Star Pilgrimages contributed to the Franco-American exchange of memory started at the end of the Great War. Both American and French newspapers

\footnotetext{
${ }^{41}$ This is why Army officers accompanied the women, they briefed them on the fighting. Many copies of the ABMC's battlefield guidebook would have been in the possession of the groups as well.

42 John Thomas Taylor, "Hearing Before A Subcommittee of the Committee on Military Affairs United States Senate, Seventieth Congress, First Session, on H.R. 5494," February 12, 1929, Part II, 17.

43 Lisa Budrea, Bodies of War, 207. Quoting Colonel Richard Ellis, "Reporton the activities in Europe of the American Pilgrimage Gold Star Mothers and Widows, 1930," March 7, 1931, Box 8, 1922035 file, GSM Pilgrimage files, RG 92, NARA II, 19.

44 Allison Finkelstein, "The Gold Star Pilgrimage Rest Houses of 1930-1933: Ephemeral Vernacular Buildings on the Landscape of American Military Memory," (Pending Publishing). As of Spring 2014 Allison Finkelstein was an advanced doctoral candidate at the University of Maryland, College Park. Contact the author, or Allison Finkelstein, to seek more information about her scholarship.
} 
carried accounts of the pilgrimages that took place over a three-year span. The accounts from both nations relayed similar stories. French newspapers with more conservative leanings covered the pilgrimages extensively.45 L'Ouest-Éclair reported positive impressions of the "beautifully organized" American pilgrimages, and showed awe of the "unimaginable care and kindness" the U.S. government provided its women. It was clear to this paper that when it came to the memory of its fallen soldiers, Americans truthfully would "stop at no expense." 46 The same paper was also pleased to report to its French readers that the American women imparted "gratitude for the way they were received and for all the attention they were surrounded [with]." 47 In an era where many Americans seemed ungrateful to the French, it was surely refreshing to receive humble guests. The American women did not know what to expect from the French prior to their voyage, but left knowing a people "truly hospitable and friendly" to their American homeland. 48 Two years into the pilgrimages, coverage of them still found favorable space in the French papers. A 1932 article conveyed the sentiments of the American officer accompanying a group of Gold Star Mothers to the people of France. As the American mothers first stepped foot on French soil, their leader, Colonel Jordan, expressed thanks for the "beautiful expression of friendship" that the French organized. He assured the French audience that if they got a chance to speak with American mothers or widows they would find reciprocating feelings of friendship. He sincerely hoped that "one day maybe a few

\footnotetext{
45 A search for Gold Star Mothers on Bibliothèque nationale de France's digital archive brings up a multitude of articles from papers like , L'Ouest-Éclair, Le Petit Parisien, and Le Figaro spanning the entire three years. 46 "Gold Star Mothers Arrive,", L'Ouest-Éclair, June 13, 1930from online archives of Bibliothèque nationale de France.

47 “American Mothers," L'Ouest-Éclair, May 30, 1930 from online archives of Bibliothèque nationale de France. 48 Ibid.
} 
of you will visit the United States" and see the same generous courtesy." 49 American military dead and Franco-American respect for their memory created possibilities for reciprocating positive relations. Colonel Jordan's speech imparted a feeling that no matter how tense relations got between France and the United States, travelers from both nations would face little animosity abroad if they respected the memories of the dead.

A vibrant example of the diplomatic undercurrents of the Gold Start Pilgrimages was visible in speech given to American mothers recently arrived in France by General J. Pagezy, Artillery Commander of the Paris Region. In his address to American women, General Pagezy praised the heroic and ferocious American fighting man that suffered the "cruel losses" of battle.50 He acknowledged that American women deserved as much reverence from the French as American soldier dead did, because "they were your husbands, they were your sons." ${ }^{1}$ He took this admiration further by placing the sacrifice of American women on a higher pedestal than French women because their American sons crossed the Atlantic to "help a friendly nation unjustly attacked." ${ }^{2}$ When American women departed to visit "their tombs" the following day he hoped that through their deep emotion they see what how thankful France was that they left their bodies entombed in France. Speaking for France, he promised perpetual upkeep of the sacred trust, only this could prove "the eternal friendship that has always existed and will always exist between our two nations."53 A similar sentiment came from a Parisian women's group that sent American mothers home with French dirt held in a sack made of united French and

\footnotetext{
49 “Touching Franco-American Event,”, L'Ouest-Éclair, May 25, 1932from online archives of Bibliothèque nationale de France.

50 "General J. Pagezy address at Gold Star Mothers Reception," August 18, 1932, Box 2012.94, Gold Star Mothers Collection, National WWI Museum, Kansas City, Missouri.

${ }^{51}$ Ibid.

$5^{2}$ Ibid.

53 Ibid.
} 
American flags. It was the French group's hope that the French soil was just as sacred to the American mother as their own.54 Regardless of the political disagreements between France and the United States the past several years, American mothers and their dead sons could rest easy knowing that "our countries are still closely united for the defense of the common idea, for which they sacrificed their lives." 55

The Gold Star Pilgrimages were unique form of commemoration representing "a point of intersection between individual loss and national community." 56 They simultaneously brought together groups of individuals to share and reformulate memories. This in turn created a "common identity" that crafted an official narrative blurring the lines of American diversity.57 The thousands of Gold Star women participating in these pilgrimages shared a standardized experience and returned home with similar memories of the event. This is evident from the plethora of "thank you" letters that the mothers sent to the federal government upon their return to the United States. The elderly mother of a combat doctor from Charleston, WV wrote to the War Department after her trip. She spoke of her "satisfaction and pleasure" regarding her son's grave and thanked the federal government for its "generosity" and willingness to "do so much more than any of the other countries." 58 A Wisconsin mother similarly wrote to "the best government in the world," offering thanks that her son rested on the "beautiful hill sides of France.” The tender care given to her dead son brought her peace.59 A final

\footnotetext{
54 “Bienvenue Francaise Paris," Summer 1931, Box 2012.94, Gold Star Mothers Collection, National WWI Museum, Kansas City, Missouri.

55 Ibid.

${ }^{56}$ Lisa Budreau, Bodies of War, 170.

57 Ibid.

58 "Burial file of Captain Timothy Barber," Folder BA-BI, Quartermaster Records, RG 92, NARA. The box number for this file was not recorded. All burial files are cataloged alphabetically and box numbers are easy to locate. The author accessed these records during the last month that they were held at the National Archives in College Park, MD in summer 2012. They would now be located at NPRC. 59 "Burial file of Otto Arnquist," Box 147, Quartermaster Records, RG 92, NARA.
} 
example of the common memory formed by mothers during this pilgrimage comes from the mother of Dorothy Millman, a nurse from Youngstown, Ohio who died of influenza on the Western Front. Millman's mother accepted her government's pilgrimage offer to travel to the "cemetery in Europe where the remains of my daughter are interred." Like the other mothers, the "beautiful cemetery" brought to her a "peace" that words failed to express. ${ }^{60}$

These letters are not mere products of women thankful for an all-expense paid trip to visit remains. They also exhibit the devoutness of the federal government to keep the memory of a mother's, and America's, sacrifice alive in Europe. Additionally, the positive experiences of the mothers affirmed that the choice to leave their bodies in France was a good one. Americans periodically questioned French interactions with American dead since the end of the war. This ranged from the initial distrust of French motives for wanting American dead in their soil to claims of desecration after the bodies were permanently placed. The positive feedback of America's female pilgrims created a more positive image of France. The standardization of participants' reactions to the trip validated, at least partially, the program's effectiveness. Uniformity of experience showed that the federal funding for the pilgrimages successfully made American women content with their choice to relinquish remains to Uncle Sam. Their success also exposed the French to a positive aspect of American culture when the international situation seemed bleak.

6o "Burial file of Dorothy Millman," Box 1942, Quartermaster Records, RG 92, NARA. 


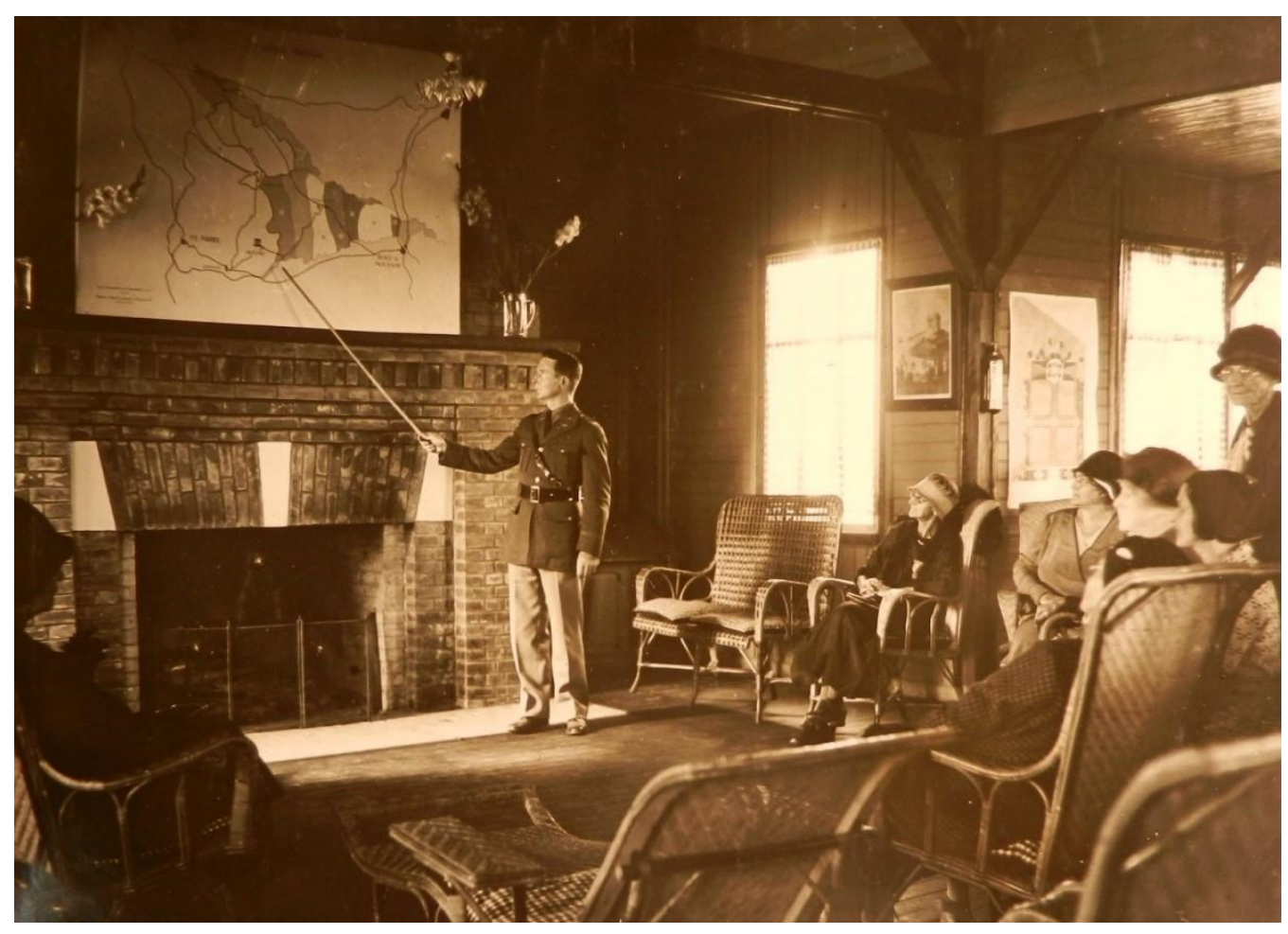

Photo 3.3: Officer giving an illustrated talk to Pilgrims at the Rest House at St. Mihiel Cemetery, undated. Source: RG 92, NARA, Records of the Office of the Quartermaster General; Photographic Albums Relating to the Pilgrimages of Gold Star Mothers and Widows, 1930-33; Box 5, Album 5 "Misc." 


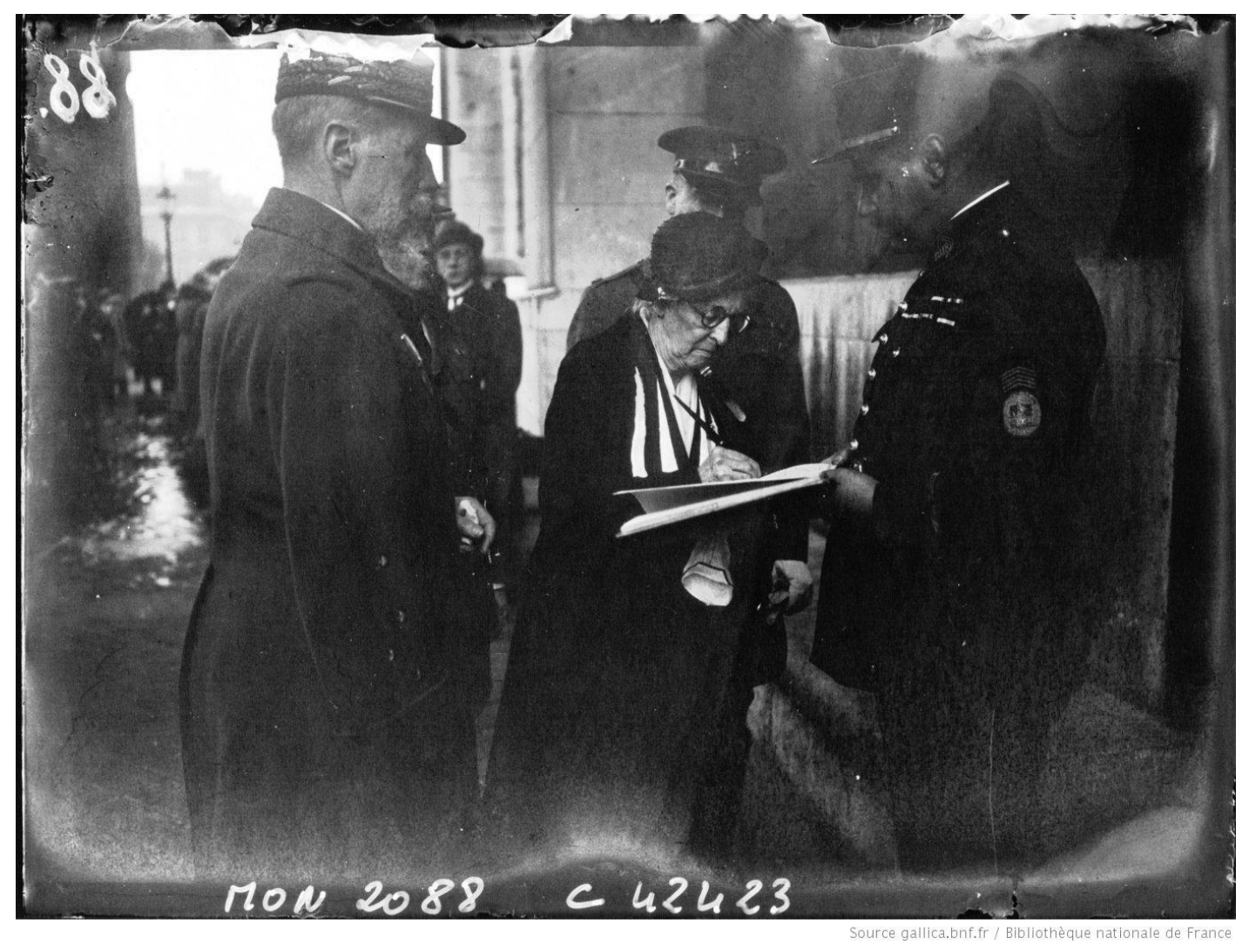

Photo 3.4: Gold Star Mother Elisabeth Anderson signing guest log at the Arch de Triomphe. Source: Bibliothèque nationale de France, département Estampes et photographie, online archives. 


\section{The Discourse of Peace}

The idea that Gold Star Pilgrimages to American graves might contribute to sustained international peace was reflective of the transitioning discourse of the dead through the 1930s. From the end of the Great War, through the 1920s, much of the rhetoric of memory diplomacy possessed visible hostility towards communist revolution. It also offered a means to respond against anti-Americanism. American leaders used the dead to make powerful statements about growing anti-Americanism in France and increased left-wing radicalism throughout the world. Through all of the aggressive uses of American dead, hopes of peace remained prevalent theme. Starting in the 1930s, peace increasingly became the focus of messages assigned to American dead in foreign soil.

The heightened anti-Americanism in France throughout the 1920s diminished some by the 1930s, but the French Third Republic faced instability. From 1932 to 1940, a dozen prime ministers led the French parliament. This is not the place to discuss how each of these leaders engaged with the memories of American military remains. The following section focuses on the period of William C. Bullitt's ambassadorship to France and explains the diplomatic uses of memory during this period. Bullitt arrived to France in 1936, three years after the pilgrimages ended. His tenure is a good analytical point of entry for a study of memory diplomacy because it coincided with the completion of the ABMC's major commemorative projects and the German occupation of France. When William C. Bullitt took over as America's Ambassador to France in 1936, he brought to the position intimate knowledge of communism, and a strong distaste for the ideology. Bullitt formed these ideas from his previous diplomatic assignment as America's first 
ambassador to the Soviet Union. Still, most of his use of American memory focused on how the U.S. and France could use their memories of shared sacrifice to maintain harmonious Franco-American relations, not simply to show hatred towards communism.

As Bullitt's service in France began, André Léon Blum served as France's Prime Minister. Blum's tenure highlighted deep political fractures in France. He represented the moderate left branch of the Socialist Party and united parties on the left and centre into a Popular Front that opposed right-wing fascists groups gaining momentum with Hitler's rise. This fragile coalition was short lived as each component differed on its ultimate goal. Communists cared about progressing revolutionary goals, and the leftist radicals could not agree with the monetary and social reforms supported by Blum's Socialists. Despite the brevity of France's Popular Front, its existence stemmed from the violent coalition of powerful right wing groups in France associated with fascist and royalist tendencies. Although fractured, the conservative right wing groups of political clubs, university students, and disillusioned veterans successfully mobilized throughout the 1930 s to disrupt public meetings and riot against the left. Their most effective violent outburst came on January 27, 1934, when radical socialist Édouard Daladier was elected as Prime Minister. Fascists leagues responded to the election with a violent riot near the French National Assembly on February 6, 1934. The rioting spread throughout France and turned into a battle between the left and right. At the end of the riot over a dozen protestors died with thousands more wounded. Daladier stepped down the day after the riot to be replaced by a conservative. The effectiveness of the right, and the bloodshed they caused, remained in the political consciousness of French politicians for much of the twentieth century. 
It was in this heated environment that Ambassador Bullitt engaged diplomatically with the French. While anti-Americanism waned, an overthrow of America's greatest democratic partner from within, or from outside, seemed highly possible. ${ }^{61}$ Bullitt's correspondence in his early tenure as ambassador indicated that he feared outward influences on France's stability more so than domestic riots. Bullitt reminded President Roosevelt in a cablegram that although reports of riots come frequently from France, it must be remembered that "they are very French riots, carried out in the most pleasant and almost theatrical spirit and are not to be taken seriouslyat least not yet." He added that "people forget how politely the French can riot."62 Major anti-American demonstrations demanded attention from American ambassadors in the earlier interwar period. Bullitt's dismissal of French domestic protest showed that more of his attention in the mid-thirties went towards events outside of France. This outward focus coincided with a new direction in the utility of America's WWI memory abroad. Instead of using American memory of World War I to effect change within France, it was broadened to address bigger international concerns. The official dedication of the ABMC's World War I cemeteries in 1937 offered American and French leaders a platform to articulate broader diplomatic goals. International problems overshadowed domestic issues for leaders from France and the United States when they stood on the most spotlighted stages of memory since the Great War's end.

\footnotetext{
${ }^{61}$ An excellent account of the French political situation can be found in Orville H. Bullitt ed., Correspondence Between Franklin D. Roosevelt and William C. Bullitt: For the President, Personal and Secret (Boston: Houghton Mifflin Company, 1972), 170-171.

62 "Bullitt to Franklin Roosevelt," October 4, 1936 in Orville H. Bullitt ed., Correspondence Between Franklin D. Roosevelt and William C. Bullitt: For the President, Personal and Secret (Boston: Houghton Mifflin Company, 1972), 174-175.
} 
Aggressive actions of the fascist governments that once drew support from the United States, brought a shifted American war memory in the late 1930s. Gold Star Mothers spread messages of the pain war caused on their tours of Europe in the early 1930s. Perhaps the most prominent example of the peaceful turn in the discourse of the dead came on August 1, 1937, years after the female pilgrimages ended. On this day, a very public display of American World War I memory and cultural bonds between France and the United States took place when the ABMC dedicated the crown jewel of its WWI memorials, a domineering Doric column atop Montfaucon. This large commemorative shaft was visible for miles and oriented everyone in the area to where Americans sacrificed on the Meuse-Argonne battlefield. Mountfaucon represented one of America's most dramatic battles in the Great War and stood just miles away from the largest congregation of American military remains in the small village of Romagne-sousMontfaucon. The dedication in mid-summer was an impressive event. Its list of speakers was attention grabbing: General Pershing, General Petain, Ambassador Bullitt, French President M. Albert Lebrun, and President Franklin Roosevelt (via radio). The American government chose this site to make its grandest display of American sacrifice for a peaceful world order. No other American site of memory possessed the power that fourteen-thousand remains offered. The ceremony held was elaborate. It included nearly two hours of parade, speeches, patriotic song, and prayer. This was also the most public of all American dedications. American radio broadcasted the entire event live throughout America and France with commentators guiding them through the proceedings as if it were a sporting event. This was a chance for leaders in both France and the United States to publicly engage the discourse of sacrifice and tell both of their publics how this discourse offered insight on dealing with new international crisis. 
There had been plenty of European tension throughout the interwar years, but this dedication came during a period of great uncertainty. The location of the dedication was surely bittersweet for the speakers and the audience. Germany reoccupied the Rhineland, only a short distance east, just a year before, signifying renewed militarism and a clear break from the Treaty of Versailles. Nazis in Germany represented a force of chaos to the United States nearly equivalent to Russian communists. ${ }^{63}$ Mussolini no longer looked like the good dictator that Americans saw following his assumption of power in the 1920s. He openly supported a Berlin-Rome coalition with this dangerous party. In a speech given in Berlin weeks after Montfaucon, Mussolini spoke of "Fascism and Nazism" as "two manifestations of parallel historical situations." 64 Both nations shared the "same conceptions of life and history" and believed "in violence as a force determining the life of peoples." 65 Commitment to violence had already been proven. At the time of the Montfaucon dedication Italy had formally annexed Ethiopia. It would officially join the Anti-Comintern alliance in months. In other parts of the world, Japan was waging a ruthless war against the Chinese, and Joseph Stalin had just began his most brutal phase of purges.

Woodrow Wilson's use of war remains as justification for collective security to avoid war had made the first of many full revolutions in the twentieth century. At Montfaucon, leaders of France and the United States made their most direct appeal for citizens of the world to understand that they sacrificed in the Great War so peace might

\footnotetext{
63 Costligliola, Awkward Dominion, 235.

64 Benito Mussolini, “The Berlin Speech," September 29, 1937, from Roger Griffin ed., Fascism (New York: Oxford University Press, 1995), 79. 65 Ibid.
} 
last. In all of the speeches delivered that day, there was hope that that American remains and soldiers' memories of war could prevent the outbreak of a new conflict. ${ }^{66}$ After several prayers from religious figures, the stage at Montfaucon went to Ambassador Bullitt. He began the ceremony calling upon the audience of hundreds of French and Americans to recall the friendship between the two nations stretching from Yorktown to the Meuse-Argonne. In an era of political and social revolutions, it was important to focus on memories of the democratic revolutions in both nation's past. Bullitt noted that the French soldiers who died in the American Revolution and the Americans who died in the Great War fell as victors. Their victory meant nothing without peace, however. The fight that Franco-American soldiers faced in this age was for "Peace." ${ }^{7}$ Bullitt's comments did not dwell on the internal disruption in the French political system or respond to anti-Americanism. They instead addressed calming international tensions. The rhetoric of violence to regenerate national power prevalent in Nazi and Fascist rhetoric was absent here. Bullitt saw in France and the United States an alliance similar to that of Italy and Germany, yet France and America "marched together under the flag of peace," not war. ${ }^{68}$ Months before, Bullitt delivered a similar Memorial Day dedicatory address at the new chapel in the Suresnes American cemetery as French airplanes unloaded a rain of flowers on the American graves. 69 Bullitt's

\footnotetext{
66 The broadcast of the event is available at NARA II on the sound archive floor in RG 117. None of the French speeches that American's heard on the broadcast were translated into English. The ABMC did publish translated transcriptions of all their monument dedications, but the circulation of these publications is currently unknown.

67 "Address by Bullitt," Dedication of the American Meuse-Argonne War Memorial, Montfaucon, Sunday, August 1, 1937 (Washington, DC: ABMC, 1937), Box 165, Entry 470, ABMC Records, RG 117, NARA.

68 Ibid.

69 Ibid.
} 
message of peace set the tone for what was to come. More famous speakers followed Bullitt and advanced his themes.

The National Commander of the American Legion, Harry Colmery, told his enormous audience that the thousands of Americans "who lie pillowed in glory... sleeping tenderly secure in the embrace of France" remind the world that the "blessings of peace are more fruitful and lasting than the spoils of war."7o The most explicit antiwar speech of the day came from General of the Armies, and ABMC Chairman, John Pershing. Pershing used the public occasion to make a political statement regarding the current turmoil in Europe. He noted that the events commemorated ought to bring about hatred for war. He urged the international press to resist printing "sensational news that inflamed international antagonisms" and feared that unless a cure to the international "madness" was found, western civilization would fall. ${ }^{11} \mathrm{He}$ was sad that his "conflict left many questions still unsettled" and that "hatred and suspicions still exist while armaments continue to grow."72 Pershing had pride for the Montfaucon memorial his ABMC erected, but felt the best memorial for the "silent millions who lie in Europe's war cemeteries" should be international cooperation and open dialogue among nations.73 Evoking the memory of soldier dead, Pershing assured his audience that if the dead could speak, they would "with one voice join us in offering an ardent prayer to God that there may never be another world war."74 Montfaucon marked the

\footnotetext{
70 "Address by Harry Colmery," Dedication of the American Meuse-Argonne War Memorial, Montfaucon, Sunday, August 1, 1937 (Washington, DC: ABMC, 1937), Box 165, Entry 470, ABMC Records, RG 117, NARA..

71 "Address of General Pershing," Dedication of the American Meuse-Argonne War Memorial, Montfaucon, Sunday, August 1, 1937 (Washington, DC: ABMC, 1937), Box 165, Entry 470, ABMC Records, RG 117, NARA.

72 Ibid.

73 Ibid.

74 Ibid.
} 
culmination of Pershing work as the caretaker of American World War I memory, and in this, his most heard speech as the ABMC's leader, the dead soldiers of his A.E.F. remained entirely in focus. Pershing resided in France for much of the interwar period and saw the ebb-and-flow of anti-Americanism and left-wing protest. His words as the ABMC spokesman at the end of the interwar era provided insight into his perception of the utility of American commemoration. Pershing's ABMC sites were certainly meant for mourning. He personally greeted grieving pilgrims, accompanied them to ABMC sites, and frequently participated in memorial ceremonies throughout the interwar. With the prospect of new conflict looming, Pershing's words revealed that he also viewed his dead soldiers in France as tokens of peace. He lobbied for their bodies to remain behind and hoped that their presence on European soil might contribute to the "hopefulness of a future" in which all people "detest war."75

President Roosevelt similarly turned to soldier dead as reason to avoid future war when he addressed the audience live via radio broadcast. He reminded spectators standing on the massive battlefield that American military men "contributed their lives and lie buried on this and other battlefields" and that they died "brothers in arms with Frenchmen" as martyrs for the "ideals of democracy." The essence of FDR's speech was that both French and American soldiers died for peace, and through their deaths the two nations' "cultures were brought into closer communion" than ever. ${ }^{76}$ French President M. Albert Lebrun provided a similar message of peace. Lebrun spoke for all of France, urging all to remember the remains as symbols assuring "the future of Civilization, and

\footnotetext{
75 Ibid.

76 "Radio Address by President Franklin D. Roosevelt Dedication of the American Meuse-Argonne War Memorial, Montfaucon, Sunday, August 1, 1937 (Washington, DC: ABMC, 1937), Box 165, Entry 470, ABMC Records, RG 117, NARA.
} 
guides to the world for a blessed path of peace, despite the current disturbances."

Because of the international "disturbances everywhere," Lebrun felt that the "two great Democracies should remain united" to assure international stability. ${ }^{77}$ American sites of memory served as meeting places for the dead in Lebrun's imagination. While standing at Montfaucon he expressed the belief that such places acted as "points of assembly for the spirits of the victims of war." 78 American spirits, along with French and British cohorts met on memorial grounds in the "majesty of peaceful summer nights" in the gentle caress of France. 79 Visitation to sites of memory allowed the living a chance to interact with the dead on a spiritual level and learn how to avoid their "cruel past." 80

The radio broadcast of this ceremony meant that a larger audience participated in this type of commemorative ceremony than ever before. The Meuse-Argonne dedication was the first of its kind to take place in the era of mass communication. Radio allowed French listeners to hear the words of President Roosevelt "brought through the ocean" to invoke thoughts of "the great American people." 11 Over the course of the 1930s, the United States turned to the new technology of radio to "broadcast in the service of peace" and combat Nazi radio programs that purveyed their own interpretation of current events to international audiences. ${ }^{82}$ Radio allowed the governments of the United States and France to reach a much larger audience with the Montfaucon dedication than ever possible before. Montfaucon was likely the most listened to

\footnotetext{
77 "Address of French President M. Albert Lebrun," Dedication of the American Meuse-Argonne War Memorial, Montfaucon, Sunday, August 1, 1937 (Washington, DC: ABMC, 1937), Box 165, Entry 470, ABMC Records, RG 117, NARA.

${ }^{78}$ Ibid.

79 Ibid.

80 Ibid.

81 At Montfaucon," L'Humanité, August 2, 1937from online archives of Bibliothèque nationale de France.

${ }^{82}$ Hart, Empire of Ideas, 20.
} 
example of a memory exchange between France and the United States up to that point in the twentieth century. The broadcast also opened the gates of cultural transfer. American and French listeners heard speakers talking in their native tongue and had no translation available. Although a language barrier existed, the raw emotion of the speakers still came through. A reigning feeling of genuineness prevailed. Listeners heard the event just as the live audience did. They heard French and American patriotic songs, and vividly pictured the event through detailed commentary by broadcasters. The American soldiers who died in the Meuse nearly two decades were gone, but political leaders kept their memory alive, and made them into public symbols of peace. President Roosevelt reported to Ambassador Bullitt days after the dedication that "the ceremonies at Montfaucon came through splendidly and your voice and what you said were excellent. I am glad to know, too, that my voice got through to all of you who were at the field." 83 Participants were pleased that a message of peace, along with the commitment of a Franco-American alliance, was disseminated to such a large audience.

It was unknown if the message of peace at Montfaucon would be fulfilled. France's daily socialist newspaper, L'Humanité reported to their readers the promise speakers offered at Montfaucon that "peace will be saved by the friendly relations existing between the long three great democracies of the world." 84 In the following years, France and America continued their attempts to spread messages of peace through the memories of the dead. To maximize the audience, America even moved its traditional Memorial Day ceremonies in France from Monday to a weekend, "in

83 "FDR to Bullitt," August 5, 1937, from Bullitt ed., Correspondence Between Franklin D. Roosevelt and William C. Bullitt, 226-227.

84 At Montfaucon," L'Humanité, August 2, 1937from online archives of Bibliothèque nationale de France. 
expectation that more French people will be able to attend than on a working day in France." This was likely approved by the, returned to power, Socialist Prime Minister Édouard Daladier, who represented the French workers. ${ }^{85}$ Efforts to include French workers in American memory indicated a large shift from the anti-Bolshevisk messages of Myron Herrick's 1920s Memorial Days. Leaders in the American Legion also took steps to rehabilitate the image of American veterans in Paris during the period. An ABMC staffer reported to General Pershing in 1936 that steps had been taken to stress "more milder forms of indoor sport and entertainment" among American veterans. Furthermore, their leaders took steps to "hold down the heavy drinking and ribald" elements of their meetings in Paris. ${ }^{86}$ The sometimes brash and aggressive nature of American World War I memory tamed considerably in France during the 1930s. This was a direct response to instability around the world. The 1927 Legionnaires' convention in Paris was not a public relations disaster, but the tone of American memory abroad changed considerably after its conclusion. Economic depression and political revolution did not put the Allies in a position to stoke the fires and project an aggressive image of themselves to others. The more reserved American memory of its soldier dead reflected in Gold Star Mother Pilgrimages and 1930s monuments dedications reflected the shifting memory of American dead in Western European soil.

\footnotetext{
85 "Memorial Services Scheduled at French Cemeteries Today," The New York Times, May 29, 1938 in Proquest Historical Newspapers.

86 Mark Boatner, Jr. to John Pershing, January 20, 1936, Box 7, Pershing Correspondence File, ABMC Records, RG 117, NARA.
} 


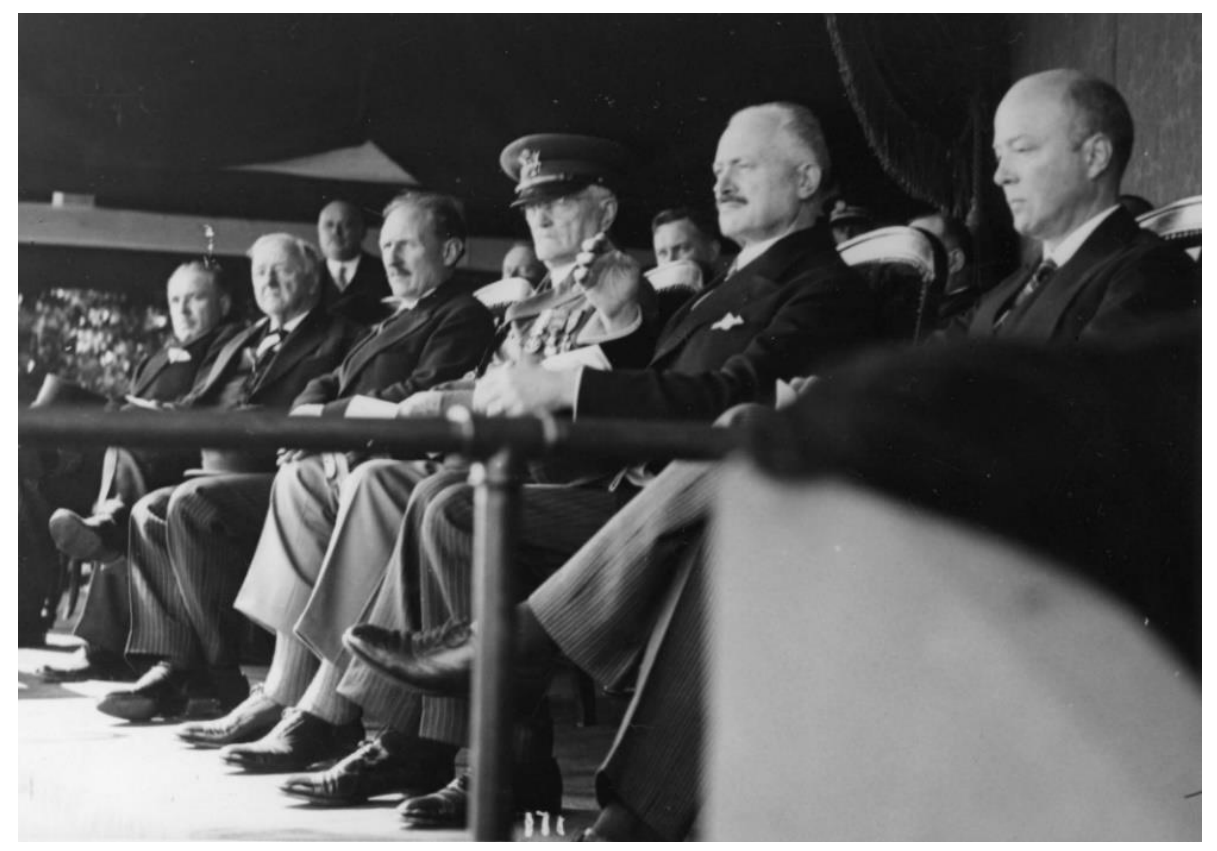

Photo 3.5: Speakers on podium at Montfaucon Dedication, August 1, 1937. Source: ABMC Archives, Arlington, VA. Pershing is the elderly uniformed man in the center, to his left is French President Lebrun, and Ambassador Bullitt.

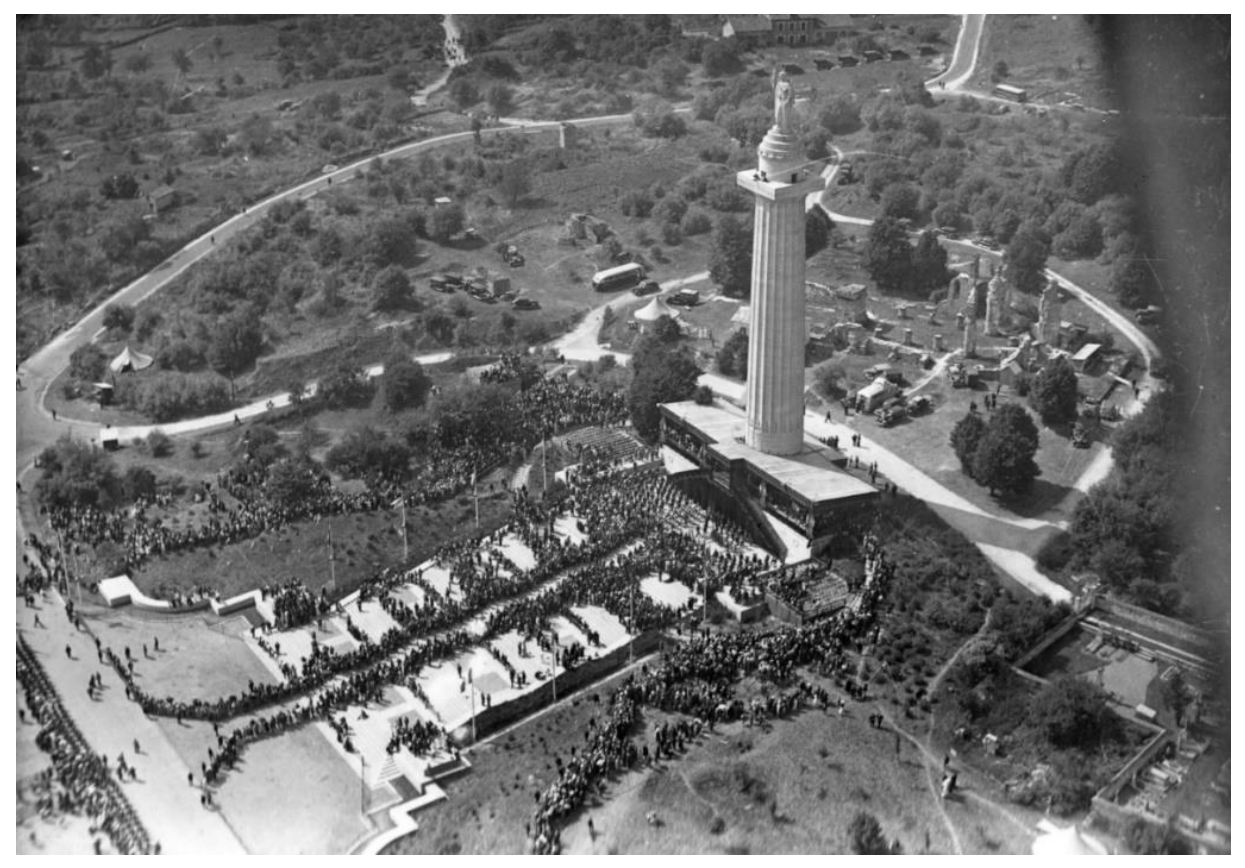

Photo 3.6.: Aerial view of Montfaucon Dedication, August 1, 1937. Source: ABMC Archives, Arlington, $V A$. 


\section{American Dead in Red Soil}

Thus far, this chapter has focused on the peaceful message assigned to American military dead in France through the 1930s. It is now worthwhile to shift geographic focus to see how the United States government viewed its soldier dead in a European country perceived as unfriendly. While American soldier dead in France became symbols of peace and friendship, soldier dead in Soviet Russia were a liability in need of rapid removal. American soldier dead in France worked to bolster good relations because they represented common sacrifice. In the Soviet Union, the American dead from the same war stood as a reminder to Russians of invasion. The expedition to remove American remains from Russia represented one of the first diplomatic interactions between the United States and the Soviet Union. Repatriation of negative memories also helped keep peaceable relations with the Soviets while the international situation elsewhere deteriorated.

When Ambassador Myron Herrick delivered his attack on Russian communism at Suresnes in May 1927 by invoking the memory of American dead at Suresnes, hundreds of American remains of the same war rested in the same cancerous Soviet soil he reprimanded. Herrick's opening declaration to his Parisian audience that "wherever an American soldier lies buried in any part of the world his compatriots today lovingly gather to honor his memory" was simply not true. 87 Nor was his statement that "we have no thought of attacking the Soviet regime in Russia; what it does on its own 'reservation' is

87 "Urges World Fight Against Red Peril," The New York Times, May 31, 1927, in Proquest Historical Newspapers. 
its own affair."88 American soldiers had already attacked Soviets between the summers of 1918 and 1919 around the Dvina River in Northern Russia. The "insidious menace" and saddest "moral debacle known to history" that he called Russia, did not conduct memorial services in 1927 to the thousands of American soldiers who took part in a small invasion of their soil. 89

President Wilson sent soldiers from the American $85^{\text {th }}$ Division, primarily natives of Michigan, into Russia to join an expeditionary force of British and French soldiers in the final year of the Great War. Their mission was to ensure that allied weapons stockpiled in Archangelsk, a White Sea port, did not fall into the hands of the revolutionary Bolsheviks. The recovery mission escalated into an offensive against Bolsheviks quickly. For approximately a year after the Great War ended, American troops fought in the subarctic climate. This "Polar Bear Expedition" grew unpopular in the United States. War ended on the Western Front and Wilson participated in the treaty negotiations while speaking of world peace. All the while, the war continued for American soldiers in Russia. Morale dropped within the ranks of the Polar Bears, and families called for their return home. Approximately 230 Americans died in this fighting, only onehundred of these remains departed with living in 1919.90 Reports of the American withdraw from Russia revealed a chaotic scene with American and British soldiers frantically exhuming corpses as their hour of departure neared. ${ }^{91}$ The remaining corpses laid in frozen soil that their home country would not give official diplomatic recognition

\footnotetext{
88 Ibid.

89 Ibid.

90 Daniel Gibbs to Quartermaster General, “Bodies recovered from Russia,” January 3, 1935, Box 181, Other Records Relating to Cemeteries and Memorials, File 293.8, ABMC Records, RG 117, NARA, p. 1. ${ }^{11}$ Connor to Adjutant General, "S.O.S. Number 2359," October 23, 1919, Box 565, File 293.8, Central Decimal File 1917-25, Adjutant General Records, RG 407, NARA.
} 
to until 1933. American efforts to recover these remains from communist Russia foreshadowed the future relationship of the United States with the Soviet Union and the direction that the diplomatic nature of U.S. memory would move in the Cold War. A detailed American account of the recovery in 1934 also indicated cultural differences between Americans and Russians regarding care of dead soldiers of memories of past conflict.

Myron Herrick saw communists in Paris as Russian agents secretly sent to spread "germs of a loathsome malady."92 Distrust between Russia and the United States and fear of infiltration remained constant themes throughout the twentieth century. Lack of diplomatic relations between the two countries through most of the interwar years even made tasks like body recovery espionage missions. America first made an attempt locate its soldier dead from unfriendly communist soil in 1929. The Russian government did not allow American military to be a part of this. In lieu of the military, they allowed a contingent of members from the Veterans of Foreign Wars and Michigan's Polar Bear Association into Archangelsk. Within this group, the American Graves Registration Service imbedded "an army officer" and "a group of civilian employees of the U.S. Army masquerading" as VFW members. 93 This specialized subgroup did the serious recovery work.94 The infiltration mission proved successful. Before winter weather made the task of recovery impossible, they saved all but thirty-nine American remains from communist soil.95 The final attempt to recover these remains came after President Franklin Roosevelt gave diplomatic recognition to the Soviet Union in 1933.

\footnotetext{
92 "Urges World Fight Against Red Peril," The New York Times, May 31, 1927.

93 Daniel Gibbs to Quartermaster General, "Bodies recovered from Russia," January 3, 1935, Box 181, Other Records Relating to Cemeteries and Memorials, File 293.8, ABMC Records, RG 117, NARA, p. 1. 94 Ibid., 1.

95 Ibid.
} 
Within the first year of recognizing the Soviet Union as a legitimate government, the United States asked Moscow for permission to remove the remainder of its bodies from the Polar Bear Expedition. The Soviets granted permission, Congress allocated funds, and Russia's Intourist Company provided a contract to escort the American expedition. Daniel Gibbs, an officer in the Grave Registration Service, led the team of Americans on the ground in Russia. Throughout the expedition, he kept a daily record and presented a detailed report to the Quartermaster Department at the conclusion of the mission. Washington undertook the mission not only to satisfy the American need to recover its remains, but also to help remedy a "diplomatic problem of considerable magnitude.”96 Although the United States and U.S.S.R. never officially entered a state of war with one another, the American remains in Soviet soil had been the aggressors. They occupied the country for over a year" destroying "crops, homes, and driving people away from towns."97 Both sides essentially fought a "guerrilla war" and a "great deal of ill feeling" lingered in the Russian countryside 98 The bodies of British and French soldiers would remain in Northern Russia, but America's would not. Removal of American bodies might erase the memory of American aggression from the Russian landscape. In France, American military bodies represented friendship and shared sacrifice. In Russia, remains from the same army represented invaders whose actions killed civilians.

Gibbs anticipated Russian animosity towards his team as the prepared to depart for Russia in 1934. His report of the recovery mission revealed a clash of two very different cultures and America's perception of Russian communism in the interwar. Gibbs's account of the expedition read much like an anthropologic journal. He offered

\footnotetext{
${ }_{96}^{6}$ Ibid., 2.

97 Ibid.

98 Ibid.
} 
numerous accounts of the Russian people throughout his report. American diplomats viewed communism in scientific terms. It was akin to an illness, a poison, or a cancer. If left unchecked, communist ideology could infect healthy democratic capitalist society world-wide. 99 As one of the most thriving democratic capitalist societies, American leaders often assumed the role as the physician most capable of removing the malady. Gibbs was in Russia to save American soldier dead from obscurity and remove them from a diseased host. In his capacity as representative of the American government, his recovery mission forced the two cultures to engage with one another, informally, in this early phase of open diplomacy.

Gibbs went into Russia with a detailed report of the previous American recovery mission and a member of the first expedition. The North Russian landscape was still foreign to Gibbs, however. He and his team needed communist Russians to aid him in the recovery mission. Russian laborers travelled with Gibbs and Russian peasants offered their memories of the Polar Bear's actions and burials. Russians helped Gibbs's team, but also hindered them. Frequently his report indicated that searches for American graves stopped early when peasants became angered that their own burial grounds were disturbed in the process. Throughout Gibbs's report, he distinguished between the Russian people and communism. They often did not seem the same to him, and when there was an overlap, he saw the Russian people of victims of a broken system. They had no usable infrastructure, no potable drinking water, no personal assets, and corrupt local bureaucracy. ${ }^{100}$ He saw Russians as patriots who loved their country much more than

\footnotetext{
99 “Urges World Fight Against Red Peril," The New York Times, May 31, 1927 in Proquest Historical Newspapers.

${ }^{100}$ Daniel Gibbs to Quartermaster General, "Bodies recovered from Russia," January 3, 1935, Box 181, Other Records Relating to Cemeteries and Memorials, File 293.8, ABMC Records, RG 117, NARA, pp. 5-7.
} 
the "abstract principles of communism." 101 They were "honest" and as his primary labor force "willing [and] friendly, but not overly quick to grasp ideas and not fast workers."102 The Russian peasants often helped Gibbs locate possible American graves. They seemed to respect the American mission, but showed confusion about the great lengths taken to recover a few dead. The nearly two decades that had elapsed since the American remains had been buried meant that that American team often dug up many nonAmerican remains before finding one of the thirty-nine bodies they sought. The Russians had little patience when Gibbs and his team entered into Russian cemeteries and mistakenly dug up Russian bodies. ${ }^{103}$ Often their visible discomfort forced him to cease digging. At one point, American intelligence led Gibbs to a mass grave where an American soldier possibly rested. Gibbs completely abandoned the search when Russian officials told him that it primarily contained the bodies of "women and children killed by an Allied bomb."104 As leader of the expedition, Gibbs determined it was in the best interest of America's reputation to not disturb such a sacred spot. It was not feasible for the American mission to dig up the graves of Russian civilians killed by their artillery to find the grave of one doughboy. Gibbs respect for Russian memory signified willingness to improve U.S.-Soviet relations on the personal level. While small, gestures like this surely helped improve Russian perceptions of the United States. Another instance of positive relations built during the trip was a rudimentary celebration of July $4^{\text {th }}$ in which Russians and Americans took time from their work to celebrate, shared canned goods, and drink whisky. ${ }^{105}$ Removal of American remains represented a diplomatic mission much

\footnotetext{
${ }^{101}$ Ibid., 2.

${ }^{102}$ Ibid., 2-6.

103 Ibid., 8, 10.

104 Ibid., 18.

105 Ibid., 8.
} 
different than those in Western Europe, it still opened positive cultural exchange unavailable otherwise. The American team located 17-19 of their bodies during the trip. ${ }^{106}$ Gibbs ultimately attributed this success to the kindness and assistance of the Russian people. ${ }^{107}$

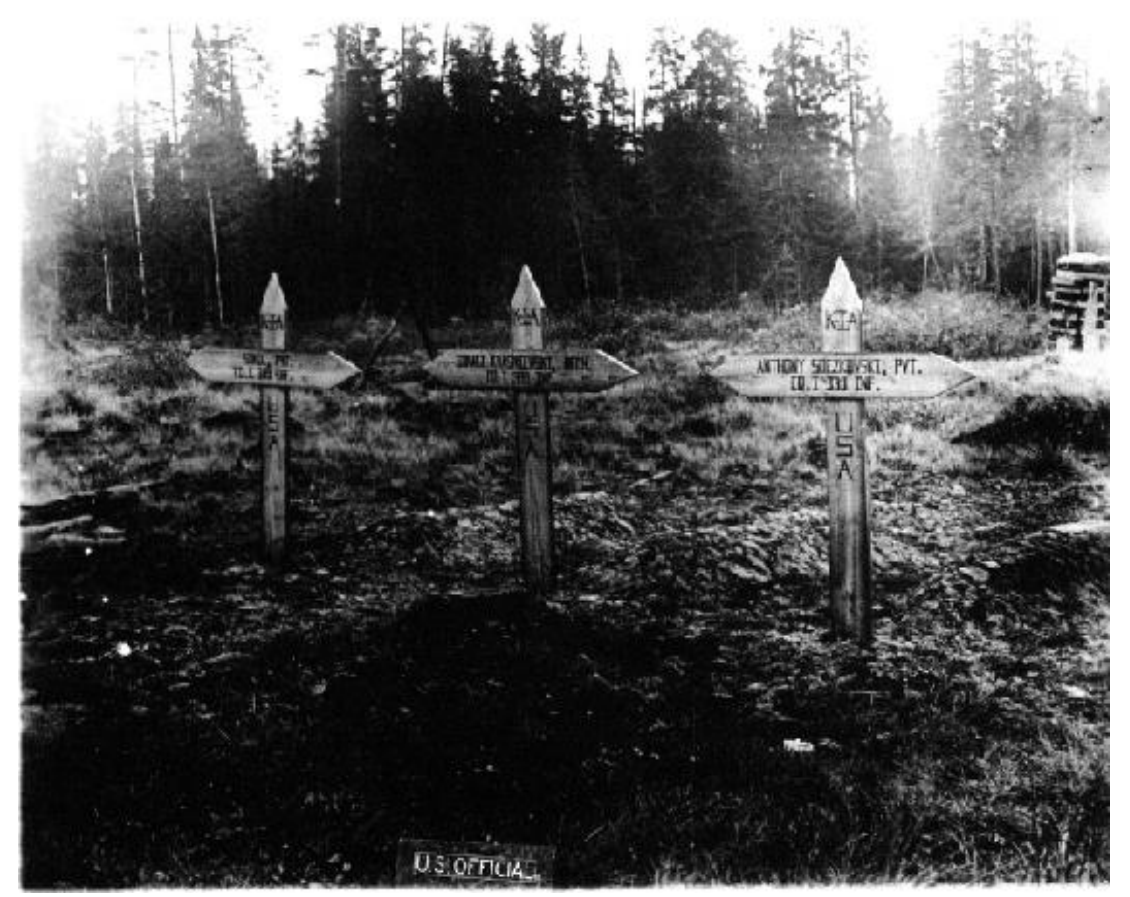

Photo 3.7: U.S. Army Signal Corps, Print No. 32053, "Graves of first thee American Soldiers Killed in Action on the Northern Russian Front," September 16, 1918 (L-R Ignacy Kwasniewski, Antony Soczkoski, and Phillip Sokol. Source: University of Michigan Polar Bear Expedition Collection,

http://quod.lib.umich.edu/p/polar/921010.0002.012/1?page=root;size=100;view=image.

Gibbs saw admirable qualities from Russians during his exhumation mission, but he cited much disrespect for their communist government. Much of this was directed toward the disregard communists had for treatment of American remains. One of the most visible examples Gibbs offered of communist indifference towards American dead

${ }^{106}$ Ibid., 20-22. The number that Gibbs gives fluctuates from 12, 17, and 19.

107 Ibid. 22. 
was the way they treated them before burial. Gibbs found that all of the American bodies buried by the Bolsheviks has been "skinned like rabbits, only leaving underclothes and damaged equipment." 108 Once Gibb's had collected the American remains and placed them in individually sealed coffins, it was up to the Soviet escort agency to prepare them for shipping. Gibbs was mortified when he reached the sea port to find that government officials had "shipped the bodies as baggage" and "piled them up like freight." $109 \mathrm{He}$ determined that the Soviet contractor treated the corpses disrespectfully as freight and not bodies as a "cheap trick to save money" in shipping costs. ${ }^{110}$ Soviets did not trust Gibbs and his team either. They allowed no photography of American burial sites, or sites for possible future searches unless a special Soviet official was present. ${ }^{111}$ Before the American bodies left Russia for America or burial in ABMC sites in Europe, Soviet law required the opening of the soldered caskets for final inspection. This was done to ensure that Gibbs had not tried to smuggle out "works of art, or valuable furs" along with American remains. ${ }^{112}$ Gibbs was thankful that the customs agents abandoned the search after blowtorching open only two caskets and finding nothing but decomposing corpses.

This detailed account revealed much about the differing ways memory worked diplomatically between the United States and other nations. America's interment decisions indicated its desire for continuance of positive relations. Allowing the burial of American military dead in foreign soil was a token of friendship, as was another country's granting of land for burial plots. This phenomenon was uniquely American. For example, Great Britain tended to leave its soldier dead where they fell; friend or enemy. British

\footnotetext{
${ }^{108}$ Ibid., 7.

109 Ibid., 19.

110 Ibid.

${ }^{111}$ Ibid.

112 Ibid., 20.
} 
soldiers rested in both Germany and the remote Russian arctic-and all over the world for that matter. It was important for the American government to have its dead interred in the soil of partners, not in the soil of perceived enemies. The decision makers in American commemoration felt that Americans would only entrust their dead to their government if they placed them in the soil of a friendly nation that they could easily access. This is perhaps a flawed policy. The symbolic importance Americans placed on entrusting their military dead to a nation was paramount. Allowing American soldiers to rest in Russia or Germany might have signified faith in the future. Consider the diplomatic power during the Cold War of an American president standing over American graves in Russia and acknowledging the faults of the Polar Bear Expedition and seeing in American graves as reason to improve relations. This was not the case, however. Locations of America's military cemeteries indicate what it takes to be a friend to the United States. The list includes: a shared history, commitment to individual liberty, a capitalist economic system, Judeo-Christianity, and to a certain extent-whiteness. During the interwar years, America could not get its bodies out of Russia quickly enough.

It is possible that removing American bodies from enemy soil is indicative of attempts to forget animosity. Not having American bodies and monuments on the memory landscape makes forgetting easier. Archangelsk is virtually unknown to Americans. Would this be the case if the American government commemorated 230 bodies there? Likely not, because the value that American culture places on care for its military dead requires rigorous upkeep and annual ceremonies. Even the wartime alliance of the Soviet Union and the United States failed to make Soviet soil a viable depository of American soldier dead. It is arguable that the alliance crumbled so quickly after World War II that there was no time to erect an American cemetery in Russia. 
Thomas North, the ABMC's administrative secretary during the early Cold War, indicated that the ABMC did "hope" to put an American cemetery on the soil of their wartime ally. However, the "churlish attitude of the Soviet officials discouraged" these wishes. ${ }^{113}$ Stories of Soviets ordering Germans to "till cemeteries" to address the food crisis in the Soviet zone of Germany highlighted the unsurmountable cultural differences between the Soviet Union and United States regarding war dead. ${ }^{114}$ Soviet soil was unfit for American dead from either World War, whether they fell as enemies or allies.

The removal of American Polar Bear remains from unfriendly Russian soil provided some groups in the United States incentive to lobby the American Battle Monuments Commission for more repatriations. If the federal government had the power to allow repatriation of remains from the Polar Bear Expedition, surely it could approve the return of dead from other units. One such request came to the ABMC in 1934 from the Veteran's Association of the $42^{\text {nd }}$ Division and Gold Star Father, Edward Bird. ${ }^{115}$ This was a misguided request from the $42^{\text {nd }}$ Division because the remains coming out of Russia did not rest in ABMC cemeteries. Still, the correspondence surrounding this request demonstrated the type of responsibility the ABMC felt towards the remains it cared for. It also showed that American remains in Russia represented something entirely different to the United States than remains in friendly Europe. Letters to the ABMC also indicated the accountability that the general public felt that the ABMC needed to display when caring for war dead. It is evident through this

113 Thomas North, One Soldier's Job (Washington, DC: Unpublished, Undated), II-6.

114 Delbert Clark, "Germans Ordered to Till Cemeteries," The New York Times, December 19, 1946, in Proquest Historical Newspapers.

115 Xenophon H. Price to Chaplain Earl L. Holliday, October 15, 1934, Box 181, Removal and Reinternments Folder, ABMC Records, RG 117, NARA and Rainbow Division Veterans to General Pershing, May 14, 1935, Box 181, Removal and Reinternments Folder, ABMC Records, RG 117, NARA. 
correspondence that the ABMC viewed itself as the official voice of American military dead abroad, and their protector. Understanding of the paternal-like role the ABMC saw itself fulfilling for remains abroad helps explain the type of message cemeteries projected onto foreign audiences.

The repatriation request that the $42^{\text {nd }}$ "Rainbow" Division sent to the ABMC in the mid-thirties regarded the remains of Private Dyer Bird, a native of Marion, Ohio, and the first man killed from the division during the Great War. ${ }^{116}$ The Rainbow Division Veterans' Association desired to erect a memorial to the division in Ohio, and felt that the remains of their first casualty should rest alongside the monument. Veterans of the Rainbow Division listed several reasons for having Private Bird's remains repatriated-his comrades from Marion wanted his body back home, no memorial to the $42^{\text {nd }}$ Division existed in the United States, and Bird's father desired his son's remains. ${ }^{117}$ "Under all circumstances," the veterans' group felt that the ABMC "should approve the application" for Bird's return home. In order to strengthen their claim, the Rainbow Division veterans included in an initial request to the ABMC a newspaper clipping that detailed the repatriation of American remains from Russia. They reasoned to ABMC Chairman Pershing that in light of these repatriations, it would be "discrimination to refuse the return of Bird's body."118 Edward Bird, Private Bird's father, involved himself in the attempts to get his son's remains back to Marion. Mr. Bird wrote to General Pershing informing the ABMC that when he made the initial decision to leave his son's body in France there was some "misapprehension." In the

\footnotetext{
${ }_{116}$ Rainbow Division Veterans to General Pershing, May 14, 1935, Box 181, Removal and Reinternments Folder, ABMC Records, RG 117, NARA.

117 Ibid.

118 Ibid.
} 
present he wanted the body back and felt that if it was "the desire of the closest kin to have the body returned, that feeling should have precedent over everything else."119 Bird went on to express his dissatisfaction that Gold Star Mothers had more political clout than grieving American fathers stating that "Gold Star Fathers have feelings also," and that the complaints of mothers not wanting their sons burial plots disturbed abroad just so one body might go home seemed unfair. ${ }^{120}$

Media outlets related attempts to get Dyer Bird's body back to Ohio to a receptive public. Their coverage caused one relative of Dyer to contact the ABMC and let the government know what kind of man Dyer's father was. Signing only as "relative of Dyer Bird," the author of the ABMC letter reported that Edward Bird was "the father, but not a father" to Dyer. ${ }^{121}$ He reportedly "deserted the poor babe" after his mother died months into his life. After that, he "never done anything for the boy," and this made the relative ponder why "he wants the boys dead and deceased body now" if he "didn't want him alife [sic] or "right after he was killed" to "bury beside his mother." The anonymous relative concluded that Dyer's father "Drank enough whiskey to support a dozen children" and only became involved with the $42^{\text {nd }}$ Division's attempts to get the body back to Ohio because he felt there was "money and credid [sic] that might come with it. ${ }^{122}$ It was the relative's hope that General Pershing's ABMC hold firm to its norepatriation policy and "let the poor boy rest where he is." ${ }^{123}$ This saddening story

\footnotetext{
119 Edward Bird to John Pershing, July 10, 1935, Box 181, Removal and Reinternments Folder, ABMC Records, RG 117, NARA.

120 Ibid.

${ }^{121}$ Relative of Dyer Bird to John Pershing, June 9, 1935, Box 181, Removal and Reinternments Folder, ABMC Records, RG 117, NARA.

122 Ibid.

123 Ibid.
} 
shows that each body left abroad had a story. In Private Bird's case, the story revealed that his government, not his family, was likely best suited to care for his remains.

The ABMC ultimately decided to not break precedent and left Private Bird in the Meuse-Argonne American Cemetery. It is doubtful that the unknown relative's sad story had much to do with the decision. Notification went out that the $42^{\text {nd }}$ Division that the ABMC rejected the quest about a week prior to the arrival of the relative's letter. General Pershing revealed in his denial letter the "responsibility" that his commission had to "thousands of parents and other relatives whose loved ones sleep in American cemeteries" to "protect the resting places from disturbing and disintegrating influences."124 Pershing's sentiment indicated a care for the dead that Private Bird's own father seemingly would not have provided. Evidence suggests that the letter of Bird's concerned relative did reach Pershing's desk because the almost illegible letter was typed and annotated with a note that it was going to Pershing. The content of the letter probably gave added satisfaction to his decision. This is further validated by the fact that Pershing did not write Private Bird's father back, but instead had his staff do so with a rather short note that "adherence" to policy was "essential."125

Dyer Bird's body rested not in unfriendly Russian soil, but in what the American government felt was "the most impressive cemetery in the world." ${ }^{126}$ Bird's body represented something larger than the sacrifice of one man, or one division. He represented the United States and to "remove any body" was "unthinkable" as it would

\footnotetext{
124 John Pershing to Marcus Manning, May 23, 1935, Box 181, Removal and Reinternments Folder, ABMC Records, RG 117, NARA. 125 James Magnum to Edward Bird, July 13, 1935, Box 181, Removal and Reinternments Folder, ABMC Records, RG 117, NARA. 126 Xenophon H. Price to Chaplain Earl L. Holliday, October 15, 1934, Box 181, Removal and Reinternments Folder, ABMC Records, RG 117, NARA .
} 
destroy their "state of perfection." 127 The memory the ABMC constructed for the remains they protected was rigid and calculated. It was a memory that served a purpose on European soil. It showed that that United States cared for its dead and would continue to do so. The resources that went into creating this message was not to be compromised under any circumstances-even when next-of-kin or vocal advocacy groups attempted to try. The memory of American war dead was to remain on European soil for the duration of their country's life. At the same time, just as much effort went to remove remains from the same war out of Russia.

\section{$\underline{\text { Conclusion }}$}

American policy makers spent nearly twenty-years crafting a discourse of sacrifice for Europe. Thus far, this works has shown varying attempts to make the discourse relevant by repurposing the memories of war remains to speak to the times. They were vehicles of collective security, incentive for debt collection, signs of antiBolshevism, and symbols of peace. The start of World War II, and eventual entrance of America into the conflict, simultaneously paused the discourse of past sacrifice and offered the promise of expanding it into the future. The thirty-thousand American remains left in Europe from World War I were joined by millions of living American soldiers in World War II, and later nearly a hundred-thousand more dead. The preservation of American World War I cemeteries during war certainly was not a major American concern in the fight against fascism. However, the issue continually received

127 Xenophon H. Price to Chaplain Earl L. Holliday, October 15, 1934, Box 181, Removal and Reinternments Folder, ABMC Records, RG 117, NARA. 
serious attention before, during, and after World War II. Over a hundred-thousand American soldier dead from World War II joined their American WWI counterparts in the friendly soil of allies. The diplomatic situation that the memory of these remains entered into was vastly different than the interwar. The hegemonic position of the United States meant that it initially did not have to tread so lightly in its dealing with European nations. Increasing hostilities of the Cold War, and fear of nuclear war, reinvigorated cultural diplomacy as an official program more than ever before in U.S. history. Memory of the World Wars fell under the umbrella of cultural diplomacy. American leaders struggled to create a discourse of the dead that applied to the Cold War. Many of the same tactics were followed, but new approaches to memory diplomacy were implemented as well. The fluctuations of American popularity from the end of World War II through the present forced the repackaging of memories assigned to American soldier dead abroad frequently. 


\section{Memory Diplomacy and the Second World War}

'Today, less than twenty years after the war in which they died, we cannot be sure that their graves may not soon be torn by bombs and shells. A war in Europe would be the ultimate defeat of all the hopes for which they went out to die. ${ }^{1}$

Corporal Trenton A. Cooper of the $29^{\text {th }}$ Division's $175^{\text {th }}$ Infantry Regiment participated in an early morning assault on July 13, 1944 to capture the strategically important junction town of St. Lo in Normandy, France. This attack was part of the allied advance from the D-Day landing beaches. An artillery shell struck Trenton during the advance into the town instantly killing him. John A. Cooper and his wife Laura received a telegram at their modest white farmhouse in eastern West Virginia on August 2, 1944 informing them that their youngest son had been missing in action since the day of the attack. Confirmation of their worst fears came by telegram a week later with news that Trenton died in the engagement. ${ }^{2}$ In the months and years that followed this horrible news, no closure came. The Coopers left their farmland and settled in a nearby town. They sporadically received correspondence from their government filling in the details of their son's death and asking them to make decisions about the disposition of his remains. Per the WWI custom, the U.S. government offered to pay the Coopers for the return of Trenton's remains to West Virginia, but also promised to meticulously tend his grave for the perpetuity of time should he stay in France. Trenton's parents ultimately decided to leave their son near the field where he died. Based on a letter to

\footnotetext{
${ }^{1}$ P.J. Philip, "Bullitt Deplores European Conflict," The New York Times, May 30, 1938 in ProQuest Historical Newspapers.

${ }^{2}$ Western Union telegrams from the Adjutant General to the Cooper family, August 2 \& 8, 1944. The Cooper family generously made these documents available to the author.
} 
the Quartermaster General regarding Trenton's personal possessions at the time of his death it is doubtful that this was a decision based upon strong patriotic convictions. John wrote as a broken man in the letter, stating that he cared nothing for the "value of anything he [Trenton] possessed ... because the Government hasn't got money enough to pay for the kind of boy we lost." 3 Regardless, the symbolic reimbursement offered came in the form of a gravesite in the American Battle Monument Commission's Normandy American Cemetery.

The scenario described above repeated over 100,000 times in American households following World War II. 4 No national battle for American World War II bodies ever reached the caliber of the post-WWI debate. Even so, it is highly unlikely that John Cooper, and other next-of-kin who made a similar decision, completely understood, or cared, about the symbolic importance that their beloved remains embodied in death. These mourners cared about the brutally created void left for the remainder of their lives. As shown in previous chapters, some families surely relinquished their remains because of personal convictions that dead soldiers should remain where they fell. Others saw it as their patriotic duty. Many, like the Coopers, saw the delayed return of a corpse they could never view as only a way to reopen emotional wounds. The desire to not relive the grief influenced their decision to leave their dead abroad. It is arguable that for families whose loved ones died in that war, the remains were "frozen in time, in a specific and unchangeable context" that few gestures

\footnotetext{
3 John Cooper to Effects Quartermaster, March 7, 1945, Individual Deceased Personnel File of Corporal Trenton A. Cooper, National Personnel Records Center (NPRC), St. Louis, Missouri.

4 The ABMC's website maintains that "presently there are 124,905 U.S. war dead interred at these cemeteries, 30,921 of World War I, 93,234 of World War II and 750 of the Mexican War.” From, www.ABMC.gov, accessed September 1, 2014.
} 
could alter. 5 This assertion might be true on the level of individual loss, but its accuracy is questionable on the plane of national commemoration. The federal government's uses of the remains in the future indicated that they were quite unfrozen in time and able to evolve. As families grappled with their losses differently, the remains of their casualties joined others in foreign cemeteries to create a unified message of American sacrifice for a new world order, led by the United States.

Attempts from American and French leaders to promote European peace through memories of American World War I dead in France failed, non-surprisingly. This failure did not diminish the utility of American war dead to bolster international commitments once war began, however. American World War I remains in France continued to serve as a bond between France and the United States even after Nazi occupation of France. French officials circumvented the Vichy government and cared for American remains in the absence of the ABMC. Once the United States entered into WWII, the ABMC was among the first group of Americans to return to the European continent. The ABMC took steps to ensure that the new generation of American military dead, like Trenton Cooper, might join the WWI burials in France. It did so by beautifying its World War I sites of memory. Allied victory in World War II came at a high price. Over one-hundred thousand American dead from World War II stayed in France and built on the memory of Great War dead already present. The new memory was markedly different. Instead of a memory reflecting hope of a powerful U.S. presence abroad, the new memory reflected real military power. The United States emerged from World War II as a world superpower. A more expansive ABMC, and its

5 John Neff, Honoring the Civil War Dead: Commemoration and the Problems of Reconciliation (The University of Kansas Press, 2005), 7-8. 
more assertive memory reflected this hegemonic position going into the Cold War. $\mathrm{ABMC}$ attempts to erase the memory of dishonorable American military also reflected the increasing power of the federal government to construct a specific message through its war dead. 6

The ABMC During WWII

Following the ABMC's major dedications in 1937, the United States Congress took steps to reorganize the government and save costs. The ABMC's esteemed chairman, General Pershing, placed his beloved commission on the sacrificial altar. He wrote Secretary of War Harry Woodring in the first days of 1938 that the "duties of the American Battle Monuments Commission" should transfer to the War Department and that the "ABMC "should cease to exist."7 Pershing's only request was to delay the transfer until the ABMC's historical section finalized its revised guidebook and A.E.F. unit histories. ${ }^{8}$ President Franklin Roosevelt wrote Pershing a week later thanking him for his Commission's work and his "desire to cooperate." 9 Secretary of War Woodring wrote Pershing the same day as Roosevelt to let the aging general know that as soon as the

${ }^{6}$ Investigations of the National War Effort: House Report of the Committee on Military Affairs, Seventy-Ninth Congress, Second Session, House Resolution 20, A Resolution Authorizing the Committee on Military Affairs to Study the Progress of the National War Effort, June 1946 (Washington, DC: Government Printing Office, 1946), 3. The U.S. military executed one-hundred-forty-one American service members during World War II for murder, rape, or desertion. Of the 141, ninety-six rest in the friendly soil of France.

7 Pershing to Secretary of War Woodring, January 8, 1938, Box 7, Pershing Correspondence File, ABMC Records, RG 117, NARA.

8 Ibid.

9 Franklin Roosevelt to John Pershing, January 18, 1938, Box 7, Pershing Correspondence File, ABMC Records, RG 117, NARA. 
completion of the ABMC's publication work was reported, terminating "action will be taken."10

It is unclear what motivated this cooperation from General Pershing. The ABMC had the reputation of being Pershing's "favorite child," something that he defended from all attacks. ${ }^{11}$ It is unlikely that the leadership of the ABMC felt that their sites of memory actually succeeded in assuring peace. Fascist leaders had revealed aggressive foreign policy impulses and a Japanese invasion of China was well underway at this time. Perhaps the transition of the ABMC's duties back to the War Department signified a fear that that the military should once again oversee commemoration because another war seemed inevitable. The most likely explanation for Pershing's letter was political maneuvering. He masked his willingness to cooperate with the open-ended request to keep the ABMC in operation until its publication works were finished. This delay would perhaps give the $\mathrm{ABMC}$ enough time to weather the reorganization storm and emerge intact. A letter from the ABMC's administrative secretary, Xenophon Price, indicated stall tactics. Price reported to Pershing that the delay might quell the ABMC's troubles and "quiet" talk of reorganization until the spring after more "opportunity" had been afforded to "take further steps in the matter." 12 Termination of the ABMC did not take place before the Second World War began. Most American military dead from the Great War became hostages of German aggression before Pearl Harbor brought the United States into the war. In war time, the ABMC remained the caretaker of American memory, although in a

\footnotetext{
${ }^{10}$ Harry Woodring to Pershing, January 18, 1938, Box 7, Pershing Correspondence File, ABMC Records, RG 117, NARA.

${ }^{11}$ Bentley Mott to Major Charles Shaw, April 23, 1945, Box 132, WWII Maintenance File, ABMC Records, RG 117, NARA.

12 Xenophon Price to John Pershing, January 23, 1938, Box 7, Pershing Correspondence File, ABMC Records, RG 117, NARA.
} 
limited fashion. American military bodies continued to strengthen the bond of France and America even as more soldiers died. French officials helped keep American sacred sites maintained, and the ABMC took steps to acquire all new American bodies for to implant a new generation of American memory on European soil.

In histories of the Second World War, scholars pay little to no attention to the millions of Great War dead spread throughout Europe. This is an understandable omission. The treatment of World War I dead during World War II contributed nothing to the outcome of the war. The far greater number of American dead in World War II also contributes to those dead overshadowing Great War remains. Memories of American World War I dead in France stood out on the European landscape as the only U.S. military presence in early WWII, however. Hitler's invasion of France began in the summer of 1940. As Nazis descended on Paris in early June, American and French officials made their ceremonial Memorial Day trips to the graves of Great War dead in Paris. The most prominent French official present was Premier Paul Reynaud, a leader who had ardently opposed German militarism through the interwar years. Within weeks of the ceremony, Reynaud found himself a prisoner of war. The looming capitulation of France brought a greater somberness to Memorial Day than usual. Ambassador William Bullitt temporarily put his frantic correspondence with Washington on hold and attended the American Memorial Day ceremonies. Despite appearing in public with great resolve, Bullitt feared he could "be blown up" before ever seeing America again. ${ }^{13}$ That same day, Bullitt telegraphed President Roosevelt that

\footnotetext{
${ }_{13}$ Bullitt to President Roosevelt, May 30, 1944 from Orville H. Bullitt ed., Correspondence Between Franking D. Roosevelt and William C. Bullitt: For the President, Personal and Secret (Boston: Houghton Mifflin Company, 1972), 441.
} 
"Germans may reach Paris very soon."14 The ambassador feared the actions of French communists more than Nazi occupiers. He warned President Roosevelt of the likelihood that "communists of industrial suburbs will seize and loot the city," and a "cruel, but orderly German regime will be installed."15 Bullitt promised Roosevelt that he would remain in Paris and do his best to "save as many lives as possible and keep the flag flying." ${ }^{16}$ Bullitt generally did not immerse himself in memorial ceremonies nearly as much as previous American ambassadors to France had. He felt that previous Ambassadors spent far too much time attending such events because they "spoke no French and did no real work." 17 It was "impossible to do real work and handle the function side of life as well," Bullitt ascertained. ${ }^{18}$ In a period where calculated diplomacy was needed to stabilize the international situation, Bullitt chose his social obligations carefully. Memorial Day was one occasion that he did not abandon. The 1940 Memorial Day had extra symbolic importance. He turned to American dead from World War I to help the French find hope in a dire situation.

Memorial Day spectators realized the impending arrival of German troops in Paris. American journalists reported that "services could not be held at some American war cemeteries in France today, as they have been under [German] bombardment." The commander of the American Legion's Paris Post lamented that "the marble tombstones of American war dead were shattered by bombs." ${ }^{19}$ Some American World War I

\footnotetext{
14 Ibid.

15 Ibid.

16 Ibid.

${ }_{17}$ Bullitt to Judge Moore, "July 5, 1937 from Orville H. Bullitt ed., Correspondence Between Franklin D. Roosevelt and William C. Bullitt, 223.

18 Ibid.

19 "American War Dead are Honored in Paris," The New York Times, May 31, 1940 inProquest Historical Newspapers.
} 
cemeteries did indeed suffer damage from Nazi shelling during the blitzkrieg, however, the American Legion commander's accusation that Nazis actively bombed American graves was exaggerated. Still, in one of the darkest hours of France in the twentieth century prominent leaders from France and the United States traveled to American cemeteries to pay respect to the dead with German occupation looming. French and American citizens did not explicitly write about what American World War I bodies in France meant to them as Nazi takeover loomed. Yet, the consistency of FrancoAmerican interaction with World War I dead throughout the interwar years offers insight into the meanings these bodies had for both nations. By 1939, the American World War I remains had been a part of the French landscape for two decades. Both the French and Americans periodically read of commemorative services at U.S. cemeteries each year and considerable numbers from each nation participated in the ceremonies. Leaders from each nation contextualized the meanings of American sacrifice and its implications for future relations. American pilgrims to their graves on French soil found comfort seeing French reverence. Up until World War II, the presence of American remains in France and consistent commemoration surely brought comfort. The remains showed France continued American support. French reverence for American dead indicated a loyal partner. The mental image of German artillery churning up American dead resting in France was an alarming signal to both nations of what might come.

The disturbed respite of the dead coincided with broken peace. Americans who had trusted their government to care for their dead overseas worried about the condition of cemeteries. A Pennsylvania father wrote Secretary of State Cordell Hull shortly after France fell to the Nazis hoping to find out what happened to American cemeteries in the takeover. He hoped that the State Department could relieve him of 
much anxiety regarding the condition of his son's grave in the Meuse-Argonne American Cemetery. ${ }^{20}$ The State Department replied that they received no official information regarding destruction of American cemeteries in France, but they would pass on the letter to the staff of the ABMC because they remained in "intimate contact" with American cemeteries. ${ }^{21}$ A report to the State Department the following month provided answers to concerned families. During the German blitzkrieg, the most damage done to American cemeteries took place at Belleau Wood where "one hundred headstones [were] damaged by shell fire, [the] chapel chipped by shell fragments" and at "Romagne [where] fifty headstones [were] damaged by shell fire" and a flight of stairs at Montfaucon was damaged by a bomb. ${ }^{22}$ American concern over its World War I sites of memory in Europe halted the dissolution of the American Battle Monuments Commission discussed in early 1938. The ABMC remained the caretaker of American memory throughout World War II.

Despite Nazi occupation of Paris, and the absence of a legitimate French government there, America retained a strong presence in the French capital. Instead of fleeing alongside French government officials, Ambassador William Bullitt maintained America's Parisian embassy despite the diplomatic withdrawal of most other major nations. ${ }^{23}$ Bullitt found that in this time of crisis "thousands of people of all nationalities turned to us in despair for advice and comfort." 24 The Nazi occupation of

\footnotetext{
${ }^{20}$ Mr. Gallagher to Secretary of State Cordell Hull, June 25, 1940, Box 1471, Cemeteries in Wartime Folder, Department of State, Central Decimal 1930-39, RG 59, NARA.

${ }^{21}$ Robert Pell to J.M. Gallagher, July 30, 1940,Box 1471, Cemeteries in Wartime Folder, Department of State, Central Decimal 1930-39, RG 59, NARA.

22 Watermann to Secretary of State, July 17, 1940, ,Box 1471, Cemeteries in Wartime Folder, Department of State, Central Decimal 1930-39, RG 59, NARA.

23 Bullitt to Secretary of State, June 11, 1940 from Orville H. Bullitt ed., Correspondence Between Franklin D. Roosevelt and William C. Bullitt,466. 24 Ibid.
} 
France made a Franco-American alliance a dangerous liability for the United States. Ambassador Bullitt stubbornly remained in Paris in hopes of protecting the capital from communist and fascist riots, however. When the inevitability of France's fall became evident, Bullitt requested that the State Department send him twelve Thompson submachine guns with ammunition for use by the Embassy. He reasoned that "if the French Government should be forced to leave Paris, its place would be taken by a communist mob.” ${ }^{25}$ When the French Government evacuated Paris for Bordeaux, Bullitt remained because, in his words, "no American Ambassador in history had ever left Paris and I had no intention of leaving Paris so long as I thought I could be of use.”26 Days later, President Roosevelt "strongly recommended that if all foreign chiefs of mission follow the French Government to its temporary Capital, you should do likewise.”27 Bullitt chose not to comply. Shortly after the Nazi invasion, he reported that through the difficult transition, "France remained friendly with the United States," and that "all American institutions remained open" and that "the American hospital did magnificent work in caring for hundreds of wounded" throughout the Battle of France. ${ }^{28}$

The American Battle Monuments was one of the organizations that remained active in France through the German takeover. Completion of the ABMC's final construction projects took place just prior to France's fall. The concern shown by American families about German destruction of graves in its military advance indicated

\footnotetext{
25 Bullitt to Secretary of State, June 8, 1940 from Orville H. Bullitt ed., Correspondence Between Franking D. Roosevelt and William C. Bullitt, 455 .

${ }^{26}$ Bullitt to Secretary of State, June 9, 1940 from Orville H. Bullitt ed., Correspondence Between Franking D. Roosevelt and William C. Bullitt,456-57.

27 President Roosevelt to American Embassy, June 11, 1940 from Orville H. Bullitt ed., Correspondence Between Franking D. Roosevelt and William C. Bullitt, 465.

28 "Bullitt Recounts Seizure of France," The New York Times, July 14, 1940 in Proquest Historical Newspaper.
} 
that World War I memory was very much in the public consciousness as a new war began. General Pershing, although aged and in failing health, remained attentive of the new World War. The ABMC's wartime mission in France was not an easy one. During the German invasion, some ABMC officials went to Dreux, while others worked from the U.S. Embassy in Paris. The trip from Paris to Dreux in wartime was not leisurely. German aircraft did not distinguish between Americans and French citizens in moving convoys. One ABMC employee fleeing with his family was caught in a group of French refugees and "was fired on by German aircraft." Physical harm came to nobody in his party, yet his son faced a narrow escape when his hat and their car were riddled with bullets. ${ }^{29}$ This type of incident raised fear in Major Charles G. Holle, the ABMC's European officer during the initial stages of German occupation. In the months after the German invasion, Major Holle urged General Pershing to consider an evacuation plan for ABMC in the event that the United States became involved in the war. The impetus for Holle's concern came from German treatment of staff from the ABMC's British equivalent, the Imperial War Graves Commission. This British memorial commission did not bother to form an evacuation plan for its employees before declaring war on Germany. As a result, their employees "had to shift for themselves" during the Nazi advance. ${ }^{\circ}$ Some escaped, but the rest ended up in German concentration camps. Holle saw no indication that Germans would treat ABMC employees differently if the United States declared war. He was concerned further by

\footnotetext{
29 "Information on leaving Paris for Temporary Offices at Dreux and Girends, 1939-1940" Box 132, ABMC Records, RG 117, NARA. 30 Charles Holle to John Pershing, November 25, 1940, Box 8, Pershing Correspondence File, ABMC Records, RG 117, NARA.
} 
the apparent lack of concern the State Department had shown the ABMC throughout the occupation. ${ }^{31}$

Much of the ABMC correspondence with Washington throughout 1940-41 revealed that State Department officials placed a low value on the ABMC's commemorative mission during the German invasion. ABMC officers had to battle for office space, rations, approval to travel to their cemeteries in restricted zones, and for inclusion in official American evacuation plans. ${ }^{22}$ American ABMC personnel were in a slightly more vulnerable situation than American government workers near Paris because of their postings in eastern France. Holle estimated that it would take approximately a week for many ABMC staffers to get to Paris after Washington called for an evacuation. It was Holle's hope that Pershing could push to State Department to place American ABMC employees on the official list of individuals requiring evacuation.

General Pershing officially recalled all American ABMC employees to Paris on May 5, 1941, and then to the United States a week later.33 In June 1941, the final American employees left Paris for transport home through Portugal.34 The departure of the ABMC did not signal abandonment of America's World War I dead. Instead, it again opened up avenues of diplomacy through memory and allowed the French to physically show their commitment to American through its dead. Six months after Paris fell, French General Désiré-Pierre-Sylvestre Vincensini, Secretariat General des Anciens

\footnotetext{
${ }^{31}$ Charles Holle to John Pershing, November 25, 1940, Box 8, Pershing Correspondence File, ABMC Records, RG 117, NARA.

32 Ibid. Also see Memorandum, August 9, 1941, Box 133, Evacuation Plans, ABMC Records, RG 117, NARA. This memo demonstrates petty bickering between the ABMC and Embassy.

33 T. Bentley Mott to Secretary of the American Battle Monuments Commission, August 8, 1941, Box 133, WWII Maintenance File, ABMC Records, RG 117, NARA.

34 "Information on leaving Paris for Temporary Offices at Dreux and Girends, 1939-1940" Box 132, ABMC Records, RG 117, NARA.
} 
Combattants informed the ABMC that France would take over all American military cemeteries and "place [French] caretakers and laborers in them as rapidly as possible" should the ABMC evacuate France.35 General Vincensini had already done this for the British, although he was only concerned with upkeep of memorials that included cemeteries. ${ }^{36}$ Before the ABMC left France, its wartime executive in Europe, T. Bentley Mott, drafted an official agreement with Vincensini regarding French upkeep. In the days before leaving France, Vincensini agreed to take over the entire operation of the ABMC unless absolute necessity arose to stop providing the service. 37 Before disbanding, the French government created a special account to fund such a project and funnel allied money into cemetery upkeep. France did this to oblige the legal convention that they "must continue the maintenance and upkeep of all war graves" of allies buried in its national territory. ${ }^{8} 8$ With complete trust in France to maintain American sacred space, America's guardians of its World War I memory left France for the first time since the end of the Great War. General Pershing concluded that there was "nothing to do at present except to maintain the status quo and await the end of the war in Europe."39 A renewed focus on America's caretakers of memory increased only after America became involved in the war and found success on battlefields. Then, memory served as a morale booster to troops and a means for the government to save money with future repatriations. Despite the ABMC's difficulty with the State Department, its

\footnotetext{
35 ABMC European Office to Washington Office, November 26, 1941, Box 133, WWII Maintenance File, ABMC Records, RG 117, NARA.

${ }^{3}$ Ibid.

37 Ibid.

${ }^{38}$ Letter to French Ministry of the Interior,”, June 12, 1941, Box 133, WWII Maintenance File, ABMC Records, RG 117, NARA.

39 Pershing to James Magnum, March 7, 1941, Box 8, Pershing Correspondence File, ABMC Records, RG 117 , NARA.
} 
leaders had the foresight to put policies in place that kept ABMC sites functional enough to for easy reactivation as sites for public diplomacy when the government needed them. America's memory keepers would be among the ranks of the liberating armies.

The ABMC did not wait for the American army liberate France before sending T. Bentley Mott to make sure that Vincensini adhered to their agreement. In May 1942, Mott arrived in Vichy, France and attempted to get German permission to travel into Paris and visit the U.S. cemeteries. The Germans denied Mott's request, but General Vincensini maintained a sub-office in Vichy that put Mott in contact with French ABMC employees operating out of the former superintendent's quarters in Suresnes. Through contact with Suresnes, Mott was able to arrange for a French employee to travel through France and assess conditions of American cemeteries. From this Frenchman's report, Mott assured the ABMC's Washington office that Vincensini's arrangement had "worked out successfully and "there was no hitch, difficulty, or friction." 40 Astonishingly, Mott reported to Washington that although Americans had not been present on these sacred sites for a year, the "cordial spirit" and resourcefulness of the French had kept the American cemeteries in "pleasing appearance-grass cut, shrubbery cared for, and not one sign of neglect in any of them." ${ }^{41}$ With this peace of mind, Mott traveled to Cannes where his wife could recover from an illness in a warmer climate. There, he was captured by the Italian Army and transferred to the Germans who sent him to a prison camp in the eastern France town of Vittel. Mott spent a month in prison where he admittedly "was not treated badly" before being sent to Paris for four months awaiting a

${ }^{40}$ Mott to General Pershing, May 5, 1944, Box 133, WWII Maintenance File, ABMC Records, RG 117, NARA. ${ }^{41}$ Ibid. 
prisoner exchange. ${ }^{22}$ In Paris, Mott again oversaw the work of the ABMC before his exchange sent him to New York. American armies rapidly advanced past the ABMC's World War I cemeteries in the year after Mott's exchange and erected temporary WWII cemeteries near them.

Within three months of D-Day, General Eisenhower personally wrote to General Pershing at Walter Reed Hospital to report on the WWI cemeteries he gained intimate knowledge of while writing the ABMC's first guidebook as a junior office. Eisenhower's message was a birthday gift to Pershing. He conveyed greetings from his army, made up of the sons of Pershing's soldiers, who tread the same ground thirty-five years ago. 43 More importantly, he thought it would please the General of the Armies that most of the WWI cemeteries had "weathered the misfortunes of the past four years so well, with normal depreciation only slightly accelerated." Eisenhower attributed this to admirable devotion of the French caretakers.44 French care for American dead of WWI and its new WWII dead received much attention in initial ABMC correspondence after the war.

French laborers tended to American graves with little pay (by American standards), and French villagers meticulously recorded the names of fallen American aviators and provided them Christian burials in local cemeteries before the American ground forces liberated France.45 When the ABMC's Paris office reopened, it planned to reward the French employees who faithfully maintained sacred American sites throughout the war.

42 Ibid.

43 Most U.S. World War Cemeteries in France, Belgium in Good Condition, October 20, 1944, Box 133, WWII Maintenance File, ABMC Records, RG 117, NARA.

44 General Eisenhower to General Pershing, October 13, 1944, Box 133, WWII Maintenance File, ABMC Records, RG 117, NARA.

45 Mott to General Pershing, May 5, 1944, Box 133, WWII Maintenance File, ABMC Records, RG 117, NARA. 
Reward came in varying forms-salary increases, continued employment, and U.S. Government certificates of thanks. 46

Interestingly, German soldiers also displayed considerable respect to American cemeteries also. Few instances of German desecration of American cemeteries exist. Most examples of German desecration happened at the superintendents' houses within ABMC cemeteries. Germans reportedly looted furniture, dismantled automobiles for parts, and jokingly wrote "A. Hitler and Mussolini," in ABMC visitor logbooks.47 Reports of German desecration of American graves only came from one cemetery during the war. In this case, "some German soldiers broke in one night and knocked over some Star of David headstones on Jewish soldiers' graves.”48 The Frenchman caring for the cemetery immediately reported the vandalism to the German officer in charge of the region and he remarkably "not only had the headstones replaced but put a guard in the cemetery to prevent further vandalism." 49 One of the most publicized episodes of German disrespect of American soldier dead came from American reports in 1941 that the German military buried one of its dead soldiers in the Meuse-Argonne American Cemetery. Upon hearing this, veterans groups in the U.S. demanded the removal of an enemy from “American soil.” 50 German respect for American cemeteries likely helped the French do their good work, yet received little notation.

\footnotetext{
${ }^{46}$ Ibid.

47 Most U.S. World War Cemeteries in France, Belgium in Good Condition, October 20, 1944, Box 133, WWII Maintenance File, ABMC Records, RG 117, NARA.

48 William Jones to Dr. Richard Sommers, May 16, 1988, Box 1, William Jones Papers, ABMC Folder, USAHEC, Carlisle.

49 Ibid.

$5^{0}$ Resolution from Des Moines Iowa Veterans, August 13, 1941, Box 1471, Cemeteries in Wartime Folder, Department of State, Central Decimal 1930-39, RG 59, NARA.
} 
The powerful discourse of American war dead commanded respect even under the most dire of times for France and the United States. Foresight of the ABMC and French care for American remains during World War II allowed American policy makers seamlessly to build a new memory of war immediately after German soldiers ceded ground. Thousands more Americans died during World War II and American military leaders attempted to circumvent the repatriation debate that took place after WWI. When Colonel Mott returned to his Paris post at the end of the war he hoped to create a willingness in Americans to relinquish their dead to the American government so that the discourse of sacrifice and memory could continue even stronger than before. Colonel Mott wrote his vision of the future he saw for American memory in Europe to General Pershing over Christmas of 1944. Mott was an American with a strong grasp on the political uses of sites of memory. He was at the side of Myron Herrick through much of the interwar, and played a pivotal role in the ABMC throughout the Second World War.

Mott shared some observations with Washington that he had recently made visiting war remains. He offered recommendations for what he thought the U.S. government should do with new American dead. Mott contended that even though the war was not officially over, many soldiers and mourning family members had traveled to the battlefields to visit the temporary graves of those killed in action. He recognized that during these trips, most pilgrims also made stops at the ABMC's WWI cemeteries to show their respect for the previous generation of American fallen. Mott saw this as an opportunity the ABMC needed to seize. These visitors surely would come away from their trip with some impression of how America cared for fallen soldiers and likely would share their opinions domestically. Colonel Mott recommended that the ABMC 
spend money immediately to beautify the cemeteries because the "more beautiful and imposing the graveyards" were, the more likely a mourning family member to entrust remains with "Uncle Sam." ${ }^{11}$ Money spent "now" surely could save repatriation money in the future and ensure that the discourse of American sacrifice defined by World War I bodies might become even stronger in the post-war world. ${ }^{2}$ Mott informed the ABMC that he had discussed the matter with General Eisenhower's staff and that they agreed with his assessment and hoped that perceived care for WWI dead would bring "free and cheerful acceptance" amongst Americans for leaving "all" bodies buried abroad.53

This proactive agenda had an objective driven by more than interest in saving funds on repatriation. Mott and Eisenhower's staff wished to avoid the heated public debate about where American war remains should permanently rest that overshadowed the years after World War I. American officers in Europe during World War II witnessed firsthand the powerful reactions that the resting places of World War I soldiers had on contemporary visitors. If the U.S. government acted swiftly, and with authority, all American bodies from WWII could possibly join those of the Great War perpetuating the discourse of sacrifice sanctioned by the dead. By this stage in the war, it appeared that a realization existed among those in power that more bodies present meant a stronger memory.

The number of potential American overseas burials was large, as was American exposure to death. The scope of American combat death in World War II was staggering

51 "Mott to General Pershing," December 26, 1944, Box 133, WWII Maintenance File, ABMC Records, RG 117, NARA. Pershing likely was not the primary recipient of this because he was an invalid at Walter Reed by this point. Acting Chairman of the ABMC Robert Woodside probably read the letter. $5^{2}$ Ibid.

53“Mott to General Pershing,” December 26, 1944, Box 133, WWII Maintenance File, ABMC Records, RG 117 , NARA. 
in comparison to previous U.S. wars. Nearly 300,000 Americans died fighting the Axis Powers. The military made every effort to identify all American dead during the war, but countless numbers lay unknown on battlefields of the land and sea. Those recovered rested in approximately 209 temporary cemeteries.54 War correspondent Ernie Pyle frequently wrote about his encounters with the dead and burials in his accounts to the American public. In the days following D-Day, he reflected on carnage he saw on the beachhead in the aftermath of the Allied landings. "It was a lovely day for strolling the seashore," after the invasion, Pyle told Americans. "Men were sleeping on the sand, some of them sleeping forever. Men were floating in the water, but they didn't know they were floating in the water, for they were dead." 55 Combat was not new to Pyle at this point, he had imbedded with U.S. forces in Africa and Italy prior to the main European invasion. Pyle volunteered to help soldiers carry American and German corpses for burial following D-Day. He did this "partly because the group needed an extra man, and partly because I was forcing myself to get used to it, for you can't hide from death when you're in war."56 One young American soldier in the burial party showed reluctance carrying a corpse in advanced stages of decomposition. An older soldier urged him to "take hold of him dammit, you might as well get used to it, for you'll be carrying plenty of dead ones from now on." 57 The group enclosed the bodies in mattress covers and buried them close together at a depth of five feet. Eventually a white wooden cross marked their presence. Often the corpses moved multiple times

\footnotetext{
54 Joseph Shomon, Crosses in the Wind (New York, New York: Stratford House, 1947), Foreword.

55 David Nichols ed., Ernie's War: The Best of Ernie Pyle's World War II Dispatches (New York, New

York: Random House, 1986), 281.

${ }^{6}$ Ibid., 285.

57 Ibid., 286.
} 
before finally resting in peace. Sometimes enemy artillery churned them up, more often the military moved them to more permanent resting places.

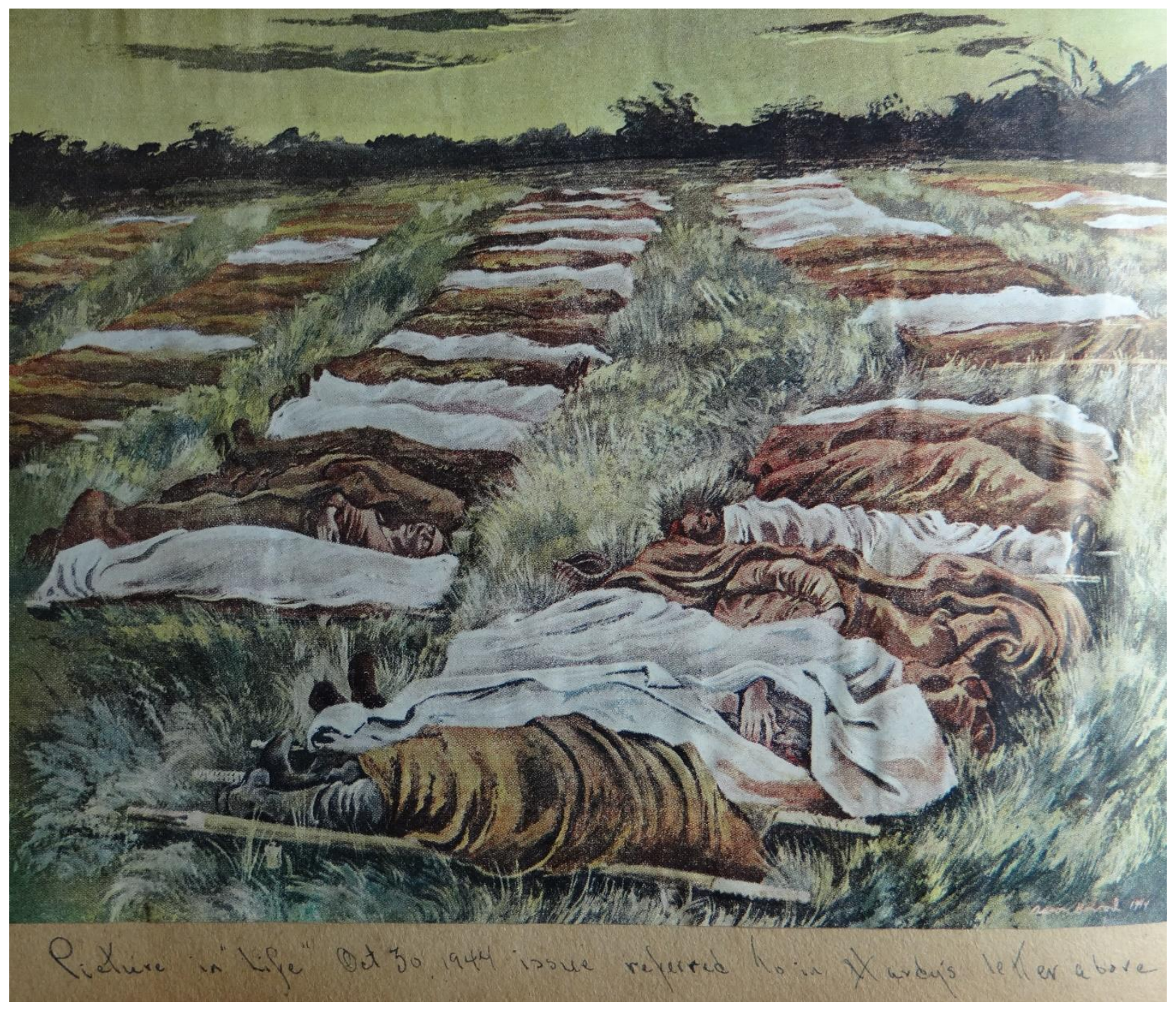

Photo 4.1: "American soldiers before burial," October 30, 1944, clipping from the scrapbook of Hardy Derx. $606^{\text {th }}$ Graves Registration Service. Source: Derx Papers, USAHEC, Carlisle, PA.

Death became something most Americans needed to deal with during the Second World War. A military publication entitled Psychology for the Fighting Man offered 
U.S. military personnel headed for combat suggestions on dealing with death.

Americans going into combat needed to "accept the possibility of death as a natural part of their job." 58 Citizen soldiers possessed a natural horror to the "sight and smell of death and bloodshed."59 Solace was found, and "the repugnance overcome," by "seeing that the body of a friend gets thoughtful care and a decent burial." ${ }^{\circ}$ The U.S. Armed Forces adhered to this commitment to the dead. The study cited care for American dead in the Great War as assurance to American World War II soldiers fearing their demise. Just as in the Great War, American combat forces would "weld together in a close knit group" and do everything possible to bring the body of a comrade back for burial, even if it meant going into harm's way and "gathering the body up in a basket." ${ }^{1}$ Psychologists preparing the study felt that this commitment to the dead would "make death seem a less complete cutting off" because the "tie of comradeship would carry on even then [after death].”62 Joseph Shomon, an officer in the 611 ${ }^{\text {th }}$ Quartermaster Graves Registration Company, which buried some 21,00o dead American troops in Europe following WWII, verified this level of commitment to the dead. Shomon intended his 1947 work, Crosses in the Wind to inform the public about "burial of our casualties and their care"63 This was a "little-publicized," but important aspect of the war. Shomon spent his entire overseas service handling corpses. Already by 1947, he sensed a "feeling of uncertainty and apprehension" regarding the future. ${ }^{64}$ He decided to relate his

\footnotetext{
${ }^{8}$ Psychology for the Fighting Man: Prepared for the Fighting Man Himself by a Committee of the National Research Council (Washington, DC: The Infantry Journal, 1943), 347.

59 Ibid., 348.

60 Ibid.

${ }^{61}$ Ibid.

62 Ibid.

63 Joseph Shomon, Crosses in the Wind, Preface.

64 Ibid.
} 
experiences with the dead to Americans because he felt they needed a voice. "War is hell on earth-the dead are a silent testimonial."65 Shomon hoped that by explaining his work with the dead and the large scope of burial work, the living might work to prevent a future of war.

The discourse of the dead encountered by participants of the war and the ABMC shared similarities. Themes of comradeship after death, perpetual care, and lessons of sacrifice carried into the ABMC's post-WWII commemorative plans. The remains in ABMC cemeteries were not "cut-off" from the living. The U.S. government followed the same repatriation policy of WWI and gave American next-of-kin an option for final disposition of remains. Of the approximately 405,000 American dead of WWII, about 176,00o remained abroad buried in ABMC cemeteries or commemorated on walls of missing. ${ }^{66}$ Perhaps the aggressive policy to avoid a repatriation debate did help. The forty-four percent of corpses that remained abroad following WWII was significantly more than the thirty percent of World War I. ${ }^{67}$ The new remains entered into the same commemorative system as their predecessors, and the American discourse of sacrifice abroad congealed the two world wars into one. This discourse took on renewed importance as the United States navigated its new hegemonic status in the Cold War. As the United States fought an ideological battle with the Soviet Union, American war cemeteries became even more important diplomatic sites than they were in the interwar

\footnotetext{
65 Ibid.

66 The ABMC's website maintains that "presently there are 124,905 U.S. war dead interred at these cemeteries, 30,921 of World War I, 93,234 of World War II and 750 of the Mexican War." From, www.ABMC.gov, accessed September 1, 2014.

67 The ABMC's website maintains that "presently there are 124,905 U.S. war dead interred at these cemeteries, 30,921 of World War I, 93,234 of World War II and 750 of the Mexican War.” From, www.ABMC.gov, accessed September 1, 2014.
} 
years. American memory abroad in this new era underwent continued revision to address international situations and growing European feelings of anti-Americanism. The ABMC was under new leadership for the first time since its conception during this transitional era. General Pershing died in 1948. The Commission released a statement praising his leadership as a soldier and guardian of U.S. memory. Members of the ABMC did not regard Pershing a mere figurehead, but as the individual "primarily responsible" for erecting American cemeteries in Europe. 68 The impact of his commemorative vision lingered long after his death.

Robert Woodside, the ABMC's acting vice-Chairman since 1923, temporarily assumed Pershing position and inspected all cemeteries in 1949. Woodside was impressed that in only four years, the ABMC's European workers erased all scars of World War II from the American cemeteries. In an open letter to all ABMC overseas workers, Woodside laid out what he saw as their larger mission. "The people of our country and the spirits of the brave Americans who lie in these cemeteries, look to us to see that their sacrifices are fittingly commemorated." 69 Woodside felt that all ABMC staff abroad would face challenges to their "patriotism and loyalty" as World War II projects moved into the new decade. ${ }^{70}$ Yet, he felt confidence that the ABMC's long tradition of avoiding scandal would continue and its staff would continue to serve as America's “envoys of good will in a foreign land."71 Woodside’s remarks reflected anticipation that post-WWII Europe needed the presence of the ABMC and positive

\footnotetext{
68 Robert Woodside to Miss Pershing, "July 20, 1948, Box 8, Pershing Correspondence File, ABMC Records, RG 117, NARA.

69 Robert Woodside to ABMC European Staff, July 27 1949, Box 133, WWII Maintenance File, ABMC Records, RG 117, NARA.

70 Ibid.

${ }^{71}$ Ibid.
} 
American memories more than ever. The future looked uncertain and turbulent. The ABMC saw itself as bastion of goodwill.

\section{Expansion of the ABMC}

The ABMC's zone of commemoration following World War I was limited to the European continent where American soldiers fought and died. Following WWII, Congress allowed the ABMC to cast a world-wide net. ${ }^{22}$ Now, the ABMC maintained the authority to commemorate in the Pacific, Africa, the Philippines, and on "all federally owned or controlled territory within the United States and its possessions."73 This was indicative not only of the scope of American military engagements in WWII, but also the advantageous position of power the United States now held. The expansion of the ABMC's commemorative plan meant that new remains would go into non-European soil. Much thought went into the placement of these remains, and final decisions of where remains went reflected the hierarchy of diplomatic relations felt by leaders in Washington.

When the Congressional Hearings to continue the ABMC took place in 1946, Representative Frances Bolton from Ohio recalled observations she made overseas during WWII, when she visited various ABMC sites. She assured her colleagues on the House Committee on Foreign Affairs "that the reverence for the whole-the sense one has of the reverence with which everything has been done and the respect that is

\footnotetext{
${ }^{72}$ Hearings before the Committee on Foreign Affairs House of Representatives Seventy-Ninth Congress, First Session on H.R. 6393, May 15, 1946 (Washington, DC: Government Printing Office, 1946), 3. 73 Ibid.
} 
afforded to those men who lie there is something which, to my mind, tells something about America that needs telling." 74 This indicated that the proactive beautification taken by the ABMC during WWII indeed reverberated domestically. The story that America had to tell became much more important in the bipolar Cold War world. Part of telling the American story required casting American memory as exceptional in comparison to perceived enemies. Mrs. Bolton concluded her thought by contrasting U.S. care for soldier dead with Russia's lack thereof. Mrs. Bolton's son served in Eastern Europe disinterring Russian and German remains for identification following WWII. He reported to his mother that he was shocked at how Russians disregarded care for their fallen soldiers. 75 Thomas North, the ABMC's WWII administrative secretary, made similar observations about the Russians in his memoir. North indicated that when determining American cemetery sites for WWII, Russia briefly looked like a possible site because of their wartime alliance. The possibility quickly disappeared, however, due to the boorish "attitude of Soviet officials."76 Examples of the churlishness that North hinted at are found in the news the year after the war. The New York Times reported to Americans in 1946 that Soviets ordered towns in their German occupation zones to till up cemeteries and plant crops to address food shortages. 77 This type of perception of the Russians' disregard for war dead was not a new phenomenon post WWII. The tireless efforts to get American soldiers from WWI out of Russian soil in the mid-thirties indicated that serious consideration of permanent American burials in Russia likely never happened.

\footnotetext{
74 Ibid., 7.

75 Ibid.

${ }^{76}$ Thomas North, North's Manuscript (Unpublished, ABMC Historic Document), 47.

77Delbert Clark, "Germans Ordered to Till Cemeteries," The New York Times, December 19, 1946 in Proquest Historical Newspapers.
} 
The idea that American remains needed to rest in only friendly soil dominated commemorative decision-makers motives following WWII. Friendly soil was easy to designate for America following World War I because of the limited scope of its military operations and rather clear partnerships. World War II was trickier. For the United States, World War II was truly a world war. American military personnel fought not only in Europe, but on remote islands throughout the Pacific. Additionally, airmen and seaman fell throughout the globe, often in total isolation. While the Soviet Union was one of the greatest partners of the United States in wartime, a mutual distrust stemming from aggressiveness in both Moscow and Washington, made Russia seem unfriendly. It was clear that the soil of Axis nations Germany and Japan held no hints of amicability, both fought on until the end. Yet Italy, the birthplace of Fascism, eventually became a partner of the United States. The ABMC settled on the following factors when deciding where permanent American WWII resting places should be: sites of cemeteries needed to reflect offensive progress, they had to be accessible, each required a sense of natural beauty, promise of economic development was important, they would not be in enemy territory (Italy was appraised as co-belligerent), and not more than 10,000 American bodies should be concentrated in one area. ${ }^{78}$

If historians take the $\mathrm{ABMC}$ determinants for permanent cemetery locations at face value, there is little reason to questions why American military personnel were not buried in Germany or Japan-they were enemy belligerents. Yet, the pliability of these determinants to allow Italy to entomb American remains shows that ABMC policy was not entirely rigid. The situational bending of rules indicates a need for critical analysis

${ }^{78}$ Thomas North, One Soldier's Story, II-5. 
of ABMC burial sites. More than just depositories for dead, "overseas cemeteries served to symbolize U.S. global military commitments."79 Following World War II, American cemeteries came to represent not only a diplomatic commitment, but more of a military one. Again, more American military cemeteries went in Europe than the rest of the world, as did other signs of long term commitment-the Marshall Plan and NATO defense agreements.

The language used by the ABMC in dedications of WWII cemeteries also revealed that conceptions of friendship between nations were far stronger in Europe than other cemetery locations. President Eisenhower's 1960 dedicatory press releases for cemeteries in France, Belgium, and Luxembourg revealed that in European countries "friendly soil," and "friendship" moved the United States to inter remains. ${ }^{80}$ The address given on behalf of President Eisenhower at the American cemetery dedication in Carthage never spoke of the friendliness of the soil. Instead, it purported feelings that the living gathered in Carthage to dedicate the sacred ground needed to show more diligence "against all that might nullify their [the dead's] sacrifices." ${ }^{11}$ The use of the words conveying feelings of friendship was so common in dedications of ABMC cemeteries that the absence of such words jumped from the page. Instead of talking about the friendship of the United States and people of Carthage, the address spoke to the "unity" between allies who liberated the area from Axis control.82 Serving as Eisenhower's Assistant Staff Secretary, his son, John S.D. Eisenhower, reported his

\footnotetext{
79 Kurt Piehler, Remembering War the American Way (Washington, DC: Smithsonian Press, 1995), 132. 80 Dwight Eisenhower, "Dedication of the Cemetery and Memorial at Luxembourg," July 4, 1960, Box 158, ABMC Records, RG 117, NARA.

${ }^{81}$ Ibid.

82 Ibid.
} 
father's approval of the ABMC's "wording and purpose" in dedications, and noted that it was important to President Eisenhower for "consonance" in his dedication messages. ${ }^{83}$

The lack of friendly language in Eisenhower's Carthage address had deeper meanings. Eisenhower's call to remember the unity of allies in WWII was likely a response to strong feelings of anti-Americanism among French inhabitants of Tunisia. Following WWII, Tunisia was one of the North African countries that fought to free itself from the orbit of French colonialism. Official sovereignty did not come to Tunisia until 1956. That year, French Tunisians leveled violent attacks against the United States for its support of the Tunisian government. The initial reason for the 1956 protest came when American manufactured guns were found at the murder scene of two French nationalists in Tunisia. ${ }^{84}$ Over 10,000 French Tunisians gathered at the funeral. Anger over the murders combined with the widespread belief that the United States had "commercial designs" on French overseas possessions to create a volatile situation. Frustration turned to violence when hundreds of French protestors descended on the U.S. Consulate building and library where they destroyed $\$ 20,000$ worth of property while chanting "down with America." 85 It is noteworthy that such a location was not deemed friendly by the ABMC in Eisenhower's dedicatory address, and brings questions

83 John S.D. Eisenhower to General North, May 31, 1960, Box 158, ABMC Records, RG 117, NARA.

84 Thomas Brady, “Tunis Mob Sacks Two U.S. Offices: French Demonstrators Raid Consulate,” The New York Times, March 10, 1956 in Proquest Historical Newspapers.

85 Ibid. Also see Frank Costigliola, France and the United States, 108. For a definitive study of the superpowers Cold War conflict in the developing world see Odd Arne Westad, The Global Cold War: Third World Interventions and the Making of Our Times (New York: Cambridge University Press, 2005). The ABMC's cemetery at Carthage would prove to be a good location for future scholars to look for calculated memory diplomacy. It is a non-European location, a former protectorate of France, non-white, predominately non-Christian, and a location with remnants of the ancient Roman architecture so prevalent in ABMC architecture. Anti-American protest in Tunisia also coincided with American military escalation in Vietnam, another former French colony. Additionally, it is in the peripheral region of the globe where Washington and Moscow fought to implant their ideologies. 
to the surface about the relationship of American military memory with religion, colonialism, and race.

The Pacific Theater is another area of the ABMC commemorative zone to consider race based decisions. Historians have effectively shown that culturally, American soldiers felt not so different from their European enemies during World War II, particularly Germans. American G.I.s certainly did not view German enemies or Nazism fondly, but shared skin color and heritage made them seem like a less alien opponent. American soldiers frequently felt that the Germans fought "decently," and abided by conventional rules of war. ${ }^{86}$ They both feared and respected their skill and discipline as soldiers. As the war dragged on, they also were startled to find that the "German foe shared the universal characteristics of ordinary human beings." 87 The Japanese enemy that Americans faced in the Pacific was perceived entirely different. The Pacific Theater was fought more as a "race war" than a conventional military contest. ${ }^{88}$ Both Japan and the United States shared views of their own national exceptionalism, and soldiers from both sides fought with racial hatred for the other. To American soldiers, the Japanese were inhuman, inferior, barbaric, and ruthless. ${ }^{89}$ It was Japan, after all, that brought the United States into the war by a surprise attack on the U.S. Naval base at Pearl Harbor.

Evidence of American soldiers' perception of Japanese combatants as inhuman is found in wartime correspondence between the Joint Chiefs of Staff and U.S. custom

\footnotetext{
${ }^{86}$ Gerald Linderman, The World Within War: America's Combat Experience in World War II (Harvard University Press, 1997), 90.

87 Peter Schjrivers, Crash of Ruin: American Combat Soldiers in Europe during World War II (New York: New York University Press, 1998), 85. See Chapter 4, "The Enemies," for more explanation.

88 John Dower, War Without Mercy: Race and Power in the Pacific War (Random House Publishing, 1986), "Enemies."

89 Linderman, The World Within War, 167.
} 
officials at ports where American marines returned home from the Pacific. Customs officers in San Francisco reported that it was a growing practice of "marines to bring Japanese skulls into the United States as war trophies."9o This concerned the Joint Chiefs of Staff because the Japanese might use such accounts as anti-American propaganda and retaliate on the battlefield. There was also concern that marines were breaking the laws of war because "under the rules of land warfare a belligerent is obligated to give decent burial to enemy dead."91 Military leaders in Washington ordered commanders in the Pacific Theater to stop this practice, and urged port officials to obtain the skulls, if possible, and "destroy them by burning."92 Boiling down enemy heads and bringing them home for display did not meet the American definition of a decent burial.

American racial stereotypes fostered during World War II in the Pacific had applicability in the Cold War. The hatred that Americans felt towards the Japanese enemy "proved to be free-floating, and easily transferred to the new enemies: to Soviet and Chinese Communists, the Korean foe of the early 1950s, the Vietnamese enemy of the 1960 s and 1970s, and hostile, 'third-world' movements in general."93 The existence of this racial hatred is well documented, and race has also proven a reliable means for diplomatic historians to approach American relations with non-white nations-largely through the lens of paternalism and adherence to the supremacy of white Anglo-Saxon

90 “Control Over Importation of Undesirable War Trophies,” January 13, 1944, Box 154, Chairman's File, Records of the Joint Chiefs of Staff, Central Decimal 1942-45, RG 218, NARA.

${ }^{91}$ Ibid.

${ }^{2}$ George C. Marshall to Commissioner of Customs, December 27, 1943, Box 154, Chairman's File, Records of the Joint Chiefs of Staff, Central Decimal 1942-45, RG 218, NARA.

93 Dower, War Without Mercy, 19-20. 
male leadership.94 The fluidity of American racism towards the Japanese coincided with military commemorative practices. No U.S. military cemeteries went on Japanese islands, nor did any go in Korea or Vietnam in subsequent wars.

Despite scholarly recognition of U.S. racism towards peripheral nations, almost no racist undertones exist in the records of the $\mathrm{ABMC}$ regarding decisions to not bury Americans on Japanese soil. Racist motives to keep American military corpses out of Asia and other peripheral regions remained absent from ABMC meetings. Still, the ABMC's emphasis on burials in Europe correlated with a large "ambivalence" that Americans felt towards the regions that burials would not take place. America fought its next two wars in Asia, but in the final years of the 1940s, Western Europe remained America's political focus. 95 While blatant racism did not factor into the ABMC's reluctance to leave the thousands of remains temporarily interred in Pacific Island cemeteries, perceptions of friendly soil certainly did.

Meeting minutes from the ABMC's World War II planning phase reveal that much thought went into final selection of cemeteries. The Commission divided the world into commemorative zones and assigned commissioners to study the viability of each for burials. The "Pacific Area" question was tasked to some of the Commission's most important figures, acting Chairman Marine Corps General Alexander Vandergrift ( $1^{\text {st }}$ Marine Division) and future Chairman General George C. Marshall (U.S. Army Chief-of-Staff). ${ }^{96}$ During the meeting where commissioners received their

\footnotetext{
94 See Dudziak, Cold War Civil Rights: Race and the Image of American Democracy (Princeton University Press, 2000), Mary A. Renda, Taking Haiti: Military Occupation and the Culture of U.S. Imperialism 1915-1940 (UNC Press, 2001), and Michael Hunt, Ideology and U.S. Foreign Policy (Yale University Press, 1987).

95 Piehler, Remembering War the American Way, 132.

96 "Record of Proceedings of the Forty-Eight Meeting of the American Battle Monuments Commission," November 19, 1946, Box 1A, Proceedings Volume III, ABMC Records, NARA, p. 138.
} 
commemorative-zone assignments, General Vandergrift learned from a Navy survey that ninety-one percent of American families who had next-of-kin buried in the U.S. territory of Guam wanted their bodies returned to the continental United States. ${ }^{97}$ In the following ABMC meeting, that took place three months later, General Marshall served as the symbolic Chairman; not officially taking the title until Pershing's death. Marshall found that both General Eisenhower and General MacArthur desired only "one cemetery" in the Pacific Region. ${ }^{8}$ Hawaii was the most desirable location because it was symbolic of the whole Pacific War, was on American soil, and accessible to visitors. 99 Guam was the second choice because it was American soil, but it was inaccessible. The least desirable choice in the Pacific was at Manila in the Philippines, because it was now foreign soil and considered a politically unstable country. ${ }^{100}$ General Marshall respected the opinion of the decorated generals, yet he stressed to the ABMC commissioners the important psychological effect that American cemeteries, or as he called them, "permanent evidence of American sacrifice," had on foreign countries.101 Marshall seemed particularly concerned with reminding the Filipinos of the now positive relationship between the United States and its former colony. He did not want the apparent "inaccessibility" of the Philippines to deter placing a cemetery there because the dead could bind the nations together in the future.

Marshall found inaccessibility to be a disingenuous excuse for bringing remains home, and he also planned to sponsor legislation for a new class of Gold Star Mother Pilgrimages. Too many times in his military career had he seen unattended burials of

\footnotetext{
97 Ibid.,139.

98 Ibid., 143.

99 Ibid.

100 Ibid.

${ }^{101}$ Ibid., 144.
} 
American soldiers returned home from overseas combat because of their family's fear that no one would visit the grave abroad. ${ }^{102}$ At the end of the Pacific discussion, it was determined that all three proposed cemeteries remain in contention until it was settled how many bodies needed permanent interment following next-of-kin decisions. ${ }^{103}$ Much of the reason for keeping three cemeteries on the table instead of only one likely came from General Vandergrift's desire that a cemetery be placed on each Pacific Island where our men fought and fell."104 This was an infeasible desire, but paralleled with rivalry between attention to the Pacific and Atlantic theaters during the war. Bitterness among different branches of the military and theaters of operation was also prevalent in this era of defense reorganization and unification of military commands.

Ultimately, the only official ABMC cemetery to hold WWII remains was the Commission's third choice, the Philippines. The U.S. Army erected a large cemetery at the Punch Bowl in Hawaii, but the Veterans Administration, not the ABMC, oversaw it. Within the Punch Bowl cemetery, the ABMC did commemorate all of the missing from the Pacific Theater on Walls of the Missing on a Pacific Memorial. ${ }^{105}$ Historical evidence suggests that the primary reason for not burying Americans permanently on Japanese soil was based on WWI precedents to avoid enemy soil, and because of the inaccessibility of Japanese islands. ABMC Secretary Thomas North reported that the ABMC felt that the upkeep of even memorials on isolated islands like Iwo Jima was

\footnotetext{
102 Ibid.

103 Ibid.

104 General Vandergrift, "Report of Pacific Area Committee," January 3, 1947 included within "Record of Proceedings of the Forty-Ninth Meeting of the American Battle Monuments Commission," February 13, 1947, Box 1A, Proceedings Volume III, ABMC Records, NARA, p. 143.

105 This memorial has expanded to include the missing of Korea, and Vietnam, along with battle maps of WWII, Korea, and Vietnam.
} 
unfeasible. ${ }^{106}$ Cemeteries would prove nearly impossible to maintain at the rigorous standards that the ABMC strove for. The ABMC attempted to acquire funding for a memorial on Okinawa in 1960 only to be rejected by the State Department because "Japan retained residual sovereignty over the island," making an American memorial there inappropriate. ${ }^{107}$ North personally resented this decision because when the United States occupied the island briefly after the war it allowed the Japanese to erect some two-hundred unit memorials. ${ }^{108}$ This personal dissatisfaction from North seems to be the only remnant of cultural animosity towards the Japanese present in the ABMC's historical records. North's comment was minor considering the conduct of the war.

\footnotetext{
${ }^{106}$ North, One Soldier, IX 6. 107 Ibid., IX 14. 108 Ibid.
} 


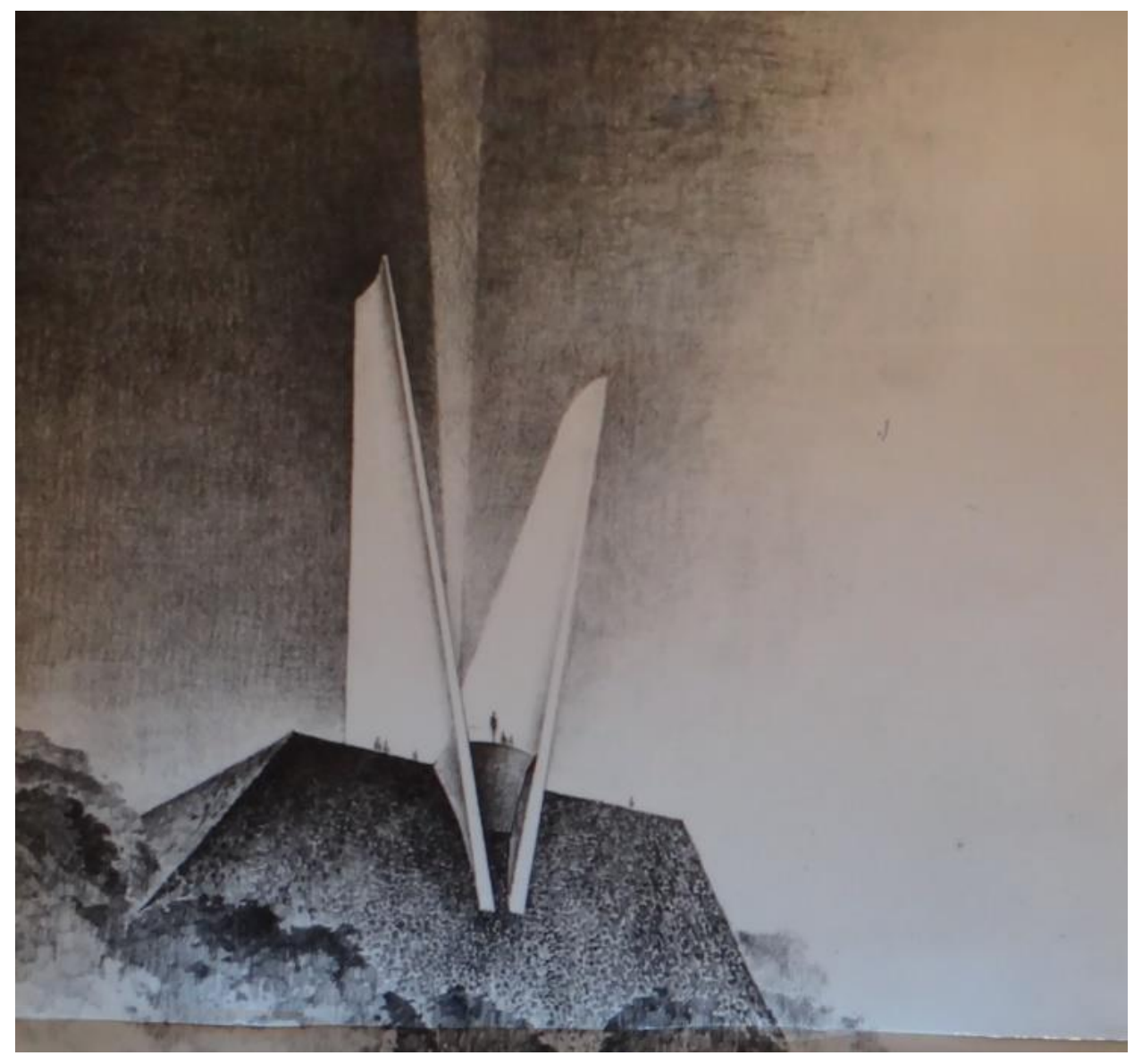

Photo 4.2: Proposed Okinawa Memorial. Source: RG 66 Commission of Fine Arts, Box 17, Entry $7 A, N A R A$.

\section{The Dishonorable Dead of Plot E}

Thus far, this chapter has shown how the ABMC functioned during World War II and started expanding its commemorative scope at the earliest points of the Cold War. The fundamental argument of this entire work is that a specific, prideful memory of American military remains was implanted in Europe for political purposes. American memory implanted in European soil, up until this point, been the presentation of a positive memory to foreigners. Before moving into a detailed discussion of uses of 
American remains in Cold War Europe, it is useful to mention a negative memory of American remains hidden in France as an anti-memorial. Over one-hundred thousand American military remains rest in France as human relics for the living to hopefully learn from. In addition to the 100,000 positive memories are the remains of some 100 soldiers whose memory the American government has effectively erased from the public consciousness.

World War II is the "good war" in American memory. Americans who lived through the war have come to represent the nation's greatest generation. The World War II remains cared for by the ABMC physically represent this sacred memory. American soldier dead of this war in Europe, Italy, Belgium, the Netherlands, the Philippines, and North Africa offer foreigners a chance to engage with the best stock America produced. Historians have begun to dismantle some of the mystique of the "good war" in American memory. America's WWII generation, just like every other had its flaws. They argue that as a society, America should not only focus on only the positive elements of the WWII generation. The negatives must also receive attention. ${ }^{109}$ Americans can only find usable lessons from WWII if the uglier aspects of America's World War II experience are included in historical studies. Blindly glorifying World War II and romanticizing the era creates a commitment to militarism and misunderstanding of history. It also prevents Americans from critically looking at the way the world views their country-and America's role in the Cold War. The American soldiers who fought in World War II were human beings with flaws. They fought for a noble cause. Yet,

109 See Michael Adams, The Best War Ever: America and World War II (Baltimore: Johns Hopkins University Press, 1994), Kenneth Rose, Myth and the Greatest Generation: A Social History of Americans in World War II (New York: Routledge, 2008), and Gerald Linderman, The World Within War: America's Combat Experience in World War II (Cambridge: Harvard University Press, 1997). 
fighting for such a cause does not necessarily bestow sainthood on the warrior. Many American GI's cursed, gambled, smoked, drank, and were sexually promiscuous. The war they fought in was the true start of modern warfare. American military personnel died impersonal deaths brought by unseen enemies, their bodies mangled beyond recognition. Fear, combat fatigue, and shell-shock (then misdiagnosed as cowardice) were common. World War II soldiers fought in a fast-paced mobile war. In some theaters, particularly the Pacific, the brutality of the fighting was fueled by racism on both sides. It is unfathomable to think that the diversity of the World War II experiences of American soldiers, is captured in a single narrative or commemorative site. Yet, that is what the ABMC's sites of memory offer for both its World War I and World War II cemeteries. Only one ABMC cemetery contains a counter-narrative, but it is hidden from the public eye.

The ABMC's Oise-Aisne Cemetery, seventy miles to the east of Paris, commemorates 6,012 American World War I soldiers, however, it also holds an antimemorial to World War II. In Plot E, a burial plot hidden by shrubbery near the cemetery's entrance, rest ninety-six unnamed American World War II soldiers who were dishonorably discharged and executed during the war. These soldiers are concealed from view and inaccessible to the general public. No markers exist to draw attention to their resting places. Their headstones are not upright marble crosses, but inconspicuous flat stones bearing only a number. Little has been written about this site because hardly any archival evidence exists about the decision making process to establish dishonorable burial plot. The little knowledge that exists about the site came from family inquiries about burial records and Freedom of Information requests. Some of the most public attention to the site came from two of its remains. The remains of Emmett Till's father 
rest in Plot E, as did Eddie Slovik's (the only American soldier executed for desertion since the Civil War). ${ }^{110}$

This site shows the selectivity from the American government about what kind of remains it desired to present to the public. Plot E also demystifies the World War II generation. The ninety-six remains in Plot $\mathrm{E}$ are almost all soldiers court-martialed for heinous crimes such as rape and murder. Once found guilty, the Army executed them either by hanging or firing squad. Before each of them died, they were stripped of their insignia and dishonorably discharged from the military. They died not as American soldiers, but violent criminals. This plot shows that not only the fallibility of American soldiers, but perhaps more importantly, flaws in U.S. society. Of the ninety-six remains, eighty are those of African Americans-meaning that 83\% of all American soldiers executed in World War II were black. ${ }^{111}$ The American remains in ABMC cemeteries from both World Wars are not distinguished by race, however, they fought in Jim Crow armies. It is almost certain that racial bias influenced the military tribunals, and punishment, of African American soldiers. The reason that these remains do not rest in the public portion of $\mathrm{ABMC}$ cemeteries likely has nothing to do with race, but Plot $\mathrm{E}$ itself is entirely about race.

One can only speculate about the reasoning behind Plot E's existence. Its location at a World War I cemetery, and not a World War II cemetery suggests that the

\footnotetext{
${ }_{110}$ Emmett Till was brutally murdered as a teenager in the Jim Crow south in the 1950s. Emmett Till's body was so badly mutilated that he was only identified by his fathers silver ring on one of his fingers. This was the same ring that Till's father wore during WWII, it was returned to his wife after the requested information on his death. He became a symbol of the Civil Rights Movement. Eddie Slovik's remains were eventually returned to the United States after an appeal to Ronald Reagan in 1987.

${ }^{111}$ Alice Kaplan, "A Hidden Memorial to the Worst Aspects of Our Jim Crow Army," The Chicago Tribune, September 25, 2005, online edition at http://articles.chicagotribune.com/2005-0925/news/0509250486 1 jim-crow-army-till-official-army, accessed March 13, 2014.
} 
Army did not want the undesirable remains associated with the soldiers of their own war. This perhaps signifies that the memory of World War I soldiers was already becoming less potent. One also wonders if Plot E was viewed as the Army's attempt to protect the families from dishonor, or a way to put the executions out of public memory? If this is the case, one wonders why the dishonorable remains were placed in such close proximity to a sacred American site? Perhaps the close proximity of the dishonorable corpses to a cemetery full of respected corpses was seen as the ultimate insult to their memory. Historians cannot write history based on hypotheticals. The lack of evidence means that Plot $\mathrm{E}$ will remain a mystery unless documents are released, or discovered in the future. The mere existence of Plot E is useful to the argument of this work, however. It shows that the government did not want certain remains to contribute to the American memory of its sacrifices for the world. Just as Soviet soil was a cancer in which American soldier dead could not rest, the dishonorable dead were a tumor that could not taint friendly soil. The presence of dishonorable remains threatened the sanctity of the discourse of the dead so meticulously constructed since 1918.

The purpose of this discussion of Oise-Aisne's Plot E is not to glorify American soldiers convicted of rape, murder, and desertion. Executing soldiers convicted of violent crimes was not new for the United States at the time of World War II. Execution was a common practice during the American Civil War, but much less frequent in subsequent wars-particularly for cases of desertion. "Military executions made a forceful statement about the need to be prepared to die" in battle and also scared troops from disobedient behavior. ${ }^{112}$ Military execution equated to the ultimate "bad death" for

112 Drew Faust, This Republic of Suffering: Death and the American Civil War (New York: Knopf Press, 2008) 27-29. 
many soldiers in previous U.S. conflicts. ${ }^{113}$ Soldiers sentenced to death not only lost their lives, but were killed in public display as a lesson to their comrades and brought shame to their families at home. The overwhelming percentage of African American soldiers in Plot E merits deeper questioning into the fairness of their trials and legitimacy of acquisitions against them. In a Jim Crow army, it is hardly conceivable that all of these executed men received the type of trial they would have if white. The current study is not the place to delve into such questions of legal racism, however. The lesson to be drawn from Plot $\mathrm{E}$ for this work is the selectivity that the government showed regarding what remains the public could interact with. The racist circumstances visible in the executions does not necessarily collate to racist motives for keeping the bodies from ABMC cemeteries. The ABMC did, after all, adopt desegregated burial practices. The bodies of Plot E more likely faced exclusion because they explicitly represented the worst elements of America's war effort. They died with the label of murderers and rapists. Such obvious bad memories had no place in the sacred fields created by Washington to implant specific imagery of the United States to others. Just as friendly soil was important to cemetery location, so were friendly remains. Surely, of the approximately 100,000 remains officially commemorated, there are stories that do not fit the official memory assigned to the mass of dead. The Cromwell twins in Suresnes who killed themselves due to combat fatigue is one obvious example. The likely difference between the remains in Plot $\mathrm{E}$ and other burials is that Plot E remains have memories that are verifiably negative. To this day, the public has no access to Plot E. It essentially stands as the ABMC's non-memorial to the World Wars. The

113 Ibid., 27. 
dishonorable dead represent remains with no discernable value among the thousands of their respected counterparts.

\section{$\underline{\text { Conclusion }}$}

The United States had an established system of commemoration on the European continent prior to the start of the Second World War. When this war began, American remains from the Great War stood out on the landscape as a means for U.S. diplomats to remind conquered France of its historic support for the nation. These American World War I remains demanded care even during the conflict. The French showed their commitment to the U.S. by maintaining American graves in the absence of the ABMC. Once the United States entered the war, a far larger number of U.S. dead joined their brethren from the First World War. The United States government found that its dead of World War I could entice the living to leave the new generation of American dead abroad. The scope of American dead in World War was significant in quantity and geographic location. Dead U.S. military personnel from World War II came to overshadow those of WWII and led to an expansion of the ABMC's commemorative mission. This commemorative expansion was reflective of the United States new role international politics. Final resting places for U.S. remains indicated locations on the globe that the United States viewed as vital interests. In the Cold War, the United States came to demand more from nations that housed its military dead than ever before. The discourse of the dead helped define America's vision of its future alliances and enemies. The World War era ended in 1945, but U.S. remains stayed abroad as reminders of 
sacrifice. For the remainder of the twentieth century their memory was called upon to address ever shifting international situations. The early Cold War marked a return the aggressive American memory abroad found in the 1920s. Instead of representing peace, American bodies from the World Wars reflected a militant stand against the spread of left-wing political radicalism. 


\title{
V. Guardians of Friendship: American Military Remains in Early Cold War France
}

\author{
"The dead cannot go home. They paid too great a price. And, we will not go \\ home until our friends here feel that our presence is no longer essential to their \\ security, when we can leave a land free of terrors, a land where the dignity of the \\ individual is supreme, where a feeling of good faith dominates life." ${ }^{1}$
}

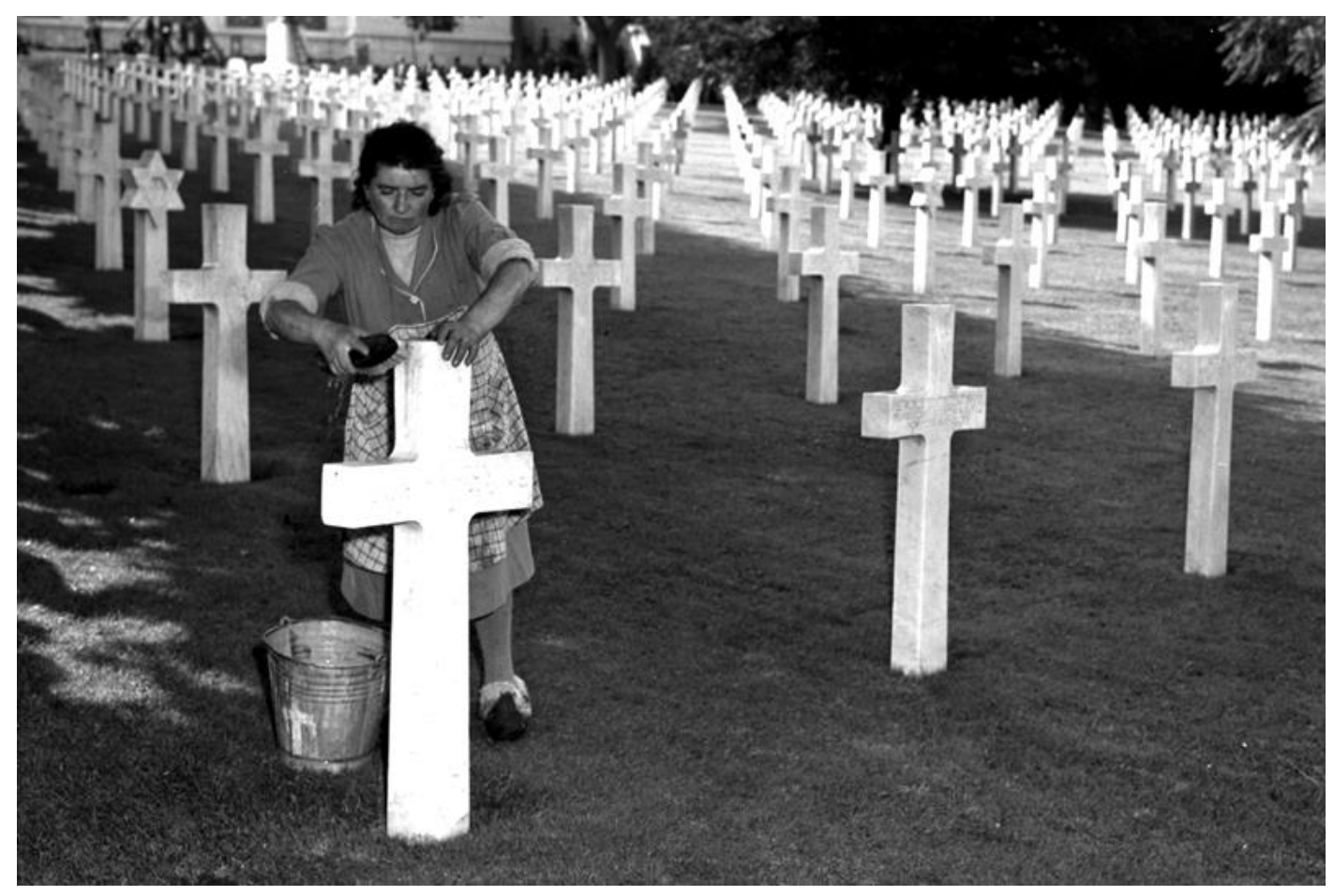

Photo 5.1: French woman cleaning American headstones at Suresnes American Cemetery. Source: "Marshall Assures Allies U.S. Will Remain Until Europe is Secure," Stars and Stripes, September 14, 1952. Photos by Red Grandy. Used with permission. (C) 1952, 2014 Stars and Stripes.

The Second World War left the United States and France in very different geopolitical circumstances. The United States emerged from the conflict one of the two world superpowers. France found itself a humiliated country struggling to find a usable

\footnotetext{
${ }^{1}$ George C. Marshall, "Dedication of Sursesnes Cemetery," September 13, 1952, Boxes 172 \& 174, Dedication Files, ABMC Records, RG 117, NARA.
} 
memory of the war that might allow it to rediscover national pride. Despite these different outcomes, both France and the United States found similar ways to engage with the memory of American war dead. Now backed by real international power, the United States chose to combat communism and the ideologies of the Soviet Union by casting the memories of its World War dead in France as cold warriors. France reverently turned to American dead, participated in memorial ceremonies, and created its own resistance memory alongside the victorious American memory. Thus, in early Cold War France, leaders in both France and the United States saw memories of American sacrifice as a means to proudly stand up to left-wing ideologies.

These high level uses of memory trickled down to the individual level. Edith Eustis visited her son Morton's grave at the ABMC's Normandy American Cemetery in Colleville-sur-Mer in late July 1952. She was wholly disappointed in her government's attempt at fulfilling its promise to provide a beautiful resting place for her boy. She took her complaint directly to the ABMC's prestigious new chairman, George C. Marshall. Mrs. Eustis wanted General Marshall to explain to her how in the eight years since peace there was no memorial building, no chapel, not a single map, only a lone flagpole, and no decent road. ${ }^{2}$ Other than a few marble crosses and the beginnings of a superintendent's house, she found the sacred site in worse condition than it was when she visited three years prior. ${ }^{3}$ As an American, not just a mourning mother, she found it "strongly disgraceful" and repulsive that the "richest country in the world has so neglected \& overlooked the soldiers who died for her." ${ }^{4}$ Mrs. Eustis traveled to an

\footnotetext{
${ }^{2}$ Mrs. Eustis to George Marshall, July 24, 1952, Box 161, Folder 6, Papers of George C. Marshall, ABMC File, George C. Marshall Library (hereafter GCML), Lexington, Va..

3 Ibid.

4 Ibid.
} 
English war cemetery for comparison and it made her son's resting place seem even worse. She found that although the British cemetery was not as ambitious and "rich looking" it was "quiet and lovely." 5 She knew that General Marshall could make no immediate improvement, but wished that he might get his Commission more motivated come autumn.

This type of letter was concerning to a man like General Marshall. Since his protégé General Pershing had died in 1948, the American Battle Monuments Commission was his responsibility. Marshall did not lead American WWII troops in battle, but as U.S. Army Chief-of-Staff, he organized their victory and was cognizant of the lives lost fulfilling his plans. Marshall personally responded to Mrs. Eustis informing her that he was travelling on behalf of the ABMC to inspect all cemeteries within the month. Normandy was his first stop. He assured her that "I shall have your reactions very much in mind when I visit it" and she should expect a letter of reply. ${ }^{6}$ Upon returning home, Marshall felt that the progress his Commission made was very satisfactory considering delays of Congressional funding in the early Cold War. He was so impressed with the sites that he compelled the ABMC to take more steps to "encourage travel to the various cemeteries." ${ }^{7}$ He wanted Americans to feel that their dead's "lasting resting place was not dreary, but beautiful and constantly visited by large numbers of people." He also felt that "it is to the advantage of our country to have as many foreigners as possible see this impressive testimony of sacrifice our men made on

\footnotetext{
5 Ibid.

${ }^{6}$ George Marshall to Mrs. Eustis, April 14, 1952, Box 161, Folder 6, Papers of George C. Marshall, ABMC File, GCML.

7 “Marshall's Memorandum to Commissioners after 1952 Inspection Trip," Box 161, Folder 8, Papers of George C. Marshall, ABMC File, GCML.
} 
their behalf." ${ }^{8}$ Both seemed equally important to Marshall. It was not enough for the cemeteries abroad to appeal to Americans, but they needed to instill in foreigners a sense of awe regarding America's selflessness. If many others shared in Mrs. Eustis's feelings about Normandy, the ABMC's mission would be a failure. Marshall fulfilled his promise and responded to the complaint after his return. He understood the mother's concern, but explained to Mrs. Eustis all of the improvements that the ABMC had made in the cemetery not visible to the lay visitor. He assured her that Normandy was scheduled to be completed by the next summer, it was "further advanced than almost any other cemetery," and promised her that that ABMC was "alive to the natural desire of relatives for completed cemeteries." ${ }^{\prime 9}$ He also informed her that British cemeteries looked so much more advanced because that nation did not give any of its citizens their dead back. ${ }^{10}$ Marshall's experience as Chief-of-Staff, Secretary of State, and Secretary of Defense made him a chairman with a strong grasp on foreign relations and projecting U.S. values abroad. In America's fight against communism every weapon in the arsenal needed utilization. The memory of his WWI comrades and WWII legions were such a weapon. Marshall's 1952 trip was more than an inspection tour. His participation in dedication ceremonies demonstrated the usefulness that memories of American War dead had in Cold War politics.

This chapter explains the continuation of the ABMC into the Cold War and the symbolic importance of its post WWII commemorative agenda. It does so by placing the ABMC's work in the context of Cold War diplomacy. Much of the memory assigned to

\footnotetext{
8 Ibid.

9 Marshall to Mrs. Eustis, Undated, Box 161, Folder 8, Papers of George C. Marshall, ABMC File, GCML. ${ }^{10}$ Ibid.
} 
U.S. war dead in France repeated the tropes of the interwar: sacrifice, commitment to freedom, and friendship. A more militant memory also emerged in the early phases of the Cold War, however. As the United States acclimated to its new superpower status, its dead in France from previous conflicts became combatants as much as ambassadors of memory. France also acclimated to a new American war memory on its soil. American memory on French soil simultaneously served as an avenue to forge a proud French memory and incentive to create a distinct, yet equal, French World War II memory. The commemorative rhetoric of French and American leaders in the post-war period cast the sacrifices of their current Cold War fighters in the same light as dead from the World Wars. While the remains reflected U.S. power, they simultaneously needed to impart feelings of amicability in an era of decaying Franco-American relations. French resentment towards the United States increased dramatically in the mid-twentieth century as France became increasingly reliant on American loans and defense. ${ }^{11}$ Though small, and scattered, the vocal American memory projecting from ABMC cemeteries served to constantly remind Europeans of their unsurmountable debts.

Militant Undertones in God's Acres

The ABMC did not have a strong American military presence in France following the Great War to associate with. Some 50,000 U.S. troops remained stationed

${ }^{11}$ Philippe Roger, The American Enemy: The History of French Anti-Americanism (Chicago: University of Chicago Press, 2005), 302-303. 
in France throughout the 1950s, however. ${ }^{12}$ The French engaged with the American military during the interwar primarily through interactions with memories of past conflict. In the first decades of the Cold War, however, the ABMC's memory of military dead partnered with real military power. More so than after the Great War, the ABMC embraced its military connections and adopted an aggressive styles of commemoration. The ABMC chose not to follow the same traditional styles of architecture and cemetery layouts that it did after World War I. No longer did American decision makers feel that it was necessary to erect public monuments that meshed with European sensibilities. The United States was not a minor international player, but a leader oriented towards the future. ${ }^{13}$ Commemorative aesthetics reflected this. The ABMC abandoned classic architecture and opted for a unique American style of "scrapped classicism." ${ }^{14}$ This style wedded the decorative and elitist neoclassical style with curved, unadorned, flowing lines of modern art.15 The United States no longer "struggled with a new role in international affairs" as it had following WWII. ${ }^{16}$ American cemeteries reflected a new sense of place in the world. Instead of square burial plots, American WWII cemeteries presented trapezoidal and circular plots. This made it difficult for visitors to locate an

\footnotetext{
12 Tim Kane, “Global U.S. Troop Deployment, 1950-2003," Center for Data Analysis Report \#04-11 on Nation Security and Defense, accessed at http://www.heritage.org/research/reports/2004/10/global-ustroop-deployment-1950-2003, on April 23, 2014.

${ }_{13}$ Ron Robin, Enclaves of Memory: The Rhetoric of American Political Architecture Abroad 190o-1965 (Princeton University Press, 1992), 132.

14 Robin, Enclaves, 116-117. Robin describes Paul Cret's notion of scrapped classicism developing in the late 1920 until his death in 1945. Cret believed that monuments should retain "imperious overtones of classicism" while avoiding facsimile of Athens and Rome. Essentially, Cret was an architect of comprise, meshing tradition with modernism. Some of his most noted works are the Folger Shakespeare Library, Federal Reserve Building, and Bethesda Naval Medical Center.

15 Robin, Enclaves, 115.

${ }^{16}$ Elizabeth Grossman, "Architecture for a Public Client: The Monuments and Chapels of the American Battle Monuments Commission," Journal of the Society of Architectural Historians (Vol. XLII, No. 2., May 1984), 119.
} 
individual WWII grave without the help of an "official" ABMC worker. ${ }^{17}$ The flow of WWII cemeteries also varied considerably. Visitors entered American WWI cemeteries and immediately confronted the burial area. To reach the commemorative chapel they had to walk through the individual losses to reach the imposing architecture. World War II commemorative plans did not follow this model. The ABMC chose not to erect any grand monuments for American WWII battles outside of American cemeteries. Instead, each cemetery would have its own monument within it, accompanied by battle maps. These forms of monumentation were the first things visitors encountered in WWII cemeteries. Instead of immediately confronting individual loss, visitors saw imagery of a powerful federal government. ${ }^{18}$ At their core, the ABMC's WWII cemeteries represented a "brave new world" led by the United States to foreign audiences. ${ }^{19}$ It was hoped that the new cemeteries showed that America was a unique, modern nation, with a government powerful enough to be involved in the everyday life of Americans. ${ }^{20}$

ABMC historical documents also reveal understanding that General Pershing's chairmanship established a strong military heritage that needed continuance. T. Bentley Mott, the ABMC's European officer through WWII; and the man who appealed to Pershing for the ABMC to be proactive so it might retain more bodies following WWII; provided an early vision of the ABMC's post-war position in Europe. Mott wrote to the ABMC's Washington headquarters in the final months of World War II to discuss whispers in the Paris embassy of the ABMC's eviction following the war. Mott saw this as an attack on General Pershing's favorite agency which for twenty-five years had

\footnotetext{
17 Robin, Enclaves, 124.

18 Ibid., 127.

19 Ibid., 124.

${ }^{20}$ Ibid.
} 
received nothing but the most "delicate consideration" from the American government. ${ }^{21}$ In Mott's opinion, Washington had yet to understand the significance the ABMC would have in military relations with Europe following WWII. Mott felt that after Pershing's death the "latest very famous general" would became the Chairman of the ABMC. ${ }^{22}$ This famous general would undoubtedly desire to continue the "Pershing tradition" working from the same office and desk that Pershing occupied. If the Paris embassy relocated the ABMC, the Commission would likely never get back the same office space. Parisians would inevitably "seek after" the new famous military leader of the ABMC, and only then would the Department of State understand its error in evicting him. ${ }^{23}$ Mott recommended that Chief-of Staff George Marshall lead the charge to keep Pershing's office intact. Mott's apprehension about moving the ABMC's offices showed the selfimportance that the ABMC assigned to itself moving forward in the post-war world. World War II commemoration was going to be a great undertaking, and the ABMC was going to retain a very public presence. A great American military leader from WWII combat would want to take the helm of the $\mathrm{ABMC}$ and assert himself on the European landscape.

Mott's prediction was only partially correct. Famous generals continued to lead the ABMC, but none maintained the presence in Europe that Pershing did. Mott's outlook reflected his experiences in the interwar years when a strong American military presence did not exist in Europe. The ABMC's chairman in the post-World War II era would not be as important as the ABMC's cemeteries themselves. The most powerful American military leaders in Europe were active duty and leading American collective

\footnotetext{
${ }^{21}$ Mott to Charles Shaw, April 23, 1945, Box 133, WWII Maintenance File, ABMC Records, RG 117, NARA. 22 Ibid.

23 Ibid.
} 
defense efforts. These serving generals, already on European soil, would be the new era's military face at ABMC sites. They would dedicate the monuments and make annual pilgrimages to military remains. The closer proximity of U.S. service members to ABMC cemeteries through the Cold War brought more of an official military presence to cemeteries than there was during the interwar. American troops stood readily available to serve ceremonial duties and close enough to tour the old battlefields and cemeteries. The practice of having a uniformed veteran at each cemetery to watch over the remains as a superintendent also continued. Each of administrators was to be an "American veterans, with special quarters on site at the cemetery." ${ }^{24}$ Symbolically, it was important for the agency to have a veteran overseeing the graves of military remains-a practice that continues today.

${ }^{24}$ North, One Soldier, II-14. 


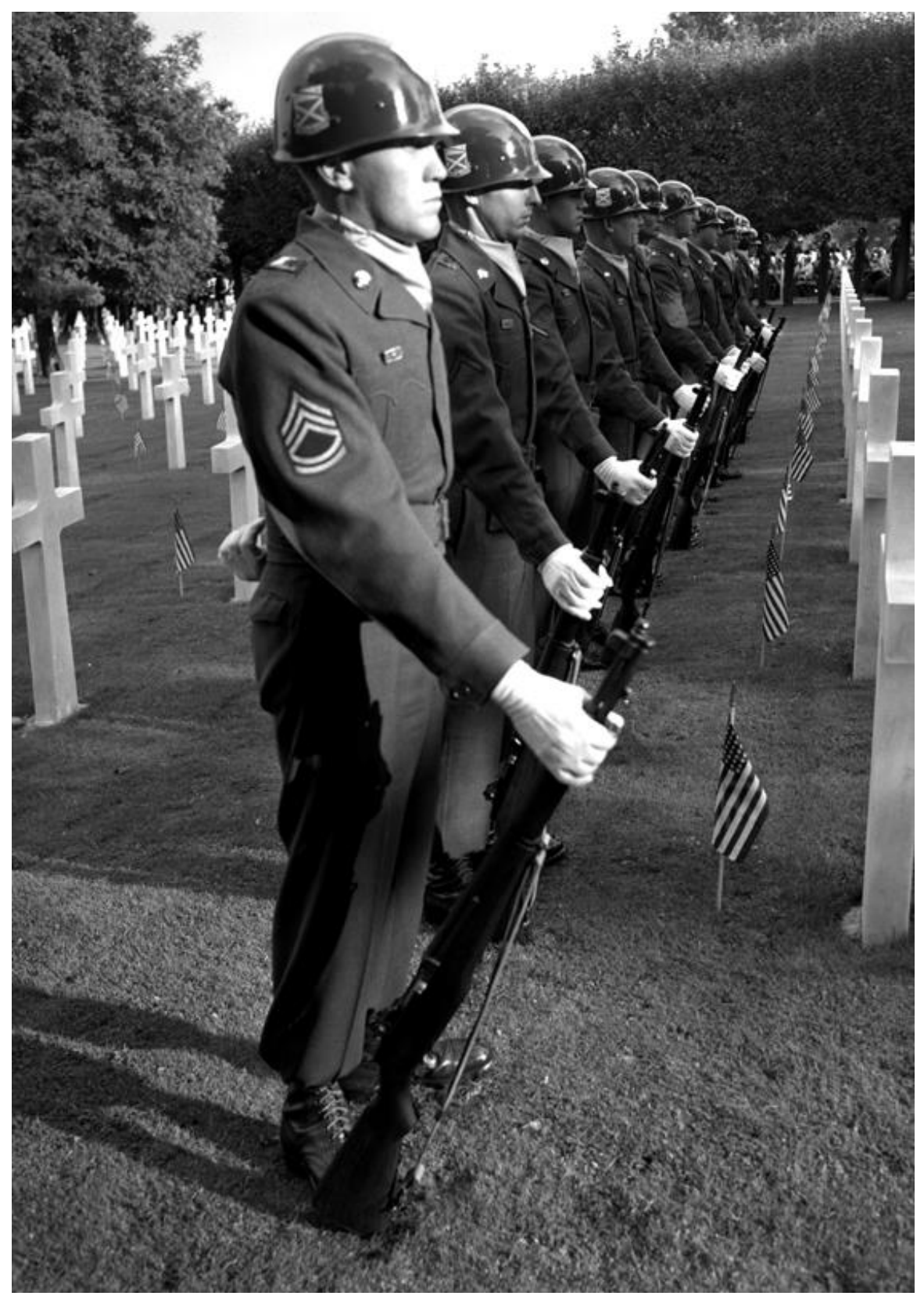

Photo 5.2: U.S. Soldiers in Suresnes American Cemetery. Source: "Marshall Assures Allies U.S. Will Remain Until Europe is Secure," Stars and Stripes, September 14, 1952. Photos by Red Grandy. Used with permission. (C) 1952, 2014 Stars and Stripes.

Despite the strong military component of the American Battle Monuments Commission, its leaders took efforts to distance cemeteries from active defense programs. Secretary Thomas North described a fight with Washington to keep ABMC 
cemeteries separated from military establishments. North wanted all American cemeteries from World War I and World War II to "maintain an unquestionable nonmilitary status. ${ }^{25}$ He provided specific examples of what this meant, and why the nonmilitary status was desired. Fear of a hot war with the Soviet Union in Europe was a real concern, as was the threat of nuclear attack. In case of emergency, Washington wanted to use a few of the ABMC sites for strategic purposes. It was hoped that "food, bedding, etc. which might be needed by other U.S. Government agencies be stored at cemeteries." ${ }^{26}$ Washington also wanted to install "radio and radar" equipment in some cemeteries for defense purposes. ${ }^{27}$ North never mentioned specific cemeteries or who pushed for the transformation of ABMC sites into military bases. The continual focus on Suresnes as an important ABMC site in France throughout various agency records makes it reasonable to believe that Suresnes was a desirous location for emergency materials. It also offered a large storage area under its chapel and close proximity to Paris and the French Defense Department. Through this "unsettled era," North fought to keep to keep the military out of ABMC sites. His main reason for this was the relationship France had with the cemeteries. Throughout the ABMC's history, even during German occupation of WWII, American military cemeteries remained virtually "immune from desecration and damage." ${ }^{28}$ North and other commissioners reasoned that part of the reason that these sites remained untargeted by protestors was because they did not possess advert military connotations. The sites needed to have a strong

\footnotetext{
25 Ibid., IX 8-9.

${ }^{26}$ Ibid.

27 Ibid.

${ }^{28}$ Ibid.
} 
military presence, but not a feeling of permanent military bases. They straddled the line between cultural products and military installations.

Will the French Fight? French Participation in American WWII Memory

The rhetoric of friendship between France and the United States continued through the early part of the twentieth century, despite the inability of both nations to see the future in the same light. The Franco-American partnership during the Cold War was at best a "cold alliance." 29 The United States tended to belittle French concerns and feminize the nation as over emotional, while France resented the historic dependence it had developed for U.S. assistance throughout the twentieth century. ${ }^{30}$ The fissure between the United States and France developed primarily because of France's humiliating defeat in World War II. France's rapid capitulation in the war proved to America that its ally was an ineffective nation morally, politically, and militarily. ${ }^{31}$ The French needed a means to rebuild their reputation when the war ended. This rehabilitation took many forms, but one was distancing the dishonorable past by participating in the victorious one. American dead served as an accessible point of entry into a victorious memory. By honoring the American dead, French who showed passivity during the war, might form memories of strong resistance.

General Charles de Gaulle, led the Free French movement, and emerged as the redeemer of France. He was a fervent French nationalists who saw a future where

\footnotetext{
${ }^{29}$ Frank Costigliola, France and the United States: The Cold Alliance Since World War II (New York: Twayne Publishers, 1992), 7. 3o Ibid.

${ }^{31}$ Castigliola, France and the U.S., 8.
} 
France stood as an equal partner of Washington, Moscow, and London. Throughout the war, de Gaulle struggled to gain recognition from the Allies. It was not until the approach of D-Day that Washington chose to recognize that de Gaulle would control liberated France. ${ }^{32}$ Much of this support came from de Gaulle's ability to rally communists and Gaullists under one banner. Communists showed a willingness to join de Gaulle knowing that Allies needed to win the war for them to have a voice in future French politics. ${ }^{33}$

De Gaulle's Free French forces offered a mixture of asset and liability in the European theater. Following D-Day, American forces struggled over a month in the Normandy hedgerows to push the Germans east. Once the Germans fell back, General Eisenhower desired to pursue as rapidly as possible. Fast pursuit meant postponing the liberation of Paris because it held no strategic purpose and would cost time and resources. De Gaulle insisted on liberating his capital and ordered his armies forward despite Eisenhower's wishes. Understanding the symbolic importance attached to the army liberating Paris, Eisenhower ordered American divisions to take the city and troops from both nations rushed ahead. On August 25, 1944, the main body of the French and American armies entered Paris. The first waves of Americans to liberate Paris on August 25, 1944 described the experience as one of the "greatest nights" of their lives. ${ }^{34}$ Everywhere, crowds gathered to shower them with affection and gifts. Wine, food, music, and sex came in abundance. ${ }^{35}$ The following day, de Gaulle "relit the flame

\footnotetext{
$3^{2}$ Harvey Levenstein, We'll Always Have Paris: American Tourists in France Since 1930 (Chicago: University of Chicago Press, 2004), 74.

33 Castigliola, France and the U.S., 29.

34 Levenstein, We'll Always Have Paris, 75.

35 Ibid., 75 .
} 
at the Tomb of the Unknown and led a victory march." ${ }^{36}$ In the days that followed, Eisenhower sent more of his divisions through Paris on their way to the battlefronts in the east at the request of de Gaulle. ${ }^{37}$ This showed American support for de Gaulle's leadership and might thwart communist attempts at a power seizure. ${ }^{38}$ Members of the American military represented a partnership through the initial stages of French liberation, but in the final year of WWII, and in the years after, hundreds of thousand GI's enveloped Paris and other French cities. American liberators eventually turned into the same asset and liability to the French that they were for America during the war. ${ }^{39}$ American arrogance and disregard for law annoyed the French, but their presence also provided a means for the French to forget the negative parts of their recent past.

${ }^{36}$ Castigliola, France and the United States, 34.

37 Levenstein, We'll Always Have Paris, 76.

${ }_{38}$ Castigliola, France and the United States, 34.

39 Levenstein, We'll Always Have Paris, 82. 


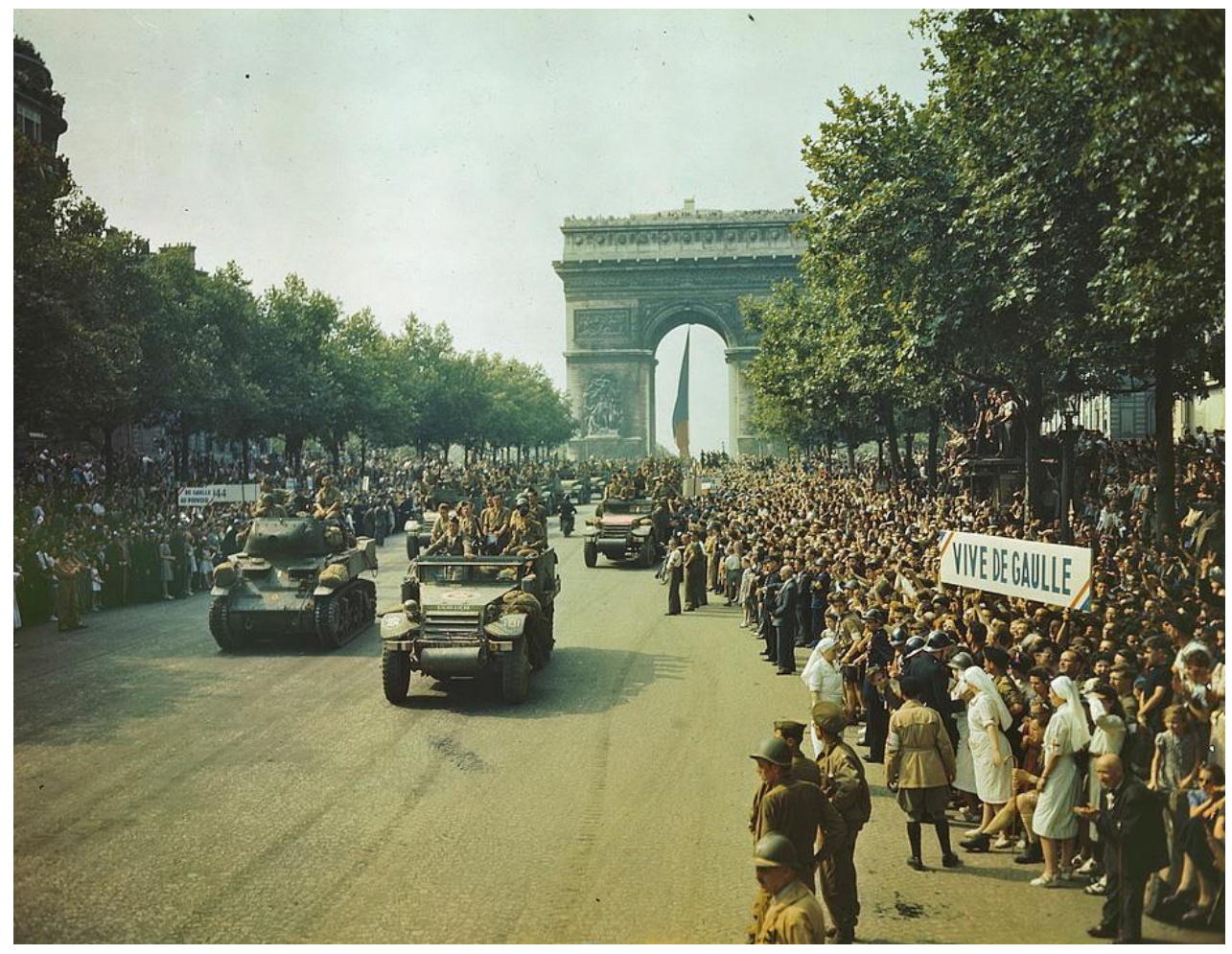

Photo 5.3: Crowds of French patriots line the Champs Elysees to view Allied tanks and half tracks pass through the Arc du Triomphe, after Paris was liberated on August 25, 1944. Source: Library of Congress. Image accessed from http://www.commandposts.com/2011/o8/august-1944-liberation-of-paris-inpictures/.

Many historical studies of the legacy of the Great War in France exist, while the historiography of France's immediate post-WWII period remain sparse. ${ }^{40}$ Much of the sparseness comes from the complexity of post-WWII France and the need for studies adopting multiple perspectives. Following the Great War, France had much mourning to do, but also a major victory to celebrate. This was not the case following WWII. In this conflict, France did once again side with the victors. However, the populous also needed to grapple with the overwhelming defeat of 1940 and a fractured population.

${ }^{40}$ Fabrice Grenard, "The French after 1945: Difficulties and Disappointments of an Immediate Post-War Period," in Lothar Kettenacker and Torsten Riotte eds., The Legacies of Two World Wars: European Societies in the Twentieth Century (New York: Berghahn Books, 2014), 204. 
Under de Gaulle's leadership immediately after WWII, France made efforts to move forward from its troubled past. Celebrating in liberation required Vichyites, Gaullists, Communists, expelled Jews, and other political factions to reach some form of memorial consensus. Efforts to purge France of former enemies took place in the immediate aftermath of the war, but never reached full potential. Around 350,000 French faced collaboration charges, three top French officials were executed, and out of 7,000 death sentences in French municipalities, 767 were carried out. Tens-of-thousands of lesser sentences from imprisonment, loss of employment, or public humiliations also took place. ${ }^{41}$ General de Gaulle hoped to form a collective French memory of a nation of resistors, not traitors. If truly all French that collaborated in some way with the Nazis were punished, the nation would have likely underwent a civil war and seen a crippling numbers of sentences. De Gaulle instead pushed for a more "moderate purge," despite cries from the communists to rid France of all Vichy remnants. ${ }^{42}$

A large part of France's rehabilitation centered on constructing a memory of the some 600,00o French dead that "rebuilt a national identity" from World War II. ${ }^{43}$ Between 1944 and 1950 French mourners inundated Paris with requests to erect memorials, construct cemeteries, and name streets to remember French citizens who died as resistors. While similar, French WWII memorial practices functioned quite differently than those of the Great War. French commemorations served as civic holidays that paid homage to the dead and celebrated peace more so than victory after World War I. ${ }^{44}$ The memory of resistance that formed after WWII was dissimilar.

\footnotetext{
${ }^{41}$ Grenard, "The French," 210. A common punishment for French women who had sexual relations with occupying Germans, "horizontal collaboration," was to shame them by publicly shaving their heads.

42 Ibid., 209.

43 Ibid., 207.

44 Ibid.
} 
Memories of the dead focused on their role in resisting and placed "greater emphasis on victory" to rebuild a prideful national identity through "patriotic euphoria." ${ }^{45}$ This is a fascinating transition considering that France's role in victory during WWI was far greater than during WWII. The French went to great lengths to remember themselves as active resistors despite the existence of stronger remnants of collaboration. America and Great Britain helped promulgate this message to a certain extent. They hoped that a victorious French image might help de Gaulle control French communists. General Eisenhower did not go out of his way to downplay the French role in their own liberation. Instead, he gave the French resistance room to assert its legitimacy. He allowed French General Leclerc's French troops to first enter Paris, and publicly estimated that French resistors contributed the equivalent of fifteen army divisions to the liberation battles. ${ }^{46}$ At a ceremony at the Arc de Triomphe in September 1944, General Eisenhower told his audience that "the French had the largest share of the glory having liberated the capital of their country." 47 Additionally, U.S. propaganda posters in 1944 France did not depict Americans as saviors of a passive France, but often included images of American, French, and British fighters side-by-side. ${ }^{48}$

French reverence to American dead into the national effort aided in efforts to create a prideful memory. Many French chose not to risk their lives engaging in resistance during German occupation, but after the allied invasion many opportunities arose for French to associate themselves with the resistance movement, no matter how

\footnotetext{
45 Ibid.

${ }^{46}$ Simon Kitson, "Creating a Nation of Resisters? Improving French Self-Image, 1944-46. In Monica Riera and Gavin Schaffer eds., The Lasting War: Society and Identity in Britain, France, and Germany After 1945, (New York: Palgrave MacMillan, 2008) 72-73.

47"General Eisenhower Salutes Paris," L'Humanité, September 9, 1944, from National Library of France online database.

${ }^{48}$ Kitson, "Creating a Nation of Resisters," 73.
} 
insignificant the contribution. One of the most accessible ways for the French to feel like a part of the resistance was through participation in ceremonies. "Taking part in celebrations and subsequent commemorations helped root citizens firmly in the Allied/Resistance camps and gave them a sense of having participated in a small way to Liberation." ${ }^{\prime 9}$ By participating in victory celebrations, it was possible for a French citizen to erase years of passivity and form a memory of themselves as a resistor.

The thousands of American corpses present in France provided easy access to a prideful memory. Participation in the commemoration of American military dead became just as viable a means for the French to create a positive memory associated with victory as commemorating their own dead. Throughout WWII, the French had thousands of American military dead from WWI to pay respects to in addition to the newly deceased American soldiers from WWII. American newspapers immediately following French liberation revealed a population eager to engage with American soldier dead. The byline of the Chicago Tribune's report on 1945 Memorial Day ceremonies abroad was "Europe to Bow to Yank Dead." ${ }^{50}$ It reported that "French children would bring wildflowers to Americans graves" and that some Parisian children even did this throughout German occupation. ${ }^{51}$ General de Gaulle furnished a French honor guard to join this youthful image of French resistance ${ }^{52}$ The previous chapter of this work demonstrated how some French stood up to Vichy rule by maintaining ABMC cemeteries. Many of those French who resisted German occupation by caring for American soldier dead received commendation for their loyalty to the United States.

\footnotetext{
49 Ibid., 78.

$5^{\circ}$ Larry Rue, "Europe to Bow to Yank Dead Memorial Day," The Chicago Tribune May 17, 1945 inProquest Historical Newspapers.

${ }^{51}$ Ibid..

$5^{2}$ Ibid.
} 
Chairman George Marshall went out of his way in a 1952 inspection tour of U.S. cemeteries to acknowledge French caretakers. On this visit it was important to for Marshall to single out loyal ABMC employees who "with laudable devotion did their utmost to care for the World War I cemeteries and monuments during German occupation." ${ }^{53}$ As a sign of appreciation, Marshall pinned eleven French and Belgian ABMC employees with a special "Army Medal of Freedom Award” with the French Government's Veterans Minister in attendance. ${ }^{54}$ The recipients were blue collar workers, and the acknowledgement was surely important to them. When General Marshall learned that one of the ABMC's first employees, Andree Champagant, "was desperately ill in her apartment" and unable to attend the event, he insisted on making a personal visit to her Paris apartment and was willing to walk up six flights of stairs because it was "a matter of morale." ${ }^{55}$ This positive diplomatic gesture was made possible through memory and commemoration.

France and the United States also found in the dead a rhetorical channel to articulate French resistance. In a Memorial Day ceremony at Suresnes in 1947, French Prime Minister Paul Ramadier linked American WWI sacrifice to WWII praising them for realizing that "if France disappeared under a conqueror's yoke, the cause of liberty itself would be compromised." ${ }^{56}$ This demonstrated the formulation of a memory placing France at the heart of the allied cause-American military dead stood as proof of this understanding. France was the centerpiece of modern freedom. Later the same day American Ambassador Jefferson Caffery addressed a crowd of Frenchmen gathered at

\footnotetext{
53 North, One Soldier, II-18.

54 Ibid.

55 Ibid.

56 "U.S. Dead of 2 Wars Honored in France," The New York Times, May 31, 1947 in Proquest Historical Newspapers.
} 
temporary American WWII cemetery and strengthened the French resistance memory. Caffery told the audience that the American remains from the fight to liberate Paris "were not alone," but died with members of the French armies and French resistance, "who worked in darkness and too often died in darkness." ${ }^{57}$ Caffery gave the French a prideful memory of their part in liberation. American dead covered the French landscape, but Caffery acknowledged that many French died for liberation in less celebrated terms. Letting the French associate American sacrifice with their own helped ensure that the United States had a stronger ally in the future.

France heralded the memory of American dead, but also took steps to assert a distinct memory of their own dead alongside Americans. Allowing France to share in their liberation had the strategic value of helping de Gaulle establish power and get his country functioning again. It also opened-the door to French delusion as well. Some segments of French society actually came to remember their liberation as "almost exclusively French" quickly after the war ended. $5^{8}$ The memory of French and American war dead converged in a unique, if not combative way, at Fort Mont-Valérien.

Fort Mont-Valérien has thus far been a location frequently discussed in this work. On the outskirts of its defensive walls sits the American Military Cemetery at Suresnes. The fort's location on the highest ground around Paris made it a strategic asset to the Nazis during occupation. It also became a favored location for the Reich to imprison and execute French resistors. Between 1940 and 1944, over 1,00o French resistors died by German firing squad within earshot of the American World War I cemetery. The violence associated with Mont-Valérien made it an excellent location for General de

57 Ibid.

${ }^{8}$ Kitson, "Creating a Nation of Resistors," 72. 
Gaulle to perpetuate the resistance memory that he so wanted for France. On

November 11, 1944, de Gaulle visited the site and ordered it be set aside as a

commemorative location. He returned the following year on June 18, the anniversary of his famous radio address delivered to France from London, to light an eternal flame in memory of resistors.59 That same November, the bodies of fifteen French "combatants who had served in various branches of the armed forces and theaters of war were solemnly buried in a crypt" constructed at Fort Mont-Valérien by order of de Gaulle.60 The bodies stopped at the Arc de Triomphe en route to their final resting place at Suresnes. There, de Gaulle spoke to the dead and appealed for them "to heal the hurt France." 61 The selection of the fifteen remains revealed the specialized kind of memory de Gaulle sought. None of the bodies included were held or executed in Fort MontValérien. Instead, the 'resistors' were regular soldiers and Gaullists. ${ }^{62}$ This selective remembering ostracized a large portion of France, including communist resistors and those who lost family to the executions. After de Gaulle left office in 1946, government support for the memorial ceremony dwindled. French leaders still laid wreaths annually, but the memorial underwent no expansions and the ceremonies never approached the level of de Gaulle's. ${ }^{63}$ It was not until de Gaulle returned to power in 1958 that a commemorative focus returned to Mont-Valérien. The parking area was expanded and a sixteenth body from the Indochina war joined the original fifteen in

\footnotetext{
59 "Le Mont-Valérien," at http://www.mont-valerien.fr/comprendre/le-memorial-de-la-francecombattante/la-volonte-du-general-de-gaulle-1946-1960/, accessed July 24, 2014.

6o Nathan Bracher, "Remembering the French Resistance: Ethics and Poetics of the Epic," History and Memory, Vol. 19, No. 1, (Spring/Summer 2007), 54-55.

61 "The Willingness of General de Gaulle," at http://www.mont-valerien.fr/comprendre/le-memorial-dela-france-combattante/la-volonte-du-general-de-gaulle-1946-1960/, accessed July 24, 2014.

62 Bracher, "Remembering the French Resistance," History and Memory, 54-55.

${ }_{63}$ "The Willingness of General de Gaulle," http://www.mont-valerien.fr/comprendre/le-memorial-de-lafrance-combattante/la-volonte-du-general-de-gaulle-1946-1960/, accessed July 24, 2014.
} 
1960. The lull in commemoration following De Gaulle's first presidency showed that its transformation into a Gaullist site of French resistance memory caused divisiveness in French society. It did provide France a World War II counterpart for the Tomb of the Unknown at the Arc de Triomphe, however. It also asserted a French site of memory almost directly beside the American one at Suresnes. Perhaps this was a way for France to further advance a memory of equal partnership in the Second World War.

Seemingly not wishing let French WWII memory overshadow the American memory on Mont-Valérien, the ABMC took steps to transform the Suresnes cemetery into its own WWII shrine. Suresnes served as the ABMC's bridge of World War I and World War II memory. The architectural style of the ABMC's WWII cemeteries was more aggressive than in its WWI program, but that did not mean that there was a strong desire to completely separate the two conflicts in public memory. Initially, the Commission considered merely including American WWII dead in the WWI cemeteries already present in Europe. ${ }^{64}$ This would save money by not requiring the creation of new cemeteries from nothing. The plan to combine cemeteries failed because virtually no free space remained in American cemeteries from the Great War. ${ }^{65}$ The ABMC's WWI jewel, Suresnes, proved to be the only cemetery that was adapted to commemorate dead from both wars. Commissioners realized that Suresnes was the cemetery where "senior representatives of the French and American governments assembled on Memorial Day and other appropriate occasions to render homage to the American Dead.” ${ }^{66}$ It was not feasible to ask France for another large American cemetery in Paris; finding a site as pristine as Suresnes would be difficult anyway. It was also unacceptable

64 North, One Soldier, II-14-15.

65 Ibid.

${ }^{66}$ Ibid. 
for America to not have a cemetery to WWII in Paris where high officials could easily meet to commemorate both wars.

Suresnes thus became sort of a problem and exception for ABMC commissioners. The Commission decided that the World War I chapel within the Suresnes cemetery could easily evolve into a shrine to both wars by simply adding another wing and etching the names of WWII unknowns on a memorial wall. Apparently, a new chapel and etched names failed to make Suresnes truly representative of both wars and relevant in the new era. To ensure that the public viewed the cemetery as one of both wars, it needed bodies of both wars. The ABMC fulfilled this need by reconfiguring the WWI burial plots to inter twenty-four American unknowns from WWII. The plot of WWII unknowns was set-off from the others in the configuration of a crucifix. ${ }^{67}$ Disinterment of American unknowns in other parts of France for reburial in Suresnes demonstrated both the importance of Suresnes as a commemorative grandstand and the need of remains to legitimize the space. The pliability of memory assigned to unknown corpses also made them the most desirable remains from World War II to go into the ground at Suresnes. American Ambassador James Dunn told the audience the significance of unknowns at Suresnes during the re-dedication of the cemetery. Suresnes was symbolic of "all American overseas memorials to all America's sons who sacrificed." ${ }^{68}$ Unknowns went into Suresnes because "their fight was not a personal one," because death as an unknown meant loss of individual memory. The twenty-four American unknowns going into Suresnes represented an infinite number of stories. But, under the ABMC's care, they represented not fighters for America, or France, or Europe, but "for that

\footnotetext{
67 Ibid.

68 "Remarks of Ambassador Dunn," September 13, 1952, Boxes 171 and 174, Suresnes Dedication File, ABM Records, RG 117, NARA.
} 
impersonal-and reverend-right of mankind to be free." "They gave their lives for our common cause of freedom," Ambassador Dunn told the audience. ${ }^{69}$ This logic mirrored the selection of unknown soldiers to rest in the Tomb of the Unknown at Arlington National Cemetery. ${ }^{70}$ The appeal of the unknown was that the corpse might belong to any American who never received final closure. In reality, the remains might have represented any ethnicity, religious creed, or background. Their symbolic transfer to national shrines made them the property of collective American memory, however.

Little evidence about the decision making process to turn Suresnes into a dualpurpose WWI/WWII cemetery is available outside the Secretary Thomas North's manuscript and the dedication program. The ABMC's expansion of Suresnes and placement of WWII unknowns within the cemetery made it one of the most calculated cemeteries of the ABMC. In some ways, the commemorative steps taken by the United States and France on Mont-Valérien foreshadowed tensions to come. There was not a dialogue between the ABMC and French Ministry of Defense about their use of WWII remains on the high ground overlooking Paris. The actions of the two governments unfolded like a sort of memory-arms-race, however. General de Gaulle used carefully selected corpses to craft a French memory of WWII that made the conquered nation seem equal with other allies. This memory entered a landscape where American bodies had long reminded France of its sacrifice for a friend. With a powerful French WWII memory present on its borders, the ABMC needed to bring new bodies to Suresnes to redefine its own memory on Mont-Valérien. This duel of memories hinted at FrancoAmerican clashes to come as the Cold War intensified. The memory that de Gaulle

69 Ibid.

70 Michael Sledge, Soldier Dead (New York: Columbia University Press, 2005), 201-211. 
inserted on Mont-Valérien, very much reflected the political outlook he brought back to the presidency in 1958. France was a proud nation of resistors equal to the United States.

French attempts to assert a resistance memory in the early stages of the Cold War did not seem to drastically affect U.S. memory practices. French inclusion in the commemoration of American military dead was mutually beneficial to France and the United States. While it strengthened the resistance memory in France, it also forwarded the goal of the American government to keep U.S. military remains abroad. A battle for remains after WWII never reached the level of hostility in the United States that it did following the Great War. Much of this was likely attributed to the clear precedent set by the first generation of the American Battle Monuments Commission. It was also attributable to the overwhelming continuation for French reverence for American military dead. In the summer of 1947, the wife of Brigadier General Theodore Roosevelt returned home from a visit to her husband's grave in Normandy and reported upon leaving her airplane at La Guardia Airport in New York of being "deeply impressed" that the "French people want very strongly to have our dead left there." ${ }^{" 11}$ She was sure that if Americans saw these cemeteries and the French care "the program to remove bodies would be completely dropped." 72 President Truman made a similar plea to mourning American families to travel abroad in 1947 and view permanent WWI cemeteries and temporary WWII cemeteries. He "felt sure" that "if they could see for themselves the care devoted to the graves" they "would prefer that their loved ones rest forever in the

\footnotetext{
71 "Lauds French Care of U.S Cemeteries," The New York Times, September 231947 in Proquest Historical Newspapers. ${ }^{72}$ Ibid.
} 
countries where they fell." ${ }^{73}$ The ABMC realized quite quickly into its WWII commemorative work the necessity of tactful thinking. The French could find pride in American military memories on the European continent, but also resentment. Early attempts to repair the destroyed American WWI naval monument in Brest met with protest from the mayor. Brest suffered considerable damage during the war and the mayor advised the ABMC that it should "defer reconstruction of the monument until the people's homes had been rebuilt and the city's own war memorial erected," or else it risked "psychologically" damaging the American reputation in Brest. ${ }^{74}$ The ABMC understood the mayor's logic through its own experiences. It faced protest from the local population when trying to repair the monument prior to Brest's own recovery. In the earliest stages of repair "communists became agitated and the American flag was twice torn down from the flagstaff." ${ }^{75}$ It was not until the city was rebuilt and "the authority of its government became stable" that an official invitation to rebuild the monument came. ${ }^{76}$

The bonds between the United States and France through American dead were not enough to ensure a happy relationship between the two nations as the Cold War intensified. The Korean War and more aggressive U.S. foreign policy put France into a defensive mode, and through the 1950 s animosities grew between the longtime allies. One of the biggest questions leaders in Washington had about France in the early Cold

73 "Truman Urges Visits to GI Graves Abroad," The New York Times, May 14, 1947 in Proquest Historical Newspapers.

74 North, One Soldier, II-17.

75 Ibid.

${ }^{76}$ Ibid. 
War was, in the event of Soviet aggression in Western Europe, "will the French fight?"77 William Avery Crawford, a State Department official involved with the Office of Research and Analysis reported to Ambassador David Bruce in the summer of 1950 that a "deep and basic longing to stay out of war" existed in "Frenchmen of all degrees."78 If war came to Europe in the summer of 1950, Crawford envisioned France "throwing in the sponge rather than fighting." 79 But, if the United States provided a "truly serious plan for European defenses," the confidence and fighting spirit of the French might be restored. ${ }^{80}$ A similar letter from the American Embassy in Paris to the Assistant Secretary of European Affairs at the State Department concluded that the "French are tired, discouraged, skeptical, badly governed, and with a big Communist problem." ${ }^{11}$ Officials at the American Embassy felt the only remedy to the French malaise was initiating a complete "psychological transformation," a task that had no clear formula. ${ }^{82}$ Part of the transformation needed to come from a decisive military plan from Washington, but much of the effort to transform the French psychology in the subsequent years stemmed from more subversive "cultural projects." ${ }^{83}$

A memorandum between officers of the State Department's cultural relations division the following year revealed the emerging importance that the State Department

\footnotetext{
77 Unsigned letter to J.C.H. Bonbright Deputy Assistant Secretary for European Affairs Department of State Washington, DC, July 31, 1950, Box 5, Entry 2462, Paris Embassy 1936-55, Consulate Records, RG 84, NARA.

78 William A. Crawford to American Ambassador to France, "French Attitude in a National Emergency," July 26, 1950, Box 5, Entry 2462, Paris Embassy 1936-55, Consulate Records, RG 84, NARA, pp. 1-2. 79 Ibid.

80 Ibid.

${ }^{81}$ Unsigned letter to J.C.H. Bonbright Deputy Assistant Secretary for European Affairs Department of State Washington, DC, July 31, 1950, Box 5, Entry 2462, Paris Embassy 1936-55, Consular Records, RG 84, NARA.

82 Ibid.

83 W.R. Tyler to Elinor Teams, "Certain Aspects of the Role of Cultural Activities in the Cold War," State Department Memorandum, September 10, 1951, Box 5, Entry 2462, Paris Embassy 1936-55, Consulate Records, RG 84, NARA.
} 
placed on cultural exchanges. The report argued that "contrary to what many think, cultural projects can have tactical value in the cold war." ${ }^{84}$ For American culture to effectively transform the French, careful planning was necessary. American cultural transfers could not "be massive" because the volume of cultural effort did not impress the French, "quality and integrity" did..$^{85}$ According to the officers, one of the most important components of American culture to spread into France was art. "Good music will be applauded. Good painting and sculpture will be admired. But not because they are American, but because they are good." ${ }^{86}$ France hated propaganda and "abhorred it when it was disguised in art form." ${ }^{87}$ For American culture to positively influence the French, it needed to organically depict "social truth," and not reflect a state sponsored attempt to force "democratic art" upon them. ${ }^{88}$ The State Department's role in cultural transfer was ideally providing support to artists and boosting cultural products while "remaining behind the scenes as much as possible." ${ }^{\circ 9}$ The primary conclusion of the memorandum was that "the appeal of art wilts when the Government interposes itself between the audience and the artist." 90

This early Cold War memorandum rises many questions about the ABMC's role in State Department cultural transfer programs. No clear linkages exist in State Department records between the ABMC's commemorative plans and the Department's cultural transfer agenda. William Delano, the architect responsible for the WWII monument at Suresnes reflected in a letter to ABMC Chairman George Marshall that his

\footnotetext{
84 Ibid.

85 Ibid.

86 Ibid.

87 Ibid.

88 Ibid.

89 Ibid.

90 Ibid.
} 
work went beyond commemoration. Delano complained to Marshall for not mentioning his name at any point in the official dedication of his monument. He believed that his work not only showed America's sacrifices, but also its "cultural and industrial achievements." ${ }^{\text {91 }}$ It was clear to Delano that the ABMC's work was meant to achieve this goal, but its failure to publicly praise American artists hindered this meaning. It is highly unlikely that the State Department asked the ABMC to not mention artists so that the monument might seem less like cultural propaganda. But, the fact that dedication speeches focused more on the dead than cultural objectives did show how ABMC sites might implant American culture onto French soil more subversively.

If the State Department's assessment that the French hated democratic art was true, the ABMC's work should have been a totally failed to connect with the French. The ABMC was an American government agency and it clearly stood between the artist and the European public. If a French citizen wanted to find a blatant example of American democratic art, they needed only to visit an ABMC cemetery. By all accounts, the French should have abhorred ABMC sites, but they regularly attended ceremonies and cared for graves. The clearest explanation for French acceptance of ABMC sites is the presence of American military remains at these sites. Military remains elevated the sites from mere representations of democratic art. ABMC sites did not primarily transfer art, but the memory of human sacrifice-evident by the actual bodies of war. American military cemeteries in France did not just serve as observable art, but places for the public to interact with. The French visiting ABMC cemeteries were not passive spectators, but active participants in perpetuating memories. Cemeteries of the

${ }_{91}$ William Delano to George Marshall, 22 November 1952, Box 161, Folder 7, George C. Marshall Papers, GCML. 
American Battle Monuments Commission put democratic art on full display, but remains provided a buffer between the public and the art. Because ABMC sites are primarily cemeteries, it is not enough for scholars to evaluate the effectiveness of ABMC sites as public diplomacy through pure aesthetic analysis.

The previous chapters on the interwar years demonstrated that even during heightened anti-Americanism in the 1920s, ABMC cemeteries escaped hostility. The same was true in the Cold War. An American historian addressing French antiAmericanism in 1952 after a prolonged stay in Paris pondered about what America needed to do in France to lessen negativity. He ultimately felt that forbearance was the best option..$^{92}$ The American reformist zeal and never ending drive to control the future did not offer a good solution to French anti-Americanism. The French hated Americans because of their incessant need to meddle. The author's conclusion in 1952, was that the U.S. needed to stop orienting itself so much toward the future and pushing France to change. France was a country oriented towards the past, and the best platform for the U.S. to improve French relations was engagement with the past. ${ }^{93}$ A young nation like the United States had few dual French-American memories of the past to share. ABMC cemeteries in France offered some of the few American sites on the French landscape that offered the French a clear vision of America's role in their national survival. This work has shown that ABMC sites also represented American hopes for future diplomatic bonds, but the orientation to the future moved through memory. The mask of memory at ABMC cemeteries helps explain why they remained usable locations in Cold War France.

92 Arnold M. Rose, “Anti-Americanism in France," The Antioch Review, Vol. 12, No. 4 (Winter, 1952), 483. 93 Ibid. 


\section{Yankee Go Home!: Memory as a Cold War Weapon}

On November 5, 1952, the day of General Eisenhower's landslide presidential election, he addressed the French people on their national radio network, even stepping out of his comfort zone to speak his opening paragraph in French. Eisenhower's address on Election Day left little doubt about the importance Washington placed on French support in the Cold War. Eisenhower's selection as president made the future of Franco-American relations look optimistic. He was the face of American victory in World War II, he dealt with de Gaulle's resistance force respectfully, and served as the first Supreme Allied Commander of NATO's command in Europe. Friendship was stressed throughout the president elect's address to France. He noted that the FrancoAmerican friendship was not new, but proven, and one that Americans learned about from an early age. He acknowledged that "friendship between nations was often ephemeral," but through many "vicissitudes, the affection between France and the United States has endured, unimpaired. ${ }^{94}$ Eisenhower did not hide the purpose of his message. The men and women of France needed to work with the United States and the rest of Western Europe to "build a strong shield against the manifest imperialistic ambition of [the] Soviet Union.” ${ }^{95}$ As former Supreme Allied Commander of NATO's European Command, Eisenhower maintained intimate knowledge of the Soviet shield America envisioned. Eisenhower warned the French that "difficult days lie ahead," but

\footnotetext{
94 President elect Dwight Eisenhower, "Text of Declaration to France," November 5, 1952, Box 7, Entry 2462, Paris Embassy 1936-55, Consulate Records, RG 84, NARA. 95 Ibid.
} 
he was comforted by the historic trend of France and America "living together effectively." ${ }^{96}$ It also pleased him that French allies possessed a "rare combination of heroism, intelligence, and culture." ${ }^{97}$ At the time of this address, Franco-American relations were not as harmonious as Ike reported. The year leading up to Ike's election had been turbulent. Discontent over American actions in the Korean conflict increased in France. French dissatisfaction physically manifested when General Matthew Ridgway took over as Eisenhower's replacement as Supreme Allied Commander of Europe. The United States partially controlled the damage by aggressively turning to American military dead from the World Wars to make favorable links with the war in Korea.

The start of the Korean War in June 1950 increased French frustrations with its American alliance. ${ }^{98}$ French dependence on the United States meant that their future rested in the outcome of the Korean conflict. France's most prominent newspaper, Le Monde saw Korea as justification for France to withdraw from NATO and maintain neutrality in the increasingly hot Cold War. ${ }^{99}$ France supported the United States in the early stages of the war for going to the aid of South Koreans and sent 1,000 of its own soldiers to aid in the United Nations security force. When North Korean and Chinese forces pushed Americans back into the South and forced a frantic evacuation at Hamhung, French support waned. MacArthur's vision of countering with nuclear weapons and a full invasion of China, made France fear entrapment in another world war. ${ }^{100}$ General Matthew Ridgway eventually replaced Douglas MacArthur as commander of all United Nation forces in Korea. Ridgway received credit for improving

\footnotetext{
${ }^{96}$ Ibid.

97 Ibid.

${ }_{98}$ Costigliola, France and the United States, 82.

99 Ibid.

${ }^{100}$ Ibid.
} 
the morale of U.S. troops in Korea after Chinese forces embarrassingly forced an American retreat back into South Korea. Under Ridgway's leadership, UN forces also regained footing in Korea, pushing communist forces into a stalemate and eventual armistice.

France intently followed events in Korea. The French Communist Party voiced the loudest discontent for America's battle to contain communism on the Korean peninsula. A U.S. State Department Intelligence Branch survey gauged the French opinion of America in 1953 to determine how much Franco-American relations had deteriorated since World War II. The survey sampled a diverse segment of the French population. In general, it found that the French approved many of the bigger Cold War programs initiated by the United States. Fifty-six percent of the French polled approved of "efforts to unify Western Europe," the same amount approved of "the Marshall Plan." ${ }^{101}$ On the other hand, half disapproved of the Korean War and forty-nine percent took issue with the conflicts in Indo-China. ${ }^{102}$ Despite the disapproval, most of those sampled felt that the United States was not entirely responsible for the war in Korea. Only fourteen percent felt that the United States was to blame for starting the conflict, while thirty-four percent blamed the Soviet Union and communists. Nearly half of those sampled did not know who was at fault for the fighting in Korea. ${ }^{103}$ The key issue that the French had with the Korea War was America's conduct. Seventy-one percent of the sample heard that the United States used germ-warfare against North Koreans and

\footnotetext{
${ }^{101}$ Report on Foreign Public Opinion: French Attitudes Toward the United States, No. 2, September 11, 1953 (Office of Intelligence Research: Department of State), Box 5, Entry 2462, Paris Embassy 1936-55, Consulate Records, RG 84, NARA, p. 15. 102 Ibid. 103 Ibid., 20.
} 
Chinese communists. ${ }^{104}$ Even though most of the sample heard of germ warfare in Korea, only thirteen percent believed that reports were true. ${ }^{105}$ French communists led the effort to cast the United States role in Korea negatively. The communist newspaper L'Humanité frequently reported stories that the war was not going well for Americans. At the time of the State Department's survey there was little doubt that the rumors of germ warfare stemmed from communists. On the morning of the polling, the communist paper"s headline reported that "46,000 U.S. soldiers have deserted since start of Korean War," and that Stalin was right when he stated that "the Korean War was unpopular with American soldiers." ${ }^{106}$ French communists benefitted from an easy American target when General Matthew Ridgway arrived from the battlefields of Korea in May 1952 to take command of NATO forces.

When Matthew Ridgway assumed the position of Supreme Commander of Allied Forces Europe (SACEUR), the Korean War, the French Indo-China War, and the ideological battle of the Cold War all converged. Ridgway's position was not just a military one. Correspondence between J. Bonbright, the Assistant Secretary of State for European Affairs, with the endorsement of Secretary of State Dean Acheson, orientated Ridgway prior to taking over such an important post. This correspondence included a memorandum outlining the key considerations that Ridgway needed to understand before assuming his duties. The primary theme of the document was that everything Ridgway said and did in Western Europe carried great weight. ${ }^{107}$ As SACEUR, Ridgway

104Ibid., 15.

105Ibid.

106 Outgoing Telegram from American Embassy Paris to Secretary of State Washington, January 6, 1953, Box 5, Entry 2462, Paris Embassy 1936-55, Consulate Records, NARA.

107 Bonbright to Secretary of State, "Notes for Informal Discussion with General Ridgway," May 21, 1952, Foreign Relations of the United States, Vol. V, Part I, Western European Security, Document 162, at http://history.state.gov/historicaldocuments/frus1952-54v05p1/d162, accessed April 28, 2014. 
was "the personal embodiment of NATO itself." ${ }^{108}$ He had the "politico-military responsibilities" of building public support for NATO, improving European morale, stimulating national leaders to take actions desired by the US, and soothing European differences. ${ }^{109}$ Ridgway was essentially a "roving U.S. Ambassador" who needed to show constant diligence because "unfriendly elements" of Europe patiently waited for him to falter so they could unleash a "propaganda barrage" against the United States. ${ }^{110}$ Communists represented the most unfriendly segment of Europe that Ridgway needed to face. Ridgway was warned that "Commies" planned a huge protest demonstration to greet him." ${ }^{111}$ The warning from State Department leaders was not empty.

General Ridgway arrived in Paris to assume his command on May 27, 1952. The Paris that Ridgway entered was politically charged and looked more like a police state than an open democracy. Ridgway landed at Paris's Orly airport as a distinguished guest. Outgoing SACEUR General Eisenhower, top French government officials, and hundreds of newspaper reporters welcomed him. Ridgway's initial statement revealed the cooperative tone that he wished to set during his time as SACEUR. He was bringing to his post, the experience of leading "sixteen nations of differing languages, creeds, races, and colors" mixed in one United Nations' fighting force on the battlefields of Korea. ${ }^{112}$ Despite Ridgway's experience fighting in World War II and Korea, as SACEUR, he "entertained no aggressive designs against any country whatsoever in the world," but "would see to it that no aggression comes to destroy or merely endanger the

\footnotetext{
108 Ibid.

109 Ibid.

${ }^{110}$ Ibid.

${ }^{111}$ Ibid.

112 Benjamin Welles, "Ridgway in France to Lead Alliance," The New York Times, May 28, 1952 in Proquest Historical Newspapers.
} 
liberties dear" to NATO countries. ${ }^{113}$ Leadership of an international coalition to maintain peace was of paramount importance at this juncture in history. The backbone of NATO was a new European Defense Community. Coinciding with Ridgway's arrival was a meeting in Paris of European Defense Community leaders to sign the documents officially creating a "European army" that included German troops from the newly rearmed West Germany. ${ }^{114}$ The rearmament of Germans, along with Korea, stood as the biggest points of contention for the French.

French Communists planned a most unpleasant greeting for General Ridgway. An indicator of what Ridgway might face came in protest on the streets of Paris the days before his arrival. On May 23, communists mobilized at the urging of their newspapers to display their dejection of impending arrival of the "microbian general" who supposedly approved germ attacks on communist fighters in Korea. ${ }^{115}$ The left-wing protestors gathered at rush hour train stations chanting 'Assassin Ridgway,' 'Ridgway go home,' and 'we want peace."”116 Ridgway was not yet present to comply with the demands. Much of the early protest stemmed from European-wide communist demonstrations against talks to bind Western Europe closer together with a European army and the subsequent rearming of Germany. ${ }^{117}$ Communist leaders hoped to draw Parisian blue collar workers into the anti-America protest by painting anti-Ridgway graffiti on factory walls and timing events around the end of workdays and during

\footnotetext{
113 "General Ridgway in Paris," The London Times, May 27, 1952 in Proquest Historical Newspapers. 114 Benjamin Welles, "Ridgway in France to Lead Alliance," The New York Times, May 28, 1952 in Proquest Historical Newspapers.

115 Robert C. Dotty, "Paris Reds Launch Anti-Ridgway Riot," The New York Times, May 24, 1952 in ProQuest Historical Newspapers.

116 Ibid.

117Ibid.
} 
weekends. ${ }^{118}$ They also appealed to Parisian theater goers by putting on play called "Colonel Foster Pleads Guilty" that portrayed the Korean conflict from the communist point of view. ${ }^{119}$ The French police disrupted this event, ripping down the stage sets and tear bombing the audience. ${ }^{120}$ French communist newspaper, Ce Soir, printed an open letter to Ridgway's three-year old son asking why his father "destroyed people and houses and dropped microbe bombs?" ${ }^{121}$ In these waves of protest in Paris before Ridgway arrived, anything American became a target. An American reporter was beaten at St. Lazare train station and cars driven by Americans were stoned. ${ }^{122}$ The Parisian police arrested 186 communist demonstrators in these events and both sides suffered numerous injuries. ${ }^{123}$ No fatalities were reported in these manifestations, but both the communists and police learned the other's tactics and prepared for the main event, Ridgway's arrival.

The Ridgways arrived to a greeting by General Eisenhower. After about an hour of ceremony at the airport, Ridgway traveled ten miles through Paris en route to his hotel at Versailles. A Parisian spectator of the event likely recalled memories of military occupation in previous years. Prior to Ridgway's plane landing at Orly, thirty-three French bombers tore through the skies as a sign of force. ${ }^{124}$ Newspaper accounts estimated that anywhere between 4,000-20,000 French uniformed and undercover

\footnotetext{
118 A.E. Jeffcoat, "Parisian Reds Briefed on Germ Warfare as Welcome for Ridgway," The Wall Street Journal, May 21, 1952 in Proqest Historical Newspapers.

119 Ibid.

120 Ibid.

121 Ibid.

122122 Robert C. Dotty, "Paris Reds Launch Anti-Ridgway Riot," The New York Times, May 24, 1952 in ProQuest Historical Newspapers.

123 Ibid.

124 “General Ridgway in Paris," The Times, May 28, 1952 in Proquest Historical Newspapers.
} 
police guarded the route of the motorcade. ${ }^{125}$ "At every twenty-five yards of the ten-mile route armed French police stood on alert, motorcycle police swept the road clear into the city, and parked all along the route were vans filled with helmeted Guards.” ${ }^{226}$ This security came in response to the "weeks of anti-Ridgway fulminations in the communist press and threats of rioting and demonstrations." ${ }^{227}$ The American press satisfactorily reported that "there were virtually no signs of Communist activity" during Ridgway's first day in Paris. ${ }^{128}$ The most offensive thing the Ridgways saw on the way to their hotel were signs reading "Ridgway Go home" that "Communist hoodlums" plastered to buildings on the route. ${ }^{129}$ Lack of protest this first day gave American reporters the incentive to paint communists as cowards and feminine. The only French leftists brave enough to display anti-Americanism on the route of the processional were a few chanting women in suburbs. ${ }^{130}$ The male leaders of the party apparently "evaporated in the face of tough, rigidly controlled and ubiquitous police."131

Instead of taking on thousands of armed and ready police, the French Communist Party withheld its protest against Ridgway until the day after his arrival. On May 28, some 15,000-20,00o French communists moved to get the "war criminal" out of their capital. ${ }^{132}$ The bulk of the protestors were not the women of the day before, but

\footnotetext{
125 “4,000 Paris Police to Guard Ridgway,” The New York Times, May 27, 1952 in Proquest Historical Newspapers.

${ }^{126}$ Benjamin Welles, "Ridgway in France to Lead Alliance," The New York Times, May 28, 1952 in

Proquest Historical Newspapers.

127 Ibid.

128 Ibid.

129 “4,00o Paris Police to Guard Ridgway," The New York Times, May 27, 1952 in Proquest Historical Newspapers.

${ }^{130}$ Benjamin Welles, "Ridgway in France to Lead Alliance," The New York Times, May 28, 1952 in

Proquest Historical Newspapers.

${ }^{131}$ Ibid.

${ }_{132}$ Michel Pigenet, "History: Street Battle in Paris Against the U.S. General Ridgway," L'Humanitie, May 25, 2012, , from online archives of Bibliothèque nationale de France.
} 
young male factory workers. ${ }^{133}$ Both the police and the protestors approached the situation with the intention to fight. Skirmishes broke out all over Paris with some 370 injuries, many severe. ${ }^{134}$ Parisian police arrested 718 protestors and shot and killed two demonstrators. ${ }^{135}$ That night, Communist Party Secretary Jacques Duclos was arrested by police after they found on his procession a loaded firearm, concealed club, and two freshly killed pigeons. ${ }^{136}$ Duclos's dead pigeons captured the imagination Parisians and Americans alike. French police claimed that Duclos frantically smothered the pigeons before his arrest to "prevent them from being released and to lead trackers to their subversive lair." Duclos on the other hand suggested that they were "eating pigeons" given as a gift from a rural Frenchman. ${ }^{137}$ Police placed the fowl's corpses on ice so a veterinarian could preform an autopsy to determine if they were "pot or postal pigeons." 138

The anti-American and anti-Ridgway protests marked a turning point in FrancoAmerican Cold War relations. De Gaulle's government suppressed French communists, and ousted them from parliament in 1946; despite their critical role in the resistance movement. French communists resented French reliance on the United States most. Ridgway's appointment as SACEUR signified a necessary moment of action. American militarism and fear of being drawn into another world war weighed heavily on French communist leaders. ${ }^{139}$ The governments of both France and the United States were

\footnotetext{
133 Ibid.

134 Ibid.

135 Ibid.

${ }^{136}$ Robert Dotty, "Duclos, Reds' Chief, Arrested in Paris as Foe of U.S. Riot," The New York Times, May 29, 1952, in Proquest Historical Newspapers.

137 Ibid.

${ }^{138}$ Ibid. The autopsy revealed that they were merely domestic pigeons, possible to be used as peace doves. See Kuisel, Seducing the French: The Dilemma of Americanization (University of California Press, 1993), 49.

139 Kuisel, Seducing the French, 48.
} 
fighting against fellow Party members in Asia, and if another world war started, it would be between NATO countries and the Soviet Union. General Eisenhower was the military face of the United States in France as the first SACEUR, but not a good target for the communists. Eisenhower represented a liberator and friend to France who had not been actively involved on a combat front since World War II. General Ridgway, however, was a communist fighter coming from the battlefields of Korea. The popular image of Ridgway was a warrior with a grenade strapped to his chest, ready for battle. ${ }^{140}$ The assumption of a more militaristic commander of NATO in Paris coincided with Antoine Pinay's election as Prime Minister of France in March 1952. Pinay was the first true conservative leader of France since World War II. He had a reputation of collaborating with the Vichy during the war, and was in no way friendly to the left. Under Pinay's leadership, French communists faced even more isolation from politics. Pinay reinstated laws passed in the wake of the 1848 revolution that ousted King Louis Philippe. In 1952, it again became unlawful for crowds to gather without official government authorization. ${ }^{141}$ Ridgway's arrival was a chance for communists to test this restrictive law. They learned that Pinay was serious. His police force was prepared and treated the demonstration as a communist attempt to train a new generation of shock troops for fighting a civil war. ${ }^{142}$ In the wake of the Ridgway demonstrations, the French government closed down sixteen communist newspapers throughout France. ${ }^{143}$ They also raided communist headquarters in Paris and other French cities in hopes of finding

\footnotetext{
${ }^{140}$ A.E. Jeffcoat, "Parisian Reds Briefed on Germ Warfare as Welcome for Ridgway," The Wall Street Journal, May 21, 1952 in Proqest Historical Newspapers.

${ }^{141}$ Robert Dotty, "Duclos, Reds' Chief, Arrested in Paris as Foe of U.S. Riot,” The New York Times, May 29, 1952, in Proquest Historical Newspapers.

142 "Charge Against Duclos," The Times, May 30, 1952, in Proquest Historical Newspapers.

143 Robert Dotty, "Duclos, Reds' Chief, Arrested in Paris as Foe of U.S. Riot," The New York Times, May 29, 1952, in Proquest Historical Newspapers.
} 
evidence to arrest more of the red leaders. ${ }^{144}$ American Ambassador James Dunn was pleased with the "efficiency and firmness that the French government displayed in suppressing the disorders” and sent congratulations to Prime Minister Pinay. ${ }^{145}$ Pinay's response indicated that the swift action had little to do with the safety of Ridgway, but more broadly represented his desire to deal with insurrection and organized attempts to disrupt law and order. ${ }^{146}$ Upon taking office, Pinay and his confidants resolved to deal with "Commie insolence on [the] first appropriate occasion." ${ }^{147}$ The Ridgway protest revealed positive and negative foreign policy outcomes to the United States. A large segment of France was not happy with U.S. foreign policy in Asia, but a pro-American French government was in place. The repressiveness of that pro-American government ultimately broadened anti-American feelings in France, however. ${ }^{148}$

The shared Franco-American memory of World War I and World War II helped alleviate some of the tension surrounding Ridgway's arrival to Paris. When Ridgway assumed command of NATO forces in Paris, the United States hoped for a future in which its Western European allies maintained the strongest presence on the globe. Through the protest and attempts to restore Franco-American relations, the past remained stable ground to articulate international relations. French communists planned to mar Ridgway's arrival in controversy while Pinay's cabinet wished to welcome him with grand ceremony. ${ }^{149}$ Pinay's government wished to not only "honour

\footnotetext{
144 Ibid.

145 Ambassador Dunn to the Department of State, May 29, 1952, "Conference Files, lot 59 D 95, CF 108: Telegram, Foreign Relations of the United States, 1952-1954, Western Europe and Canada vol. VI, part 2, No. 520, at http://history.state.gov/historicaldocuments/frus1952-54vo6p2/d520, accessed April 23, 1014. 
the new supreme commander," and suppress protest. ${ }^{150}$ More important was the wish to "express the gratitude of France to the first American general officer to set foot on French soil in the landings of 1944." ${ }^{151}$ Ridgway's leadership in the distant battlefields of Korea stirred controversy, but he was a hero returning to France. Pinay felt that it was necessary to focus on this aspect of the man. Ridgway reciprocated respect to France through its own war memory. After the ceremony welcoming Ridgway to Paris, his heavily protected "convoy of cars" entered Paris travelling "along the Champs Elysees to the Arc de Triomphe, where General Ridgway "laid a wreath on the tomb of the unknown Soldier." ${ }^{52}$ Like so many other Americans before him, Ridgway began his new relationship with Paris by showing acknowledgement and understanding of their past sufferings.

Memory allowed the leaders in both countries to show the fundamentals of the amicable relationship they wanted. Ridgway's acclimation period, coupled with more communist activity in Paris, stifled chances of him leading American Memorial Day ceremonies in Paris, even though he arrived on the eve of the holiday. ABMC Secretary Thomas North arrived in Paris a few weeks before Ridgway to oversee the Commission's operations. North was present for the anti-Ridgway demonstrations, but none of them interfered with the ABMC's work. On the day of Ridgway's arrival North wrote to Chairman George Marshall and let him know that the ABMC's business had gone on as normal during the protest. He reported to his boss that he "had the usual accumulation

\footnotetext{
${ }^{150}$ Ibid.

${ }^{151}$ IBid.

152 “4,00o Paris Police to Guard Ridgway," The New York Times, May 27, 1952, in Proquest Historical Newspapers.
} 
of problems to solve, but nothing of unusual importance." ${ }^{153}$ At the time of the letter, North was planning a Memorial Day ceremony at Suresnes, and General Eisenhower had personally inspected the cemetery beforehand and given his approval. The respected general would not attend, however. North reported that the highest American dignitary that would attend the ceremonies at Suresnes was Ambassador Dunn. ${ }^{154}$ North wrote General Marshall the following month to inform him that the Memorial Day during the heightened anti-Americanism proved "inept." 155 The failure of the day resulted from the $\mathrm{ABMC}$ allowing American veterans organizations to handle most of the planning. North did not provide specifics of what went wrong during the ceremony, but concluded that private organizations lacked the "training to handle such affairs," and indicated that they did things that "gave notable offence to more than one key French official." ${ }^{156}$

Shortly after General Ridgway's arrival to France he sought to capitalize on the positive French memory of his D-Day connection and traveled to the Normandy beaches to speak at the eighth anniversary of the Allied landings. The New York Times reported that it was highly "suggestive that almost the first act of General Ridgway was to return to the beachhead where he led the assault on Hitler's Europe." ${ }^{157}$ For Ridgway, rural Normandy was a safer zone than urban Paris because of demographics and strong memories that Normans had of liberation. Ridgway was an honorary citizen of

\footnotetext{
153 North to George Marshall, May 27, 1952, Box 161, Folder 6, ABMC File, Papers of George C. Marshall, GCML.

154 Ibid.

155 North to George Marshall, June 23, 1952, Box 161, Folder 6, ABMC File, Papers of George C. Marshall, GCML.

${ }_{156}$ North to George Marshall, May 27, 1952, Box 161, Folder 6, ABMC File, Papers of George C. Marshall, GCML. The offensive conduct took place at St. James cemetery according to North, but the tone of his letter indicates that the ceremony at Suresnes followed the same pattern.

157 Anne O'Hare McCormick, “The Lesson of D-Day May Not be Lost on Stalin,” The New York Times, June 7, 1952, in Proquest Historical Newspapers.
} 
Normandy and on his anniversary visit greeted as "an acclaimed liberator." ${ }^{158}$ The Times wondered how the same man could be "denounced as a monster by the Communists in Paris" and days later be embraced as a hero? ${ }^{159}$ The conclusion of American reporters was, of course, that the "Normans speak with the true voice of France." ${ }^{160}$ With the physical reminder of American sacrifice around him, Ridgway let "the lords of communism" know that freedom, sacrifice, and the common good is what NATO countries believed in, and would die for again if need be. ${ }^{161}$ The Normandy beaches represented Hitler's ultimate failure of turning to militarism to achieve his objectives. Allied victory at D-Day was the start of the Nazis' demise. The American press saw Ridgway's selection of the D-Day beaches to give his first major speech appropriate because it might remind Stalin that he would face the same outcome as Hitler if he chose to rely on militarism to combat NATO. ${ }^{162}$

By the end of the summer, when some of the public scrutiny of Ridgway faded from the atmosphere in Paris, Ridgway had his chance to engage with the memory of the dead at Suresnes along with George C. Marshall and Prime Minister Pinay to formally tie his vision of the future with the sacrifices of the past. The ABMC's WWII extension on the Suresnes chapel neared completion as communist protest engulfed Paris. The Commission eagerly awaited Congressional appropriations for a dedication ceremony that would improve on that year's failed Memorial Day ceremony. Marshall wrote the Chairman of the House Appropriations Committee, Clarence Cannon in the early summer of 1952 to let him know that ABMC work moved along rapidly, outpacing

\footnotetext{
158 Ibid.

159 Ibid.

160 Ibid.

161 Ibid.

162 Ibid.
} 
Congressional funding. Marshall desired Suresnes to be dedicated "as soon after completion as possible," because it was important to have graves of American war dead open to the visiting public. ${ }^{163}$

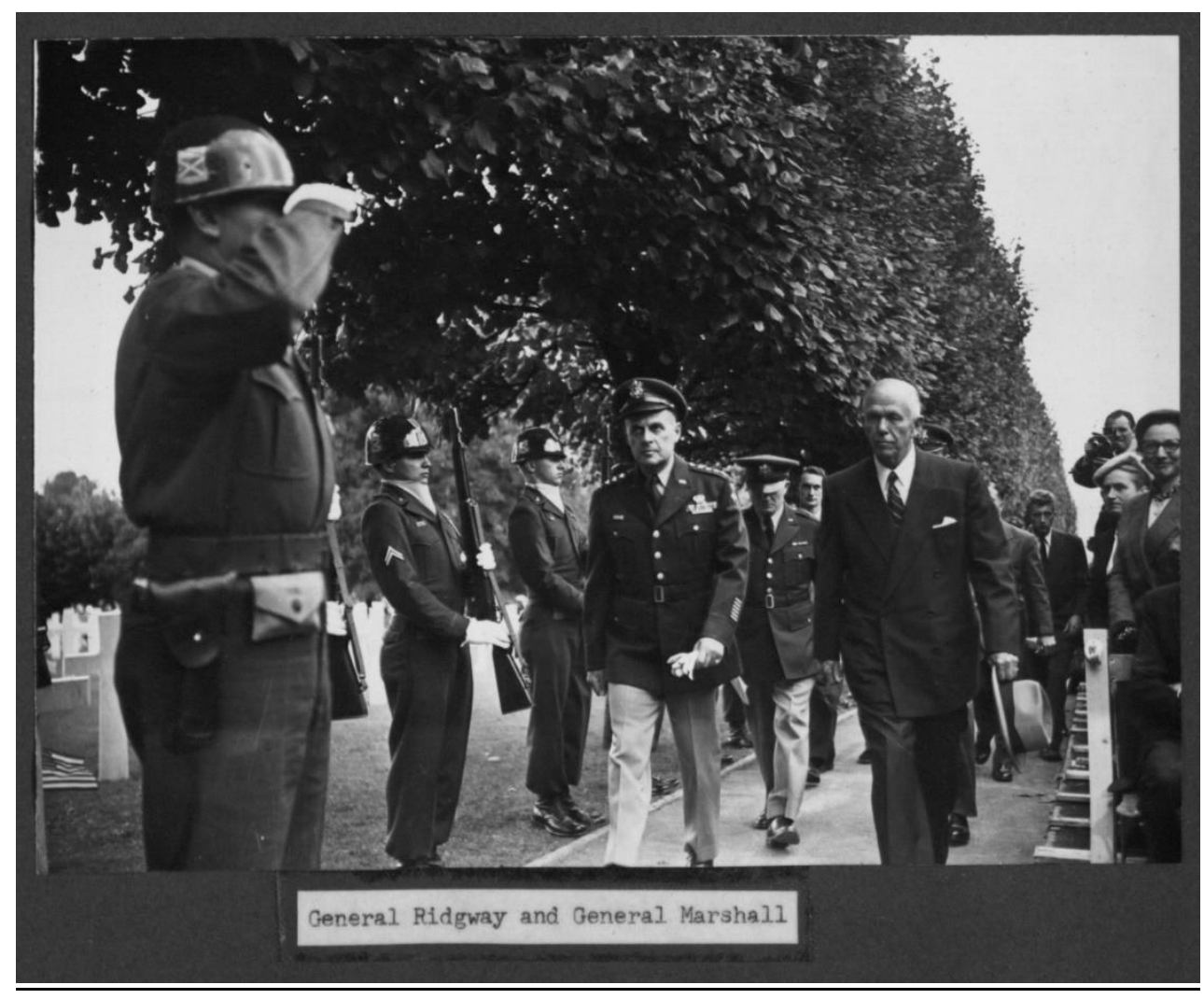

Photo 5.4: U.S. Marshall and Ridgway arrive for Suresnes dedication ceremony, September 14, 1952. Source: ABMC Archives, Arlington, VA.

Marshall maintained a keen interest in using American memory of the World Wars to bolster Franco-American relations. In 1950, President Truman fired Secretary of Defense Louis Johnson after the unpreparedness of the U.S. military to engage in large scale military endeavors became evident. Truman replaced him with George C. Marshall. Marshall primarily worked to restore morale of the United States armed forces and rebuild them from the demobilization that followed World War II. While

${ }_{163}$ Marshall to Representative Clarence Cannon, June 20, 1952, Box 161, Folder 6, ABMC File, Papers of George C. Marshall, GCML. 
Marshall attempted to restore the U.S. military to its former prominence, he remained chair of the ABMC. This unique position placed Marshall in the situation to elevate the mission of the ABMC. During this time, Marshall used his position as Secretary of Defense to defend the ABMC from potentially crippling alterations. As part of the rebuilding process, the Defense Department saw fit to cut the ABMC's officer allotment in half from ten to five, feeling that the five officer billets might have better use elsewhere. ${ }^{164}$ This proposed cut came at the height of the ABMC's World War II commemorative work. Secretary Thomas North stated that, during the Korean War, budget cuts forced them to "several construction" projects while "veterans and relatives of the dead" recurrently worried that the job would never be completed because interest in WWII was passing away." 165

Marshall took action upon hearing of the possible cuts, fearing that they might retard the ABMC's progress and result in poorly maintained cemeteries. He personally wrote General Omar Bradley, Chairman of the Joint Chiefs of Staff to laconically remind his former pupil that in addition to his many other duties, he "still seemed to be Chairman of the American Battle Monuments Commission.”166 Marshall warned Bradley that the cuts to ABMC personnel might create conditions of poor maintenance in cemeteries and upset the ever-increasing number of visitors travelling to the hallowed locations. ${ }^{167}$ Marshall sent out a second letter days later to the Defense Department's Management Committee Chairmen, General Joseph McNarney reporting that if the

\footnotetext{
164 Thomas North, Memorandum for Members of the Commission, no. 147, March 13, 1951, Box 161, Folder 3, ABMC File, George C. Marshall Papers, GCML.

165 Thomas North, One Soldier's Job, II-21.

166 George C. Marshall to General Bradley, March 13, 1951, Box 161, Folder 3, ABMC File, George C. Marshall Papers, GCML. 167 Ibid.
} 
personnel reductions impeded on ABMC's mission the "over-all morale factor" of American civilians and soldiers could plummet. ${ }^{168}$ This was entirely undesirable to Marshall while he labored to prepare a fighting force for Korea. If it looked like the government had abandoned the venerated WWII remains, soldiers might hesitate to offer their services in future wars. In this instance, the power of Marshall's name and position saved the ABMC. Instead of falling from ten to five officer billets, the ABMC actually increased its officer assignments to twenty-two. ${ }^{169}$

The following year Marshall stepped down from his position as Secretary of Defense and began his civilian life. Marshall wrote President Truman during this first year of retirement and filled him in on the ABMC's entire WWII commemorative plan. President Truman personally responded to Marshall, letting him know that he hoped "we can do what you suggest" because "I think it is a good idea." ${ }^{170}$ At the end of Truman's letter, he handwrote a promise to Marshall that "I'll do everything I can." 171 The full support of President Truman, along with Chairman of the Joints Chief of Staff Omar Bradley, demonstrated the cultural weight of ABMC sites. Some of the Defense Department's support for ABMC requests waned after Marshall's leadership there ended, but a strong respect for the ABMC's mission lingered in the Pentagon. In 1953, new Secretary of Defense Charles Wilson wrote General Marshall to personally deny the ABMC's request that their officer assignments be extended for a longer periods than others because the nature of ABMC work required continuity. Secretary Wilson

\footnotetext{
168 George C. Marshall to Joseph T. McNarney, March 16, 1951, Box 161, Folder 3, ABMC File, George C. Marshall Papers, GCML.

169 Memorandum for General Marshall, March 21, 1951, Box 161, Folder 3, ABMC File, George C. Marshall Papers, GCML.

${ }_{170}$ Truman to Marshall, January 23, 1952, Box 161, Folder , ABMC File, George C. Marshall Papers, GCML. ${ }^{171}$ Ibid.
} 
regretfully told Marshall that tours in Korea took priority, and the ABMC could not receive special treatment. Nevertheless, Wilson assured Marshall that "the Department of Defense stands ready to cooperate with the ABMC in every possible way to facilitate" its important work. ${ }^{172}$ Marshall traveled abroad in the period to personally assess if appropriate commemoration of the World Wars was taking place abroad. He participated in ceremonies and witnessed how ABMC cemeteries cemented bonds between nations on this trip.

The impetus for Marshall's trip in September 1952 seems to have come from four reasons: a letter from a discontent mother regarding her son's grave in Normandy (introduced at the beginning of this chapter), Marshall's desire to officially assess the work of the commission he led, the need for an American speaker as prominent as Pershing to kick-off a new wave of dedications, and a popular figure on the ground to join Ridgway in a public plea for NATO and united European army. ${ }^{173}$ The ABMC wanted Marshall to take this trip and participate in the Suresnes dedication. Secretary North envisioned the dedication of Suresnes to rival the grand Montfaucon dedication of 1937. ${ }^{174}$ Aside from President Truman, North saw Marshall as the American speaker most capable of winning over the French. ${ }^{175}$ Marshall agreed to participate in the Suresnes rededication, which would hopefully remedy the poor Memorial Day service there in the wake of communist protests. He departed the United States in the late

\footnotetext{
${ }^{172}$ Secretary of Defense C.E. Wilson to George Marshall, February 27, 1953, Box 161, Folder 9, ABMC File, George C. Marshall Papers, GCML.Papers of George C. Marshall, ABMC File, Folder 9, Box 161. 173 George Marshall to Edith Eustis, "George Marshall's Memorandum for the Members of the ABMC," November 14, 1952, Box 161, Folder 8, ABMC File, George C. Marshall Papers, GCML. And "Memorandum for General Marshall: Suresnes Dedication," February 6, 1952,Box 161, Folder 4, ABMC File, George C. Marshall Papers, GCML.

174 North to Marshall, February 6, 1952, Box 161, Folder 4, ABMC File, George C. Marshall Papers, GCML. 175 North to Marshall, February 6, 1952, Box 161, Folder 4, ABMC File, George C. Marshall Papers, GCML.
} 
summer of 1952 with his wife Katherine. On Marshall's tour, he visited all of the ABMC's new WWII sites and reported all of his observations back to the ABMC's other commissioners. The entire trip reveals that just as ABMC sites acted as anti-war statements and commitments to democracy in the interwar years, they now refracted hues of the Cold War.

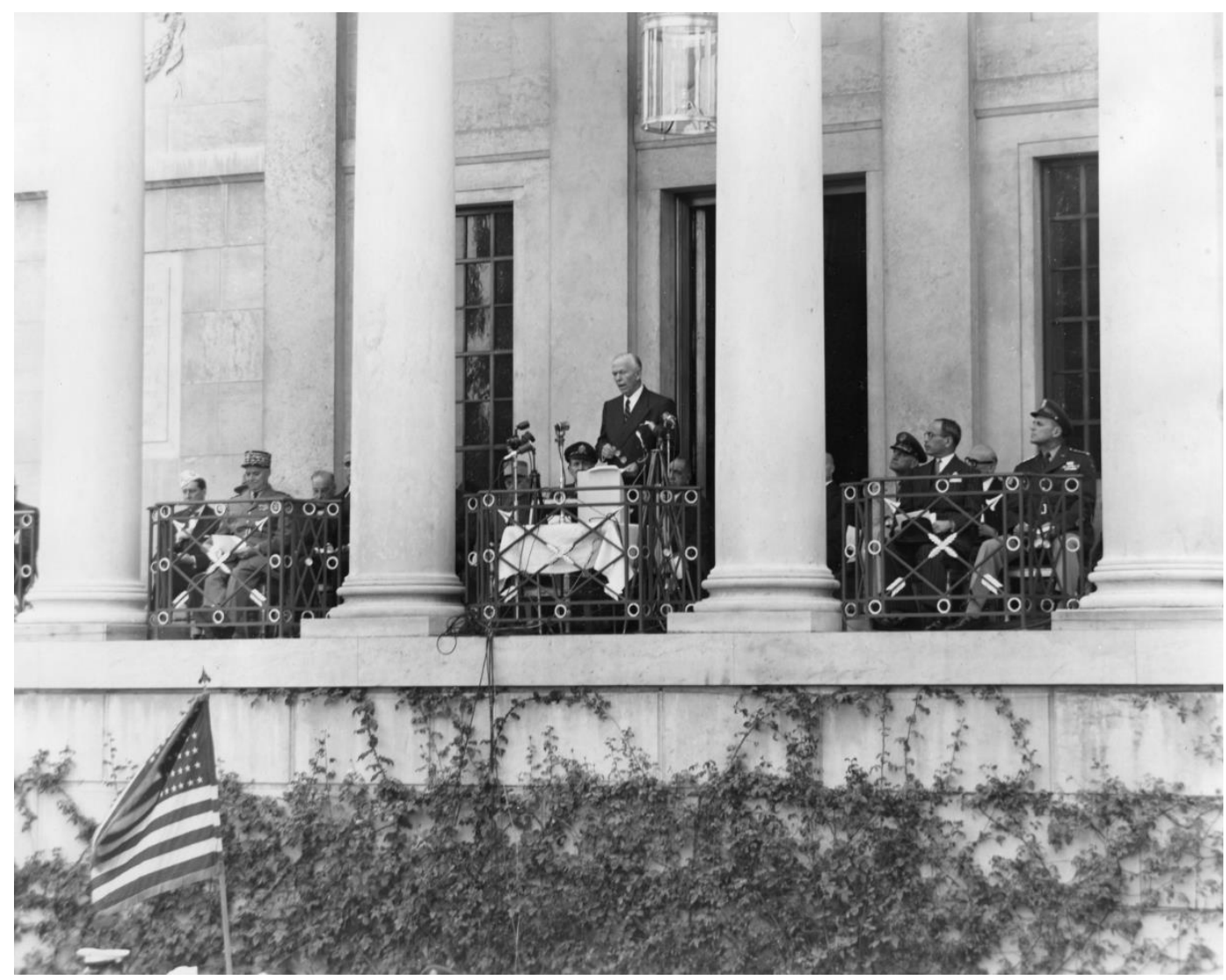

Photo 5.5: Marshall speaks during dedication ceremony. Source: ABMC Archives, Arlington, VA. 
The pinnacle of Marshall's inspection tour came at the rededication of the Suresnes American Military Cemetery outside of Paris. The dedicatory ceremony of the new American WWII cemetery at Suresnes effectively showed the clear uses of memory as an assertive weapon for the United States in ideological battles of the Cold War. In the summer of 1952, French disdain for the Korean War, French colonial struggles in Indochina, and French resentment of its dependence on the United States converged at the rededication ceremony of Suresnes American cemetery. At the dedication, Marshall served as the keynote speaker from the United States, along with General Matthew Ridgway, and America's ambassador to France James Dunn reading remarks from President Truman. French speakers included President Auriol, Marshall Juin, and Prime Minister Antoine Pinay. Much like the WWI dedications, the connection of the U.S. and France through commitment to democracy prevailed. More prevalent in the speeches, however, was Cold War policy, Asian Wars, and articulation of new foreign policy goals through the channel of memory. The text of the ceremony in many ways read as a response to the communist campaign against General Ridgway that rocked Paris only months earlier.

Marshall's speech sounded like a firm lecture to Europe based on his experience with the past. He began his lesson recalling the connection that WWI had to WWII and his participation in the first Memorial Day service in France at the Meuse-Argonne American Cemetery in 1919. ${ }^{176}$ Sadly, the "same conflict" of WWI was resumed on the same battlefields only two decades later, lamented Marshall. He recalled the repetition, explaining that one American division "occupied the exact sectors" in both wars. ${ }^{177} \mathrm{He}$

\footnotetext{
176 "Remarks of George Marshall at Suresnes Dedication," September 13, 1952, Box 171, Dedication Files, ABMC Records, RG 117, NARA. 177Ibid.
} 
then expanded the connection to the Korean conflict, relating that a soldier of that division served as a lieutenant during WWI, then a Corps Commander in WWII, and sacrificed his life leading the same division in "far off Korea." ${ }^{178}$ Using this soldier as an example of "terrible repetition," and sacrifice, bridged all of America's modern wars to the international audience. ${ }^{179}$ Marshall hoped that all American soldiers' sacrifices might lead to "genuine bonds of good will and good faith on this earth." 180 Yet, he sensed that a "spiritual unification of Europe" was a prerequisite for peace. Recent political events showed that this unification still obliged nourishment. ${ }^{181}$ He hoped that the "men who lie buried here in some other world beyond our conception may be aware of the efforts we are making to promote peace and understanding." ${ }^{182}$ He then turned to the recent Ridgway riots. Marshall never implicitly stated that communism acted as the barrier to European unification, but the audience likely made the connection when Marshall put forth his hope that American remains were "deaf to the propaganda" calling for America to go home and "leave Europe to the mercy of a ruthless aggression." ${ }^{183}$ It pleased Secretary North that Marshall tactfully addressed the scrawls of "Yankee go home," plastered all over Paris. ${ }^{184}$ Dead American service members spread all over France in ABMC cemeteries would never go home, nor would the living, until Europe no longer needed them. Marshall's example of the American soldier who fought in World War I, World War II, and died in Korea showed America's commitment

\footnotetext{
178 Ibid.

179 Ibid.

180 Ibid.

181 Ibid.

182 Ibid.

183 Ibid.

184 North, One Soldier, VII-1.
} 
to containing "ruthless aggression" wherever it arose. It tied the present wars to the French memory of liberation as well.

General Ridgway was the next American speaker at the rededication. Ridgway did not comment on the recent attacks that French communists made in his name. Instead of a soldier, he wore the hat of ambassador that the State Department informed him that he often would need to don. Much of Ridgway's speech imparted the ideology behind NATO and general combativeness towards communism. He acknowledged that the event celebrated was American, but that America should not be the centerpiece. The ideals presented by speakers at the Suresnes ceremony belonged to "all people of all lands to who life without freedom is worse than death." ${ }^{185}$ American remains at Suresnes rested not in France, but in the "soil of freedom."186 Ridgway saw France, and the rest of Western Europe, as "brothers" who possessed values that "separate men from beasts." ${ }^{187}$ These values were individualism, charity, truth, and faith in God. ${ }^{188}$ Ridgway, like Marshall, did not explicitly label communists as the beasts, but it is clear that they were the target. American remains in France served as reminders to all NATO countries of their shared cultural values. Ridgway hoped that the pilgrimage to American remains might reinvigorate the crowd to back policies that "resolved to deter aggression, or crush it to the earth if unable to prevent its occurrence." ${ }^{189}$ The memory of American dead hopefully compelled the living to work together. The American service members that

185 "Remarks of George Ridgway at Suresnes Dedication," September 13, 1952, Box 171, Dedication Files, ABMC Records, RG 117, NARA.

186 Ibid.

187 Ibid.

188 Ibid.

189 Ibid. 
remained in France were there to provide physical force whenever a challenge to the values arose. Living troops in Europe would "defend freedom continuously." 190

Ridgway also unknowingly provided the audience an explanation of how memory functioned as a diplomatic tool. He noted that "devout and earnest men and women" traveled to Suresnes every year since its creation and would continue to do so in the future. ${ }^{191}$ Perhaps reflecting on his difficultly finding the appropriate words to speak on such a solemn occasion, Ridgway concluded that there "is repetition in what has been said and what will yet be spoken at such ceremonies." Every year someone will stand before the American dead and speak of "pride, humility, renewed resolve, and rededication of the living" to accomplish what previous generations failed to, Ridgway told his audience. ${ }^{192}$ Repetition did mean that these sites had a shelf-life for usefulness. Interacting with the memory of American military dead was repetitious, but not commonplace. ${ }^{193}$ Some of the most important aspects of human life required repetition. Visiting military remains was akin to attending church service or reciting a well-known devotional. Communion with American military dead, like spiritual reflection, "renewed the moral strength and courage" of those willing to participate. ${ }^{194}$ Ridgway's conception of American military cemeteries made them sites that leaders and citizens should use frequently. These sites transcended the present and remained relevant. The dead linked the living to the past, perpetuated a memory, and provided direction for the future.

\footnotetext{
190 Ibid.

191 Ibid.

192 Ibid.

193 Ibid.

194 Ibid.
} 
French speakers similarly used American WWI and WWII sacrifice to evoke an image that current Cold War conflicts fit the same mold. They also confirmed that American memory indeed provided France an avenue to highlight their own national power. French President Auriol opened the ceremony with the assurance to the dead that regardless of recent anti-Americanism, France guards your graves with reverence, honors your memory, and pledges to watch over the Franco-American friendship. ${ }^{195}$ This type of declaration mirrored similar French promises in the past. It was different, however, because now American dead would feel the truthfulness of such promises by knowing that French and American soldiers currently "sacrificed in the Far East for the same ideals of justice and freedom" that they died for. ${ }^{196}$ Maintaining peace was the predominant Franco-American goal for memory throughout the interwar. Now, fighting together in the Cold War best commemorated the memory of the dead. Prime Minister Pinay, who had recently suppressed French communists, also employed the sacred space of Suresnes to tie American soldier dead to French soldiers fighting in Indochina. In an eerily prescient speech, Pinay thanked American dead fighting in the World Wars and thanked the living for "still fighting in Asia." 197 He noted that Frenchmen associated the dead American soldiers within the walls of Suresnes with "our valiant soldiers in Indochina" who currently sacrificed to "safeguard our civilization." 198 These remarks demonstrated that Pinay viewed the French Indochina War in the same light as the World Wars. They also showed Pinay capitalizing on the ingrained connection that

195 "Remarks of President Auriol at Suresnes Dedication," September 13, 1952, Box 171, Dedication Files, ABMC Records, RG 117, NARA.. 196 Ibid.

197 "Remarks of Antoine Pinay," September 13, 1952, Box 171, Dedication Files, ABMC Records, RG 117, NARA. 198 Ibid. 
Americans felt to the French in order to tie the Indochina war to the safety of both democratic nations. A French memory tying their current fighting in Vietnam with American memory in WWII also contributed to the French resistance narrative.

The United States was not yet involved in Indochina at the point. Marshall and Ridgway only had Korea as a comparable example of America sacrifice to use as commentary in the present. But, within two years of the Suresnes dedication France lost in Indochina and the United States moved towards one of its most controversial and costly wars in Vietnam. The rhetoric used by American leaders like Marshall and Ridgway tempered greatly as Asian conflicts became more controversial. Yet, Marshall comfortably reported to the $\mathrm{ABMC}$ commissioners that he found the work of the ABMC entirely "satisfactory" and that the dedication of Suresnes Cemetery was "exceptionally well organized and impressive" in $1952 .{ }^{199}$ In this early Cold War period, an assertive and militant memory of U.S. sacrifice was palatable in France.

Marshall continued to articulate his views regarding the utility of war dead abroad to the public through the 1950s. In a 1957, he followed a precedent established by General Pershing in 1934 and contributed an article to The National Geographic explaining the ABMC's work to the American public. Marshall's article was short, but effectively displayed his personal thoughts on what American military cemeteries represented. It was his opinion that "the establishment of American war cemeteries abroad was of great international importance" because "each stands as a perpetual reminder of the sacrifices the United States made in the common cause."200 This was

199 "George C. Marshall Memorandum to Commissioners," November 14, 1952, Box 161, Folder 8, ABMC File, George C. Marshall Papers, GCML.

200 George C. Marshall, "Our War Memorials Abroad: A Faith Kept," The National Geographic Magazine, Vol. CXI, No. 5, June 1957, p. 735. 
reflective of his push to have an American military cemetery present in the Philippines in the post-war period so Filipinos would have a positive memory of America on their soil. Marshall appealed to Americans to travel abroad and see ABMC sites. He had done so himself twice. Once, he visited graves as a young soldier in the American Expeditionary Forces. The second time was in 1952 when he "went as an old soldier seeking fallen comrades." ${ }^{201}$ The time that Marshall spent communing with American soldier dead abroad represented the "most poignant" experience of his life. ${ }^{202}$ He was proud to serve as the chairman of the government agency that kept faith with the dead, and proud of the fine work that the ABMC did. The ABMC, no matter how thorough it was, would never do enough for the soldier dead it commemorated. Marshall felt that the presence of Americans abroad was the "something more" that all ABMC cemeteries needed. The remains overseas belonged not just to bereaved families, but represented the "sons of every free man." 203

General Marshall wanted Americans to travel to Europe during the Cold War and show Europeans their positive characteristics. His ABMC had created convenient sites where the best of America could go on display. Anyone, world-wide who loved freedom, shared a kinship with American dead in Marshall's opinion. He urged all National Geographic readers to visit American remains and pay tribute to the dead as he had. ${ }^{204}$ Marshall's personal faith told him that there was "life as a spirit," and American military remains abroad held a constant vigil on the behalf of the United States. These dead "wanted visitation." 205 Marshall, like Pershing, anticipated cemeteries full of the living.

\footnotetext{
201 Ibid., 731.

202 Ibid.

203 Ibid.

204 Ibid., 733.

205 Ibid., 734.
} 
Marshall attempted to instill in Americans a sense of civic duty to visit American graves. Thousands of Americans traveled to Europe each year and once there, it required little effort or sacrifice to visit an American cemetery. The ABMC had taken steps to make all WWII sites easily accessible by railroad or highway. Marshall did not understand how any American enjoying a holiday abroad could not take the time to "ponder the deeper significance behind their blithe fun, and remember to who they owed the freedom of movement, and gaiety of Western European cities." ${ }^{206}$ America's military dead abroad represented the ideology that directly confronted the Soviet Union.

\section{$\underline{\text { Conclusion }}$}

The utilitarian function of the ABMC cemeteries remained clear throughout the very early stages of the Cold War, but became complicated once the United States became involved in large-scale military engagements in Asia. The complication relates to the shift of total war to limited war, an issue that will become relevant in the following chapter. ${ }^{207}$ American leadership desired the sacrifices of American soldiers in Asia to be equivalent to their World War counterparts, but this became difficult. U.S. military objectives in Asia did not achieve the totality of the World Wars. The military did not “mobilize all available national resources to defeat enemy regimes," nor intend to

206 Ibid., 735.

207 Bradley Coleman, "Recovering the Korean War Dead, 1950-1958: Graves Registration, Forensic Anthropology, and Wartime Memorialization," The Journal of Military History, Vol. 72 (January 2008), 183-184. 
"conquer, occupy, and reengineer opposing states." ${ }^{208}$ Instead, U.S. policy in Asia hinged on merely "containing" the enemy. In limited warfare, the handling of war dead changed, as did commemoration. Unlike casualties of the World Wars, American soldiers who died in Asia did not congregate in permanent overseas cemeteries. The deaths in these wars did not approach the numbers of the World Wars, bypassing the logistical need to stem repatriation, and the Asian countries did not seem like destinations American families willingly would travel to for visits to graves. In George Marshall's speech at Suresnes he proclaimed that the "dead cannot go home." ${ }^{209}$ This made their sacrifice and commitment to allies more important and lasting. In the remainder of U.S. battles in the twentieth century, every effort was made for the dead to go home. Thus, the American World War remains abroad became a precious commodity that would not increase. Their memory abroad continued to fluctuate with international situations and domestic political change.

208 Ibid., 183.

209 "Remarks of George Marshall at Suresnes Dedication," September 13, 1952, Box 171, Dedication Files, ABMC Records, RG 117, NARA. 


\section{Emissaries of Goodwill: Memory Diplomacy in the Post War Era}

"Perhaps we should make our removal from French soil complete by reinterring the bodies of these American men on American soil."1

The memory of American military remains in France moved away from that of aggressive cold warriors as the 1960 s progressed. The explicit ties that American leaders made between sacrifice in the World Wars and sacrifice in Asian wars essentially ended with large scale military intervention in Vietnam. As this war became unpopular, democratic American leaders primarily used memory of its past sacrifice in France as evidence for sustained friendship, not justification for making the Cold War hot. When French President Charles de Gaulle pulled France from NATO in 1966, American memory briefly became a weapon to attack the honor of France. This militant tone faded as social unrest built towards the transformative year of 1968. The widespread protest of the late 1960s, and discontent over Vietnam, made many Americans and Europeans question the usefulness of glorifying the military with the threat of nuclear annihilation looming large. The ABMC fought for its life in this period and attempted to prove its worth to Congress and the American people. With the conservative resurgence of Richard Nixon, the ABMC found a powerful ally and became more politicized than it ever had before. The ABMC's mission during the Nixon presidency became one of boosting public moral, bolstering American's pride in their past, and casting Vietnam in positive light.

\footnotetext{
${ }^{1}$ Quoting House Armed Services Committee Chairman Mendel Rivers from "Remove War Dead from French Soil Representative Urges," The New York Times, September 16, 1966, in ProQuest Historical Newspapers.
} 
President Kennedy visited Paris in the fall of 1961 on one of his first official overseas trips. His goal was to make a favorable impression on President de Gaulle and set a positive trajectory for Franco-American relations. Kennedy's presidency was one associated with youth, the future, and action. Still, Kennedy's visit to Paris proved that he understood the implications that historic memory played in the present. During a visit to the American Embassy the second day of his trip, Kennedy outlined to the staff the important uses of memory in diplomacy. He began his address to the embassy staff recounting a toast he delivered for de Gaulle the previous night that praised General's role in World War II and Franco-American friendship. "The United States' interest in France is not based on mere sentiment," he told the staff. ${ }^{2}$ It was "customary" and routine for officials on such visits to emptily "recall Lafayette and all the rest."3 Still, it was important for Kennedy that the embassy staff realize how memory served real national interests despite its obvious transparency. To prove his point, Kennedy provided a short history lesson to the staff. After George Washington's presidency "the sentimental memories of the Revolutionary War disappeared" between France and the United States. 4 The result of this amnesia was a quasi Franco-American naval war during the John Adams' administration. Kennedy noted that, out of all Adams' accomplishments, he wanted his epitaph to read "He kept peace with France." 5 What was the easiest way to keep peace in the Cold War era? Keeping the memories of past Franco-American amicability alive was one of the most efficient and useful ways,

\footnotetext{
${ }^{2}$ JFK to Embassy Staff, June 1, 1961, Box 233, JFK Papers, Kennedy Trip File, JFK Library, Boston, Massachusetts.

3 Ibid.

4 Ibid.

5 JFK's Toast at Elysees Palace, May 31, 1931, Box 233, JFK Papers, Kennedy Trip File, JFK Library, Boston, Massachusetts.
} 
Kennedy explained. "When you speak for the United States here, and when the French people comprehend the long movements of history, I believe you have a unique opportunity to be of service," Kennedy lectured. ${ }^{6}$ In other words, although engaging with memory sometimes seemed routine, it should not. It was the duty of Americans in France to frequently recall the past and remind the French of American sacrifices for them. Kennedy reminded the embassy that "France is larger than the total of its parts." 7 Its cultural influences spread throughout the globe. Friendship with France came with widespread benefits for the United States.

French culture and antecedents of its revolution existed all over the modern world. If the United States lost France as an ally, the reverberations would spread far past Europe. An assignment at the American embassy was "of the greatest possible importance to our common cause," and American staffers needed "to devote every energy to strengthening the common ties which bind us."8 Among the most common ties was memory. Kennedy's vision of memory as a diplomatic tool moved some of the responsibility for bolstering relations from the passive military remains buried in France. He placed more responsibility on the living to actively recall shared memories of mutual sacrifice in warfare. As a tangible part of that past, American dead still had a role to play. The memory of dead shifted back towards the Wilson's liberal uses. Their presence offered a means to secure Franco-American relations and provide assurance of mutual interest in the stability of the other. The instability of the 1960 s for the United States domestically and internationally made keeping a stable memory of dead abroad

\footnotetext{
${ }^{6}$ JFK to Embassy Staff, June 1, 1961, Box 233, JFK Papers, Kennedy Trip File, JFK Library, Boston, Massachusetts.

7 Ibid.

8 Ibid.
} 
difficult. The American escalation of Vietnam and shift from Democratic leadership to Republican leadership by the decade's end marked a return to a more politicized and responsive American memory abroad.

From the end of the Eisenhower administration through those of JFK, LBJ, and Nixon, misunderstandings between France and the United States often turned into nearly complete fissures. This chapter looks at the ways the American memory of the World Wars, represented through military remains in France, served as tools for leaders from both nations to continue positive engagement with one another despite high level disputes. It also analyzes the limitations of memory diplomacy in extremely tense periods of foreign relations. France's 1966 withdraw from the North Atlantic Treaty Organization threatened to close the gates of shared transatlantic memory, and challenged the usefulness of memory as a diplomatic tool. The chapter flows chronologically, focusing on the ambassadorships of James Gavin, Charles Bohlen, and Sargent Shriver. These three American diplomats represented the JFK, LBJ, and Nixon administrations. Their time in France coincided with the deepest Franco-American division of the $20^{\text {th }}$ Century, and the escalation of U.S. involvement with Vietnam. From the French perspective, President Charles de Gaulle retains a central role, because as president of the new Fifth Republic he held immense power. Considerable attention in this chapter is devoted to how all of these men engaged with the memory of the World Wars and American dead to articulate concerns in the present. President Nixon politicized the ABMC more than ever before. He used the favorable memories that the ABMC nurtured to address American discontent for Vietnam and to speak for the silent conservative majority in the United States. 
New Relations with the Fifth Republic

When John Kennedy assumed the American Presidency in early 1961, General Charles de Gaulle was two years into his second presidency of France. He entered this office promising to bring political stability and international creditability back to France. Ending the brutal war in Algeria and drawing up a constitution that created a powerful presidential office represented de Gaulle's initial goals. ${ }^{9}$ The Algerian situation produced a "grave hour for France" in which disheartened French commanders in Algeria threatened to invade Paris with paratroopers, overthrow de Gaulle, and continue the war to hold Algeria as a colony. ${ }^{10}$ Kennedy assured de Gaulle of his personal support, "as well as that of the American people," in this time of unrest because de Gaulle's attempts to "settle the tragic problem of Algeria" made him a "champion" for "liberty and the principles of democracy." 11 De Gaulle informed Kennedy that he "was deeply touched" by the sincerity "expressed to me in your name and in the name of the American people."12 This exchange indicated a shift in the way American policymakers viewed France. Following de Gaulle's return to power, no longer was France so "feminized" in official reports, but instead commonly received labels as a stronger, masculine, stable nation led by the 'towering, lionhearted, magnificently strong” General de Gaulle. ${ }^{13}$ This was not necessarily a welcome change. A stronger French ally

\footnotetext{
9 Costigliola, France and the United States, 121.

${ }^{10}$ Ibid., 131-32 and, JFK to de Gaulle, April 23, 1961, JKF Office File, Box 116, JFK Library, Boston.

${ }^{11}$ JFK to de Gaulle, April 23, 1961, Box 116, JKF Office File, JFK Library, Boston.

12 De Gaulle to JFK, April 24, 1961, Box 116, JKF Office File, JFK Library, Boston.

13 Costigliola, France and the United States, 121..
} 
seemingly benefitted the United States in its efforts to stifle Soviet expansion in Europe, but also challenged the dominant position that the U.S. desired to hold internationally. Prior to his first meeting with President de Gaulle in May 1961, President Kennedy received recommendations from respected diplomatic historian Arthur Schlesinger regarding how to interact with the French leader. Schlesinger warned Kennedy that de Gaulle was a "most impressive and commanding personality." 14 Schlesinger suggested that JFK not "be unduly intimidated" by de Gaulle's strong personality or commanding six-foot-six frame.15 De Gaulle inevitably would display "huffiness" during the meeting, but the young American president needed to respond with "candor" and "not hesitate to express disagreement."16 Winston Churchill frequently fought with de Gaulle and subsequently gained the General's deepest respect, while FDR attempted to passively charm him and utterly failed to personally connect. ${ }^{17}$ American efforts to stand up to de Gaulle diminished as his hostility towards U.S. foreign policy increased through the 1960s. The more consistent strategy that Washington officials adopted toward de Gaulle revolved around avoiding open confrontations and patiently waiting for nature, or an assassin's bullet, to remove the septuagenarian from office. ${ }^{18}$ In the meantime, Washington leaders dealt with de Gaulle through non aggressive channels, like positive memories of mutual sacrifice.

General de Gaulle was the last of the influential WWII allied leaders to govern over his nation. De Gaulle's person represented service in the Great War and leadership

\footnotetext{
${ }^{14}$ Arthur Schlesinger, Jr., “”Memorandum for the President: Mendes-France on De Gaulle,” May 23, 1961, Box 116A, France Security Folder, JFK Office Files, JFK Library, Boston.

15 Ibid.

16 Ibid.

17 Ibid.

18 Ambassador James Gavin to Secretary of State Dean Rusk, June 21, 1962, Box 21, Gavin Papers, Ambassador File, USAHEC, Carlisle.
} 
of the Free French movement. His connection with the Second World War brought him much respect from the Western powers. In Kennedy's opening letter to de Gaulle he acknowledged that "you [de Gaulle] have been a captain in this climactic struggle for two decades, and I am newly arrive upon the field."19 President Kennedy tasked esteemed American WWII veteran General James Gavin to head the American Embassy in Paris. Kennedy felt that Gavin's wartime association with de Gaulle gave him the experience needed in France during a "critical moment in history" when "powerful destructive forces" challenged universal Franco-American values. ${ }^{20}$ Kennedy hoped that Gavin, a famed general of the $82^{\text {nd }}$ Airborne division and liberator of Sainte-Mère-Église during the Normandy invasion, would "travel extensively outside" Paris while ambassador, to learn French culture and put forth a popular representation of American culture. ${ }^{21}$ It was obvious that Gavin's association with popular American WWII memory factored into his selection as ambassador. Gavin answered Kennedy's call to service with the stipulation that he serve no longer than two years. ${ }^{22}$ Months into his second year "worrisome business problems" and "schooling of his four daughters" compelled him to relinquish his ambassadorship and return to civilian life as a CEO in a profitable Boston consulting firm. ${ }^{23}$ Still, Gavin worked hard to establish positive relations with de Gaulle and France in his short tenure.

Gavin's correspondence with the White House and State Department showed an understanding that his association with World War II played a pivotal role as a Cold

\footnotetext{
19 JFK to de Gaulle, February 2, 1961, Box 116A, JFK Office File, JFK Library, Boston.

${ }^{20}$ Kennedy to Gavin, May 29, 1961, Box 21, Gavin Papers, Ambassador File, USAHEC, Carlisle.

${ }^{21}$ Ibid.

${ }^{22}$ Gavin to John Virden, July 31, 1962, Box 21, Gavin Papers, Ambassador File, USAHEC, Carlisle.

23 Ibid. and Gavin to Dean Rusk, July 31, 1962, Box 21, Gavin Papers, Ambassador File, USAHEC, Carlisle.
} 
War diplomat. Gavin explained to Kennedy's national security advisor, George McBundy, in May 1962 of his surprise over the reception he received because of his participation in the liberation of Normandy. ${ }^{24}$ It struck Gavin that "war is so meaningful to these people, and anyone who participated in the liberation of France is automatically well received at the outset." 25 He urged the Kennedy administration, and those thereafter, to "consider this [European WWII service] important criteria in selecting an Ambassador for the next ten to fifteen years." ${ }^{26}$ Gavin remained cognizant of his military experience throughout his tenure as ambassador. In the final months of 1961 he corresponded to a friend that he was "rather sensitive upon coming here [Paris] of having so much military background.” 27 This helped him deal with de Gaulle one-on one, but he worried that French intellectuals would ostracize him as a "philistine and militarist." 28 To avoid these labels, Gavin made extra effort to make the French view him as "more than just another General but a diplomat who has interest in the cultural life of France." Gavin achieved this by creating his own artwork, attending museum exhibitions, frequenting research institutions, and teaching French children nonmilitary applications missile technology. ${ }^{29}$

In addition to creating an aura of Renaissance man, Gavin fully understood the utility of his military background in French culture. Instead of facing ostracism because of his connections to the American military machine, many French doors opened to Gavin because of his WWII service. He reported to a friend that he was warned prior to

24 Gavin to George McBundy, May 11, 1962, Box 21, Gavin Papers, Ambassador File, USAHEC, Carlisle.

25 Ibid.

${ }^{26}$ Ibid.

${ }_{27}$ Gavin to Colonel Virden, December 14, 1961, Box 21, Gavin Papers, Ambassador File, USAHEC, Carlisle. 28 Ibid. 29 Ibid. 
going to Paris that "we [his family] should not expect to be invited often into French homes."30 Gavin had the opposite experience. He and his family frequently received dinner invitations. He attributed much of this to France's reverence for American sacrifice in World War II. Gavin was taken by the "depth and feeling" the French felt towards his role in the Normandy invasion. Wherever he went publicly, strangers approached him and spoke about it. ${ }^{31}$ Gavin's experience in France made him feel that his own culture took military sacrifices for granted. In France, respect for sacrifice and service were "not only widespread, but highly emotional.”32 Gavin's words showed slight envy that an American veteran in Paris received more respect than he did at home.

The previous chapters of this work showed American ambassadors frequently engaging with the memory of American military dead to comment on international situations. Less evidence exists to demonstrate that Gavin relied heavily on memory to bolster Franco-American relations. This is somewhat surprising considering his personal experience with French admiration of his WWII service. Gavin's short time as ambassador partially helps to explain why he adapted memories of the World Wars to contemporary issues less than his predecessors. Gavin is unique to twentieth century American ambassadors to France in that he was a veteran of the WWII European Theater. This surely gave him different perspective regarding memorial ceremonies. From his own accounts, it appears that Gavin often received honor and recognition from the French when he went out in public to honor the past.33 Similarly, as a

\footnotetext{
${ }^{30}$ Ibid.

${ }^{31}$ Ibid.

32 Ibid.

33 Ibid.
} 
commemorative speaker, Gavin was not an outsider looking in, but a participant of past events. The battlefields he visited and soldiers he paid respect to were often his own. Gavin did lead ceremonies for the $18^{\text {th }}$ anniversary of the D-Day landings by paying respect to the American dead at the ABMC's Normandy cemetery, but he also laid the cornerstone for an American museum at Sainte-Mère-Église, the Norman town he helped liberate. 34

Gavin was a vestige of World War II and used the memories of American sacrifice to achieve political ends. There is evidence that Gavin turned to the memory of American sacrifices in World War II for contemporary reasons. He related in a 1962 telegram to Secretary of State Rusk that at a luncheon with President de Gaulle he reminded that French leader that the United States was no longer an isolationist nation in the postwar world-the "thousands of our sons buried in Europe" attested to that. 35 This retort came in response to a "coldly harsh" recommendation from de Gaulle that the United States stay out of Western European affairs unless absolutely necessary. 36 Gavin's relation of the event to the State Department showed clear annoyance. His use of military remains to get a point across to de Gaulle showed the power he felt this tactic would have with a president who also participated in the war.

The sparseness of Gavin's utilization of American sacrifice to achieve political ends does not indicate that memory served a limited purpose during the Kennedy administration. Gavin was in himself a living incarnation of American WWII sacrifice for the French to engage with daily. Kennedy made his first visit to de Gaulle during the

\footnotetext{
34 "Gavin Visits D-Day Site to Honor Invasion Dead," June 7, 1962, The New York Times, in Proquest Historical Newspapers.

35 Telegram Gavin to Rusk, May 16 1962, Box 21, Gavin Papers, Ambassador File, USAHEC, Carlisle. ${ }^{36}$ Ibid.
} 
Memorial Day holiday of 1961 and returned home on the anniversary of D-Day. It is notable that he did not retrace the steps of Woodrow Wilson and visit Suresnes cemetery outside of Paris to deliver a prominent foreign policy address. In fact, Kennedy's trip itinerary included no visits to any of the American World War cemeteries. This is surprising considering the timing of Kennedy's trip and his record as a decorated World War II veteran of the Pacific Theater. Kennedy was, in a way, breaking protocol by not visiting these sacred locations. Yet, his words and actions throughout the trip still demonstrated a keen understanding that the memories of American sacrifice in the World Wars served contemporary ends.

After arriving in Paris on Memorial Day 1961, Kennedy told the audience gathered at Orly airfield why he traveled to France. He was humble, calling France "our oldest friend" and French "the language of free men." 37 Part of Kennedy's speech reflected why he might not engage so closely with sites of American memory. "I come not merely because of the past but because of future associations in defense of the west. . . France is the central figure of the common effort." $3^{8}$ Kennedy's youthful new administration aimed to reinvigorate a centuries old partnership. He desired to find solutions for ongoing problems and not dwell on won wars, unless necessary. Indicators of the past's usefulness came within the same speech. The future that the United States and France strove for was one where "France never again be a beach-head for war, but a fountain-head of peace," according to Kennedy.39 Even though JFK strove to set a tone

\footnotetext{
37 JFK’s Address at Orly Airfield, May 31, 1931, Box 233, JFK Papers, Kennedy Trip File, JFK Library, Boston.

${ }^{38}$ Ibid.

39 Ibid.
} 
of forward thinking for his trip, it was important to recall the somewhat recent memories of occupied France's liberation through American beachheads.

Despite the forward looking rhetoric of Kennedy's opening remarks in Paris, he did engage with the past. Hours after his arrival, his motorcade arrived at the Arc de Triomphe where both Kennedy and de Gaulle heard their national anthems and reviewed French troops. Kennedy then walked alone to the Tomb of the Unknown and lit the ceremonial flame as so many other Americans had for the past half-century. He then joined de Gaulle for minutes of prayer and silence before leaving. $4^{\circ}$ Kennedy dabbled in the past for the remainder of the evening. Four hours later, he delivered a toast that night during a formal dinner at the Elysee Palace that heavily relied on common Franco-American memories to improve relations between the nations. The lengthy toast dealt entirely with past associations between France and the U.S., recalling George Washington, Benjamin Franklin, John Adams, and the ideals of both nations shared commitment to the core ideals of their revolutions. Kennedy promised his audience that "the security of my country would be directly threatened if France were not independent, strong, and sovereign." 41 The United States wanted this for France above all else. He cited the memory of American dead as proof of this. "In this century, on two occasions, young men from my country have come to contribute to the maintenance of that independence and sovereignty." ${ }^{22}$ The American dead in France sacrificed not so America could hold power of France, but the two nations might be "one body." 43 It pleased Kennedy that the French leader he had the fortune to deal with was

\footnotetext{
40 Kennedy's Itinerary for May 31, 1961, Box 21, Gavin Papers, Ambassador File, USAHEC, Carlisle. ${ }^{41}$ JFK's Toast at Elysees Palace, May 31, 1931, Box 233, JFK Papers, Kennedy Trip File, JFK Library, Boston.

$4^{2}$ Ibid.

43 Ibid.
} 
de Gaulle, "the only great leader of World War II who occupies a position of high responsibility." 44 Kennedy tactfully ended his recounting of shared Franco-American experiences by asking the audience to drink to de Gaulle, a man who played an integral part in the Franco-American past.

Gavin, JFK's living embodiment of American World War II memory to France, stepped down in 1962. Kennedy quickly contacted President de Gaulle after accepting Gavin's resignation. He expressed to de Gaulle his reluctance to accept Gavin's departure because he achieved such satisfactory relations with France.45 Gavin's "unusually heavy family obligations" coupled with his lack of "private means," forced Kennedy to approve the resignation, however. He hoped that his personal letter, prior to any formal announcement, would provide clear answers to the inevitable rumors to follow. De Gaulle also learned from the letter that Kennedy wanted Charles Bohlen, one of America's most well-known and "distinguished professional diplomats" to take over the American embassy in Paris. Bohlen knew France well and possessed a keen admiration for the country.46 Outgoing Ambassador Gavin did not feel that Bohlen could fulfill Kennedy's expectations in Paris. 47 Gavin reasoned that Bohlen was "too identified with the thinking in the State Department and has led us into several impasses with both the Germans and the French." 48 Instead of possessing the military background that the French respected, Bohlen was a career diplomat that would likely be met with skepticism from the French. Kennedy did not follow Gavin's advice and placed Bohlen in America's important Paris embassy. Bohlen's ambassadorship

\footnotetext{
44 Ibid.

45 Kennedy to de Gaulle, July 26, 1962, Box 21, Gavin Papers, Ambassador File, USAHEC, Carlisle. ${ }^{46}$ Ibid.

47 Gavin to Kennedy, May 23, 1962, Box 21, Gavin Papers, Ambassador File, USAHEC, Carlisle. $4^{4}$ Ibid.
} 
coincided with the biggest Franco-American fracture in the twentieth-century. This required Bohlen to turn to popular memories of U.S. military dead in France to mend relations much more than his predecessor did.

\section{$\underline{\text { France Leaves NATO }}$}

In his memoir, Ambassador Bohlen reflected on de Gaulle's foreign policy views. "A great country has no friends, it only has interests," Bohlen reported de Gaulle saying.49 This was problematic for Bohlen. De Gaulle allowed no "place for sentiment in his government's analysis of international problems because he thought those who did were likely to be deluded or tricked." 50 Refusal to let sentiment influence foreign relations was seen by Bohlen as a barrier to Franco-American relations. "Sentiment" pervaded American foreign policy of "past, present and future," according to Bohlen. From a "cold blooded" realist perspective de Gaulle was correct, "sentiment should not play a role in policy." ${ }^{1}$ Nevertheless, the United States felt that its cultural ties with France and shared past merited friendship through sentimental ties. The true sign of friendship in foreign policy was a nation's willingness to "sacrifice for countries." ${ }^{2}$ Which Bohlen noted that the United States had done for France on multiple occasionsand France had once done for the United States. Bohlen's feeling that emotionalism

\footnotetext{
49 Charles E. Bohlen, Witness to History, 541.

$5^{\circ}$ Ibid.

${ }^{51}$ Ibid.

52 Ibid.
} 
belonged in foreign relations shined through during his ambassadorship in France. Bohlen, unlike his predecessor James Gavin, was not a participant in the European Theater of World War II. He was a career diplomat serving years as U.S. Ambassador to the Soviet Union and the Philippines. The inability of Bohlen's person to bring forth memories of French liberation seemingly made him a diplomat who more assiduously used the rhetoric of memory in his arsenal of diplomatic tools. His much lengthier ambassadorship to France, six years to Gavin's two, and the increasingly volatile Franco-American partnership likely contributed to his increased use of memory as well.

De Gaulle's belief that sentiment had no place in foreign policy did not stop Bohlen from pulling on the heart-strings of the French population when articulating the foreign policy objectives of the Kennedy administration. Bohlen's first Memorial Day address in Paris brought American remains in Paris from World War I and World War II into the nuclear age. He never explicitly named Korea or Vietnam, but noted that the dead of Suresnes "stretched round the world forming an unseen chain binding all ordeals we [the U.S.] have undergone and the victories we have won." 53 The conflicts represented in most U.S. conflicts saw "Americans fighting on the side of Frenchmen in a common cause in which we are still prepared to fight and if need be to die.” ${ }_{54}$ Bohlen was primarily concerned about what nuclear weapons might do to the legacy of American sacrifice for France, however. He told his audience that American soldiers from both World Wars entered into battle thinking that their wars "would be the last." 55 The world "now lived under a menace unimaginable even to them," Bohlen explained. ${ }^{6}$

\footnotetext{
53 Bohlen's Memorial Day Address at Suresnes, May 30, 1963, Box 3, Speech Files, Papers of Charles Bohlen, Library of Congress, Washington, DC.

54 Ibid.

55 Ibid.

${ }^{5}$ Ibid.
} 
The "nuclear bomb is indeed the ultimate weapon because it represents the apocalypse." 57 It was up to France and the United States to "promise the dead that the future shall not fail them" and to "arm ourselves against the dangers of war" instead of following past mistakes and arming "to build a war itself." 58 Bohlen lamented that "governments being what they are" caused disagreements and sporadically "ruffled historic harmony" between France and the United States. ${ }^{59}$ It was his hope that in an era of possible apocalypse, both nations stay together by embracing the "enduring bond of blood" each shared with one another. ${ }^{60}$ Instead of focusing on the divisive nuclear questions that plagued Franco-American relations in the early years of the Kennedy administration, Bohlen hoped that France and the United States might lead efforts to prevent nuclear war by reflecting on the memories of American dead. ${ }^{61}$ Bohlen felt that the living could only move past the "superficial" and overused rhetoric of FrancoAmerican friendship if they actively communed with the dead that forged the friendship. ${ }^{62}$ The presence of dead validated that the discourse was real and might continue.

Bohlen's next Memorial Day in Paris marked the twentieth anniversary of the DDay landings. Suresnes, not Omaha Beach was the platform in which Bohlen delivered his commemorative address. The desire to bridge World War I and World War II together as one representation of the Franco-American commitment to freedom and

\footnotetext{
57Ibid.

${ }^{8}$ Ibid.

59 Ibid.

60 Ibid.

${ }^{61}$ The U.S. and France clashed over American reluctance to provide France with nuclear weapons or the means to create its own nuclear weapons. This issue was one that plagued Gavin's time as ambassador. 62 Bohlen's Memorial Day Address at Suresnes, May 30, 1963, Box 3, Speech Files, Papers of Charles Bohlen, Library of Congress, Washington, DC.
} 
human justice factored into this decision. ${ }^{63}$ He wished not "to confine myself to this anniversary alone" because in both wars American lives were "rightly and truly sacrificed."64 Bohlen directed his 1964 remarks not on fear of nuclear weapons, but on the necessity of soldiers sacrificing their lives "before God and nature."65 Americans from both wars lying in "French soil added increased emotion" to Bohlen. ${ }^{66}$ The presence of American dead assured Bohlen that "our two countries are so deeply imbedded" in similar points of view that "no divergences of the moment can possibly mar or spoil the feelings of respect." ${ }^{7}$ The death of American soldiers was a sad occurrence. The presence of their remains abroad was a comforting thing in times of international strife, however. Military graves reminded arguing nations that each shared investment made for the other in blood. This reminder was particularly useful now that President Kennedy was dead and his predecessor was escalating the American conflict in Vietnam.

President de Gaulle increasingly took measures to parry American uses of its popular war memories against France. On this twentieth-anniversary of D-Day, Bohlen voiced a memory of American soldiers with no high-ranking French officials present to hear. In previous years, it was common for top French government officials to stand beside American officials to signal mutual respect. This was not the case in 1964 according to Bohlen's autobiography. It annoyed Bohlen that President de Gaulle allowed his personal pride to get in the way of such important commemorative events. De Gaulle and his Free French forces did not play a leading role in the Allies' D-Day

\footnotetext{
63 Ibid.

64 Ibid.

65 Ibid.

66 Ibid.

67 Ibid.
} 
invasion. Therefore, on the twentieth anniversary of the event, de Gaulle "would not let any French government official of any importance take part in the anniversary." 68 De Gaulle, thus made D-Day “un-history" in Bohlen's opinion. ${ }^{69}$ This mandate that no high-ranking French officials attend U.S. commemorative events stifled the usually open channels of commemorative exchange. The United States chose not to retaliate against de Gaulle by boycotting his important memorial ceremonies. Bohlen noted that France adopted an "opposite treatment" of ceremonies commemorating the anniversary of landings in Southern France at Toulon. De Gaulle and other government officials attended and made official statements at Toulon because "the Free French forces had participated.”70 Both Bohlen and his British counterpart stood with de Gaulle on this occasion to show their mutual interests in this historic episode. Bohlen added that thankfully a bomb planted in a flower pot on the stage failed to detonate and kill de Gaulle and the other dignitaries at this Toulon event. ${ }^{71}$

De Gaulle's reluctance in 1964 to participate in American ceremonies commemorating events which the French had no stake coincided with a general erosion of relations. American unwillingness to make France a nuclear power, and escalation in Vietnam factored prominently in this faltering partnership. From 1964 until 1968, the United States continually escalated its war with North Vietnamese communists. De Gaulle saw in Vietnam the pillars of America's flawed foreign policy-"naïve selfrighteousness, a readiness to quash smaller nations' independence, a tendency toward military actions that could engulf France in a world war, and wrongheaded persistence

\footnotetext{
${ }^{68}$ Bohlen, Witness to History, 546.

69 Ibid.

70 Ibid.

${ }^{71}$ Ibid.
} 
in containing 'Communist' expansion..." 72 As Vietnam intensified, so too did French resentment for U.S. foreign policy. Tensions came to a head in 1966 when de Gaulle withdrew from the North Atlantic Treaty Organization and called for the U.S. military to leave his country. French foreign policy experts articulated that the decision came about not because of anti-Americanism, but to combat a "mono-polar world dominated by the United States."73 De Gaulle hoped that France's action might empower other European nations to stand up to a United States that "all over the world used its power as it saw fit without consultation" of its allies. 74 Memorial ceremonies served as a battleground during this deterioration instead of the celebratory stage that they once were.

De Gaulle’s March 1966 announcement that France was leaving NATO and the U.S. military needed to leave France shocked the world. He gave the United States one year to remove all of its military personnel and bases from French soil.75 When de Gaulle delivered his demand to Secretary of State Rusk, it brought forth a visceral reaction from the head American diplomat. Rusk reportedly asked de Gaulle if his mandate included the "dead American soldiers in the cemeteries as well?" This angrily delivered question left de Gaulle in silence and gave Rusk at least some satisfaction in one of the darkest hours of Franco-American relations. ${ }^{76}$ Rusk's retort demonstrated the place that American remains held in diplomatic relations. The rhetoric of American military bodies in France throughout the twentieth century was one of friendliness and

\footnotetext{
72 Costigliola, France and the United States, 140.

73 Henry Tanner, "De Gaulle: Anti-American, or only Pro-French?,"The New York Times, February 27, 1966, in Proquest Historical Newspapers. mentioned often regarding France's withdrawal from NATO, but no good citations for the source are provided.
} 
supposedly meant perpetual respect. A French challenge to the established system required a powerful response. Rusk's instinctual turn to bodies showed the cultural significance Americans placed on their war dead. In the minds of most Americans, France owed its existence to American sacrifice. American death in both World Wars was the ultimate gift to France, but so was leaving American bones in French soil. This was one of the most powerful signals of trust that one nation could give to another. If de Gaulle led France to default on its NATO commitments, was his nation worthy enough to hold America's esteemed military dead? Both Americans and French addressed this question.

After Rusk's angry retort to de Gaulle about removing U.S. military remains from France, U.S. leaders worked to smooth out Franco-American relations. In a circular sent out to all European NATO missions and U.S. Ambassadors, Rusk urged anyone dealing with France to make it "very clear that there is an empty chair always ready and waiting should she [France] decided to return." 77 The American memory of sacrifice in the World Wars still offered a means to guilt France back into the orbit of the United States. Ambassador Bohlen believed that France expected the United States to "drag its feet, raise objections at every move, and in general behave in a bitchy fashion" throughout its military withdrawal. 78 The United States instead worked to accommodate French desires. President Johnson tried to do all that he could to meet de Gaulle's demands and Bohlen warned of the futility in "punishing or getting tough with France."79 Despite

\footnotetext{
77 Rusk to NATO Missions, March 28, 1966, Box 2185, SN 1964-66, Politics, Department of State, RG 59, NARA.

${ }^{78}$ Bohlen, Witness to History, 536.

79 Ibid.
} 
this acknowledgement of de Gaulle's steadfast commitment to U.S. withdrawal, Bohlen continued to attack the policy through the memory of American dead.

Bohlen understood that nothing could change de Gaulle's mind about NATO. Still, his Memorial Day address at Suresnes only two months after de Gaulle's announcement showed a visibly different tone. He did not fail to mention U.S. struggles in Vietnam as he had the previous two years. In this speech, Bohlen equated American sacrifices in both World Wars to the escalating war in Vietnam. It was not enough to pay respect to American bodies on the hillside overlooking Paris. He directed the audience to "not flinch from thinking of the new graves now being dug in Vietnam." 80 Fighting in Vietnam was not shameful. "People say that Americans are victims of their own idealism ... see things in black or white... and miss the real nature of the problems that confront us," Bohlen explained. ${ }^{81}$ He acknowledged if this was a fault, it was "a fault that harbors its own special virtue." 82 He reminded his French and American audience that America's commitment to idealism was the "mainspring" of its intervention all over the world the past twenty years. "Reflect on what the world would be like today" if the idealism that inspired the remains of Suresnes was absent in Americans, Bohlen demanded of his audience. ${ }^{83}$ The United States responded to "the appeals of the helpless, weak, and oppressed.” Sometimes it did so awkwardly, too late, or too faintly," but when the response came it was from "the most powerful nation on earth." 84 France was twice saved in recent memory by the idealism that the remains in

\footnotetext{
80 Bohlen's Suresnes Memorial Day Address, May 30, 1966, Box 4, Speech Files, Papers of Charles Bohlen, Library of Congress.

${ }^{81}$ Ibid.

82 Ibid.

83 Ibid.

84 Ibid.
} 
Suresnes represented. Bohlen did not want these bodies removed because France needed the reminder of American sacrifice in this hostile period. The dead at Suresnes showed that the United States "continued today as we have acted in the past" and they deserved to be saluted "without guilt or trepidation," the same as the living American soldiers ordered to vacate the ungrateful country. 85 Bohlen's message was succinct and seemingly intended to instill guilt into the French leaders for their recent actions.

The memory of American remains held a prominent place in public discussions in the immediate aftermath of de Gaulle's NATO decision. Following shortly after de Gaulle's March 1966 NATO decree, the French Defense Ministry announced the discontinuation of an annual ceremony honoring American Sargent Laurence Kelly at the Invalides Hospital in Paris. Sargent Kelly was an American soldier from Altoona, Pennsylvania shot accidentally by the French Homeguard on August 25, 1944 while rushing into Paris to be the first American liberator of the city. Kelly's shooters took the mortally wounded GI to a French pharmacist who organized an annual ceremony in his memory thereafter. Parisians and the American Legion's Paris Post No. 1 celebrated June 10 each year as Sergeant Kelly day. ${ }^{86}$ The French government allowed this celebration of Kelly's sacrifice to take place at the Invalides-perhaps the most powerful military shrine in France. The event was not a grand spectacle-it attracted approximately 150 participants each year. ${ }^{87}$ Cancellation of the event so quickly after the order for the American military to vacate France aroused calls of anti-Americanism and attacks against de Gaulle.

\footnotetext{
85 Ibid.

86 "France Forbids Shrine Rites for Yank War Dead," Chicago Tribune, April 14, 1966, in Proquest Historical Newspapers.

87 David Halberstam, "1,500 in France Honor Dead GI in Rite with Protest Overtones," The New York Times, June 11, 1966, in Proquest Historical Newspapers.
} 
The Defense Ministry held to its mandate that the ceremony not take place at the Invalides despite public discontent. Speakers for the Defense Ministry did publicly clarify that "the order was not directed at our American friends and allies and it would be unjust to interpret it that way." 88 The cancellation merely reflected a new policy of not allowing any private ceremonies at the Invalides. ${ }^{89}$ The French pharmacist who once cared for Kelly and organized the event moved forward with commemorative plans, despite her government's actions. She simply moved the event to Suresnes American Cemetery. Reporter David Halberstam attended the event at Suresnes and noted that a "feeling of protest" hovered over the entire ceremony.90 Attendance of the memorial increased ten-fold from the previous year. Instead of a paltry 150 mourners, 1,500 attended.91 Among these, most were French of the older generation wishing to prove that de Gaulle did not speak for the entire country and that his recent attitude towards American sacrifice in WWII "approached bad manners."92 Ambassador Bohlen attended along with French dignitaries such as ex-president Reynaud, anti-Gaullist politicians, and French generals. 93 The high point of the ceremony for the audience came when de Gaulle's representative, Jean Jurgensen, declared that "without the United States, France would no longer exist.”94 This brought forth spontaneous applause from the French attendees.

\footnotetext{
88 "France Acknowledges Debt to U.S. in Ceremonies for GI Liberator," The Washington Post, June 11, 1966, in Proquest Historical Newspapers.

89 David Halberstam, "1,500 in France Honor Dead GI in Rite with Protest Overtones," The New York Times, June 11, 1966, in Proquest Historical Newspapers.

90 Ibid.

${ }^{91}$ Ibid.

92 Ibid.

93 Ibid.

94 Ibid.
} 
This type of French reaction to de Gaulle dominated Bohlen's memory of the period. In his autobiography it stood out to him that many French desired to "show they were still pro-American, despite de Gaulle's break with the United States" because "they felt that his actions were a slur on French good manners." 95 Bohlen saw many French going out of their way "to demonstrate their good will to the representative of a country which had twice fought beside them on the battlefield of Europe."96

Engaging with the sentimental memories of American dead reversed no French policy. The U.S. military planned an incredibly efficient evacuation and some " 800,000 tons of war material and all airbases" were out of France a month before de Gaulle's deadline. 97 It was Bohlen's solemn duty to say goodbye to American military families who worshipped at the American Cathedral in Paris before their departure in March 1967. He lamented that "it is going to seem very strange not to have an American military presence in France ... this is the end of a long story which started on June 6, 1944."98 Only the remains from that day and other battles stayed in France as military reminders. The saddest aspect of the exodus to Bohlen was that a "natural affinity exists between French and Americans" that is made even greater where military families live. 99 He wanted the American families leaving to know that, as Ambassador, he knew that "Franco-American friendship is not merely a customary phrase, it is a real and enduring sentiment."100 Many Americans left France feeling that it was not the average Frenchman that wanted them gone, but the desire of an overly prideful de Gaulle.

\footnotetext{
95 Bohlen, Witness to History, 548.

${ }_{96}^{6}$ Ibid.

97 Ibid., 536.

${ }_{98}$ Bohlen's address to the Men's Club Dinner at the American Cathedral, March 7, 1967, Box 4, Speech Files, Papers of Charles Bohlen, Library of Congress.

99 Ibid.

100 Ibid.
} 
Bohlen's rosy view of Franco-American relations was not all true. Real French resentment towards American policies existed in the capital. Beginning in 1966 French protestors assembled at the U.S. embassy and countless petitions flooded the embassy's mailboxes. ${ }^{101}$ In early March 1966 over twenty-four young French protestors rushed past French guards at the U.S. Embassy screaming "U.S.A. Assassins" while hurtling ink bottles against the building. ${ }^{102}$ When Vice President Hubert Humphrey visited Paris in 1967 he was met at nearly every stop by protestors throwing eggs, paint, and rocks. ${ }^{103} \mathrm{~A}$ reader of the Los Angeles Times felt compelled to submit an open letter to the newspaper after seeing photos of French protestors burning American flags in public. He felt that the French "should be ashamed of themselves" and suggested they "visit some of the American cemeteries in France, where thousands of our boys are buried" to get a reminder that "they are free" because of our boys. ${ }^{104}$ The writer planned his own protest by cancelling his visit to France and compelling other Americans to do the same. ${ }^{105}$

Bohlen might have seen genuine French admiration for Americans through commemorative events, but negative stories persisted in the headlines. Enough so that Rusk's off-handed comment to de Gaulle about the removal of American dead in French soil actually received consideration in the halls of the U.S. capital. Chairman of House Armed Services Committee, Mendel Rivers (D-SC), drafted legislation in 1966 for the United States to "complete its military withdrawal from France by bringing home the

\footnotetext{
${ }^{101}$ Costigliola, France and the United States, 143.

102 "US. Paris Embassy Defaced as Youths Throw Ink Bottles," The New York Times, March 3, 1966, in Proquest Historical Newspapers.

103 Costigliola, France and the United States, 143.

104 Louis Lettini, "Displeased with France," The Los Angeles Times, April 13, 1967, in Proquest Historical Newspapers. 105 Ibid.
} 
bodies of the 60,501 American soldiers now buried" there. ${ }^{106}$ American corpses in France "gave their lives to save France from disgraceful defeat" and Rivers felt that if the current French attitude continued, the American bodies needed reinterred in American soil. ${ }^{107}$ Rivers proposed legislation never took flight. The bodies remained in the now hostile French soil. Bohlen left his Paris post in the winter of 1968. He departed feeling that so long as de Gaulle was in power "there would be very little chance of improvement in Franco-American relations," yet he remained an idealist. ${ }^{108}$ In his heart he knew that a "profound friendship between the United States and France remains in being," he had seen this in countless commemorative ceremonies. ${ }^{109}$ If an event emerged that tested the life of either nation, he knew that France and the United States would stand together as in the past. ${ }^{110}$ Replacing Bohlen was the younger, more optimistic, and charismatic Sargent Shriver.

Thawing Tensions: A Return to Positive Memories

Sargent Shriver began his ambassadorship to France in May 1968 during a time when relations between the two countries were "in a state of definite decomposition." 11 Worker strikes, student demonstrations, and anti-Vietnam protest engulfed Paris and

\footnotetext{
106 "Remove War Dead from French Soil Representative Urges," September 16, 1966, The New York Times, in Proquest Historical Newspapers.

107 Ibid.

108 Bohlen, Witness to History, 549.

109 Ibid.

110 Ibid.

111 "How Franco-American Relations Improved," unknown author, undated, Box 89, Speech Files, Sargent Shriver Papers, JKF Library, Boston. This document appears to be a draft of a State Department study written shortly after Shriver's ambassadorship.
} 
other French cities. The diplomatic situation started to improve slightly in 1968, nonetheless. President Johnson's decision in March 1968 to halt bombing over North Vietnam, coupled with his announcement to not seek reelection and allow Vietnam peace talks to begin in Paris, improved French perceptions of the United States. ${ }^{112}$ Sargent Shriver arrived in Paris at the start of a slight anti-American thaw. Still, the atmosphere in Paris was revolutionary. In May 1968, student riots and nationwide workers strikes joined forces and raged through the capital city. ${ }^{113}$ The revolutionary winds in Paris hinted to the start of a new era. French youth coming to age in the universities rose up against the old order, much like their counterparts throughout the world did in 1968. De Gaulle served as a particularly good example of the antiquated system. Instead of putting money into improving French domestic life and growing the economy, he spent most of his presidency in the pursuit of nuclear weaponry and a revitalized national image. ${ }^{114}$ These goals came at the expense of state funding for the universities. In May of 1968, French students nationwide mobilized to protest against de Gaulle and the outmoded university system. ${ }^{115}$ Student protests in Paris turned the streets into a battleground and eventually French workers joined demonstrations by staging the largest strike in Paris since the Paris Commune.

In this atmosphere, Shriver reported that he had two approaches to his ambassadorship. He could "let events take their natural course," or "try to make his Embassy and himself a part of those events." ${ }^{116}$ Shriver chose to assert himself into the

112 Ibid.

113 Ibid.

114 Castigliola, France and the United States, 155.

115 Daniel Singer, Prelude to Revolution: France in May 1968 (Chicago, Illinois: Haymarket Books, 1970), 54 .

116 "How Franco-American Relations Improved," unknown author, undated, Box 89, Speech Files, Sargent Shriver Papers, JKF Library, Boston. 
current events because he felt that they naturally aided in his objective to reestablish communication and restore confidence between France and the United States. ${ }^{117}$ A clear example of the Shriver's resolve to stop the deterioration of relations came from one of his wife, Eunice's, first actions upon arrival to their residence in Paris. Upon seeing her new home, Eunice inquired as to why the flagpole bore no American flag. Security told Mrs. Shriver that all of the demonstrations in Paris made it necessary to remove the Stars and Stripes because it attracted protestors. She flatly rejected this notion and ordered that the flag fly proudly over the family home. ${ }^{118}$

Shriver served in the South Pacific as a naval officer during WWII and received a Purple Heart. While he brought WWII service back to the Paris Embassy, he did not have the European theater service that Gavin did. Shriver's connection to the popular and well-liked Kennedy family elevated his position in French society. Newspapers reported French elation over Shriver's selection. ${ }^{119}$ A "new look" was coming to Paris, and the "Kennedy tie" of Shriver allowed him to immediately improve the U.S. image abroad. ${ }^{120}$ Shriver viewed his mission in Paris in the same light as his deceased brotherin-law, JFK. Kennedy's address to the Paris Embassy staff in 1961 impelled them to "to devote every energy to strengthening the common ties which bind us." ${ }^{121}$ This primarily meant spreading Americanism by setting a good example, but also by regularly engaging with popular anecdotes of Franco-American memories. Shriver brought Kennedy's call

\footnotetext{
117 Ibid.

118 William Manchester, "Our men in Paris: The Trying, engrossing daily task of the American ambassador and his 1,400 man payroll” (U.S. Embassy Publication, undated), Box 94, Sargent Shriver Papers, JFK Library, Boston, 12. 119 Joseph Goulden, "Shriver Named Ambassador to France," The Washington Inquirer, Box 94, Sargent Shriver Papers, JFK Library, Boston.

120 C.L. Sulzberger, "Foreign Affairs: A New Look in Paris," March 13, 1968, Box 94, Sargent Shriver Papers, JFK Library, Boston.

${ }^{121}$ JFK to Embassy Staff, June 1, 1961, Box 233, Trip File, JFK Papers, JFK Library, Boston.
} 
for devotion and energy to his ambassadorship. He wanted to "use himself to show something about the U.S. to as many French as possible" by staying out of "contentious areas" and looking "for areas where France and the United States could cooperate."122 Shriver's engagement with popular memories of American sacrifice in the World Wars was a lucrative channel to build a foundation for better relations. A publication about Shriver's administration stated that "if more Americans were aware of the investments each country had in the other's past, diplomacy might achieve more."123 It was Shriver's job to "not jar history loose on its hinges, but to keep the hinges oiled."124

Keeping the hinges of history oiled required Shriver to show strategy in his public comments. Prior to his arrival in Paris, State Department officials advised Shriver on what he should and should not say in any public statement. One thing he absolutely needed to avoid referencing "directly or indirectly was Vietnam." 125 He was instead supposed to craft a "story line" that flowed from the "proposition that from the time of our revolution until now, U.S. European relations have been generally characterized by an increase in U.S. power" relative to Europe's “amazing recoveries” from World War I and World War II. ${ }^{126}$ Shriver's speeches commemorating American military dead adhered to this advice.

Bohlen chose to explicitly link Vietnam to American sacrifice in the World Wars in the final part of his ambassadorship when the United States felt most defensive of its

\footnotetext{
${ }^{122}$ How Franco-American Relations Improved," unknown author, undated, Box 89, Speech Files, Sargent Shriver Papers, JKF Library, Boston.

${ }_{123}$ William Manchester, "Our men in Paris: The Trying, engrossing daily task of the American ambassador and his 1,400 man payroll” (U.S. Embassy Publication, undated), Box 94, Sargent Shriver Papers, JFK Library, Boston, 16.

124 Ibid.

125 Woodruff Wallner to Sargent Shriver, May 3, 1968, Box 78, Sargent Shriver Papers, JFK Library, Boston.

${ }^{126}$ Recommendations for Speeches, undated, Box 88, Speech Files, Sargent Shriver Papers, JFK Library, Boston.
} 
place in Europe. Vietnam had no place in Shriver's text when framing the American memory of past wars, however. In his first Memorial Day as Ambassador at Suresnes he relegated his focus mainly to American sacrifice in the Great War-likely because 1968 marked the fiftieth anniversary of that war's end. This speech reflected on the resolve of Franco-American relations and their ability to rise above cynicism to make a better world. ${ }^{127}$ Shriver continued to capitalize on this anniversary publicly and articulated the lessons that American World War I remains taught contemporary society. At St. Mihiel, Shriver delivered his homage to American remains in the French language. It delighted the French that Shriver tried such a feat despite his "terrible accent." ${ }^{28}$ Part of his address was broadcasted on French national television, and it elated Shriver that he had the chance to speak to so many Frenchmen through the medium of memory. ${ }^{129}$ Speaking in French was indicative of how Shriver wished to use Great War memories to improve relations. World War I represented a war in which the French proudly fought until the end, not one in which Americans swooped in as liberators.

On the golden anniversary of the war, Shriver wanted to not just remember American remains, but the "hundreds of thousands of young French graves that defended their homeland."130 Both French and American dead taught that death in battle did not favor one nationality over the other, that rampant nationalism brings death and destruction, and the future belongs to cooperative, not suspicious, minds. ${ }^{131}$

\footnotetext{
${ }_{127}$ Shriver's Suresnes Memorial Day Address, May 30, 1968, Box 89, Speech Files, Sargent Shriver Papers, JFK Library, Boston. This speech is in very poor condition and transcription of it was difficult. ${ }^{128}$ William Manchester, "Our men in Paris: The Trying, engrossing daily task of the American ambassador and his 1,400 man payroll” (U.S. Embassy Publication, undated), Box 94, Sargent Shriver Papers, JFK Library, Boston, 11.

129 Shriver to French Diplomatic Corps, October 2, 1968, Box 89, Speech Files, Sargent Shriver Papers, JFK Library, Boston.

${ }^{130}$ Shriver's Montsec Speech, September 22, 1968, Box 88, Speech Files, Sargent Shriver Papers, JFK Library, Boston.Translated by author. ${ }^{131}$ Ibid.
} 
Shriver hoped that the living did not tarnish the memory of World War I dead by highlighting their mistaken belief that they died "fighting the war to end all wars." ${ }^{132}$ It was the living, not the dead's, fault that war continued. In this age, France and the United States needed to look back to the Great War and find inspiration for "fraternal peace."133 Shriver addressed French diplomats weeks later and explained to him the personal revelations he gained from his St. Mihiel visit. It inspired him as ambassador to remember how France and the United States "so often worked together," as they should. ${ }^{134}$ He assured the French diplomats that the lessons he took from St. Mihiel represented not "isolated gestures," but something he would continue to perpetuate as ambassador. ${ }^{135}$

It seems overall that the fiftieth anniversary of the Great War's end came at an opportune time for the new ambassador. The chance to travel France and address the nation through positive memories of the Great War allowed Shriver to cast a favorable impression of himself and his nation quickly. Fiftieth anniversary ceremonies also provided a bridge for Shriver and de Gaulle to start a positive relationship. President de Gaulle held a large parade in Paris to commemorate Armistice Day. Colonel William Jones, an engineer for the ABMC sat in the reviewing stand near Ambassador Shriver during the event. His observations of the day revealed that the parade was a positive episode in Franco-American relations. "All of the Allies in World War I, except Russia," marched past the reviewing stand in the order they entered the conflict. ${ }^{136}$ The not so

\footnotetext{
132 Ibid.

133 Ibid.

134 Shriver to French Diplomatic Corps, October 2, 1968, Box 89, Speech Files, Sargent Shriver Papers, JFK Library, Boston.

135 Ibid.

${ }_{136}$ William Jones, "Service with the American Battle Monuments Commission, April 1, 1967 to June 30, 1974,” undated, Box 1, William Jones Papers, ABMC Folder, USAHEC, Carlisle, 17.
} 
long-ago expelled U.S. troops passed de Gaulle last and "the applause of the French crowd was greater than for any other [country] except the French." ${ }^{137}$ A similar sign of improving relations came at the end of the event when all ambassadors present approached de Gaulle to congratulate him on the event's success. Many noted that de Gaulle "talked longer with and was more cordial to Ambassador Shriver than any other." 138 This ceremony of memory positively opened the lines of communication in the strained Franco-American partnership and offered hope of better days.

The twenty-fifth anniversary of the Normandy landings came the following year. This occasion gave Shriver another chance to approach the French through popular American memory. Shriver visited Utah Beach to commemorate this event. His speech repeated the story-line of long standing Franco-American cooperation. He linked the real wall of "fire, concrete, and barbed wire" that Americans faced twenty-five years ago to a metaphorical wall of "mistrust, ignorance, misery, and oppression" that France and Americans faced presently. ${ }^{139}$ The only way either country could break these walls was through cooperation. Franco-American solidarity would salute the graves of dead Americans and show them that their offspring still had the ability to scale obstacles together. ${ }^{140}$

More striking than Shriver's words on this important anniversary was the overall atmosphere of the event he wished to create. Instead of a sad occasion, there was a light heartedness to much of the official anniversary. Much of Shriver's correspondence following the event centered on the $8^{\text {th }}$ Infantry Division's preparation of an "American

\footnotetext{
137 Ibid.

138 Ibid.

${ }^{139}$ Shriver's D-Day 25 ${ }^{\text {th }}$ Anniversary Address, June 6, 1969, Box 89, Speech Files, Sargent Shriver Papers, JFK Library, Boston.. 140 Ibid.
} 
picnic lunch" served to dignitaries on Omaha beach. ${ }^{141}$ He thanked a British General for joining him and his wife on our "little American picnic." 142 To Cornelius Ryan, writer of the book turned Academy Award winning movie The Longest Day, Shriver joked that "the world will be pleased to know that following your own private 'landing' on Omaha Beach, that you were able to get your motorized vehicle off the beach and back into battle without any casualties." 143 He also hoped that he enjoyed the "picnic" and thanked Ryan for attending and bringing more attention to the event. ${ }^{144}$ Officials in the American Battle Monuments Commission showed displeasure towards Shriver's attitude toward the important twenty-fifth anniversary. An ABMC engineer in Paris reported that Shriver actually wanted to hold the picnic inside of the Normandy cemetery, among the graves. ${ }^{145}$ The ABMC's Paris office immediately denied this request and Shriver appealed to ABMC executives in Washington, who upheld the denial. ${ }^{146}$ One ABMC representative met with Cornelius Ryan during the anniversary week and discussed the Shriver picnic with the Longest Day author. When reflecting on Shriver's request to hold the picnic inside of the cemetery, Ryan commented that "you're [the ABMC] lucky he didn't want to play touch football there."147

The ABMC found Shriver's people-to-people approach to diplomacy too informal for its mission. ${ }^{148}$ Shriver's participation in commemorative ceremonies received good

\footnotetext{
${ }^{141}$ Shriver to Commanding General EUCOM, June 30, 1969, Box 88, Speech Files, Sargent Shriver Papers, JFK Library, Boston.

${ }^{142}$ Shriver to Brigadier General Ian Christie, June 30, 1969, Box 88, Speech Files, Sargent Shriver Papers, JFK Library, Boston.

${ }^{143}$ Shriver to Cornelius Ryan, June 30, 1969, June 30, 1969, Box 88, Speech Files, Sargent Shriver Papers, JFK Library, Boston.

144 Ibid.

145 William Jones, "Service with the American Battle Monuments Commission, April 1, 1967 to June 30, 1974,” undated, Box 1, William Jones Papers, ABMC Folder, USAHEC, Carlisle, 18.

146 Ibid.

147 Ibid. Jones is quoting a personal conversation he had with Cornelius Ryan.

${ }^{148}$ Shriver's people-to-people approach grew from his appointment as first head of the Peace Corps.
} 
press and seemingly improved Franco-American relations, but sometimes made the ABMC cringe. For example, at the well publicized St. Mihiel commemoration in 1968, Shriver's small children reportedly ran around in a frenzy swinging on the protective ropes around monuments and "ducking in and out of them with no one trying to control them." 149 While this type of display possibly made Shriver seem more relatable to the average citizen, it was not the type of engagement with the memory of American dead that the ABMC was accustomed to. There was fear within the ABMC that Shriver's "disregard for diplomatic protocol" at their events might cause "ill feelings" instead of contributing to better Franco-American relations. ${ }^{150}$ This fear seemed somewhat misplaced, however. It was an "open secret" in France that President de Gaulle planned to make the twenty-fifth anniversary of D-Day the first one in which he participated. ${ }^{151}$ This never happened because he resigned two months before the event. It is unknown if Shriver would have curtailed the American picnic if de Gaulle attended.

149 William Jones, "Service with the American Battle Monuments Commission, April 1, 1967 to June 30, 1974,” undated, Box 1, William Jones Papers, ABMC Folder, USAHEC, Carlisle, 18.

150 Ibid.

${ }^{151}$ Ibid., 17. 


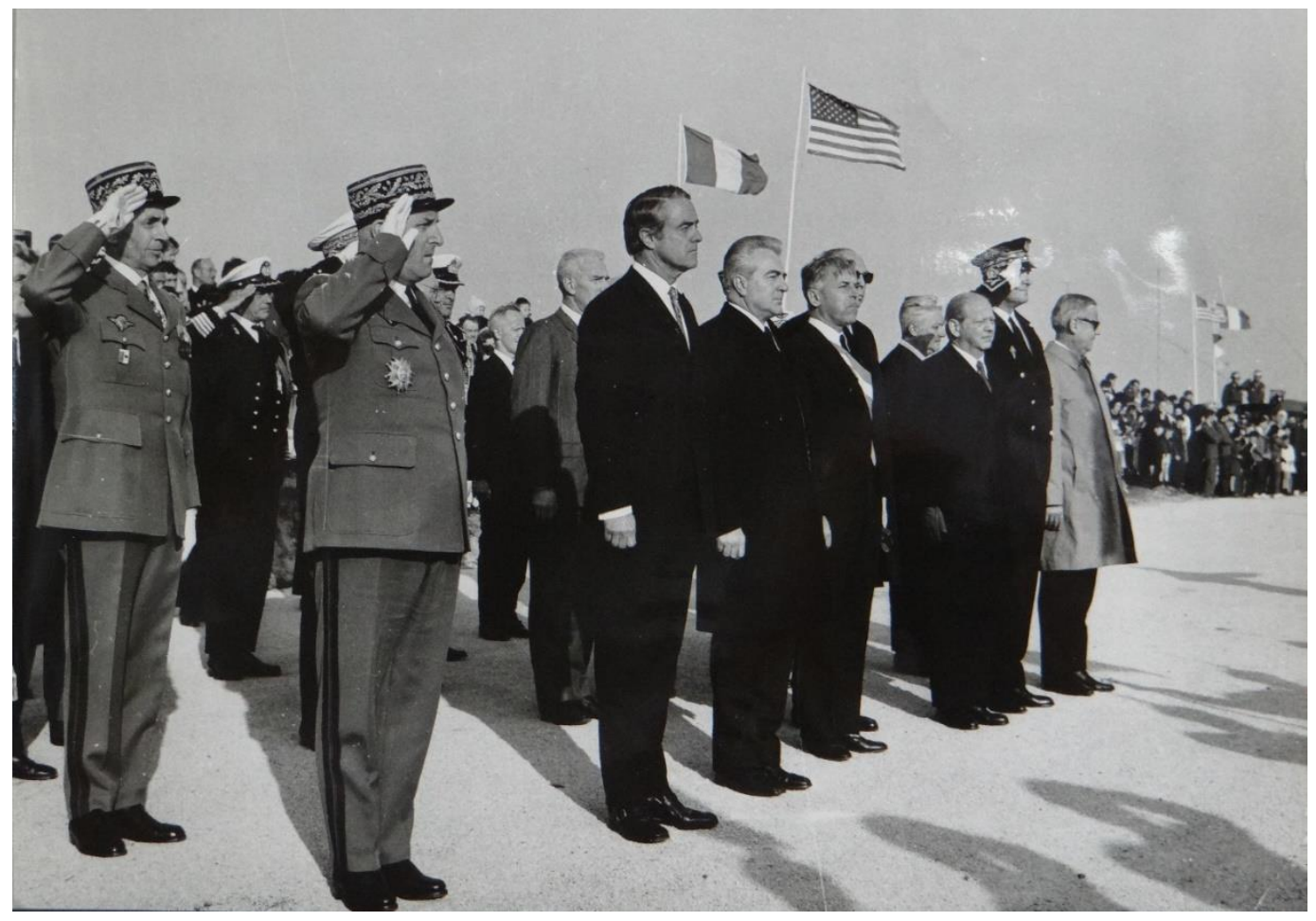

Photo 6.1: Ambassador Shriver at the twenty-fifth anniversary of D-Day, June 6, 1969. Source: Sargent Shriver Papers, JFK Library, Boston, MA.

Shriver's less formal approach to the anniversary of D-Day was reflective of a shift in D-Day memory where shared sacrifice and tragedy were accompanied by commercialization. A New York Times reporter attending the $25^{\text {th }}$ Anniversary at Normandy skeptically captured the new tone of the once solemn event. He noted that while the remnants of the landings and military cemeteries made World War II seem closer to the present at Normandy than anywhere else in Europe, a distance detached the invasion more from the present each year. ${ }^{152}$ Normandy was now "manicured and touristy" with "cafes, souvenir shops, and hotels." Young publicity men lingered in the crowd like vultures promising “to do this or that for someone's book, movie, or

${ }_{152}$ Drew Middleton, “25 Years Later in Normandy, D-Day is for Generals and Memory," The New York Times, June 7, 1969, in Proquest Historical Newspapers. 
television series" depicting the invasion.153 It was hard to believe that "anything great was done here," reported the author. ${ }^{154}$ It was not just the commodification of Normandy that stood out to the reporter, but also the public lack of understanding of the event. On multiple occasions, he witnessed aging veterans attempting to tell their account of the day to tourists only to realize by the end of their story that "the tourist was no longer listening." 155 After the event, the reporter reached the conclusion that the only redeemable thing about Normandy now was the dead, their memories, and individual experiences of mourners. The orators, bands, and generals all showed reflections of the bigger commodification. ${ }^{156}$ Shriver's post-ceremony correspondence showed that the reflections of the Times reporter had merit.

Sargent Shriver, Eunice, and returned to the United States in 1970, to allow President Nixon to appoint his own ambassador, and for Sargent to enter politics. The Shrivers' presence in Paris renewed some of the French perceptions of the United States. Throughout Shriver's two years at the American Embassy many things contributed to improved relations: LBJ's halting of bombing over North Korea and his decision to not seek reelection, Nixon's election and 1969 trip to Paris, the Apollo 11 moon landing, and de Gaulle's retirement.157 Shriver's embassy was a part of these events and he made a genuine attempt to improve the image of the United States. This often included visiting American graves to remind France of its shared past. Looking at Shriver's engagement with memory as a diplomatic tool indicates that he saw something lacking in this

\footnotetext{
153 Ibid.

154 Ibid.

155 Ibid.

156 Ibid.

157 "How Franco-American Relations Improved," Box 89, Speech Files, Sargent Shriver Papers, JFK Library, Boston.
} 
method by the end of his ambassadorship. His engagement with American dead leading up to the $25^{\text {th }}$ anniversary of D-Day called for progressive action from the public, not passive talk. At the $25^{\text {th }}$ anniversary at the American D-Day beaches, he was part of new spectacle of American memory. The American Battle Monuments Commission struggled to keep itself relevant in American culture throughout the 1960s. As Shriver called for action to commemorate the dead, the ABMC fought to maintain its prestige and attempted to remain relevant in U.S. culture. The final section will look at the decline of the $\mathrm{ABMC}$ and its attempts at public resurgence.

\section{The ABMC on the Offensive}

The American Battle Monuments Commission faced new challenges at the start of the 1960s. Visitation to ABMC cemeteries depended greatly on international circumstances, the location of the cemetery, and the war it commemorated. Cemeteries at well-known sites, like Normandy, garnered more visitation than others in more remote areas of France. By the early 1960s, the lagging visitation to ABMC sites and budget cuts made the relatively young government agency fear for its life. The New York Times reported in November 1961 that Americans no longer traveled to ABMC sites in the numbers that they used to. Relatives, in particular, did not visit the graves as they once did. At Suresnes American Cemetery, the most visited of the ABMC sites through the interwar years, only eighteen American relatives visited as of November 
1961. ${ }^{158}$ Tourists still visited the cemeteries according to the article, but "most visitors to these graves were French." 159 The concluded reason for the dwindling number of family visits was that the "graves are far from home and trips to Europe are expensive." 160 The drop in numbers was upsetting, but ABMC Secretary Thomas North was still pleased that the cemeteries brought in a large foreign audience. "What is perhaps not well appreciated at home is the great psychological impact upon foreign peoples of these solemn shrines," North reflected prior to his retirement. ${ }^{161}$ "Week in, week out, they [foreigners] come by the thousands-in buses, on foot, in cars, by bicycle," and learn that the U.S. spent far more of herself than money in helping to free the occupied countries from their invaders." 162 It was not entirely disheartening that the relatives did not come in such large numbers, since the graves still received company. Besides, lack of relatives was a natural occurrence. As time passed, fewer and fewer next-of-kin lived to visit. In 1961, forty-three years had gone by since the guns of August fell silent. It was not as if no interest from relatives existed. The Times stated that families at home remembered their dead in ways other than personal visits. American superintendents at cemeteries stayed busy answering correspondence, taking photographs of graves, and laying wreaths at the request of families on important dates. ${ }^{163}$

More concerning to the $\mathrm{ABMC}$ was the increasing stress placed on its mission from Washington due to funding issues. Beginning in the early 1960 , the State

\footnotetext{
158 “60,477 Graves Mark U.S. Gift to Free France," November 11,1962, The New York Times, in Proquest Historical Newspapers.

159 Ibid.

160 Ibid.

${ }^{161}$ Thomas North, One Soldier (Washington, DC: Unpublished, Undated), III-13. Permission to use granted by the ABMC Public Affairs Office, Fall 2014.

162 North, One Soldier, III-13.

163 "60,477 Graves Mark U.S. Gift to Free France," November 11,1962, The New York Times, in Proquest Historical Newspapers.
} 
Department began making plans to sell valuable Parisian real estate owned by the United States Government to purchase more housing for the growing cadre Washington bureaucrats overseas. ${ }^{164}$ One property eventually placed on the auction block was the office of the ABMC. In 1967-1968, the ABMC's traditional Paris office was sold. 165 The sale brought the government a fine profit, but Thomas North lamented that "this marked the end of an era for the Commission." ${ }^{166}$ Since the end of the Great War, the ABMC's office was an American landmark in Paris where relatives frequently arrived to receive a welcome and directions to their loved one's grave. ${ }^{167}$ With public knowledge of declining numbers of relatives visiting, segments of Congress felt that the United States need not maintain such a prominent office for the ABMC. North saw the closure as a "serious loss to the veterans and relatives of the dead. ${ }^{168}$ De Gaulle's withdraw from NATO was convenient for the ABMC's eviction. The Commission took over the vacant offices of Belgium's NATO headquarters in Garches, a western suburb of Paris. This building was much more isolated than their downtown location and lacked public transportation. ${ }^{169}$ North's bleak assessment of the ABMC's eviction by the State Department was not entirely fair. Staff members from the ABMC visited Paris during the move and found the U.S. Embassy more than willing to work with them. The Embassy realized that it was important for next-of-kin to have an accessible location to gain information about American cemeteries in France. Downtown Paris was obviously the best location for this. The American Embassy agreed to give the ABMC a room

\footnotetext{
164 North, One Soldier, IX 19-20.

165 Ibid.

166 Ibid.

167 Ibid.

168 Ibid.

169 Ibid.
} 
"furnished and equipped in an attractive dignified manner" with two ABMC staffers present to receive pilgrims. ${ }^{170} \mathrm{ABMC}$ inspectors recommended that its Paris office consider sending Pershing's old furniture to the embassy reception room to keep the attachment to history present and impress visitors. ${ }^{171}$ Despite North's dismay over the ABMC's move, the Commission's inspectors actually felt that the new arrangement was superior to past procedure. ${ }^{172}$ It was not as if the U.S. Embassy totally abandoned the work of the ABMC in Paris. Allowance for prime space in their building demonstrated that the Commission's work retained value in the period of heightened antiAmericanism.

The primary value that the ABMC's work in France had is visible in letters from families who interacted with the ABMC. During the height of the 1966 NATO controversy, the sister of a deceased WWII veteran visited France to see her brother's grave. Throughout her trip, the ABMC served as her primary point of contact. She wrote to the ABMC after returning home imparting her belief that they "performed a tremendous public relations job for the United States Government."173 Many times in her trip, Frenchmen related to her that they frequently heard of the ABMC's good deeds. Additionally, for many American tourists and French, the ABMC was the face of the United States. ${ }^{174}$ This was a good thing, in her opinion. The positive work of the ABMC helped create a favorable view of the entire American government.

170 "Report to the Chairman by Messengers McGinnis and Johnston on their Trip to Europe," July 17, 1967, Boxes 1-2, Meeting Minutes, Records of the ABMC, RG 117, NARA.

${ }^{171}$ Ibid.

172 Ibid.

173 Elizabeth McCartney to Thomas North, June 8, 1966, Box 86, European Office Files, Records of the ABMC, RG 117, NARA.

174 Ibid. 
The ABMC struggled to remain relevant in the American culture through the 1960s, despite positive feedback from visitors. Reflecting on the 1960s, Thomas North saw the start of a decline. The ABMC casted a world-wide net and oversaw regular activities abroad. Still, beginning in the 1960s, "the Commission received little publicity. .. no provision for public information was set-up."175 Most of the agency's public affairs work moved from a professional's desk to side-work for the ABMC staff. ${ }^{176}$ Yearly, the Commission found itself pressured to "reduce cost."177 North described the staffers as facing so many hardships through the 1960s that the only ones who remained did so because they personally saw their mission as a "labor of love." 178 With fewer resources, the Commission continually worked to show its face to the public. This did not always succeed, however. The ABMC's third chairman, General Jacob Devers, attempted to breathe new life into the agency by "cleaning house to revitalize the staff" in 1968.179 Part of this revitalization included persuading General North to relinquish his position as Secretary. ${ }^{180}$ North had worked with the ABMC since the end of the Great War, and Devers felt it was time to move the Commission into a new era. Devers also tried to bring the $\mathrm{ABMC}$ more into the American consciousness at home. $\mathrm{He}$ personally called on President Kennedy to have the U.S. Postal Service release an ABMC stamp to coincide with their dedication of its Honolulu memorial. ${ }^{181}$ Kennedy's aid responded to the request in the negative. He explained to Devers that only fifteen

\footnotetext{
175 North, One Soldier, IX 25.

176 Ibid.

177 North, One Soldier, IX-3.

178 Ibid.

179 William Jones, "Service with the American Battle Monuments Commission, April 1, 1967 to June 30, 1974," undated, Box 1, William Jones Papers, ABMC Folder, USAHEC, Carlisle, 3. 180 Ibid.

${ }^{181}$ Ralph Dungan to Jacob Devers, July 18, 1963, Box 204, Entry 201, White House Files, JFK Papers, JFK Library, Boston.
} 
special stamps were released per year and that the ABMC technically already had a stamp in 1945-46 when a series of stamps commemorating sacrifices of all branches of the services was released. ${ }^{182}$ The ABMC's request went to the USPS, but it was one of many in a "tremendous backlog," and had little chance of moving up the list. ${ }^{183}$ The Commission fought to keep its overseas staff numbers at 440, but in 1968 the "axe fell" and large personnel cuts went into effect. With a costly war in Vietnam, funds needed to go towards living military personnel more so than the dead. ${ }^{184}$

A reduction of budget and personnel was not the biggest problem that the ABMC faced through the 1960s. The ABMC's greatest struggle was for its very life. Beginning with the $89^{\text {th }}$ Congress (1965-66), and in each successive Congress through the 1960 , House representatives introduced bills which would establish a National Cemetery System within the Veteran's Administration." 185 These bills varied in content, but many iterations of them called for the dissolution of the American Battle Monuments Commission, in favor of administration from a centralized Veteran's Administration overseeing all national cemeteries. The practical reason for consolidating all national cemeteries under the umbrella of one government agency stemmed from budget concerns. Increasing demand for burial in national cemeteries created by the elderly generation of WWII veterans and Vietnam casualties also drove consolidation arguments. Threat of abolishment forced the ABMC to articulate its importance to the United States and distinguish what made it unique among other national commemorative agencies. The political debate over the continuation of the ABMC

\footnotetext{
182 Ibid.

183 Ibid.

184 North, One Soldier, IX-3.

${ }_{185}$ ABMC Secretary A.J. Adams, untitled, undated, Box 1, Legislative History, Records of the ABMC, RG 117 , NARA.
} 
revealed the dual impulses within the United States to continue holding American memory of the World Wars abroad in special reverence, and the move forward from its strong military connections.

Republican Senator John Saylor from Pennsylvania stood out as one of the most vocal opponents of ending the AMBC. Saylor was a World War II veteran, yet as a member on the House Special Subcommittee on Cemetery Affairs, he displayed a belief that the United States needed to stop bowing to the whim of the World War II generation simply because of their popular memory. In his questioning of the Assistant to the Director of Veterans Affairs, Saylor resented that leadership in the Veterans Administration lacked the "backbone" to take a definitive stance on the ABMC's worth. ${ }^{186}$ Saylor asked the assistant "why continue the Battle Monuments Commission and their expenditures if you can turn it all over to the Veterans Administration, and one administration?"187 He received no direct response to this inquiry. Thus, Saylor concluded that the ABMC retained a special status just because it had a couple old generals and admirals on it, that former President Eisenhower showed interest in the Commission because of his early career work on it, and finally because many of its present members were Eisenhower appointees. ${ }^{188}$ These historic factors did not make the ABMC an agency that Congress "cannot touch," in Saylor's opinion. ${ }^{189}$ Ending the Commission would benefit the American people by saving the federal government money and stopping "a few generals from taking a trip around the world twice a year." 190

\footnotetext{
${ }^{186}$ Comments of Representative John Saylor (R-PA), “"Questioning of Mr. Robert Lynch, Special Assistant to the Director National Veterans Affairs before the Special Subcommittee on Cemetery Legislation, November 19, 1970, Box 1, Entry 47, Legislative History, Records of the ABMC, RG 117, NARA. 187 Ibid.

188 Ibid.

189 Ibid. 190 Ibid.
} 
A representative from the $\mathrm{ABMC}$ was not present during the questioning when Saylor delivered his critical assessment. Reading the transcript caused alarm in leadership of the Commission, however. The ABMC's new Secretary, A.J. Adams felt that Saylor had malicious intent to "eliminate the Commission for no other reason than personal pique." 191 Saylor's biggest irritation seemingly stemmed from resentment over retired generals travelling to $\mathrm{ABMC}$ sites on funding from American taxpayers. Regardless of Saylor's motives, ABMC Secretary Adams and new Chairman Mark Clark waged an offensive war to keep their Commission alive. Reduction of personnel, budget cuts, anti-Vietnam protest, and lax commemorative ceremonies all signaled shifting public perceptions of the value of the ABMC's memory within America and France. Leaders in the ABMC needed to respond to these changes if they wanted the Commission to survive into future.

The ABMC defended itself primarily using two arguments. The first one was more superficial and dealt with cosmetics and the demanding nature of maintaining ABMC sites. The ABMC's total budget was a miniscule compared to the Veterans Administration. Its absorption into such a large agency would, inevitably, dilute the "detail and personal attention it now receives from the Commissioners and their small staff." The "level of maintenance would surely decline and cost would go up" under the VA. ${ }^{192}$ Leaders in the ABMC did not want the erosion of their high standards. One engineer noted that “in comparison with ABMC's cemeteries, Arlington Cemetery is a

\footnotetext{
${ }^{191}$ ABMC Secretary A.J. Adams, untitled, undated, Box 1, Entry 47, Legislative History, Records of the ABMC, RG 117, NARA.

192 "Report of the U.S. Veterans Advisory Commission on the Veterans Benefits System," undated, Box 1, Entry 47, Legislative History, Records of the ABMC, RG 117, NARA.
} 
weed patch." $193 \mathrm{He}$ did not want sacred American sites throughout the world to fall into disrepair because of DC politics.

More important to the ABMC's quest for survival was articulating its significance to American culture at home and abroad. Chairman Mark Clark wrote Senator Strom Thurmond, a member of the Senate Committee on Veteran Affairs to explain the broader importance of the ABMC to the United States. "Each year more than three million Americans and foreigners visit the Commission's cemetery memorials abroad," Clark explained. The ABMC gleaned from public feedback that their sites created "more real understanding of the friendship among the people of the countries in which they are located than any other of our governmental activities."194 Clark also personally wrote John Oakes, the editor of the New York Times in hope that he would print a personal appeal from the ABMC to its world-wide subscribers. Clark firmly believed that "it would be a serious mistake to abolish the ABMC" and end its "high purposes" of bringing "credit upon the United States"195 Furthermore, Clark reasoned that the ABMC should not even be considered for consolidation with the VA because it maintained not "cemeteries," but "shrines that keep alive the memories of thousands of young men who gave their lives in two world wars on foreign soil." ${ }^{196}$ These shrines long ago ceased to be places for future burial, so it made no sense to lump them into a large federal cemetery system.

\footnotetext{
193 William Jones, "Service with the American Battle Monuments Commission, April 1, 1967 to June 30, 1974," undated, Box 1, William Jones Papers, ABMC Folder, USAHEC, Carlisle, 5. 194 ABMC Chairman Mark Clark to Senator Strom Thurmond," undated, Box 1, Entry 47, Legislative History, Records of the ABMC, RG 117, NARA.

195 Gilmore D. Clarke to John B. Oakes, February 17, 1969, Box 1, Entry 47, Legislative History, Records of the ABMC, RG 117, NARA. 196 Ibid.
} 
The Veterans Affairs investigative committee tasked to study the issue came to agree with the ABMC's argument. Investigators found ABMC memorial cemeteries to be "a source of pride and inspiration to Americans and foreigners alike." "More than a million foreigners and thousands of Americans" annually visited these sites. ${ }^{197}$ Diplomatically, the committee also found value in ABMC cemeteries. "Foreigners are reminded of our nation's respect for its honored dead and the supreme sacrifice made by so many Americans for their freedom and well-being." The committee concluded that "there is probably no other program or activity which promotes more sympathy, understanding and friendship for the United States among the people of the countries where the memorials are located." 198 Representatives from the French equivalent of the ABMC also came to the Commission's aid reporting that France stood alone among Allied countries for having a centralized commemorative agency for their war cemeteries. The head of French military cemeteries and memorials warned the ABMC that he tirelessly attempted to "completely divorce" his commission from the French Ministry of Veterans Affairs because a "monuments and cemeteries commission could only succeed as "a separate entity under the highest authority of state."199

The ABMC proved its value to the United States and thwarted Congressional attacks by explaining that their sites no longer met the definition of cemetery, but stood as eternal monuments. Chairman Mark Clark's argument that the ABMC's "closed cemeteries should be maintained in perpetuity as national shrines" won the day. ${ }^{200}$

\footnotetext{
197 "Report of the U.S. Veterans Advisory Commission on the Veterans Benefits System," undated, Box 1, Entry 47, Legislative History, Records of the ABMC, RG 117, NARA.

198 Ibid.

199 G.M ver Hult to General A.J. Adams, March 3, 1969, RG 117, Legislative History, Box 1, NARAII. The French head of cemeteries and memorials cited was Admiral Galleret.

200 Mark Clark to Strom Thurmond, February/March 1971, Box 1, Entry 47, Legislative History, Records of the ABMC, RG 117, NARA.
} 
The ABMC sites ultimately held too much national importance to be passed into the massive Veteran's Administration where they could not get the personal care required to maintain them. ${ }^{201}$ By framing their cemeteries in this light, the ABMC froze them in time. No soldiers from other wars would ever lie with American World War dead abroad. Nor would any soldiers in ABMC cemeteries be reinterred and shipped back to American soil, except in extremely special situations. The ABMC received requests for repatriations throughout the twentieth century but held firm to its commitment of 'closed cemeteries.' All of the bodies that the ABMC cared for came to them only after next-of-kin decisions, or because no family existed to speak on the dead's behalf. Also, the Commission felt that "host countries would not tolerate" repatriation of American bodies and it did not want unsightly gaps in its shrines where permanent graves once stood. ${ }^{202}$

The ABMC's argument for its continuation seemingly disconnected it from the turbulent wars and prioritized the memory of American remains from the World Wars abroad in the national consciousness. Yet, after surviving the onslaught, ABMC leaders adopted proactive measures to make sure the government and American public found the Commission relevant. The Commission also found a friend in President Richard Nixon. The federal attack against the ABMC began under the administration of liberal president Lyndon Johnson and ended in the Nixon administration. General Mark Clark, a decorated WWII General and NATO commander in the Korean War, was Nixon's appointee to replace Devers and lead the ABMC. Once Clark successfully led the ABMC through its Congressional attack in the late 1960s, he threw his support to President

201 Ibid.

${ }^{202}$ North, One Soldier, III-9-10. 
Nixon's escalation of the Vietnam War. Clark found an ABMC ally in President Nixon, and Nixon saw the usefulness of the ABMC in improving declining moral among Americans over Vietnam.

In May of 1970, General Clark demonstrated to President Nixon that the ABMC fully supported the war in Vietnam and saw American sacrifice in Indochina in the same light as the World Wars. Clark wrote to Nixon on behalf of the entire ABMC "to fully support you on the selfless and courageous action you have taken in the Cambodian situation in protect our heroic men in Vietnam and preventing a communist take-over in South East Asia." 203 This support came at a time when many other Americans showed dissatisfaction that Nixon was actually expanding the Vietnam conflict in other countries instead of bringing the 'peace with honor' he promised. Clark viewed Nixon's expansion of the war as a tribute to the American remains that the ABMC commemorated. He praised Nixon's “decisive action" for "assuring the U.S. and free world that the gallant men whose graves are in Europe will not have died in vain." 204

A meeting between General Clark and President Nixon months before at the White House foreshadowed the ABMC's pro-Vietnam support. President Nixon explained to General Clark that he firmly believed that the ABMC "cemeteries and the sacrifices of those buried in them should be an inspiration to the people of America and give them a sense of pride in our national heritage and accomplishments." ${ }^{205}$ Nixon fully supported the work of Commission and experienced many ABMC sites himself. He

203 Mark W. Clark to Richard Nixon [telegram from Nancy, France], May 4, 1970, Boxes 1-2 (FRCs), Organizations and Meetings 1968-1974, Records of the ABMC, RG 117, NARA.

204 Ibid.

205 A.J. Abrams, "Memorandum for the Record: President Nixon's meeting with the ABMC at the White House, 1500 February 16, 1970, Boxes 1-2 (FRCs), Organizations and Meetings 1968-1974, Records of the ABMC, RG 117, NARA. 
saw ABMC cemeteries as a valuable asset that could boost the morale the American people. He wanted to make sure that all ABMC commissioners fully understood the sites by visiting them all. After years of threatened budget cuts and termination, the ABMC found Nixon eager to spend on the Commission's behalf. He assured Clark that even though the ABMC did not have $\$ 30,000$ budgeted for a trip to send commissioners abroad, that "sum should be available from some place." ${ }^{206}$ He immediately tasked an assistant to find the money. Nixon also felt that the military should provide the ABMC a plane to make cemetery visits and desired that Clark and other commissioners visit American troops in Vietnam.207 Inspired by Nixon's enthusiasm, Clark suggested that the ABMC release a film to the American public "showing our installations and the story behind them." ${ }^{208}$ Nixon loved the idea and suggested that Clark work with the United States Information Agency to obtain the equipment and personnel needed to make such a product. ${ }^{209}$ Clark left the White House an inspired leader. He urged Secretary Adams to immediately work on acquiring a Defense Department aircraft to visit ABMC sites and the battlefront. ${ }^{210}$ He also moved to develop a committee to decide the best means "of informing the public about the ABMC and arousing the public's interest in the deeds and sacrifices of those buried overseas." ${ }^{211}$ No longer a Commission fearing elimination, the $\mathrm{ABMC}$ now viewed itself as the government agency most qualified to "create in our

\footnotetext{
206 Ibid.

207 Ibid.

208 Ibid.

209 Ibid.

${ }^{210}$ A.J. Adams, "Memorandum for the Record: Conference with General Clark in his room at the Madison Hotel after meeting with the President Monday afternoon," February 17, 1970, Boxes 1-2 (FRCs), Organizations and Meetings 1968-1974, Records of the ABMC, RG 117, NARA. 211 Ibid.
} 
citizens a greater sense of patriotism and pride in our national heritage and accomplishments." ${ }^{212}$

General Clark and the rest of the ABMC commissioners used a Defense Department plane to make two inspection trips in 1970 after the Nixon meeting. Their first tour was of the European cemeteries. Clark reported to Nixon in June 1970 that the trip was successful and that all ABMC travelers acted "as emissaries of good will and friendship to the citizens of the countries in which our cemeteries and monuments are located" just as Nixon had "cautioned us to act.”213 Clark's observances of foreigners at ABMC cemeteries assured him that he led the government office that "created more respect, understanding, good will, and friendship for the United States than any other." ${ }^{214}$ Clark's biggest concern after the first inspection tour was that the ABMC currently maintained an unbalanced "commemoration of the deeds of our armed forces.”215 The Korean War had no memorials, nor Vietnam. Clark would think more on this unbalance in his next tour of the ABMC's Pacific region assets and visit to Vietnam. ${ }^{216}$ Nixon appreciated the feedback that Clark gave him. It warmed his heart that "people still cared and remembered" the American dead on foreign soil. ${ }^{217}$

General Clark made his inspection tour of the Pacific region through the first month of 1971. He visited Hawaii, the Philippines, South Korea, and Taiwan. He met with the leaders of each country and was impressed with their knowledge of the ABMC's

\footnotetext{
212 Ibid.

${ }^{213}$ Clark to Nixon, June 15, 1970, Box 3, Folder 1, White House Subject Files, FG 73 ABMC, Nixon Papers, Nixon Presidential Library, Yorba Linda, CA.

214 Ibid.

215 Ibid.

216 Ibid.

${ }_{217}$ Nixon to Clark, July 23, 1970, Box 3, Folder 1, White House Subject Files, FG 73 ABMC, Nixon Papers, Nixon Presidential Library, Yorba Linda, CA.
} 
mission. ${ }^{218}$ Through Clark's interaction with foreign leaders, he saw a need for an American memorial in South Korea to sustain their development as a "strong and faithful ally of the United States." 219 The tour also included a stop to Vietnam for the ABMC leadership to hear from U.S. commanders how the war was going. This trip was seemingly intended to boost morale and plant the seed for future Vietnam commemoration. Nixon was again pleased that his new ABMC members could travel abroad and do diplomatic work for him. He thanked Clark for examining the "means for emphasizing and strengthening the bonds which unite us to allied and friendly Asian nations," and for "conveying to them the goodwill of the U.S." 220 The ABMC's Fiscal Report for 1971 clearly imparted a feeling that the Commission played a role in U.S. diplomatic relations and desired to start commemorating "the Korean War, and ultimately the War in Viet Nam.”221

It took three years to make the ABMC film that Clark and Nixon envisioned. The goal of The Price of Freedom was to make the "nation devote more effort and attention to regaining and maintaining the splendid spirit in which this nation was born."222 This order came directly from President Nixon himself. He wished the ABMC to "influence the news media, which gives too much attention to the unruly minority who are violating our laws at will while not placing proper emphasis on the often forgotten virtues of Duty, Honor, and Love of God and Country."223 Clearly, Nixon saw that the

\footnotetext{
218 "Annual Report for Fiscal Year, 1971," (Washington, DC: ABMC, 1972), Box 3, Folder 3, White House Subject Files, FG 73 ABMC, Nixon Papers, Nixon Presidential Library, Yorba Linda, CA, p. 28.

219 Ibid.

220 Ibid., 30.

${ }^{221}$ Ibid., 2.

${ }^{222}$ Clark to Nixon, June 15, 1970, Box 3, Folder 1, White House Subject Files, FG 73 ABMC, Nixon Papers, Nixon Presidential Library, Yorba Linda, CA. 223 Ibid.
} 
ABMC's role of caretaker of the dead made it a powerful manipulator of public opinion. The film debuted to the American public in 1973. It represented the ABMC's attempt to provide information on its history and the cultural value of its sites abroad. The film's release after the Congressional attacks on the $\mathrm{ABMC}$, and the narrative of the film, portrayed the ABMC as a national treasure. Clocking in at just under a half-hour, The Price of Freedom explained the long tradition of American military sacrifice to its viewers and the ABMC's mission to preserve this sacrifice for perpetuity. Script writers packed a grand military narrative into the short running time.

The Price of Freedom endeavored to show an unbroken link between ancient Greek culture and contemporary U.S. military conflicts. It began with the Greek battle at Marathon and the Greeks' immediate efforts afterwards to create a monument that reminded how the preservation of freedom required "willingness to pay the price."224 The ABMC portrayed itself as a successor of the Greek monument makers. It was the Commission's mission to "erect memorials to honor the men who died for their country, so the living whose hearts were seared by their death could appreciate them." ${ }^{225}$ With this ancient link established, the film progressed through a hyper-patriotic narrative of U.S. wars from the American Revolution onward. It noted that although the fighting spirit of the American soldier won wars, great men dominated commemorations in the first century of the republic-George Washington, Abraham Lincoln, Ulysses Grant, and Robert E. Lee were legendary men whose memory society cast in stone to "keep something alive and guard the land.”226 It was not until after World War I, and the

\footnotetext{
224 The Price of Freedom (Washington, DC: ABMC, 1973), RG 117, Video Recordings Branch, NARA; 225 Ibid. ${ }^{226}$ Ibid.
} 
creation of the ABMC, that "everyman would be accounted for, no one forgotten." 227 The ABMC ennobled all American military dead, and its Chairman, General Clark, who during World War II asked Italy only for "enough soil to bury his gallant” during his offensive through the country epitomized the sanctity of the Commission.

The film utilized personal reflections from individuals to highlight the ABMC's importance to the American people. General Clark explained that, as Chairman, he wanted to "focus the attention of the people back home to the great price they [the dead] paid so we can enjoy the blessings of freedom." ${ }^{228}$ Clark delivered his message in a poised and humble way. The next interviewee was a Frenchwoman speaking from Suresnes Cemetery. She recollected Americans entering Paris during World War II and the "crazy" reception they received from appreciative French. This interview provided viewers the perspective of someone in France who appreciated the United States and showed the goodwill that ABMC cemeteries created between nations. The final interview included references to Vietnam and brought the ABMC's work into the present. That Pacific perspective came from a Japanese-American that fought with the famed $442^{\text {nd }}$ Regiment in the Pacific Islands during WWII. The veteran was interviewed at the ABMC's Pacific memorial at the Punchbowl Cemetery. The film's narrator noted that this memorial honored not only the Pacific theater of WWII, but also the Korean War. It signified that after WWII, the U.S. assumed leadership of the free-world and carried these responsibilities into Korea and Vietnam. The Japanese-American veteran related to the audience that he visited the cemetery not only to honor his WWII comrades, but also men from his unit currently dying in Vietnam. ${ }^{229}$ Following this

\footnotetext{
227 Ibid.

228 Ibid.

229 Ibid.
} 
interview, the narrative shifted to President Nixon's quest to build a lasting peace in the world. The scene faded out to the all too familiar sounds of military airplanes and helicopters associated with the Vietnam War.

The Price of Freedom is not a film easily accessible today. No copy exists among the ABMC's institutional collection. To contemporary viewers, the film very much comes across as a conservative leaning pro-Vietnam film. It is not known how the American public received the film. Nixon and his staff found it to be "a truly inspirational presentation." ${ }^{230}$ At the very least, The Price of Freedom briefly placed the ABMC back into the public eye. American sacrifices in Vietnam also found a firm linkage to the World Wars through the video production.

The Vietnam War seems to be the root of much of the ABMC's trouble in the 1960s. Through the twentieth century, the ABMC had a clear role in American culture as the caretaker of military remains abroad. Through the Cold War, the United States reverted back to its pre-World War I policy of total repatriation. In America's Asian wars the dead did go home, and the government took painstaking steps to ensure that the number of unknowns and missing in actions remained as low as possible. The motives for this decision are visible in ABMC debates about commemoration in the Pacific. Japanese islands were remote, represented unfriendly soil, and a small chance existed that considerable numbers of Americans would visit graves left behind. A cemetery without visitors was merely a cemetery, and not a site of public memory that ABMC cemeteries were. There was little chance in the political atmosphere of the Cold War of placing large ABMC cemeteries in an unstable Korea or Vietnam. The new

${ }^{230}$ Richard Lawson to General Clark, October 24, 1973, Box 3, Folder 4, White House Subject Files, FG 73 ABMC, Nixon Papers, Nixon Presidential Library, Yorba Linda, CA. 
attitudes towards American peripheral wars also altered the ABMC's role as the agency responsible for commemorating the sacrifices of all American armed service members in foreign wars. How would unpopular wars in Asia be commemorated? The length of American commitment in Vietnam meant that throughout the sixties there was no completed story to work from. It is also notable that in both World War I and World War II, cemeteries acted as the focal point of all ABMC commemoration. Without soldier dead to care for, the ABMC's commemoration of the Asian wars decreased dramatically. Their official commemoration of Korea and Vietnam was essentially tacked on to the Honolulu Memorial at Punchbowl Crater in Hawaii. The names of the missing in Korea and Vietnam and maps of significant battles in both wars gained placement alongside similar commemoration to the Pacific theater in WWII.231 These additions evolved much slower and in a more laborious process than World War commemoration. The ABMC's Vietnam memorial pavilion did not join monuments from other Pacific conflicts in Hawaii until 2012.

${ }^{231}$ One could likely make the argument that American memory is simply less concerned with what happens in regions that are traditionally unfamiliar to us. For most Americans memories of World War II deal with Normandy, France, Germany, Hitler, and concentration camps. Memories of the Pacific generally focus around the iconic Iwo Jima photograph, or the controversies surrounding the Atomic bomb. The ABMC's decisions to not locate any permanent cemeteries in the Pacific, aside from the Philippines, reflect the lack of enthusiasm regarding a strong Pacific memory. This is mirrored in Korean and Vietnam commemoration. 


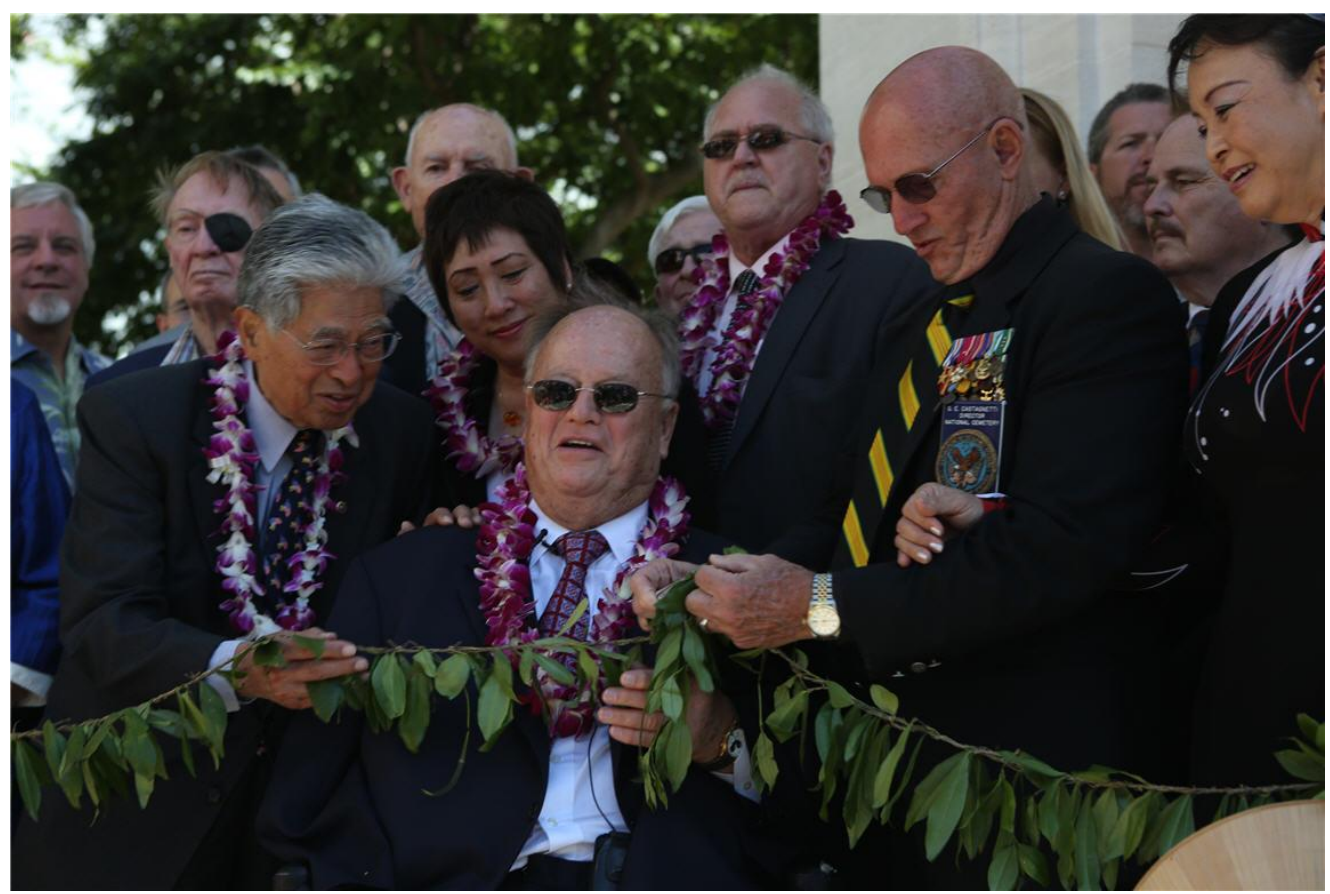

Photo 6.2: Honolulu, Nov. 11. 2012 - Flanked by Vietnam War veterans, Senator Daniel Akaka, Congresswoman Colleen Hanabusa, American Battle Monument Commission Secretary Max Cleland untie a "maile lai" officially dedicating the new Vietnam War pavilion at the Honolulu Memorial following the annual Veterans Day ceremony at the National Memorial Cemetery of the Pacific on Sunday. The new Vietnam War pavilion combined with the already existing Vietnam War Courts of the Missing at the Honolulu Memorial constitute the only federal memorial to veterans of the Vietnam War built solely with federal. Source: ABMC.gov (Official American Battle Monuments Commission photograph).

\section{$\underline{\text { Conclusion }}$}

The 1960 s marked the start of a transitory period for the American Battle Monuments Commission. The epoch of the World Wars was over. Its replacement was a Cold War defined by ideological battles, fear of nuclear holocaust, and proxy wars. Contemporary issues proved more pressing to the living than memories of victories past. France, the United States' eldest European ally, and gateway to the continent seemed, increasingly unfriendly under President de Gaulle's leadership. All of this put the ABMC 
in a precarious position. The Commission was the protector of the past and caretaker of American remains from a bygone era. For the first time since its creation in 1923 , the ABMC found that it needed to prove its national value. Limited and controversial wars signified an end to new ABMC cemeteries. This meant that the ABMC needed to walk a fine line. The Commission had make sure that Americans and foreigners still found value in its cemeteries. Leaders of the ABMC in the 1960 s worked to prove their relevancy. It appears that the ABMC's efforts worked by the start of the 1970s. Their reports in 1971 and 1972 indicated that attendance at major ceremonies across Europe went in "excess of previous years." 232

Military remains in Europe were simultaneously frozen in time and used as a bridge to the past and present. American dead from the World Wars stood out in speeches and public relations projects as signifiers of American friendship to foreign nations, reminders of a golden period of friendship. No matter what the international situation, these dead represented a specific period. At the same time, when needed, the memory of the dead also served as a means to link the past and present. American leaders saw the remains of their military dead as an effective medium to show foreigners and Americans alike consistency in its military demands. Thus, the 1960 s placed a fork in the road of the ABMC. One path kept the memory of its remains safely anchored in friendly past. The other placed the same remains within the contentious new wars in the Third World. Throughout the 1960s, American leaders waffled on which road the memory of its Great War and World War II dead would take. In the end, the fork did not lead to two distinct destinations. It instead sporadically intersected. President

232 “Annual Report for Fiscal Year, 1971," (Washington, DC: ABMC, 1972), Box 3, Folder 3, White House Subject Files, FG 73 ABMC, Nixon Papers, Nixon Presidential Library, Yorba Linda, CA, p. 28. 
Woodrow Wilson rocketed the United States toward a strong international presence when he committed American soldiers to the European battlefields of World War I. Since that moment, American military dead of now tranquil battlefields could simultaneously portray a revered era, or speak to a specific contemporary circumstance. This pliability still exists today. 


\section{Conclusion: Contemporary Uses of U.S. Memory Abroad}

American and French leaders turned to the memory of American military remains buried in French soil to address existing political situations throughout the twentieth century. Political regimes changed, diplomatic situations altered, and the public perception towards their own nation and others shifted. Throughout all of the flux, the presence of American bodies remained a constant. They retained an unbroken vigil for interests of the United States abroad. Although dead, they were far from silent. The living provided them a voice. The public assigned meaning to their sacrifices, validated their memories, and showed respect for them even during the most chaotic periods in France. Even though the dead permanently occupied the same soil for perpetuity, they were not inert. Their memory lived and evolved with the times. The way the living interacted with the American dead shaped the memory of their war and motives for fighting. Now, in the present era, do these remains still have cultural meanings? Are the American bones of World War I and World War II in Europe still relevant to generations who did not live through their deeds? Do they still fulfill a diplomatic purpose?

At the time this work was written in 2014, all American veterans of the Great War have died. The final American doughboy, Frank Buckles, passed on at age 110 in Charles Town, WV the same town where this work was penned. ${ }^{1}$ Each day while writing, the author paused countless times to watch traffic move along the Frank Buckles Memorial

\footnotetext{
${ }^{1}$ Richard Goldstein, "Frank Buckles, Last World War I Doughboy is Dead at 110," The New York Times, February 28, 2011, online edition at http://www.nytimes.com/2011/03/01/us/o1buckles.html? r=0, accessed May 5, 1014.
} 
Highway. While no American veterans remain to pass on their lived memory of the Western Front, thousands of American WWII veterans live on as relics from one of the most revered periods of their nation's past. They too are rapidly disappearing from the ranks of the living, however. An article from late 2013 estimated that some 640 American veterans from the Second World War die each day. ${ }^{2}$

This conclusion seeks to understand if the American memory of the World Wars still has relevance in American culture today. The Cold War ended in the early $1990 \mathrm{~s}$ and the weight of fighting communism lifted from American war dead buried in Europe. But, with the fall of the USSR could they now rest in peace, or did they have other battles to fight? This conclusion will analyze how U.S. leaders have engaged with the memory of World War I and World War II dead abroad following the Cold War. It will end by analyzing the U.S. Federal Government shutdown that occurred in Fall 2013.

An exhaustive march through political uses of American military remains for the latter part of the twentieth century is not necessary for this conclusion. Each year, American and French leaders gather at American military cemeteries on solemn days and give a voice to the dead. This voice refracts the international concerns of the moment and anchors solutions to current problems in reinterpretations of the past. For instance, President Ronald Regan's famous “The Boys of Pointe-du-Hoc” speech delivered in Normandy on the $40^{\text {th }}$ anniversary the invasion looked to D-Day to provide context to the four decade long Cold War. Reagan spoke directly to the Soviet Union in his speech commemorating American military valor. He reported that America was "prepared to reach out again in the spirit of reconciliation" and that there was no

\footnotetext{
2 Kathleen Parker, "Closing Memorials was a Monumental Mistake," The Kansas City Star, October 6, 2013, online edition http://www.kansascity.com/2013/10/06/4529997/closing-memorials-was-amonumental.html, accessed October 15, 2013.
} 
"reconciliation welcome more than one with the Soviet Union."3 President Reagan acknowledged that staggering sacrifices that the Russian people made in World War II for the Allied cause. He hoped that the Soviets could learn from their military dead the lessons that the United States and NATO partners had from their own dead. Reagan promised the Soviets that the West "does not want war" and was ready to "seize the beachhead of peace." 4 Each day citizens of the West prayed that the Soviets might abandon desires for conquest and change for the better. 5 The change did not happen immediately, but took place before the next major D-Day anniversary.

Ten years later, President Bill Clinton traveled to Normandy to commemorate the $50^{\text {th }}$ anniversary of D-Day and articulate his own foreign policy agenda on an international stage. Americans closely scrutinized Clinton's engagement with the memory of American WWII remains. Those who lived through WWII viewed him as a member of a "selfish generation" unwilling to sacrifice for their nation. ${ }^{6}$ Clinton was not known as a strong supporter of the military, he himself had dodged the draft during the Vietnam War. Veterans feared that a leader such as Clinton would fail to properly commemorate American sacrifices in World War II. Instead of perpetuating a message of heroism his words might diminish their glory.7 Clinton and his staff took the commemorative trip seriously and saw its political uses. Despite being uncomfortable with "military flag waving," Clinton spent weeks learning the history of D-Day and

3 Ronald Reagan, “The Boys of Pointe-du-Hoc,” June 6, 1984, available in full text from http://www.historyplace.com/speeches/reagan-d-day.htm, accessed May 8, 2014.

4 Ibid.

5 Ibid.

${ }^{6}$ William Drozdiak, "Veterans See Commander in Chief in New Light," The Washington Post, June 7, 1994, p. A1.

7 Ronald Reagan, "The Boys of Pointe-du-Hoc." 
drafting speeches. ${ }^{8}$ His goal was to make veterans and the current American service members see him in a "new light." 9 Feedback from veterans following Clinton’s D-Day speech showed that Clinton succeeded in his mission. Washington Post writers reported "almost universal praise" from veterans towards Clinton's words. He showed sincerity, understanding, respect, and genuine emotion when addressing the memory of American WWII dead. Clinton cast his generation as the children of World War II sacrifice. He respected the sacrifices of the aging WWII generation, but assured them that "they did their jobs, [now] we must do ours." 10 The problems of the 1990 os were far different than those that rocked the world in 1944. Americans learned from the sacrifices of World War II and moved forward with their memory in mind. The Cold War was over, and America's enemies no longer revealed themselves so clearly. The United States no longer could apply unlimited military force, nuanced diplomacy and partnerships were the only way to protect America's national security. ${ }^{11}$ Veterans present for Clinton's $50^{\text {th }}$ anniversary speech not only engaged with the past, but left with better understanding of the future. One veteran admitted that "we are all beginning to understand this is a different era." Another left Normandy knowing that "it is an entirely new world than the one that came into being after the war we fought."12 The stakes of this new world became much clearer during the presidency of Clinton's successor, George W. Bush.

8 Peter Grier, “Clinton Draws on WWII Lessons," The Christian Science Monitor, May 31, 1994 in Proquest Historical Newspapers.

9 Ibid.

10 Ibid.

${ }^{11}$ Ibid.

12 Ibid. 
The terrorist attacks against the United States on September 11, 2001 made "everything different now."13 Much of the difference came from the leadership decisions of President George W. Bush. Following the Al-Qaeda attacks, the United States immediately deployed troops to Afghanistan to punish those responsible for the attacks and dismantle Islamic terrorist groups. NATO and UN countries joined the United States in Afghanistan providing both assets and military personnel. International support for the United States in Afghanistan demonstrated that most countries believed that military force was justified. The 2001 invasion turned into a prolonged insurgency war, and in 2014, troops are still fighting in Afghanistan. Thousands of Americans have lost their lives in the conflict and tens-of-thousands more left the theater maimed.

While allied nations supported the United States led war in Afghanistan, President Bush's second theater of the War on Terror, Iraq, faced major international criticism. President Bush's foreign policy agenda in his first term evolved into hybrid plan adopting new and old aspects of American methodology. His rhetoric for waging war on Islamic terrorists was based firmly on his Christian faith and belief in democracy. Perhaps more than any other twentieth century U.S. President, Bush espoused the idealism of progressive President Woodrow Wilson. ${ }^{14}$ Bush also brought the United States back into the ideological battle of the recently ended Cold War. At the start of the new millennium, the promise of a peaceful era seemed possible for the United States. After September 11, the "red threat" of communism was replaced by the "green menace of radical "Islamo-fascism." 15 President Bush was committed to

\footnotetext{
13 Douglas Little, American Orientalism: The United States and the Middle East Since 1945 (Chapel Hill: University of North Carolina Press, 2008), xii.

14 Little, American Orientalism, xi.

15 Ibid.
} 
preventing another 9/11 and instead of following the containment doctrine of the Cold War, his Bush Doctrine relied on the preemptive 'shoot first, ask questions' later policy. ${ }^{16}$ This policy was put to the test when the U.S. intelligence alleged that Iraqi President Saddam Hussein was constructing weapons of mass destruction and harboring terrorist. In order to protect the United States, President Bush won Congressional approval to invade Iraq, overthrow Hussein's government, and install a democratic beacon in the Middle East. ${ }^{17}$ The large international coalition found in Afghanistan did not appear for Operation Iraqi Freedom. Great Britain stood as the prominent ally of the United States in this conflict. Hussein's regime quickly toppled and President Bush declared the American mission accomplished in Iraq. Building a democratic government in Iraq proved difficult, however. Radical Islamic groups joined Iraqi nationalists to force the United States out of Iraq. American troops found themselves caught in a civil war and insurgency. Approximately 5,00o Americans died in Iraq before finally withdrawing after seven years of occupation in 2011.

The international unpopularity of the Iraq War caused a spike in antiAmericanism around the world. President Bush turned to the memory of American soldiers buried abroad from the World Wars to improve perceptions of the United States in the early phases of the War on Terror. France's possession of large numbers of U.S. military dead made it one of the countries most aggressively exposed to American efforts to draw international support through popular war memories.

Throughout, this work has shown persistent manifestations of French antiAmericanism throughout the twentieth century. Though constant, French anti-

16 Ibid.

${ }^{17}$ Ibid., xii. 
Americanism is nuanced. While the French may grow angry over American arrogance, economic policy, military aggressiveness, or cultural differences; fundamental ideals from their similar revolutions remain present. ${ }^{18}$ When the United States declared war on Iraq in 2003, French President Jacques Chirac emerged as one of the loudest opponents of the war. ${ }^{19}$ This contrasted with French support for American actions in Afghanistan. President Chirac was the "first foreign head of state to arrive in New York after September 11" to pledge solidarity with the United States and a willingness to "fight America's attackers." ${ }^{20}$ At the time of the United States invasion in Iraq, French aircraft attacked Taliban outposts in Afghanistan and French soldiers took casualties alongside Americans on Afghan battlefields. ${ }^{21}$ Chirac did not see the invasion of Iraq as just, and would not commit French forces. He warned President Bush that an invasion of Iraq likely would turn into a drawn out bloody conflict. France experienced strong Arab nationalism when fighting Algerian rebels in the mid twentieth century-Chirac had even fought in that conflict. ${ }^{22}$ In Chirac's 2003 assessment, American occupation of Iraq would draw in terrorist and increase Islamic animosity towards the Western world. 23

The American public saw Chirac's refusal to support the United States as betrayal. Anti-French sentiment swept the nation shortly after the beginning of the Iraq War. American businesses dumped French wine in the streets. French fries, French

\footnotetext{
${ }_{18}$ Max Paul Friedman, Rethinking Anti-Americanism: The History of an Exceptional Concept in American Foreign Relations (New York: Cambridge University Press, 2012), 228.

19 Jerry Seper, "Graveyard Graffiti Taunts the Allies," The Washington Times, April 4, 2003, in Proquest Historical Newspapers.

${ }^{20}$ Max Paul Friedman, Rethinking Anti-Americanism, 230.

${ }^{21}$ Ibid., 228.

22 Ibid., 229.

23 Ibid.
} 
toast, and French dressing all had their despicable adjective replaced with "freedom." 24 Florida Congresswoman Ginny Brown-Waite saw French non-support for Iraq so offensive that she proposed a resolution to the House of Representatives to "remove the remains of any United States service member interred in an ABMC cemetery located in France or Belgium"25 This move mirrored the similar 1966 proposal to remove American military dead from France after de Gaulle ordered the U.S. military out of France. ${ }^{26}$ The logistical and economic prospects of destroying ABMC cemeteries was entirely unfeasible, and insulting to the dead. Representative Waite's proposal was mainly a rhetorical insult to France. Yet it publicly reminded the French of America's sacrifice for their nation on two different occasions.

In the weeks after Waite's proposal, French attacks on remains from World War I soldiers buried in its soil captured American headlines and put the ABMC on high alert. Days after the invasion of Iraq started, French vandals broke into the British World War I cemetery at Etaples outside of Paris where nearly 11,00o British, Canadian, Australian, and New Zealand soldiers rested. They spray painted the graves area with swastikas and insults like: "Dig up your trash, it's soiling our land," "Death to the Yankees," and "President Bush and Prime Minister Blair, Saddam will triumph and spill your blood.”27 This was not an attack on American military remains, but the vandalism contained clear anti-Americanism. President Bush was explicitly mentioned, and Great Britain was the United States' strongest ally in the Iraq invasion. The ABMC responded with "increased

24Ibid.

25 Representative Ginny Brown-Waite, “American Heroes Repatriation Act," H.R. 1265, $10^{8 \text { th }}$ Congress First Session, March 13, 2013, full text available at http://www.gpo.gov/fdsys/pkg/BILLS108hr1265ih/pdf/BILLS-108hr1265ih.pdf, accessed May 8, 2014.

${ }^{26}$ Friedman, Anti-Americanism, 5. See also "Remove War Dead From French Soil," The New York Times, September 16, 1966, Proquest Historical Newspapers.

${ }_{27}$ Jerry Seper, "Graveyard Graffiti Taunts the Allies," The Washington Times, April 4, 2003. 
vigilance over its 24 U.S. military cemeteries.”28 The ABMC's director of engineering and maintenance assured Americans that "We have on-site personnel 24 hours a day, we are concerned and we have increased our vigilance." ${ }^{29}$ Further adding, "this is not going to be tolerated, and we intend to work closely with local authorities and police to be sure [of it]." 30

President Chirac opposed the Iraq War, but his response to the desecration of graves revealed the sanctity the French felt towards the Allied dead that their soil held. Chirac described the graffiti as "inadmissible and shameful." ${ }^{11}$ He personally wrote Queen Elizabeth at Windsor Palace and stated, "From the French people and from me personally, I offer you my deepest regrets." ${ }^{2}$ He further noted that while he did not support the war his thoughts went out to the British soldiers currently engaged in combat.33 Other top French officials also spoke out. France's Minister of State Hamlaoui Mekachera, condemned the vandalism in the strongest terms and was appalled by the "violation of the memory of combatants who came to liberate our land." 34 Donnedieu de Vabres, the vice chairman of the French National Assembly's Foreign Affairs Committee, assured America and Great Britain that this "crime was committed in France, but in no way reflects the true feelings of France." 35 French resentment towards U.S. and British military aggression still showed itself at places of memory on the French landscape. In the days after the desecration at the British

\footnotetext{
${ }^{28}$ Ibid.

29 Ibid. Quoting ABMC director of engineering Thomas Sole.

${ }^{30}$ Ibid. Quoting ABMC director of engineering Thomas Sole.

${ }^{31}$ Ibid.

32 Ibid.

33 Ibid.

34 Ibid.

35Ibid.
} 
cemetery, "anti-American graffiti were sprayed on a memorial in the Luxembourg Gardens in Paris that commemorated the victims of the September 11 attacks in New York and Washington.”36

The public attention in France and the United States towards the memory of dead from past wars intensified through the first year of the Iraq War. 2004 was not only a presidential election year, but also marked the sixtieth anniversary of D-Day. President Bush capitalized on the opportunity and traveled to Europe during the anniversary to speak at the sites of American graves and urge the free world to take up arms. Bush's European visit included a three day trip through Europe, primarily visiting Italy and France where he could speak with "high-profile opponents of the war, including Pope John Paul II and President Chirac of France.” Police in both countries anticipated that Mr. Bush would face "large protests" and extra security measures went into place. 37 Protestors interviewed by international press made efforts to make the distinction that their hostility was not against "the sacrifices that the United States made sixty years ago, but against the Bush administration's occupation of Iraq."38 A communist protestor in Paris noted that "I am here today demonstrating against George Bush, but I will be on the beaches tomorrow celebrating and supporting America's involvement in liberation." 39 The protestors separated their attacks on present American policy from sacred memories and wished that President Bush do the same. Many "emphatically rejected Bush's repeated comparison of the acts of U.S. soldiers 6o years ago with the

\footnotetext{
${ }^{36}$ John Tagliabue, "Chirac Apologizes for Vandalized Graves," The New York Times, April 4, 2003, in Proquest Historical Newspapers.

37 Richard W. Stevenson, "Bush in Europe to Rally Support for Iraq Policy," The New York Times, June 4, 2004, in Proquest Historical Newspapers.

${ }^{38}$ Keith Richburg, “U.S.-French Divide Persists," The Washington Post, June 6, 2004, in Proquest Historical Newspapers.

39 Ibid. Quoting Helene Luc.
} 
military campaign in Iraq." 40 The ready-made response from French protestors commenting that American leaders used their memory of the World Wars to drum up international support for their current policies, indicated that this tactic was somewhat worn after nearly a century of use.

American reporters saw the strategic implications of Bush's European tour. New York Times reporter Richard Stevenson noted that "the trip provides Mr. Bush, as an incumbent seizing the spotlight on the world stage, a kind of visibility that [his opponent] Mr. Kerry cannot hope to match.” ${ }^{41}$ The biggest stage that Bush could stand upon that Kerry could not was "when Mr. Bush goes to the Normandy American Cemetery in Colleville-sur-Mer, France to talk as Commander-in-Chief about how the United States uses its military power in service of its ideals." ${ }^{2}$ The sixtieth anniversary ceremonies gave Presidents Bush and Chirac the opportunity to address the rocky relations between their two countries in the comfortable shadow of American military dead. Readers could assess the ceremony in differing ways, but close attention to the text leaves one with the feeling that President Chirac, more so than President Bush, used American memory to make a powerful contemporary statement. President Chirac did not disrespect the memory of American dead in France, however, his speech did effectively adopt a memory of American dead that painted a somewhat critical picture of the Iraq War. Chirac espoused the usual rhetoric of friendship that American military dead reminded nations of, and assured his audience that this friendship confidently "remains intact to this day." Even though lately the friendship was more of a

\footnotetext{
40 Ibid.

${ }^{41}$ Richard W. Stevenson, "Bush in Europe to Rally Support for Iraq Policy," The New York Times, June 4, 2004, in Proquest Historical Newspapers. $4^{2}$ Ibid.
} 
"demanding" partnership. Nevertheless, the partnership, like the corpses of Normandy, represented "eternal" friendship "founded in mutual respect." 43 Chirac never in his speech made open reference to Iraq, but he included French memories of the war that likely led the nation to not support the United States battle with the Iraqis. In World War II, France "experienced the long ordeal of war and occupation," something Chirac vocally believed Iraq surely would face also. France owed much to the United States for ending Nazi occupation, but the French also remembered "the terrible suffering during the course of the battle waged, the suffering of the soldiers, but also of the civilians. 44 This was not something that the French were willing to go through again, or inflict on others, unless the cause was deemed absolutely worthy. France looked to the memory of the World Wars as guideposts to future policy. To Chirac, the memories on their landscape spoke of "a duty of remaining faithful to our values ... to build a society which bears the hallmark of respect and dialogue, of tolerance and solidarity." 45 This "was the very quintessence" of D-Day. 46

President Bush's speech did not impart such strong feelings of Iraq. He did recall the successes of past alliances in Europe and reminded the audience that "our great alliance of freedom is strong, and still needed today." 47 Most of his speech, however, focused primarily on what drove his foreign policy-Christian faith. He mentioned prayer and divine guidance on numerous occasions. Bush clearly wanted his audience to leave the beaches of Normandy knowing that the American military was driven by

43 George W. Bush, “D-Day 60 ${ }^{\text {th }}$ Anniversary Remarks," June 6, 2004, from http://georgewbushwhitehouse.archives.gov/news/releases/2004/06/20040606.html, accessed May 8, 2014.

44 Ibid.

45 Ibid.

${ }^{46}$ Ibid.

47 Ibid. 
Christian morals. He concluded his remarks describing what the beaches of Normandy looked like after Americans won the day. They were covered with the debris of war, belts, canteens, socks, K-Rations, helmets, diaries, photos, and carnage. More importantly, "there were Bibles, many Bibles, mixed with the wreckage of war. Our boys had carried in their pockets the book that brought into the world this message: Greater love as no man than this, that a man lay down his life for his friends." 48 This willingness to sacrifice for friends impelled the United States to come to France's aid twice, and might possibly bring France to support America's future endeavors.

President Bush apparently found that using the memory of American sacrifice in the World Wars a worthy way to engage with the French in this turbulent period. The following year, the Washington Post reported that the "administration is highlighting the thousands of overseas graves of American war dead as part of a public relations campaign to convince foreigners of the United States' good intentions in its battles with Islamist terrorists." 49 The face of this public relations campaign was the small and unassuming American Battle Monuments Commission. Brigadier General John Nicholson was appointed to head the ABMC by President Bush. General Nicholson worked with the Bush administration to "aggressively recruit more foreign and American visitors" to U.S. military cemeteries overseas. 50 As America waged a War on Terror, Nicholson saw the ABMC as a tool to improve international perceptions of the United States. He wanted "them [Europeans] to hear stories of how American men and women died for democracy." ${ }^{1}$ "Thousands of graves are a reminder that the U.S. came

\footnotetext{
48 Ibid.

49 Rowan Scarborough, "Military Cemeteries Abroad Show U.S. Good Will, The Washington Times, October 24, 2005, in Proquest Historical Newspapers. Quoting ABMC Secretary General John Nicholson. 50 Ibid.

${ }^{51}$ Ibid. Quoting ABMC Secretary General John Nicholson.
} 
when asked, restored democracy and then left without seizing territory, colonies, slaves, reparations or money." ${ }^{2} \mathrm{ABMC}$ sites were not just commemorative locations, but cultural weapons that provided visitors an inspirational and educational destination.53 Chairman Nicholson's vision of what ABMC sites might achieve was not new, he just stated the goal in a more direct way than others before him. The goal of boosting public relations through war dead was not new to President Bush, nor would it end with President Bush.

\section{Dishonorable Barricades}

From October 1-16, 2013, the United States federal government closed down when bipartisan differences in Congress postponed the passage of the federal budget. Coming in the era of sensationalized, twenty-four hour news coverage, the shutdown dominated headlines for its duration. A special timer ran on many news channels to inform the world of each second of the closure. Republicans and Democrats blamed one another, President Barack Obama's leadership abilities faced serious questioning, some 800,0oo federal employees went on unpaid furlough, and countless Americans realized how big of a presence their federal government was in their life when denied access to services often taken for granted. Some of the most public outrage stemmed from blocked access to national parks, memorials, and cemeteries. Many Americans felt they had a right to visit these natural treasures no matter what the political circumstance.

When the Washington Post reported the first day of the government shutdown, one of the agencies it chose to highlight was the small, and relatively unknown American

52 Ibid. Quoting ABMC Secretary General John Nicholson.

53 Ibid. Quoting ABMC Secretary General John Nicholson. 
Battle Monuments Commission. A profile of this Commission's final hours before closure was an intelligent choice. It explained the ABMC's commemorative work abroad and showed that the shutdown had international reach.54 It also informed the American public that sites like American military cemeteries had no immunity from the budget freeze. The iconic opening scene from Saving Private Ryan would not be replayed in real life by aged veterans making sacred pilgrimages to visit deceased comrades abroad for the foreseeable future. The Normandy American Cemetery was closed for business. 55 It was with a heavy heart that, Michael Conley, the Chief-of-Staff of the ABMC's Arlington office informed his staff that they had only four hours to "tie up all loose ends" and go home. $5^{6}$ Only he, and the superintendents of the overseas cemeteries would continue working as essential ABMC employees. In the final four hours, the ABMC's digital communications manager unpublished the ABMC's Facebook page, de-activated its YouTube account, and closed the website (including access to burial databases). 57

Americans who followed the ABMC's social media presence knew the possibility of such closures. The ABMC posted a warning the previous day on Facebook that "all cemeteries and memorials would be closed for the duration of the shutdown." 58 Timothy Nosal, the ABMC's public affairs director told the Post reporter that his primary worry with the shutdown was for "all the visitors to the foreign cemeteries-people who had spent years saving up for trips to visit the gravestones of loved ones and who would now

\footnotetext{
54 Monica Hesse and Lisa Rein, “An 'orderly shutdown': Set your out-of-office email, and don’t forget to water the Plants," The Washington Post, October 1, 2013, online edition, http://www.washingtonpost.com/lifestyle/style/an-orderly-shutdown-set-your-out-of-office-e-mail-anddont-forget-to-water-the-plants/2013/10/01/d67ce41a-2aad-11e3-8ade-a1f23cda135e story.html, accessed October 15, 2014.

55 Ibid.

${ }^{5}$ Ibid.

57 Ibid.

${ }^{8}$ ABMC Facebook post on September 30, 2013, at https://www.facebook.com/abmcpage/timeline, accessed October 15, 2013.
} 
arrive to find those cemeteries closed." 59 Nosal's concern was on point. In the comments to the Facebook message announcing the closure one woman posted her shock. She and her 81 year old father had saved "thousands of dollars to travel to a foreign country for one visit" to his uncle's grave. ${ }^{60}$ They were scheduled to travel to the grave the first day of the shutdown and were in no position to "just zip back" at a later date. ${ }^{61}$ Other commenters sided with the upset visitor, some with more anger than others. One man posted that he would "demo" the gate for her if he was present and then place a blank check in the ABMC's office to pay for the damage. ${ }^{62}$ Others displayed reserved anger ranging from disappointment that the "dead were disrespected by our politicians" to feelings of sadness because "brave heroes deserve better than this." 63 Commenters showed a general consensus that such closures represented a distasteful political game. The American soldiers buried in France did not sacrifice for this kind of politics. ${ }^{64}$ A sense of national embarrassment also came through in the posts. One individual feared what European visitors to American sites would think then they arrived to cemeteries only to see a chained gate accompanied by a sign that read "closed for lack of funding." 65

\footnotetext{
59 Monica Hesse and Lisa Rein, "An 'orderly shutdown."

${ }^{60}$ Georgann Faulkner Schuch, last modified September 30 at 4:44pm, accessed October 15, 2013, https://www.facebook.com/abmcpage. 
The French did indeed follow news of the shutdown and status of American military cemeteries on their soil. The newspaper Liberation reported that the Suresnes American Cemetery had been hampered by the shutdown. French reporters interviewed the ABMC's superintendent at Suresnes Angelo Munsel. Munsel reported that he had to send home all of his French workers, but kept them on alert in the event that damages happened to the cemetery. Munsel was the only employee allowed onsite during the shutdown, and he could receive no visitors. He reported that it was "sad, but not the end of the world," and hoped for a timely resolution. ${ }^{66}$ Munsel wished to impart to the French audience an understanding that he was not a politician, but had to follow their orders. ${ }^{67}$ The Liberation reporter noted that all other French ABMC sites also closed down, but that Normandy American Cemetery was a special case because visitors could access the cemetery grounds by entering from the staircase directly from the beach instead of the gates. Still, the ABMC would ask all visitors to leave the ground without any confrontation. ${ }^{68}$ It seemed strange to the reporter that a cemetery was the target of closure while U.S. consular services operated normally. 69

French readers of the article validated American fears that such closures would embarrass the United States. One French commenter saw the closure of cemeteries as evidence of "capitalism's permanent failure," while another saw it as a signifier of “Europe's return to leadership” and America's imminent decent into economic depression at any moment. ${ }^{\circ}$ French business owners near more visited cemetery sites

\footnotetext{
${ }^{66}$ Dominique Albertini, “Suresnes American Cemetery Leaded by the 'Shutdown,” Liberation, online edition, October 1, 2013, HTTP://WWW.LIBERATION.FR/ECONOMIE/2013/10/O1/A-SURESNES-LECIMETIERE-AMERICAIN-PLOMBE-PAR-LE-SHUTDOWN_936120, accessed October 15, 2013.

67 Ibid.

68 Ibid.

69 Ibid.

70 Ibid.
} 
worried that that closures would hurt them financially. An anonymous restaurateur in Normandy noted that on the first day of the shutdown she had "80-90 customers" but only because they arrived not knowing the cemetery was closed..$^{71}$ The cemetery drew in more than one-million visitors each year and kept her business alive. If the U.S. government kept the cemetery closed for a lengthy period, local businesses faced financial deprivation. French tour guides also felt the sting of the shutdown. French tour guide, Michel Mickael typically filled his Peugeot van with a dozen tourists and escorted them around Normandy. On the first day of the shutdown, he had only one. Another French driver met a group of French tourists at the Normandy train station during the shutdown and bluntly warned them that 'the [American] memorial is closed. The Americans are out of money!"72 While French financial concerns do not represent a deep sentimental attachment to American cemeteries, they do indicate the touristic draw that American military cemeteries had in France. This type of magnetism was what the ABMC hoped all of its cemeteries would possess in the planning stages.

\footnotetext{
71 "Shutdown Closes U.S. Military Cemeteries in Europe," Fox News, October 1, 2013, available at http://www.foxnews.com/world/2013/10/01/shutdown-closes-us-military-cemeteries-in-europe/, accessed October 15, 2013.

${ }^{72}$ Stacy Meichtry, "Shutdown Hits Normandy," The Wall Street Journal, October 13, 2013, in Proquest Historical Newspapers.
} 


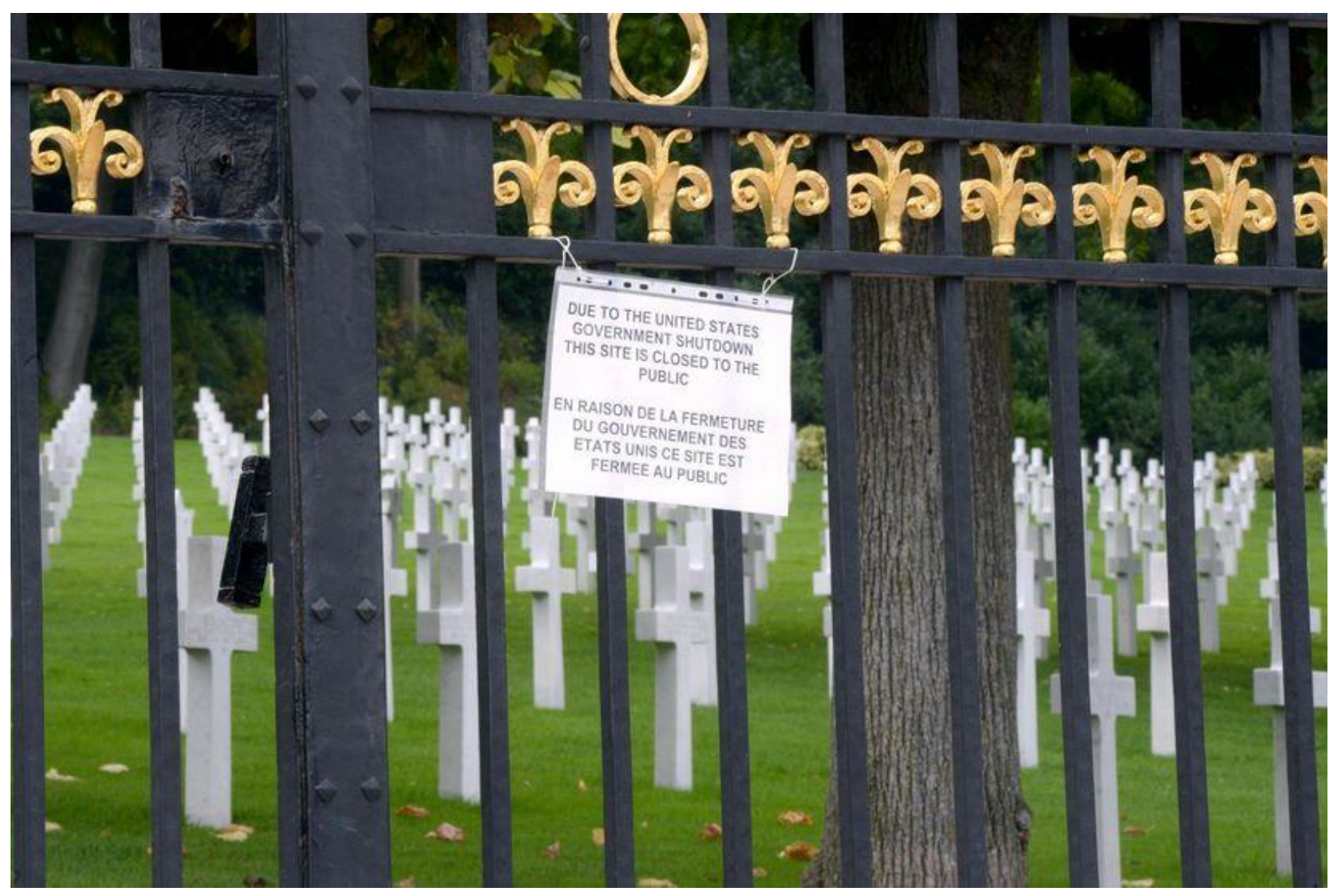

Conclusion.1 : Notice to visitors of Suresnes American Cemetery posted October 1, 2013. Source: Photo Pierre Andrieu. AFP.

Public outrage over the closure of national memorials and cemeteries swelled in the days following initial reports of ABMC closures. More stories of American tourists denied access to the grounds of military cemeteries abroad appeared in national and local newspapers. The Winston Salem Journal provided a story four-days after the shutdown of a North Carolina couple who saved money to fulfill a "long-held dream of honoring local heroes by placing a red rose on each grave."73 Instead, the couple arrived to a closed gate and futilely waited for access while busloads of "outraged" Americans

\footnotetext{
73 Wesley Young, "Local Couple Turned Away from D-Day Memorial France," The Winston-Salem Journal, October 5, 2013, available at http://www.journalnow.com/news/local/article 047a6c30-2d5f11e3-9a7f-001a4bcf6878.html, accessed on October 15, 2013.
} 
pulled up on their "once-in-a-lifetime trip." 74 The turned-away Americans piled up their roses at the locked gates in honor of the dead instead of placing them over the intended graves. The North Carolina couple wanted their local paper to know that they traveled to Europe to honor Americans who died for freedom, but instead found that the sacred remains of "heroic fathers and grandfathers" used by their government as disrespectful "political ploy."75 Other tourists at Normandy did not follow the rules as the North Carolina couple did. A 71 year old veteran from Ventura, California arrived at Normandy "embarrassed to see that the American flag was not flying over his comrades' graves." $76 \mathrm{He}$ and his wife ignored the signs to stay off the cemetery grounds and joined other American tourists in scaling the cemetery walls to respect the graves without government guidance.77 Although thousands of miles away from Washington, American remains entered the domestic political game.

The chapters coming before this have shown how the politicization of places of memory is not new to American culture. The American government systematically used the memory of military remains abroad for political and diplomatic purposes throughout the twentieth century. Yet, for the most part, protestation from the public remained nonexistent. These American places of memory on European soil largely existed in relative stability through the through the twentieth century. They received constant care, repetitious ceremony, and seemingly became commonplace. A critic of these sites, or person skeptical of their cultural importance, might argue that the routineness of their existence signified diminishing significance in American culture.

\footnotetext{
74Ibid.

75 Ibid.

${ }^{76}$ Stacy Meichtry, "Shutdown Hits Normandy,” The Wall Street Journal, October 13, 2013, Proquest Historical Newspapers. 77 Ibid.
} 
With the American World War I generation gone and the WWII generation rapidly fading, why would America care about their places of memory? The 2013 public outcry against closing national places of memory to make political statements revealed that these sites still retained importance to American cultural values. There is little public backlash when the places of memory are used by politicians in a way that sustains a positive image of the United States. Military remains abroad represent the best aspects of the United States, they are American citizens who traveled abroad and sacrificed themselves for ideas bigger than the United States. When leaders make pilgrimages to these sites and make statements that coincide with this mission there is little need for an attack. And, when the public has open access to these sites to personally experience their places of memory, a call-to-arms to preserve the sites is unnecessary. When the status-quo is challenged, protest arises.

Closure of cemeteries abroad received national attention, but most of the public battle against government closures of sacred sites took place in Washington. The American public blamed President Obama and Democratic leadership for the 2013 government shutdown, and the Tea Party faction of the Republican Party. Many Americans viewed the closing of ABMC cemeteries abroad as a disgraceful political tactic, but these locations did not serve as suitable locations to protest the closures. They were not American soil, nor were they easily accessible. A remedy to the problem was for protestors to target places of memory in Washington that commemorated the same sacrifice as ABMC sites abroad. The war memorials on the National Mall are some of the most visited sites in Washington, DC. On any given day tourists crowd the Vietnam Memorial, Korean War Memorial, and the newer World War II Memorial. During the 2013 shut down these sites, along with all others on Mall, were barricaded 
and public access denied. Just as Americans who had already planned visits to ABMC cemeteries abroad still made their trips, so too did Americans who made travel plans to the National Mall. Thousands of Americans with no plans to travel to the Mall scheduled visits during the shutdown as a means to protest.

Throughout the shutdown, American World War II veterans arrived daily to visit the memorial to their sacrifice that did not come until 2004, fifty-nine years after the war concluded. It should come as no surprise that a public relations fiasco took place when eighty and ninety year old WWII veterans arrived to their memorial on the National Mall to find barricades and guards denying them access. For many of them, this was their one chance to visit the memorial before their death. Each day various news agency reported the political attack waged against the "venerable club" of World War II veterans..$^{8}$ Images of elderly WWII veterans "storming the barricades" to their memorial just as they had stormed the battlefields of World War II came to symbolize the unpopularity of the shutdown.79 The elderly veterans represented not only liberators of Europe and the Pacific, but modern day "monument liberators of Washington."80

Despite their partial responsibility for the closure of National places of memory, representatives of the Tea Party turned to closed war memorials in Washington to make political statements. Two weeks into the government closure, Tea Party leaders Senator Ted Cruz and former Governor Sarah Palin spoke at the World War II Memorial as part

\footnotetext{
78 Kathleen Parker, "Closing Memorials was a Monumental Mistake, " The Kansas City Star, October 6, 2013, available at http://www.kansascity.com/2013/10/06/4529997/closing-memorials-was-amonumental.html, accessed October 15, 2013.

79 Ibid.

8o Ibid.
} 
of the Million Vets March.81 Although National Parks police had sporadically allowed World War II veterans to pass through the barricades to memorials, full public access still was not allowed. The Million Vets March was an effort to push the government to grant full access to these sites. Thousands of protestors turned up at the monuments and "angry exchanges between police and demonstrators took place." 82 It was not necessary for police to make mass arrests of the protestors, but physical altercations between police and demonstrators did take place. 83 Senator Cruz and Governor Palin spoke to crowd in the early stage of the protest at the World War II Memorial. Their remarks primarily centered on President Obama's disrespect for U.S. armed forces. Senator Cruz demanded to know why President Obama was spending federal money to barricade the monuments. ${ }^{84}$ Governor Palin mockingly called the barricades "barrycades," after President Obama's nickname of Barry. She also let the audience know that she was there to "honor our vets" and to point out that blocking memorials was no way for a "commander-in-chief to show respect and gratitude to our military." 85 After listening to Republican leaders, many of the protestors physically removed the barricades and carried them to the wall of the White House. ${ }^{86}$

${ }^{81}$ Bill Chappell, "Barrier Breached at World War II Memorial on Mall," National Public Radio, October 13, 2013, available at http://www.npr.org/blogs/thetwo-way/2013/10/13/233334336/barriers-breachedat-world-war-ii-memorial-on-mall, accessed October 15, 2013.

82 Meredith Somers and Andrea Noble, "Hundreds of Protestors Storm WWII Memorial, Lafayette Square," The Washington Times, October 13, 2013, available at http://www.washingtontimes.com/news/2013/oct/13/hundreds-protesters-storm-wwii-memoriallafayette-/?page=all, accessed October 15, 2013.

83 Ibid.

84 Katrina Trinko, "Palin, Cruz, Lee Talk to Protestors at WII Memorial," The National Review Online, October 13, 2013, available at http://www.nationalreview.com/corner/361106/palin-cruz-lee-talkprotesters-ww-ii-memorial-who-moved-barricades-white-house-katrina, accessed October 15, 2013. 85 Ibid.

86 Meredith Somers and Andrea Noble, "Hundreds of Protestors Storm WWII Memorial, Lafayette Square." 
The final battlefield of the government shutdown that needs included in this conclusion is the treatment of military dead killed in ongoing Middle Eastern wars during the shutdown. The protest against government policies regarding federal disbursement of funds to care for war dead meshed with perceptions of disrespect for the memory of past veterans. Public reaction to each demonstrated how American memory of the World Wars still retained relevance to contemporary Americans. It also bridged the gap between sacrifice in the War on Terror to the World Wars.

On October 8, a week into the shutdown, senior Senators John McCain (RArizona), and Harry Reid (D- Nevada) called a live quorum in the Senate that forced the entire Senate to gather and hear speeches. The purpose of this gathering was to denounce an unexpected result of the shutdown-the suspension of the $\$ 100,000$ death gratuity wired to families of American military personnel killed in service to assist them with funeral expenses and travel to receive their bodies. ${ }^{87}$ The action from Senate leaders came in response to the deaths of five American service members killed by an improvised explosive device in Afghanistan in the previous days. Senator McCain berated his fellow Congressmen and expressed embarrassment, outrage, and shame that political bickering had blocked deserved "benefits for those who served and sacrificed" for their country. ${ }^{88}$ Congress seemed shocked when veterans' organizations and family members notified them of the inexcusable delay in funds for bereaved families. Legislation was passed to fund the military during the shutdown, without understanding that death gratuity payments were not a part of the plan. ${ }^{89}$ Throughout the first week of

\footnotetext{
87 Bryan McClam, "Senate Elders Denounce Suspension of Death Benefit for Families of Fallen," NBC News, October 8, 2013, available at http://www.nbcnews.com/news/other/senate-elders-denouncesuspension-death-benefit-families-fallen-f8C11359108, accessed on October 15, 2013. 88 Ibid.

89 Ibid.
} 
the shutdown, seventeen American service members died in the line of service and none of their families received money to care for their remains until Congress acted on October 8.90 The New York Daily News ran a full length article profiling the service members killed in Afghanistan and included interviews from their families. In conclusion it was pointed out that "astoundingly, while the payments to families are delayed and the rest of American is making do without federal services, the gyms on Capitol Hill remain open, and, of course, members of Congress, unlike furloughed employees, are still collecting pay."91

The very open coverage of Congressional failure to care for American military dead during wartime coincided with protest over the closure of sacred American sites of memory at home and abroad. Countless other stories ran about other casualties of the government shutdown, but anyone who lived through the eighteen days of the shutdown and kept up with media coverage will likely remember the prominent place that care for American military dead, past and present, held in the public discourse. As a whole, it seemed that Americans did not expect the memory of veterans or care of military remains to become targets in a political battle.

It is still too early to determine how the War on Terror will be commemorated in the United States. The combined wars in Iraq and Afghanistan represent the longest sustained war that the United States has ever fought. Although an exit is in sight as this work is written, American military personnel still are dying in Middle Eastern theaters. If the discourse of the 2013 government shutdown offers any indication of how the more

\footnotetext{
90 Ibid.

${ }^{91}$ Joseph Straw and Stephen Rex Brown, "Shutdown Leaves Kin of Dead Soldiers Without Money for Funerals," New York Daily News, October 9, 2013, available at http://www.nydailynews.com/news/politics/shutdown-leaves-kin-dead-soldiers-burial-funds-article$\underline{1.1480080}$, accessed on October 15, 2013.
} 
recent wars will be commemorated, it appears that the memory of American military sacrifice in the World Wars will be linked together with the War on Terror.

The sacrifices of American soldiers in the World Wars continues to show its pliability. American military sacrifices have evolved into one rhetorical mass with unclear divisions. The enemies of the United States throughout the twentieth century into the twenty-first have blurred into one. Clear distinctions between militarism, authoritarianism, communism, and radical Islamism are almost nonexistent. As the World War II generation disappears, their memory becomes more open to reinterpretation and expansion. The elderly WWII veterans that took part in protest during the shutdown were joined by their offspring and veterans from other twentieth and twenty-first century wars. They all rallied around a belief that American military sacrifice should never be compromised to achieve political goals. Culturally, military memory in the United States is something to be employed to advance national greatness, not impair it. As long as American military dead impart favorable memories of American sacrifice to allied partners, the United States maintains a strong chance of continuing as a hegemonic force culturally and militarily. When host countries no longer see value in the sacrifice of American military dead abroad, or fail to see connections of past American sacrifice to contemporary battles, the United States will have slipped from its position of power in international relations.

Americans care about the preserving the memory abroad that the 120,000 remains from World War I and World War II represent. The ABMC is not the most the most well known government agency, but its mission is deemed important when challenged. Do the political uses of these remains detailed in this conclusion leave us with any observations about new trends in this American memory abroad? While 
Suresnes was the ABMC crown jewel following the Great War and in the early years of the Cold War, it seems to have lost some of its draw. An online travel blog from an American couple that visited Suresnes not long before this was written indicates waning American interest in this site. The couple wrote of their conversation with Suresnes's American superintendent Angelo Munsel. Munsel reportedly told them before departing that "very few people ever come here, thanks for stopping by."92 The author's own experience at Suresnes can verify this observation. In a visit to Suresnes in the summer of 2012, during the peak of the Paris tourist season, no other tourists arrived at the Suresnes American cemetery during a several hour visit. Superintendent Munsel provided a similar assessment of lagging visitation. What explains the lapse in Americans going to Suresnes? As the contemporary presidential speeches show, the Normandy American Cemetery, not Suresnes is now the premier location to make commemorative speeches and engage in memory diplomacy.

American sacrifices on D-Day capture the American imagination. Normandy has become a destination spot for many American tourists. A visit to Normandy allows Americans to walk the D-Day beaches and other Normandy battlefields made popular by films like Saving Private Ryan, Band of Brothers, and The Longest Day. The American cemetery at Normandy overlooks the landing beaches, provides a beautiful vista, and contains a state-of-the-art museum that provides historic context of the D-Day invasion. Suresnes offers a breathtaking vista of Paris, but fails to compete with other tourist offerings of the city. It is also somewhat difficult to travel to Suresnes. Public transit to the suburb is available, but not easy for a foreigner with no grasp of the French

92 "Pitts in Paris," April 3, 2014, available at http://tyntyn50.wordpress.com/2014/04/04/day-48-april-3the-road-to-calvary/, accessed May 12, 2014. 
language. Suresnes is still the location of commemorations and speeches, but Normandy is now the crown jewel of ABMC cemeteries. While Suresnes is a cemetery of both World War I and World War II, the twenty-four WWII unknowns do not make it as much a relic of WWII as the 9,000 remains of Normandy.

It is likely that visitation to Suresnes and other ABMC WWI cemeteries will increase in the near future. The year 2014 marks the centennial of the Great War in Europe, and 2017-2018 mark the centennial of America's entrance. It is unknown what type of resurgence the Great War will have in the American collective memory. The ABMC is anticipating increased focus on its WWI sites. They have recently undertaken programs to locate important sites on American World War I battlefields and create an interpretative center at the Meuse-Argonne American cemetery. It is unlikely that visitation levels will match the levels of the interwar years. Official pilgrimages are long over and, for the most part, mourners of the Great War no longer exist. The American World War I remains, perhaps more so than WWII remains, are becoming relics that tell a vanishing story, more so than painful lived memories. It will be interesting to study the visitation trends in ABMC cemeteries midcentury. The draw of D-Day shows no signs of declining, but public imagination for other World War I or World War II battles might spike interest in other ABMC cemeteries. The cemeteries are not going anywhere, and the United States government will surely keep its promise to perpetually care for these shrines unless something catastrophic happens. These sites will also continue to be useful places for leaders to engage in memory diplomacy-so long as the public finds the locations meaningful places of memory. 


\section{Selected Bibliography}

\section{Manuscript and Archival Sources}

Library of Congress, Washington, D.C.

Newton D. Baker Papers

Charles Bohlen Papers

Gold Star Mothers Collection

John Pershing Papers

U.S. Army Military History Institute, Carlisle, PA

William O. Davis, Sr. Papers

Hardy Derx Papers

James Gavin Papers

William Jones Papers

Thomas North Papers

Matthew Ridgway Papers

World War I Soldier Surveys

National Archives I, Washington, D.C.

RG 66: Commission of Fine Arts

RG 92: Records of the Quartermaster General

National Archives II, College Park, MD

RG 59: Records of the Department of State

RG: 84: Post Files of the Department of State

RG 92: Records of the Quartermaster General

RG 117: Records of the American Battle Monuments Commission

RG 218: Records of the Joint Chiefs of Staff

RG 330: Records of the Office of the Secretary of Defense

RG 407: Records of the Adjutant General

John F. Kennedy Presidential Library, Boston, MA

JFK Papers, National Security Files

JFK Papers, President's Office Files

JFK Papers, White House Central Subject File, ABMC

Sargent Shriver Papers

Richard Nixon Presidential Library, Yorba Linda, CA

Richard Nixon Papers, White House Subject Files, FG 73 ABMC

George C. Marshall Foundation, Lexington, VA

George C. Marshall Papers 
Woodrow Wilson Presidential Library, Staunton, VA

Larry T. Grayson Papers

American Battle Monuments Commission, Arlington, VA

Photographic Collections

American Battle Monuments Commission Cemetery Files

Meuse-Argonne American Cemetery, Romange-sous-Montaucon, France

St. Mihiel American Cemetery, Thiaucourt, France

Suresnes American Cemetery, Suresnes, France

American Battle Monuments Commission Overseas Operations Office, Garches, France Dedication Files

National World War I Museum, Kansas City, MO

Gold Star Mothers Collection

National Personnel and Records Center, St. Louis, MO

World War I \& World War II Burial Files

Stars and Stripes Library \& Archives, Washington, D.C.

Photographic Files

West Virginia University Regional Collections, Morgantown, WV

Photographic Files

\section{Newspapers}

New York Times (United States)

New York Daily News (United States)

Washington Post (United States)

Chicago Tribune (United States)

Boston Daily Globe (United States)

Baltimore Sun (United States)

Los Angeles Times (United States)

Kansas City Star (United States)

The National Review (United States)

Wall Street Journal (United States)

Winston-Salem Journal (United States)

Christian Science Monitor (United States)

NBC News (United States)

CNN News (United States) 
Fox News (United States)

National Public Radio News (United States)

Le Gaulois (France)

L'Ouest-Éclair (France)

L'Humanité (France)

Le Figaro (France)

Le Monde (France)

Liberation (France)

Guardian (United Kingdom)

The Times (United Kingdom)

Associated Press

\section{Printed Primary Sources}

American Battle Monuments Commission. American Armies and Battlefields in Europe: A History Guide and Reference Book. United States Government Printing Office: Washington D.C., 1938. Reprinted by The United States Army Center of Military History: Washington, D.C., 1992.

American Battle Monuments Commission. A Guide to the American Battle Fields in Europe. Washington: U.S. G.P.O., 1927.

American Battle Monuments Commission: Hearings Before the Committee on Foreign Affairs, House of Representatives, Sixty-Seventh Congress, Second and Third Sessions on H.R. 9634 and H.R. 10801, March 15-2O, November 28, December 7-9, 1922. Washington, D.C.: GPO, 1922.

American Battle Monuments Commission: Hearings Before the Committee of Foreign Affairs, House of Representatives, Seventy-Ninth Congress, First Session on H.R. 6393, May 15, 1946. Washington, D.C.: GPO, 1946.

American Dead in World War II: Agreement Between the United States of America and France, Implementing and Completing Agreement of October 1, 1947. Washington, D.C.: Department of State.

Bohlen, Charles E. Witness to History, 1929-1969. New York: W.W. Norton \& Co, 1973.

Bullitt, Orville ed. Correspondence Between Franking D. Roosevelt and William C. Bullitt: For the President, Personal and Secret. Boston: Houghton Mifflin Company, 1972.

Duhamel, Georges, and Charles Miner Thompson. America the Menace. Allen \& Unwin, 1931. 
Eichhorn, David Max, Greg Palmer, and Mark S. Zaid. The GI's Rabbi: World War II Letters of David Max Eichhorn. Lawrence, Kan: University Press of Kansas, 2004.

Graves Registration Service. Location of Graves and Disposition of Bodies of American Soldiers who Died Overseas. Washington, D.C.: Government Printing Office, 1920.

Griffin, Roger. Fascism. Oxford: Oxford University Press, 1995.

Hayes, Ralph. Care of the Fallen: A Report to the Secretary of War on American Military Dead Overseas. Washington, D.C.: Government Printing Office, 1920.

Hearing Before A Subcommittee of the Committee on Military Affairs United States Senate, Seventieth Congress, First Session, on H.R. 5494, Bill to Enable the Mothers and Unmarried Widows of the Deceased Soldiers, Sailors, and Marines of the American Forces Interred in the Cemeteries of Europe to Make a Pilgrimage to these Cemeteries, May 14 1928, Part I \& II. Washington, DC: Government Printing Office, 1928.

History of the American Graves Registration Services, Q.M.C. in Europe. Washington, D.C.: Office of the Quartermaster General, 1920.

Investigations of the National War Effort: House Report of the Committee on Military Affairs, Seventy-Ninth Congress, Second Session, House Resolution 20, A Resolution Authorizing the Committee on Military Affairs to Study the Progress of the National War Effort, June 1946. Washington, D..C: Government Printing Office, 1946.

Marcosson, Isaac. "The Americanization of Belleau-Wood.” The Saturday Evening Post, November 14, 1925.

Marshall, George C., Forrest C. Pogue, and Larry I. Bland. George C. Marshall: Interviews and Reminiscences for Forrest C. Pogue. Lexington, Va: G.C. Marshall Research Foundation, 1991.

Marshall, George C. "Our War Memorials Abroad: A Faith Kept." The National Geographic Magazine. The National Geographic Society, CXI, No. 6, June 1957.

Mott, T. Bentley. Myron T. Herrick: Friend of France, An Autobiographical Biography. Garden City, New York: Doubleday and Dorran, 1929.

Nichols, David ed. Ernie's War: The Best of Ernie Pyle's World War II Dispatches. New York, New York: Random House, 1986.

Pershing, John J. "Our National War Memorials in Europe." The National Geographic. The National Geographic Society, LXV, No. 1, January 1934. 
Psychology for the Fighting Man: Prepared for the Fighting Man Himself by a Committee of the National Research Council. Washington, DC: The Infantry Journal, 1943.

Report and Recommendations Covering Graves Registration Service in the European Theater of Operations. European Theater: Office of the Chief of Military History, Study No. 107, 1945.

Romier, Lucien, and Matthew Josephson. Who Will Be Master, Europe or America? New York: Macaulay Co, 1928.

Shomon, Joseph James. Crosses in the Wind. New York, N.Y.: Stratford House, Incorporated, 1947.

Twenty Sixth Annual Report of the American Scenic and Historic Preservation Society, 1921, To the Legislature of New York. Albany, New York: J.B. Lyon Company, 1922.

White, William R. “Our Soldier Dead.” The Quartermaster Review, Vol. IX, No. 6. May 1930.

Articles \& Essays

Bruggemann, Karsten and Adres Kasekamp. "The Politics of History and the War of Monuments in Estonia." Nationalities Papers 36, No. 3 [2008], 425-448.

Budreau, Lisa. "The Politics of Remembrance: The Gold Star Mothers' Pilgrimage and America's Fading Memory of the Great War.” The Journal of Military History, vol. 72, no. 2, April 2008. Bruce Vandervot, ed. Published Quarterly for the Society for Military History by the George C. Marshall Foundation and Virginia Military Institute.

Coleman, Bradley Lynn. "Recovering the Korean War Dead, 1950-1958: Graves Registration, Forensic Anthropology, and Wartime Memorialization." The Journal of Military History, vol. 72, January 2008.

Gienow-Hecht, Jessica. "Cultural Transfer.” From, Michael Hogan and Thomas Paerson, Explaining the History of American Foreign Relations. New York: Cambridge University Press, 2004.

Golsan, Richard. "From French Anti-Americanism and Americanization to the 'American Enemy." In The Americanization of Europe: Culture, Diplomacy, and Anti-Americanism After 1945, edited by Alexander Stephan. New York: Berhahn Books, 2006. 
Grossman, Elizabeth G. "Architecture for a Public Client: The Monuments and Chapels of the American Battle Monuments Commission." Journal of the Society of Architecture Historians, Vol. XLIII, No. 2, May 1984.

Gulliford, Andrew. "Bones of Contention: The Repatriation of Native American Human Remains. The Public Historian. Vol. 18, No. 4, Fall 1996.

Kitson, Simon. "Creating a Nation of Resistors'? Improving French Self-Image, 194446." In The Lasting War: Society and Identity in Britain, France and Germany After 1945. Edited by Monica Riera andGavin Schaffer, 67-85. New York: Palgrave MacMillan, 2008.

Laqueur, Thomas. "Memory and Naming in the Great War." In Commemorations: The Politics of National Identity, edited by John R. Gillis, 150-167. Princeton: Princeton University Press, 1994.

Rose, Arnold M. "Anti-Americanism in France." The Antioch Review, Vol. 12, No. 4, Winter, 1952.

Sherman, Daniel. "Art, Commerce, and the Production of Memory in France after WWI." In Commemorations: The Politics of National Identity, edited by John R. Gillis, 186-211. Princeton: Princeton University Press, 1994.

Stone, Dan. "Memory War in the New Europe." In The Oxford Handbook of Modern European History. Edited by Dan Stone, 714-731. Oxford: Oxford University Press, 2012.

"Where are the Bodies? The Public Historian. Vol. 32, No. 1, February 2010.

\section{Books}

Adams, Michael C. C. The Best War Ever: America and World War II. Baltimore: Johns Hopkins University Press, 1994.

Appy, Christian G. Working-Class War: American Combat Soldiers and Vietnam. Chapel Hill: University of North Carolina Press, 1993.

Arndt, Richard. The First Resort of Kings: American Cultural Diplomacy in the Early Twentieth Century. Washington, DC: Potomac Books, 2005.

Balkoski, Joseph. Beyond the Beachhead The 29th Infantry Division in Normandy. Mechanicsburg, PA: Stackpole Books, 1999. 
Barkan, Elazar. The Guilt of Nations: Restitution and Negotiating Historical Injustices. New York: Norton, 2000.

Blight, David W. Race and Reunion: The Civil War in American Memory. Cambridge, Mass: Belknap Press of Harvard University Press, 2001.

Blower, Brooke Lindy. Becoming Americans in Paris Transatlantic Politics and Culture between the World Wars. Oxford: Oxford University Press, 2011.

Bodnar, John E. Remaking America: Public Memory, Commemoration, and Patriotism in the Twentieth Century. Princeton, N.J.: Princeton University Press, 1991.

Bruggerman, Seth C. Born in the U.S.A.: Birth, Commemoration, and American Public Memory. Amherst: University of Massachusetts Press, 2012.

Brundage, W. Fitzhugh. Where These Memories Grow: History, Memory, and Southern Identity. Chapel Hill: University of North Carolina Press, 2000.

Budreau, Lisa. Bodies of War: World War I and the Politics of Commemoration in America, 1919-1933. New York: New York University Press, 2010.

Chandler, Alfred D. The Visible Hand: The Managerial Revolution in American Business. Cambridge, Mass: Belknap Press, 1977.

Connelly, Mark. The Great War, Memory and Ritual: Commemoration in the City and East London, 1916-1939. Woodbridge, Suffolk: Royal Historical Society/Boydell Press, 2002.

Cook, Robert. Troubled Commemoration The American Civil War Centennial, 19611965. Baton Rouge: Louisiana State University Press, 2007.

Cooper, John Milton. Woodrow Wilson: A Biography. New York: Alfred A. Knopf, 2009.

Costigliola, Frank. Awkward Dominion: American Political, Economic, and Cultural Relations with Europe, 1919-1933. Ithaca: Cornell University Press, 1984.

France and the United States: The Cold Alliance Since World War II. New York: Twayne Publishers, 1992.

Davenport, Lisa E. Jazz Diplomacy Promoting America in the Cold War Era. Jackson: University Press of Mississippi, 2009.

De Grazia, Victoria. Irresistible Empire : America's Advance Through TwentiethCentury Europe. Cambridge, Mass.; London: Belknap Press of Harvard Univ. Press, 2006. 
Dean, Robert D. Imperial Brotherhood: Gender and the Making of Cold War Foreign Policy. Amherst: University of Massachusetts Press, 2001.

Dudziak, Mary L. Cold War Civil Rights: Race and the Image of American Democracy. Princeton, N.J.: Princeton University Press, 2000.

Endy, Christopher. Cold War Holidays American Tourism in France. Chapel Hill: University of North Carolina Press, 2004.

Enloe, Cynthia. Bananas, Beaches, and Bases: Making Feminist Sense of International Politics. Berkley: University of California Press, 2000.

Ewing, Joseph H. 29th Infantry Division: A Short History of a Fighting Division. Paducah, KY: Turner Pub. Co, 1992.

Faust, Drew Gilpin. This Republic of Suffering: Death and the American Civil War. New York: Alfred A. Knopf, 2008.

Fenby, Jonathan. The General: Charles De Gaulle and the France He Saved. New York: Skyhorse Pub, 2012.

Fitzpatrick, Sheila. The Russian Revolution. Oxford [Oxfordshire]: Oxford University Press, 1982.

Foner, Eric. The New American History. Philadelphia: Temple University Press, 1990.

Friedman, Max Paul. Rethinking Anti-Americanism: The History of an Exceptional Concept in American Foreign Relations. Cambridge: Cambridge University Press, 2012

Fussell, Paul. The Great War and Modern Memory. New York: Oxford University Press, 1975.

Gaddis, John Lewis. Strategies of Containment: A Critical Appraisal of Postwar American National Security Policy. New York: Oxford University Press, 1982.

Greenberg, Amy S. Manifest Manhood and the Antebellum American Empire. Cambridge, UK: Cambridge University Press, 2005.

Halberstam, David. The Coldest Winter: America and the Korean War. 2007.

Hart, Justin. Empire of Ideas: The Origins of Public Diplomacy and the Transformation of U.S. Foreign Policy. Oxford: Oxford University Press, 2013.

Hemingway, Ernest. A Moveable Feast. New York: Charles Scribner's Sons, 1964. The Sun Also Rises. New York: Scribner, 1996. 
Hixson, Walter L. The Myth of American Diplomacy: National Identity and U.S. Foreign Policy. New Haven: Yale University Press, 2008.

Hobsbawm, E. J. The Age of Revolution, 1789-1848. Cleveland: World Pub. Co, 1962.

Hogan, Michael J., and Thomas G. Paterson. Explaining the History of American Foreign Relations. Cambridge: Cambridge University Press, 1991.

Hoganson, Kristin L. Consumers' Imperium: The Global Production of American Domesticity, 1865-1920. Chapel Hill: University of North Carolina Press, 2007.

Hunt, Michael H. Ideology and US Foreign Policy. New Haven u.a: Yale Univ. Pr, 1987.

Hunter, James Davison. Culture Wars: The Struggle to Define America. [New York]: BasicBooks, 1991.

Igarashi, Yoshikuni. Bodies of Memory Narratives of War in Postwar Japanese Culture, 1945-1970. Princeton, N.J.: Princeton University Press, 2000.

Iriye, Akira. The Globalizing of America, 1913-1945. New York: Cambridge University Press, 1993.

Judt, Tony. Postwar: A History of Europe Since 1945. New York: Penguin Press, 2005.

Kammen, Michael G. Mystic Chords of Memory: The Transformation of Tradition in American Culture. New York: Knopf, 1991.

Kettenacker, Lothar, and Torsten Riotte. The Legacies of Two World Wars: European Societies in the Twentieth Century. New York: Berghahn Books, 2011.

Kolko, Gabriel. The Triumph of Conservatism; A Re-Interpretation of American History, 1900-1916. [New York]: Free Press of Glencoe, 1963.

Kuisel, Richard F. Seducing the French The Dilemma of Americanization. Berkeley: University of California Press, 1993.

Laderman, Gary. The Sacred Remains American Attitudes Toward Death, 1799-1883. New Haven: Yale University Press, 1996.

LaFeber, Walter. America, Russia, and the Cold War, 1945-1966. New York: Wiley, 1967.

Lawson, R. Alan. A Commonwealth of Hope: The New Deal Response to Crisis. Baltimore: Johns Hopkins University Press, 2006. 
Leach, William. Land of Desire: Merchants, Power, and the Rise of a New American Culture. New York: Pantheon Books, 1993.

Lederer, William J., and Eugene Burdick. The Ugly American. New York: Norton, 1958.

Lengel, Edward G. To Conquer Hell: The Meuse-Argonne, 1918. New York: H. Holt, 2008.

Levenstein, Harvey A. We'll Always Have Paris American Tourists in France Since 1930. Chicago: University of Chicago Press, 2004.

Linderman, Gerald F. The World Within War: America's Combat Experience in World War II. New York: Free Press, 1997.

MacMillan, Margaret. Paris 1919: Six Months That Changed the World. New York: Random House, 2002.

Marchand, Suzanne. Down from Olympus: Archeology and Philhellenism in Germany, 1750-1970. Princeton: Princeton University Press, 1996.

Margalit, Gilad. Guilt, Suffering, and Memory: Germany Remembers Its Dead of World War II. Bloomington: Indiana University Press, 2010.

Mazower, Mark. Dark Continent: Europe's Twentieth Century. New York: A.A. Knopf, 1999.

McClellan, Andrew. Inventing the Louvre: Art, Politics, and the Origins of the Modern Museum in Eighteenth-Century Paris. Cambridge [England]: Cambridge University Press, 1994.

McMahon, Robert J. Dean Acheson and the Creation of an American World Order. Washington, D.C.: Potomac Books, 2009.

McPherson, Alan L. Yankee No! Anti-Americanism in U.S.--Latin American Relations. Cambridge, Mass: Harvard University Press, 2003.

Moeller, Robert. War Stories: The Search for a Usable Past in the Federal Republic of Germany. Berkeley: University of California Press, 2003.

Neff, John R. Honoring the Civil War Dead: Commemoration and the Problem of Reconciliation. Lawrence: University Press of Kansas, 2005.

Neustadt, Richard E., and Ernest R. May. Thinking in Time: The Uses of History for Decision-Makers. New York: Free Press, 1986. 
Ninkovich, Frank A. The Diplomacy of Ideas: U.S. Foreign Policy and Cultural Relations, 1938-1950. Cambridge [England]: Cambridge University Press, 1981.

Nora, Pierre. Rethinking France $=$ Les lieux de mémoire . Chicago: University of Chicago Press, 2001.

Novick, Peter. The Resistance Versus Vichy: The Purge of Collaborators in Liberated France. New York: Columbia University Press, 1968.

Nye, Joseph S. Soft Power: The Means to Success in World Politics. New York: Public Affairs, 2004.

Panchasi, Roxanne. Future Tense The Culture of Anticipation in France between the Wars. Ithaca, N.Y.: Cornell University Press, 2009.

Passerini, Luisa. Fascism in Popular Memory: The Cultural Experience of the Turin Working Class. Cambridge [Cambridgeshire]: Cambridge University Press, 1987.

Patterson, David S. The Search for Negotiated Peace: Women's Activism and Citizen Diplomacy in World War I. New York: Routledge, 2008.

Pells, Richard H. Not Like Us: How Europeans Have Loved, Hated, and Transformed American Culture Since World War II. New York, NY: Basic Books, 1997.

Perry, Mark. Partners in Command: George Marshall and Dwight Eisenhower in War and Peace. New York: Penguin Press, 2007.

Piehler, G. Kurt. Remembering War the American Way. Washington, D.C.: Smithsonian Institution Press, 1995.

Pogue, Forrest C. George C. Marshall, Volumes I-IV. New York: Viking Press, 1963.

Poole, Robert M. On Hallowed Ground: The Story of Arlington National Cemetery. New York, N.Y.: Walker \& Co, 2009.

Preston, Andrew. Sword of the Spirit, Shield of Faith: Religion in American War and Diplomacy. New York: Alfred A. Knopf, 2012.

Renda, Mary A. Taking Haiti: Military Occupation and the Culture of U.S. Imperialism, 1915-1940. Chapel Hill: University of North Carolina Press, 2001.

Reynolds, David. From Munich to Pearl Harbor: Roosevelt's America and the Origins of the Second World War. Chicago: Ivan R. Dee, 2001. 
Richardson, Elmo. The Presidency of Dwight D. Eisenhower. Lawrence: Regents Press of Kansas, 1979.

Robin, Ron Theodore. Enclaves of America: The Rhetoric of American Political Architecture Abroad, 1900-1965. Princeton, N.J.: Princeton University Press, 1992.

Roger, Philippe. The American enemy: a story of French anti-Americanism. Chicago: University of Chicago Press, 2005.

Rose, Kenneth D. Myth and the Greatest Generation: A Social History of Americans in World War II. New York: Routledge, 2008.

Ross, Kristin. Fast Cars, Clean Bodies Decolonization and the Reordering of French Culture. Cambridge, Mass: MIT Press, 1995.

Rothman, Hal. Devil's Bargains: Tourism in the Twentieth-Century American West. Lawrence, Kan: University Press of Kansas, 1998.

Rousso, Henry. The Vichy Syndrome: History and Memory in France Since 1944. Cambridge, Mass: Harvard University Press, 1991.

Savage, Kirk. Standing Soldiers, Kneeling Slaves: Race, War, and Monument in Nineteenth-Century America. Princeton, N.J.: Princeton University Press, 1997.

Schama, Simon. Citizens: A Chronicle of the French Revolution. New York: Knopf, 1989.

Schoenbaum, Thomas J. Waging Peace and War: Dean Rusk in the Truman, Kennedy, and Johnson Years. New York: Simon and Schuster, 1988.

Schrijvers, Peter. The Crash of Ruin: American Combat Soldiers in Europe During World War II. New York: New York University Press, 1998.

The Margraten Boys: How a European Village Kept America's Liberators Alive. Houndmills, Basingstoke, Hampshire: Palgrave Macmillan, 2012.

Shack, William A. Harlem in Montmartre: A Paris Jazz Story between the Great Wars. Berkeley: University of California Press, 2001.

Shaffer, Marguerite S. See America First: Tourism and National Identity, 1880-1940. Washington: Smithsonian Institution Press, 2001.

Singer, Daniel. Prelude to Revolution; France in May 1968. New York: Hill and Wang, 1970.

Sledge, Michael. Soldier Dead: How We Recover, Identify, Bury, and Honor Our Military Fallen. New York, Columbia University Press, 2005. 
Smythe, Donald. Pershing, General of the Armies. Bloomington: Indiana University Press, 1986.

Snell, Mark A. Unknown Soldiers: The American Expeditionary Forces in Memory and Remembrance. Kent, Ohio: Kent State University Press, 2008.

Snyder, Timothy. Bloodlands: Europe between Hitler and Stalin. New York: Basic Books, 2010.

Stephan, Alexander. The Americanization of Europe: Culture, Diplomacy, and AntiAmericanism After 1945. New York: Berghahn Books, 2006.

Americanization and Anti-Americanism: The German Encounter with American Culture After 1945. New York: Berghahn Books, 2005.

Sullivan, Marianna P. France's Vietnam Policy: A Study in French-American Relations. Westport, Conn: Greenwood Press, 1978.

Trachtenberg, Alan, and Eric Foner. The Incorporation of America: Culture and Society in the Gilded Age. New York: Hill and Wang, 1982.

Trouillot, Michel-Rolph. Silencing the Past: Power and the Production of History. Boston, Mass: Beacon Press, 1995.

Trout, Steven. On the Battlefield of Memory: The First World War and American Remembrance, 1919-1941 (2010).

Tuchman, Barbara W. The Guns of August. New York: Macmillan, 1962.

Verdery, Katherine. The Political lives of Dead Bodies: Reburial and Postsocialist Change. New York: Columbia University Press, 1999.

Wagnleitner,Reinhold. Coca-colonization and the Cold War the Cultural Mission of the United States in Austria After the Second World War. Chapel Hill: University of North Carolina Press, 1994.

Weber, Eugen. Peasants into Frenchmen: The Modernization of Rural France, 18701914. Stanford, Calif: Stanford University Press, 1976.

Westad, Odd Arne. The Global Cold War: Third World Interventions and the Making of Our Times. Cambridge: Cambridge University Press, 2005.

Winter, Jay. Sites of Memory, Sites of Mourning: The Great War in European Cultural History. Cambridge University Press, 1995. 
Zubok, V. M. A Failed Empire: The Soviet Union in the Cold War from Stalin to Gorbachev. Chapel Hill: University of North Carolina Press, 2007.

\section{Unpublished Theses and Papers}

Finkelstein, Allison. "The Gold Star Pilgrimage Rest Houses of 1930-1933: Ephemeral Vernacular Buildings on the Landscape of American Military Memory.” Pending Publishing, 2015.

Hulver, Richard. Ezra Carman: The Gatekeeper of Memory at Antietam National Battlefield. West Virginia University, WVU Library M.A. Thesis, 2009.

North, Thomas. One Soldier's Story. Arlington, VA: ABMC Office Archives, unpublished, undated.

Seitz, David W. Grave Negotiations: The Rhetorical Foundation of American World War I Cemeteries in Europe. University of Pittsburgh, 2011. 
